
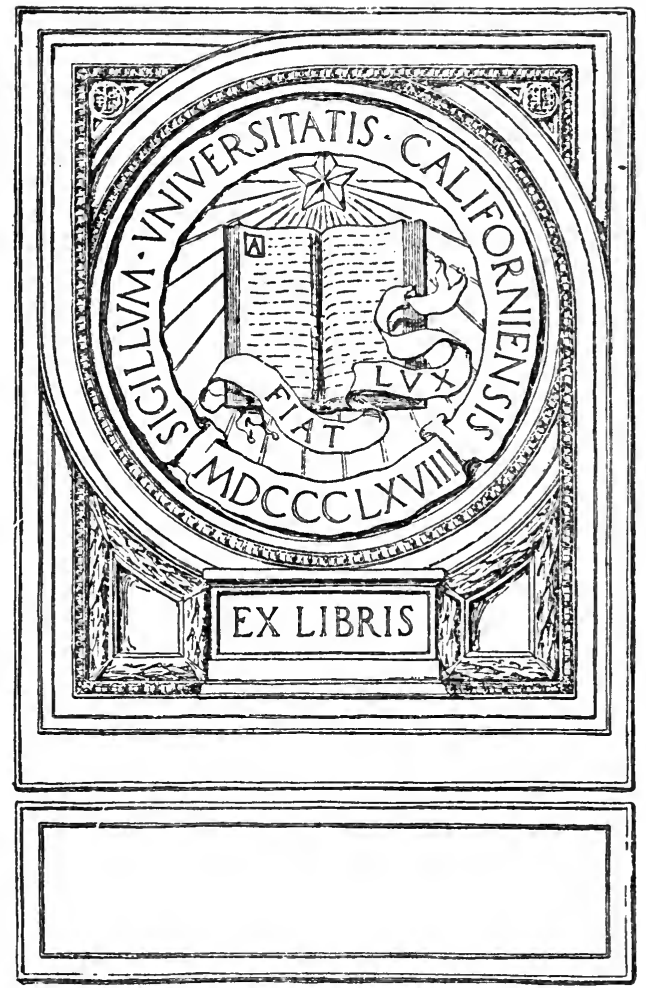

Digitized by the Internet Archive in 2007 with funding from

Microsoft Corporation 


\section{WHAT SCULPTURE TO SEE IN EUROPE}




\section{BY THE SAME AUTHOR}

PICTURES AND THEIR PAINTERS

The History of Painting. With 300 Illustrations. $8 \mathrm{vo} . \$ 2.50$ net.

WHAT PICTURES TO SEE IN EUROPE IN ONE SUMMER. Illustrated. $12 \mathrm{mo} . \$ 1.35$ net.

FAMOUS PICTURES OF REAL BOYS AND GIRLS. Over 50 Illustrations. $12 \mathrm{mo}$. $\$ 1.25$ net. 



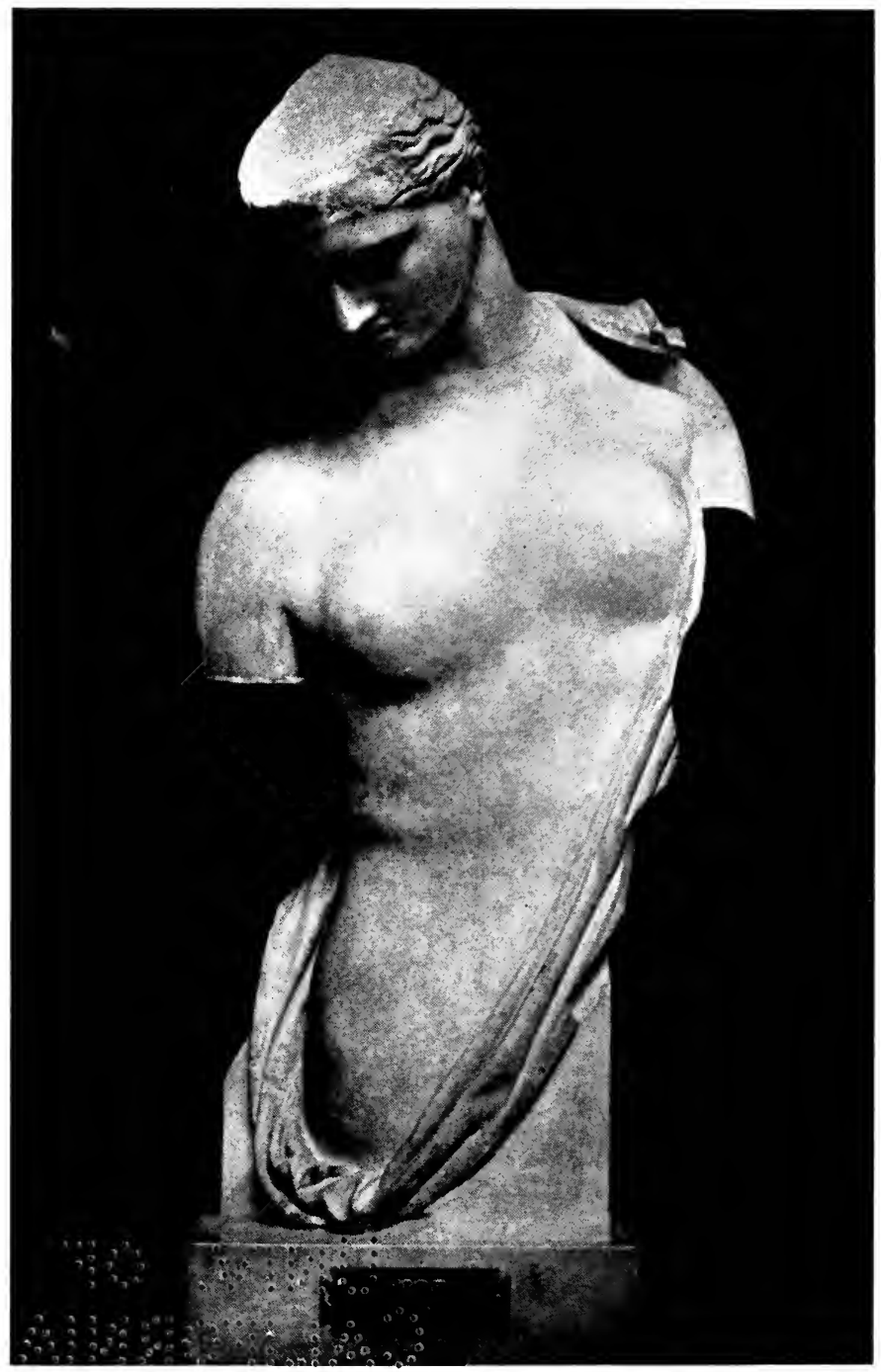

Photograph by Gaetano Pedo, Rome

Psyche. Copy of Praxiteles. Museum, Naples. 


\section{WHAT SCULPTURE TO SEE IN EUROPE}

BY LORINDA MUNSON BRYANT

WITH OVER 150 ILLUSTRATIONS

LONDON : JOHN LANE, THE BODLEY HEAD NEW YORK : JOHN LANE COMPANY MCMXX 


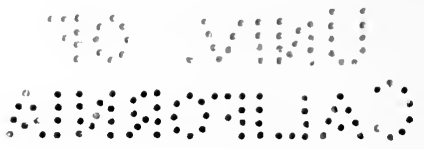

Copyright, 1914, By JOHN LANB COMPANY

PUBLISHERS PRINTING COMPANY 207-217 West Twenty-fifth St., New York 


\section{TO \\ THE MEMORY \\ OF MY \\ MOTHER AND FATHER}




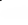




\section{INTRODUCTION}

POSSIBLY there are no collections of art in 1 Europe where the general tourist needs more careful guiding than in the sculpture galleries. This is due first, to the fragmentary nature of the specimens of antique sculpture, and, second, to the fact that very few of the fragments are originals of the great masters of the past.

Then, too, the general tourist in a sculpture gallery gives very little thought to the marred and broken pieces of marble, however rare the workmanship, unless special points of value are brought to the attention or some hint given as to their meaning and purpose.

My aim in this book is to arouse an interest in masterpieces even if broken by the despoiler or marred by the restorer. To accomplish this I have given occasionally the historical setting of some pieces and the mythological story of others; such as the special prowess of some great man or the sublime power of a Roman matron; the biblical account of a lawgiver or the tender beauty of singing children.

In discussing the various galleries I have referred here and there to isolated statues which are sep- 


\section{INTRODUCTION}

arated from their original groups, hoping thus to present to the tourist a complete whole of the artist's conception and give him a better understanding of the great masters.

No attempt of course has been made to cover all the masterpieces, but simply to designate a few so that the tourist may see the best and obtain a working basis for further study at home and abroad. 


\section{CONTENTS}

CHAPTER

PAGE

I. Naples

II. Naples (continued) . . . . . 30

III. Rome-Vatican . • . . . . 42

IV. Rome-Vatican (continued) . . $\quad 52$

V. Rome-Capitoline Museum . . . 63

VI. Rome-National Museum . . . 70

VII. Rome-Miscellaneous . • . . 77

VIII. Florence-Uffizi Gallery • • . . 85

IX. Florence-Michael Angelo . . . 94 X. Florence-Bargello . . . . . 100

XI. Florence-Miscellaneous . . . 107

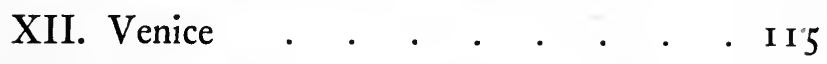

XIII. Munich • • • . . • . . 124

XIV. Berlin . • • • . . . . . $\quad$. $\mathbf{I} 34$

XV. Paris-Louvre . . . . . . 144

XVI. Paris-Louvre (continued) . . . I 5 I 


\section{CONTENTS}

CHAPTER

PAGE

XVII. Paris-Louvre (concluded) . . I60

XVIII. Paris-Miscellaneous . . . . . 169

XIX. London-British Museum . . . I77

XX. London-Ancient Sculpture, British

Museum (continued) . . . 187

XXI. London-British Museum, Egyptian and Assyrian Sculpture . . 196

L'EnvoI . . . . . . . . 206

INDEX . . $\quad \cdot \quad \cdot \quad \cdot \quad \cdot \quad \cdot 207$

[ 10 ] 


\section{ILLUSTRATIONS}

Psyche (Frontispiece). Copy of Praxiteles. Museum, Naples.

FIG.

1.-Aphrodite (Venus) of Capua. Museum, Naples . . . . . . . 26

2.-Farnese Flora. Museum, Naples . . . 26

3.-Hermes in Repose. From Herculaneum. Museum, Naples . . . . . 27

4.-Narcissus Listening. Museum, Naples . . 27

5.-Bust of Dionysos. Museum, Naples . . 30

6.-The Dead Amazon. Museum, Naples . . 30

7.-Archaistic Pallas Athena. Museum, Naples 31

8.-The Farnese Bull. By Apollonios and Tauriscos of Tralles. Museum, Naples . . 31

9.-The Farnese Hercules. By Glycon the Athenian. Museum, Naples . . . . 36

10.-Homer. Museum, Naples . . . . 36

11.-Harmodios and Aristogeiton. Museum, Naples . . . . . . . 36

12.-Apollo Belvedere. Vatican, Rome . . 42

13.-Aphrodite (Venus) of Cnidus. (From an undraped cast.) . . . . . . 43

14.-Aphrodite (Venus) of Cnidus (draped).

After Praxiteles. Vatican, Rome . . 43

15.-Eros from Centocelle. Vatican, Rome . . 43

\section{[ I I ]}




\section{ILLUSTRATIONS}

FIG.

16.-Apollo Sauroktonos. Vatican, Rome . . 46

17.-Pallas Athena. Vatican, Rome . . . 46

18.-Zeus Otriculi. Vatican, Rome . . . 47

19.-Meleager and Boar Head. Vatican, Rome . 47

20.-Torso del Belvedere. Vatican, Rome . . 52

21.-Discus Thrower, after Myron. Vatican,

Rome . . . . . . . . 52

22.-Discus Thrower. Palazzi Lancellotti, Rome 52

23.-Ganymede and the Eagle. Vatican, Rome - 53

24.-Ariadne. Vatican, Rome . . . . 53

25.-Laocoön. Vatican, Rome . . . . 58

26.-Boy with Goose, after Böethos. Vatican,

Rome . . . . . . $\quad . \quad 58$

27.-Nile. Vatican, Rome . . . . . 58

28.-Demosthenes. Vatican, Rome . . . 59

29.-Augustus Cæsar. Vatican, Rome . . 59

30.-Equestrian Statue of Marcus Aurelius. Piazzi

del Campidoglio, Rome . . . . 62

31.-Dying Gaul. Capitoline, Rome . . . 62

32.-Satyr, "Marble Faun," after Praxiteles. Capitoline, Rome . . . . . . . 63

33.-Capitoline Aphrodite. Capitoline, Rome . 63

34.-Endymion. Capitoline, Rome . . . 68

35.-The Wolf. Capitoline, Rome . . 68

36.-Socrates. Capitoline, Rome . • . . 69

37.-Seated Woman, "Agrippina," Capitoline,

Rome . . . . . . 69 


\section{ILLUSTRATIONS}

FIG.

38. - The Birth of Aphrodite (Venus). National Museum, Rome . . . . . 72

39.-Medusa Head. National Museum, Rome . 72

40.-Galatian Warrior and his Dying Wife. National Museum, Rome . . . . 73

41.-Ares Ludovisi. National Museum, Rome . 73

42.-Hera (Juno) Ludovisi. National Museum, Rome . . . . . . . . 76

43.-Bronze Pugilist. National Museum, Rome . 76 44.-Kneeling Youth from Subiaco. National Museum, Rome . . . . . . 76

45.-Moses. By Michael Angelo. S. Pietro in Vincoli, Rome . $\quad$ • . $\quad$ • $\quad$. 77 46.-Pietà. Michael Angelo (1475-1564). St. Peter's, Rome . . . . . . 80

47.-Christ on the Cross. By Michael Angelo. S. Maria sopra Minerva, Rome . . . 80 48.-The Seven Branched Candlesticks. Arch of Titus, Rome . $\quad . \quad$. $\quad$ • $\quad$. 81 49.-Relief of Pig, Sheep and Bull. Roman Forum, Rome . . . . . . . . . 81 50.-The Prefect. Roman Forum, Rome - $\quad 84$ 51.-Marsyas. Lateran, Rome . . . 84 52.-Sophocles. Lateran, Rome . . . 84 53.-Niobe and her Daughter. Uffizi, Florence . 85 54.-Fleeing Son of Niobe. Uffizi, Florence . 85 55.-Pædagog (Niobe Group). Uffizi, Florence 88 


\section{ILLUSTRATIONS}

FIG.

56.-Venus de' Medici. Uffizi, Florence . . 88

57.-The Wrestlers. Uffizi, Florence . . . 89

58.-Slave Sharpening a Knife. Uffizi, Florence . 89

59.-Dog. Uffizi, Florence . . . . . 92

60.-Perseus with the Head of Medusa. Benven-

uto Cellini (1500-1570). Piazza della

Signoria, Florence . • • • . 96

61.-David. Michael Angelo. Academy, Flor-

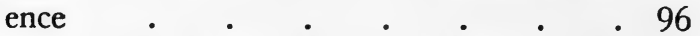

62. - Tomb of Giuliano de' Medici. Michael Angelo. New Sacristy, S. Lorenzo, Florence 96 63.-Night (detail). Michael Angelo. New Sacristy, S. Lorenzo, Florence - . 97

64.-Lorenzo de' Medici (detail). Michael Angelo. New Sacristy, S. Lorenzo, Florence 98 65.-Drunken Bacchus. Michael Angelo. Bargello, Florence . $\quad$. $\quad$ • 98 66.-Saint George. Donatello (1386-1466). Bargello, Florence . . . . 100

67.-David. Donatello. Bargello, Florence . 100 68.-David. Verrocchio (1435-1488). Bargello,

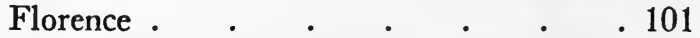

69.-Mercury. Giovanni da Bologna (1524-1608).

Bargello . . . . . . . 101

70.-The Sacrifice of Abraham. Brunelleschi

(1377-1446). Bargello, Florence . . 106

71. - The Sacrifice of Abraham. Ghiberti (1378-

1455). Bargello, Florence . . . 106

$$
\text { [ } 14 \text { ] }
$$




\section{ILLUSTRATIONS}

FIG.

PAGE

72.-The Story of Abraham (Fourth Panel).

Ghiberti. East Doors, Baptistry Gates,

Florence . . . . . . . 107

73. - The Story of Cain and Abel (Second Panel).

Ghiberti. East Doors, Paptistry Gates,

Florence . . . . . . . 107

74.-Zacharias Naming the Little St. John. Andrea Pisano (1270-1345). South Doors, Baptistry, Florence . . . . . 110

75.-Jubal at Tent Door. Giotto, Campanile, Florence .

76.-Singing Boys (Lower Panel). Donatello.

Cathedral Museum, Florence . . . 111

77.-_Singing Boys (Lower Panel). Luca della Robbia (1399-1482). Cathedral Museum,

Florence . . . . . . . . 111

78.-Bambino. Andrea della Robbia (1435-1525).

Innocenti, Florence . . . . 114

79.-Boy with Dolphin. Verrocchio. Palazzo Vec-

chio, Florence. . . . . . 114

80.-Bronze Horses. St. Mark's Cathedral, Venice 115

81.-Statue of Bartolomeo Colleoni. Verrocchio.

Piazzi of San Giovanni e Paolo, Venice . 120

82.-Mercury. Jacopo Sansovino (1487-1570).

Loggietta, Campanile, Venice . $\quad$. 120

83.-Lion of St. Mark. Column in Piazzetta, Ven-

ice . $. \quad . \quad . \quad . \quad . \quad . \quad .120$

84.-Adam and Eve. Doge's Palace, Venice . . 121 


\section{ILLUSTRATIONS}

FIG.

85.-Greek Lion. Arsenal, Venice

86.-Athena and Warriors. East Pediment, Temple of Aigina. Glyptothek, Munich . . 128

87.-Fallen Warrior. West Pediment, Temple of Aigina. Glyptothek, Munich . . 128 88.-Dying Niobid. Glyptothek, Munich . . 128 89._-"Ilioneus" (Niobid). Glyptothek, Munich . 129 90.-Medusa Rondanni. Glyptothek, Munich . 129 91.-Eirene and Plutus. After Cephisdotus. Glyptothek, Munich . . . . . 130

92.--Silenos and Infant Dionysos. Glyptothek, Munich . . . . . . . 130

93.-Athlete Dropping Oil into his Hand. Glyptothek, Munich . . . . . 131

94.-Satyr, "Barberini Faun." Glyptothek, Munich . . . . . . . 131

95.-Boy with Goose. After Böethos. Glyptothek, Munich . . . . . . . 132

96.-Selene. Pergamon Marbles. Pergamon $\mathrm{Mu}$ seum, Berlin . . . . . . 136

97.-Dionysos. Pergamon Museum, Berlin . . 136 98.-Bust of Aphrodite. Pergamon Museum, Berlin . . . . . . . . 137

99.-Athena, Pergamon Copy. Pergamon Museum, Berlin . . . . . . 140

100.-Amazon. After Polycletos. Old Museum, Berlin . . . . . . . 140 101.-Boy Praying. Antiquarium, Berlin . . 141 [ I6] 


\section{ILLUSTRATIONS}

FIG.

PAGE

102.-Boy Found in the Rhine. Antiquarium, Berlin .

. 141

103.-Victory of Samothrace. Louvre, Paris . $\quad 144$ 104.-Venus de Milo. Louvre, Paris . . 145 105.-Aphrodite of Arles. Louvre, Paris • 148 106.- “Apollo," Sauroktonos. Louvre, Paris . 148 107.-Athena of Velletri. Louvre, Paris . . 149 108.-Aphrodite, "Venus Genetrix." Louvre, Paris 149 109.-Warrior Borghese. Louvre, Paris . . 150 110.-Marsyas. Louvre, Paris . . . 150

111.-Artemis of Versailles. Louvre, Paris . . 151 112.-Torso of Satyr. Copy of Praxiteles. Louvre, Paris . . . . . . . 151

113.-Medusa Head. Louvre, Paris . . 152 114.-Pædagog and Boy (Niobid). Louvre, Paris 152 115.-Ares, "Borghese Mars." Louvre, Paris . 153 116.-Silenos and Infant Dionysos. Louvre, Paris 153 117.-Hera (Juno) of Samos. Louvre, Paris . 153 118.-Relief from Thasos. Louvre, Paris . . 156 119.-Maidens from East Frieze of Parthenon. Louvre, Paris . . . . . 156 120.-Dying Slave. Michael Angelo. Louvre, Paris . . . . . . 160

121.-Fettered Slave. Michael Angelo. Louvre, Paris . . . . . . 160 122.-Julius Cæsar. Attributed to Donatello. Louvre, Paris . . . . . . 161 [ I7 ] 


\section{ILLUSTRATIONS}

FIG.

123.-Le Scribe. Louvre, Paris . . . . 161

124.-Cupid and Psyche. Canova. Louvre, Paris . 162

125.-Joan of Arc. François Rude (1784-1855).

Louvre, Paris . . . . . 162

126.-Joan of Arc. Henri Chapu (1833-1891).

Louvre, Paris . . . . . 168

127.-Centaur and Lapith. Antoine Louis Barye

(1795-1875). Louvre, Paris . . . 168

128.-The Lion and the Serpent, Antoine Louis

Barye. The Tuileries Gardens, Paris . 169

129.-Florentine Singer. Paul Dubois (1829-?).

Luxembourg, Paris . . . . 169

130.-Genius Guarding the Secret of the Tomb.

Saint-Marceaux (18-). Luxembourg,

Paris . . . . . . . 172

131. - John the Baptist. August Rodin (1840-).

Luxembourg, Paris . . . . 172

132.-The Thinker. Auguste Rodin. The Pantheon,

Paris . . . . . . . 173

133.-Gargoyle Guarding Paris. Notre-Dame, Paris 173

134.-Athena Medici. Ecole des Beaux Arts, Paris 176

135.-Le Monument des Morts. By Albert Bar-

tholomé. Père-Lachaise Cemetery, Paris . 176

136.-Demeter of Cnidus. British Museum, London 177

137.-Thanetos, Alcestis, and Hermes. Drum of

Column from Ephesus. British Museum,

London .

$$
\text { [ } 18 \text { ] }
$$




\section{ILLUSTRATIONS}

FIG.

PAGE

138. - Three Fates (?). East Pediment of Parthenon. British Museum, London . 182

139.-Theseus. East Pediment from Parthenon. British Museum, London . . . 183

140.-Cephissus. West Pediment from Parthenon. British Museum, London . . 183

141.-Procession of Youths. North Frieze from Parthenon. British Museum, London . 186 142.-Centaur with Lapith Woman. Metope from Parthenon. British Museum, London . 186

143.-Lapith Attacking Centaur. Metope from Parthenon. British Museum, London . 186 144.-Caryatid. From Erechtheion, Athens. British Museum, London . . . . 187

145.-Mausolos. From Mausoleum at Halicarnassos. British Museum, London

146.-Amazons Fighting. Mausoleum Frieze. British Museum, London . . . 190

147.-Charioteer from Small Frieze. British Museum, London . . . . $\quad$. 190

148.-Nereid or Sea-Nymph from Xanthos. British Museum, London . . . . 190

149.-Frieze of the "Harpy" Tomb. British Museum, London . $\quad$ • $\quad$. $\quad$. 191

150.-Frieze of Cock and Hens from Xanthos.

British Museum, London . . . 191

151.-Marsyas. British Museum, London . 194 


\section{ILLUSTRATIONS}

FIG.

PAGE

152.-Boy Extracting Thorn from his Foot. British Museum, London . . . . 194

153.-Thothmes III., Eighteenth Dynasty (about B.c. 1550), Egypt. British Museum, London . . . . . . . . 202

154.-Rameses II., Nineteenth Dynasty (в.c. 13331300), Egypt. British Museum, London . 202 155.-Ashur-nasir-pal (в.c. 885), Assyria. British Museum, London . . . . . 203 156.-Colossal Lion. Assyria. British Museum, London . . . . . . . 203 157.-Assyrian Lioness. From Palace at Nineveh. British Museum, London . . . 206 158.-Lion. By Landseer. Trafalgar Square, London . 


\section{CHAPTER I}

\section{NAPLES}

THE Museum of Naples is one of the very best

1 in which to begin the study of sculpture, for in it are found fine specimens of almost every age of plastic art. There are some of the rarest bits of Pergamon work, of ancient Greek work and of the exquisite bronze work, the latter preserved under the lava and ashes of Herculaneum and Pompeii. In fact, two hours spent on the typical statues in the Naples Museum ought to waken the interest of the general tourist in sculpture and make him eager to follow up the study in the other European galleries.

One of the daintiest fragments of all ancient art is that of "Psyche" (frontispiece), in the Naples Museum. It is possibly an original by Praxiteles, and, if it is, we are specially grateful that the restorer has kept his hands off. If masters, such as Michael Angelo or Rodin, would consent to restore statues that time and vandalism have destroyed a new value would be added to originals, but unfortunately only men who fear not to tread where angels trod are willing to lay profane hands 


\section{WHAT SCULPTURE TO SEE}

on priceiess treasures. "Again let us be glad that "Psyche of Capua" has been left just as it was found-a fragment of beauty.

Never has Psyche, as typifying "the human soul," been portrayed with greater charm than in this exquisite bit of broken marble. The gentle submission in the bowed head of the tortured goddess, combined with her subtle beauty of face and form, remind one of the torments of a penitent soul.

Poor Psyche, her marvellous beauty was. indeed her undoing! She was the youngest of three daughters of a certain king and queen, and was so beautiful that even Venus was envious. In her anger the goddess of beauty determined to punish Psyche for her presumption-how dare a mortal vie with an immortal in beauty! But Venus was not overwise in her anger, for she sent her son Cupid-the mischievous elf-to inflict the punishment. But when Cupid saw Psyche, instead of obeying his mother's commands to smite her with a love for some one far beneath her, he wounded himself with his own arrows and determined to wed the maiden, though she were a mortal. He put his wits to work and with the help of Zephyr and his own power of being invisible, he overcame all obstacles and soon had his beloved in a magnificent palace on a mountain-top. Here all went well for a time, but at last Psyche could not be satisfied, 


\section{NAPLES}

though every wish was gratified, save that of seeing her husband with her natural eyes. Her sisters, who were brought to her palace by Zephyr, were envious and insisted that Psyche tell how her husband looked, until finally she confessed that she had never seen him. Then they poisoned her mind with outrageous tales how that an oracle had said her husband was to be a terrible monster who finally would eat her. They advised that she secrete a sharp knife and a lamp, and that when her husband was asleep she might light her lamp and see the monster herself, and then cut off his head. After the sisters were gone home Psyche was so filled with curiosity that she decided to carry out their directions. But when she leaned over to look at her husband, in her surprise at his beauty she let the hot oil from her lamp fall on his shoulder. Cupid opened his eyes and fixed them on her, then, without a word, flew out of the window. Psyche tried to follow but only fell in the dust. Cupid stopped long enough to say:

"O foolish Psyche, is it thus you repay my love? After having disobeyed my mother's commands and made you my wife will you think me a monster and cut off my head? But go; return to your sisters whose advice you seem to think preferable to mine. I inflict no other punishment than to leave you forever. Love cannot abide with suspicion." It was foolish Psyche, indeed! She wandered for

$$
\text { [23] }
$$




\section{WHAT SCULPTURE TO SEE}

years performing all sorts of impossible deeds at the bidding of Venus, the outraged goddess and indignant mother, but at last through the intercession of the almighty Zeus, Venus forgave the presumptuous maiden, and Zeus, handing her a cup of Ambrosia, said:

"Drink this Psyche, and be immortal; nor shall Cupid ever break away from the knot in which he is tied, but these nuptials shall be perpetual." The story of Cupid and Psyche dates from the second century of our era. Keats says :

\section{"O latest born and loveliest vision far Of all Olympus' faded hierarchy."}

In the same room with "Psyche" is "Aphrodite (Venus) of Capua" (Fig. I), a statue made after an original of the fifth century B. C. (Aphrodite is the Greek name and Venus the Roman name of the goddess of beauty and love.) The arms, nose and part of the mantle are modern, so it is doubtful if the restoration, especially in the position of the arms, shows the statue as it was originally. There is here the same criticism about the security of the drapery, without the right hand grasping it, that applies to the Louvre statue. The pose of the "Aphrodite of Capua" is much like the "Venus de Milo" (see Fig. I04).

The sculptor has here crowned Aphrodite with Juno's diadem and placed Athena's helmet under

$$
\text { [24] }
$$




\section{NAPLES}

her left foot as evidence that the goddess of beauty and love dared take precedence over the queen of the gods and the goddess of wisdom. It is possible that Aphrodite had some cause for her audacity for, one time at least, Athena showed lack of wisdom and Juno of dignity. It was in this wise: All the gods were invited to the wedding of Peleus and Thetis except Discord. The latter was so angry at this slight that in spite she threw a golden apple among the guests on which was written, "For the Fairest." Immediately Juno, Athena and Aphrodite each claimed it. Zeus was too wise to try to decide the matter, so he sent the three contestants to Paris, the beautiful shepherd boy on Mount Ida. When the goddesses came before him they each offered him gifts :- Juno, power and riches; Athena, glory and renown in war; and Aphrodite, the fairest of women for his wife. Paris gave Aphrodite the golden apple-and thus began the Trojan war!

The "Torso of Aphrodite" is another fragment of Greek original work of about the fourth century B. C. Possibly it was done during the time of the famous Cnidian Aphrodite of Praxiteles (see page 44).

The "Farnese Flora," more correctly Aphrodite (Fig. 2), found in the Baths of Caracalla, Rome, is in an original Greek work. The torso of the statue no doubt dates from the fourth century B. C.,

$$
\text { [25] }
$$




\section{WHAT SCULPTURE TO SEE}

but the head, arms and feet were restored by artists of the sixteenth century and probably it was then changed to represent the goddess Flora. Nothing could be finer than the proportions of the beautiful body under the clinging transparent robe. The muscles fairly quiver, they are so alive with the pulsing blood hidden under the velvety skin.

The collection of bronzes in the Naples Museum is the finest in the world. Those from Herculaneum-a large proportion is from that cityhave the same rich, dark black-green colour that they had when buried nearly two thousand years ago; while those from Pompeii are a light bluishgreen. This colour variation is probably due to the fact that the former city was buried under mud (?) and lava, and the latter under a light ash deposit.

The statue of "Hermes (Mercury) in Repose" (Fig. 3) is considered one of the most celebrated bronze statues of antiquity. It belongs to the school of Lysippus of the fourth century B. C. The rich dark colour of the bronze enhances the beauty of the firm slender limbs and compact body. There is not an ounce of superfluous flesh on the supple muscles and the perfect proportion of every muscle, tendon and joint tells the story that this god is the messenger par excellence. How restfully at rest is the whole body of the god and yet how quickly he would spring into action! Notice

$$
\text { [26] }
$$



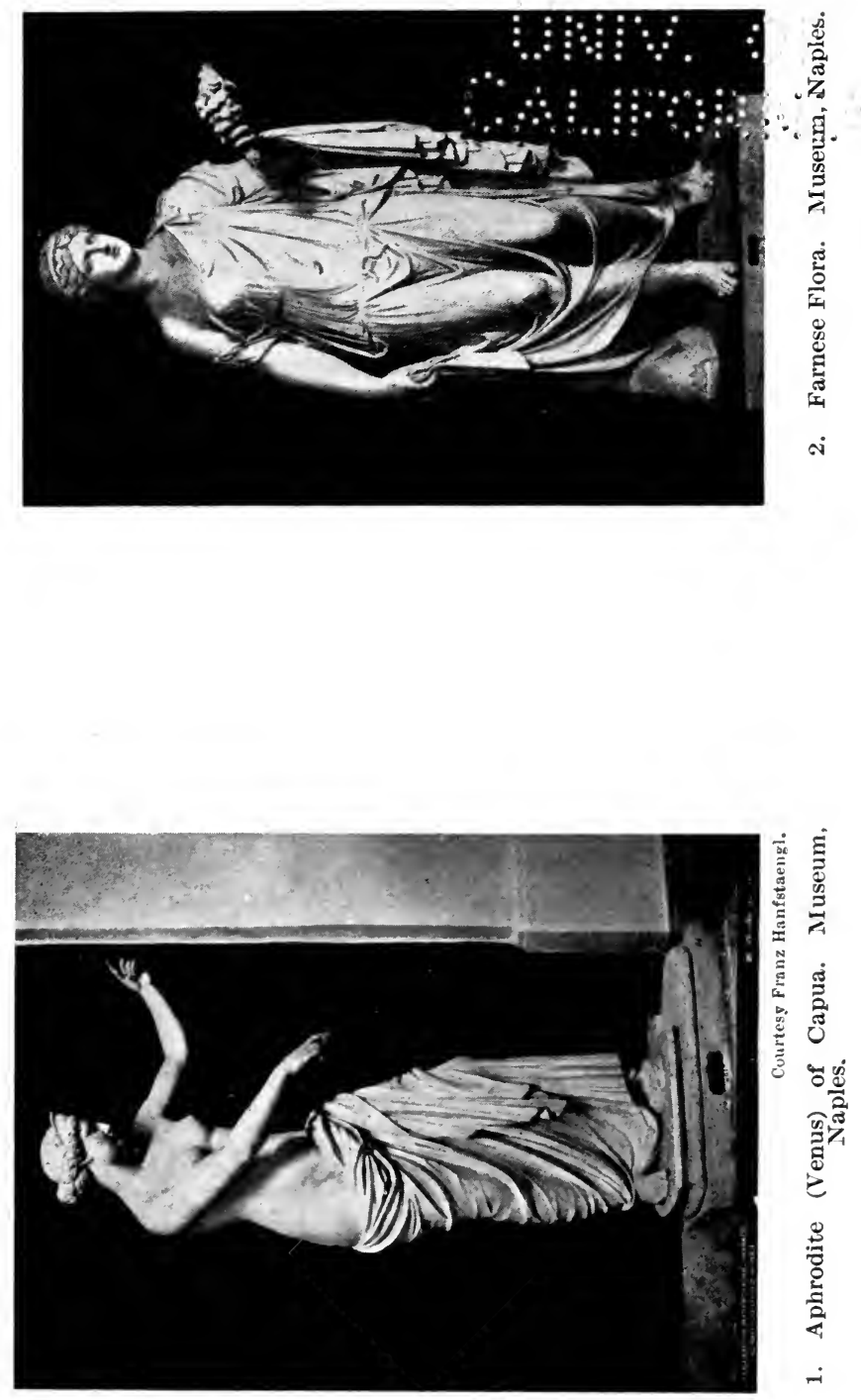

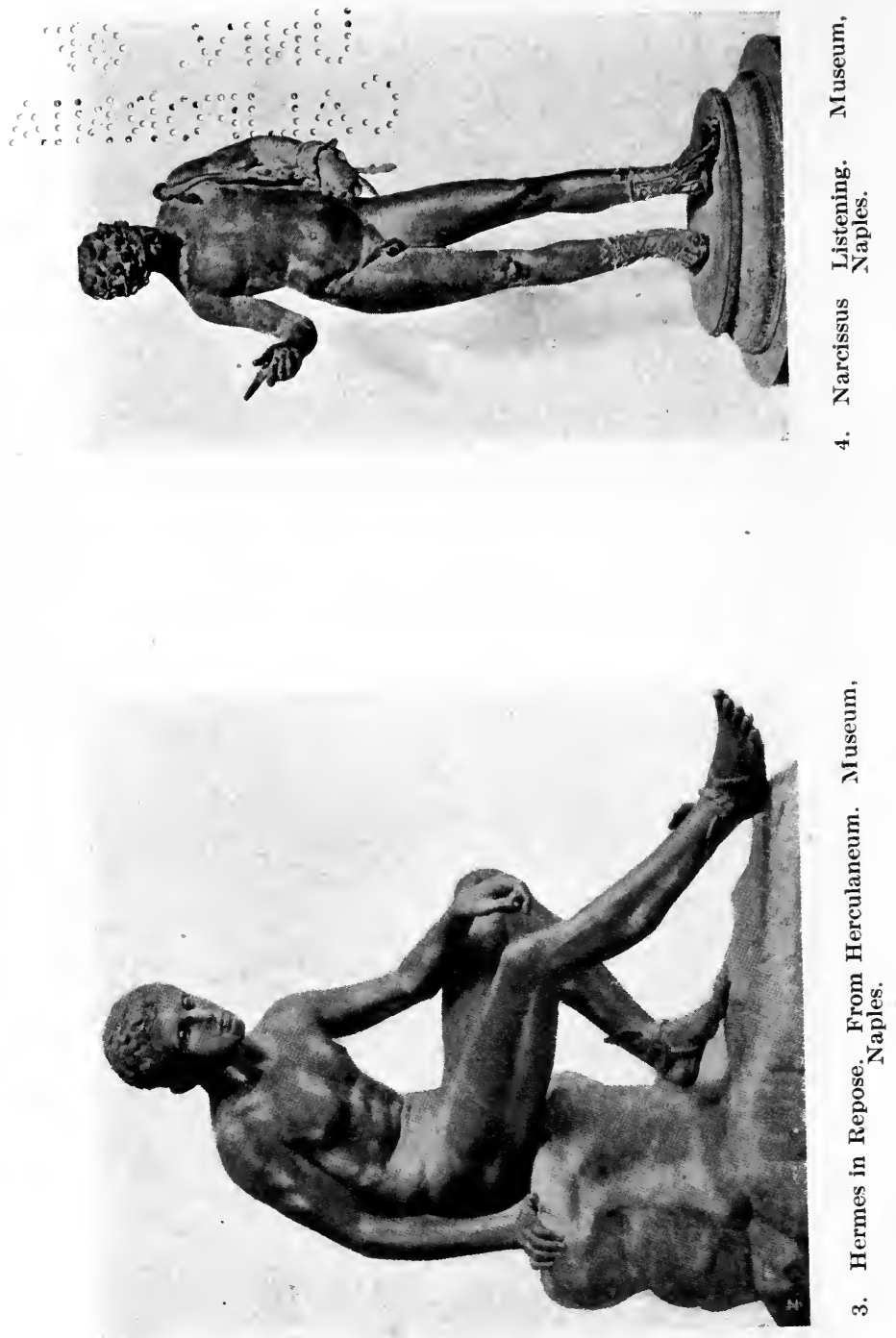


\section{NAPLES}

that the winged shoes have the buckles on the bottom of the feet, for Mercury never walked, but ran on his toes, if he was not gliding through the air.

The missions performed by this god were many and varied. As he now sits resting he is probably just returned from cutting off the head of Argus. You may remember that as usual Juno was jealous of her husband Zeus, and with some reason, for he had been flirting with Io, and, to conceal his flirtations from his watchful spouse, changed the beautiful Io into a heifer. But Juno was not to be deceived; she began at once to admire the beautiful animal and insisted on having it as her own. Of course Zeus could not refuse and Juno then put the unfortunate Io under the care of the hundred eyed Argus. Zeus, in his distress, sent his son, Mercury, to kill Argus. Mercury not only put on his winged shoes but his winged cap and carried his caduceus, a rod entwined with two serpents and used to produce sleep. Now Argus never slept with more than two eyes at a time, so he watched the heifer day and night. When Argus saw Mercury coming, as a young shepherd blowing his pipes, he asked him to stay with him. This was the god's opportunity; he made music, and told stories until at last Argus went to sleep with all his eyes and when his head fell forward Mercury cut it off with one stroke and sent it rolling down the rocks. Juno put the eyes 


\section{WHAT SCULPTURE TO SEE}

on the tail of her peacock-and there they are today.

The statue of "Narcissus" (Fig. 4) is another ancient bronze of rare excellence. The god stands in an easy listening attitude all untroubled by any longings of love. How beautiful is his face and form! how cruel his attitude as he mocks the timid Echo! and how just was his punishment! We see him moving along gaily when, missing his companions, he stops, he calls, "Who's there?" then listens to the answer, "Here," which comes back to him, but no one appears. Again he calls, "Come!" But the answer "Come!" brings no one. Narcissus is curious. $\mathrm{He}$ shouts, but his question is simply repeated. This is too much for his curiosity, he must have more than a voice, so he urged, "Let us join one another." Timid Echo came closer, but when Narcissus saw her-the maiden doomed to speak in answer only-he scorned her advances. She, poor thing, withdrew into the deep recesses of the wood, pined away and died. Now only a faint voice lingers to remind us of the maiden who insisted on the last word. But Echo's one wish, that Narcissus himself should feel the pangs of unrequited love, was fulfilled, for later he fell in love with his own image as seen in a clear mountain stream, and he, too, died of a broken heart, and the dainty Narcissus flower is the reminder of his fate. 


\section{NAPLES}

The bust of "Dionysos" (Fig. 5) was for a long time thought to be that of Plato until a genuine portrait bust was found of that philosopher. This is a bronze masterpiece of the bearded Indian Dionysos or Bacchus, the legendary founder of the Satyric drama and known as early as the sixth century B. C. The bronze head was found at Herculaneum. There is no finer piece of bronze work extant. Every detail has been worked out, but with no detriment to the big and noble conception of the god as a man of power. Dionysos, the son of Zeus and Semele, was not only the god of wine but he promoted civilisation, made laws and loved peace. The old artists always represented him as a manly man with a full beard and full of dignity. It was only when wine began to mean hilarity and unseemly conduct that Dionysos became the uncontrolled Bacchus with his disregard of law and order. 


\section{CHAPTER II \\ NAPLES (Continued)}

$W^{E}$ will now go to the small room devoted to four little recumbent statues of the school of Pergamon, to see "The Dead Amazon" (Fig. 6), a figure of surpassing grace and beauty. These small statues, three feet in length, are a part of a gift sent by King Attalus of Pergamon to the Athenians after his victory over the Gauls in 239 B. C. There were four groups of these marble statues set up on the south wall of the Acropolis, Athens, representing the power of mind over brute force. Pausanias describes them as: first, the contest of the gods and giants; second, the Athenians and the Amazons; third, the Athenians and the Persians at Marathon; and last, Attala and the Celts.

These small statues, in Asia Minor marble, are without doubt copies of older bronze works, for their smooth surface and sharply defined folds and hair, as well as their small size, indicate a metal original. It is probable that the marble copies were made in Asia Minor for exportation, but so far no bronze originals have been found in the exca- 


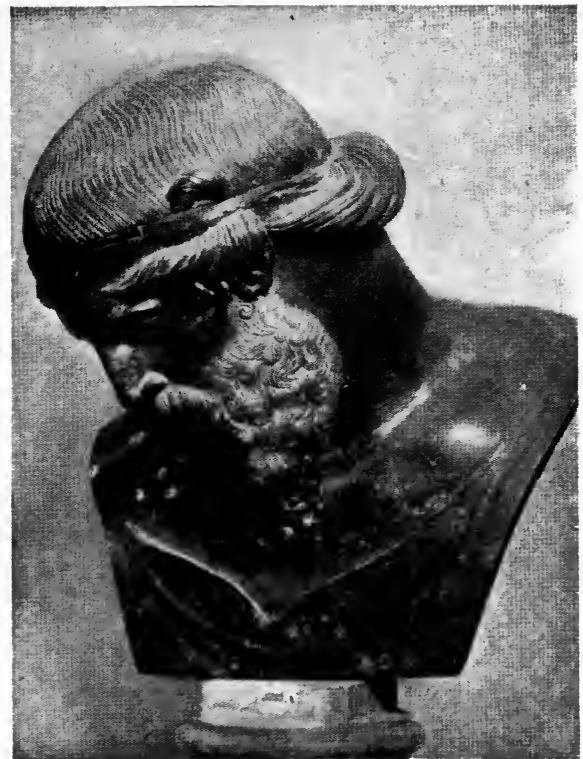

5. Bust of Dionysos. ¿ Museum, Naples.

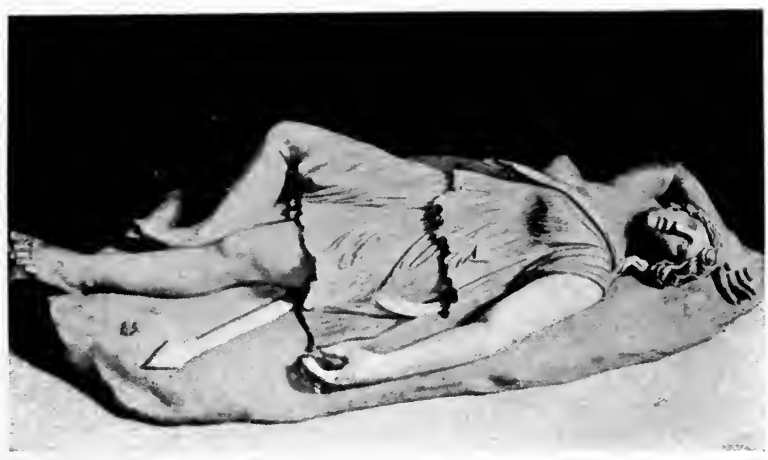

6. The Dead Amazon. Museum, Naples. 


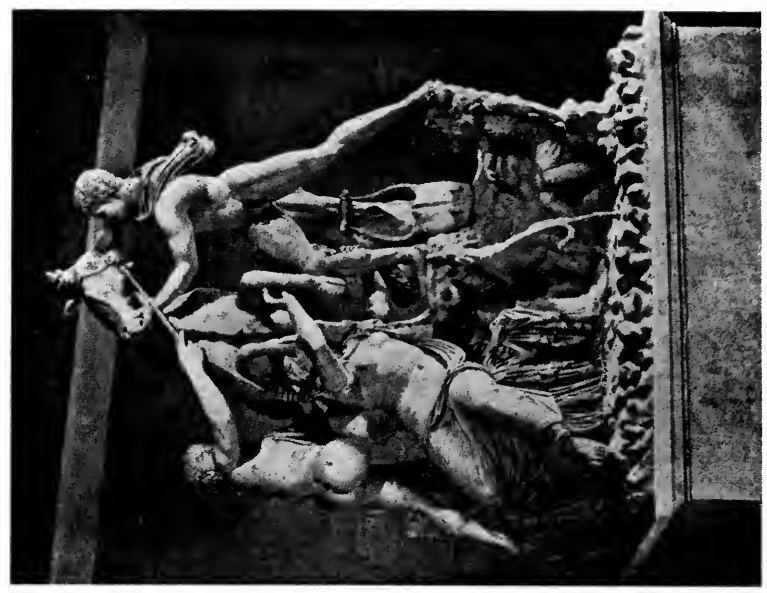

चีं

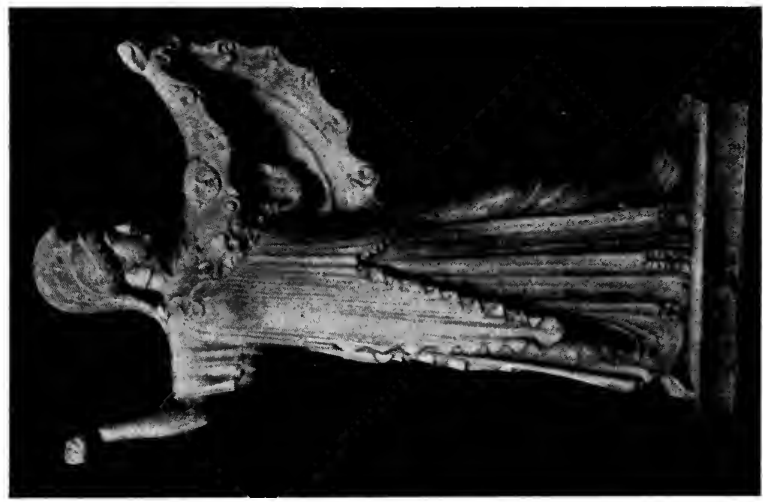

हี 


\section{NAPLES}

vations at Pergamon (see Pergamon collection at Berlin, page 134).

So noble is the attitude and exquisite the figure of this dead female warrior that we are not surprised at the valour attributed to her and her sisters in the mythical days of the Hittites and the Greeks. According to the Greek writers, her name, Amazon, is from two Greek words meaning "without a breast." This popular etymology came from the belief that the right breast of the war-like creatures was removed that it might not interfere with her use of the bow and the javelin. In Greek legend these women warriors lived on the coast of the Black Sea and in the Caucasus Mountains; the West Indian myths place them in South America; and authorities on the Hittites say that the famous legends of the Amazons give the chief evidence in classical antiquity of the influence of that people in Asia Minor. If we follow the legendary history of the Amazon female warriors conquering the people of Asia Minor and building famous cities on the Egean Sea-Smyrna, Ephesus, etc.-we will find that it is really the history of the priestesses of the Asiatic goddess MA, whose cult advanced with the Hittite armies from their ancient capital, Carchemish, on the Euphrates, to the Mediterranean Sea. And when, later, Ephesus came into the hands of the Greeks, the goddess became the Greek Artemis or Diana. 


\section{WHAT SCULPTURE TO SEE}

We know, however, that there was no more favourite theme with the Greek sculptors from the fifth century B. C. than the story of the Amazons and their contests; and King Attalus I, of Pergamon, certainly showed them honour when he sent this beautiful statue to Athens. It is not known when these four statues-the Amazon, Typhæus, a Persian warrior and a Gaul warrior-were brought to Italy, but it could not have been before the capture of Athens by the Crusaders in 1205.

An ancient statue of special interest is that of "Pallas Athena" (Fig. 7), considered one of the finest archaic statues extant. The stiff straight folds of her double mantle accord well with the dignity of her office of fighter or champion of an army or people. Across her left arm is hung the Egis or shield given her by her father Zeus (Jupiter or Jove). This defensive armour was said to have been originally the skin of the goat Amaltha, the foster-mother of Zeus, allegorically the storm-cloud around the thunderbolt, and this armour became the scaly cloak or mantle bordered with serpents and Medusa's head. Athena's helmet is adorned with a crouching gryphon, the emblem of vigilance.

Athens was named for Athena, the goddess of wisdom, and her oldest image, according to tradition, fell from heaven before historic time and was worshipped in her ancient temple on the Acrop- 


\section{NAPLES}

olis. All this honour was none too great for one who sprang fully armed from the head of the great Zeus, and the Athenians proved it when they dedicated that most beautiful of all temples-the Parthenon-to her (see British Museum, page I8I), and enshrined her image in its holy of holies.

But Athena was not always kind in her wisdom. We know that her contest with Neptune brought wealth to Athens (see page I83), but was it a blessing when she changed Arachne to a spider? Foolish Arachne! In her pride over her beautiful tapestries and embroidery she thought a mortal could contest with a goddess, and cried,

"Let Athena (Minerva) try her skill with mine; if beaten I will pay the penalty." This boasting angered Athena, but she gave the headstrong girl a chance to save herself. She went to her, disguised as an old woman, and in a friendly tone, said,

"I have had much experience and I hope you will not despise my counsel. Challenge your fellow mortals as you will, but do not compete with a goddess. I advise you to ask her forgiveness for what you have said and, as she is merciful, perhaps she will pardon you."

"Keep your counsel for your daughters or handmaids," cried the blinded Arachne, "for my part I know what I say and stand to it. I am not afraid of the goddess; let her try her skill if she dare venture." 


\section{WHAT SCULPTURE TO SEE}

"She comes," said Athena, as she dropped her disguise. Arachne was undaunted, though the nymphs and bystanders trembled with terror. The place of the contest was arranged and the weaving began. Athena wrought on her web her victory over Neptune, while Arachne chose subjects for her web to show the failings of the gods and goddesses. So wonderful and lifelike were the scenes Arachne wrought that even Athena admired; yet in her jealous anger she struck the web and rent it in pieces and touched the forehead of the boastful girl to make her feel her guilt and shame. Then Arachne repented and went and hanged herself. When Athena saw her hanging limp and all but lifeless she cried,

"Live, guilty woman-and that you may preserve the memory of this lesson, continue to hang, both you and your descendants, to all future time." And the spider still hangs by the thread of her own spinning.

"The Farnese Bull" (Fig. 8) is a group made by the brothers Apollonius and Thauricus, about I 00 B. C. The mighty struggle of the sons of Zeus and Antiope to hold the ferocious animal while they bind the cruel Queen Dirce to his horns is wonderful in its illustration of the superiority of human strength over brute force. The artist has condensed into the forms of the noble youths the whole story of the injured mother and their intense 


\section{NAPLES}

desire for righteous revenge. We almost forget that the story of Antiope is only a myth and that the young men never lived, so anxious are we that the bull should assist in inflicting punishment. Poor Antiope, so the myth runs, had to flee from the anger of her husband, Lycus, the usurping king of Thebes, and when her twin sons were born she left them on Mount Cithæron to be brought up by the shepherds. She was treated very cruelly by Lycus and was finally made the slave of his wife Dirce, but Antiope fled from the hated bondage and came again to the place where her sons were born. As fate would have it, Queen Dirce soon arrived to celebrate a festival occasion and recognised her former slave. She called for the sons, who had grown to manhood and were her devoted followers, and commanded them to tie their unknown mother to the horns of the bull. But just as they were carrying out Queen Dirce's commands the shepherds told them the story of their birth, and that the woman they were so cruelly treating was their mother. When Amphion and Zethus learned the truth they turned upon the cruel queen and tied her to the horns of the bull, as she had ordered their mother to be tied. Pliny mentions this group as carved from one piece of marble; either he is wrong or he means merely one continuous piece of marble, as several blocks are joined together. The group was found in a 


\section{WHAT SCULPTURE TO SEE}

badly ruined condition in the Baths of Caracalla, Rome, in I 546 ; it had been brought from Rhodes to Rome about A. D. 4. Evidently it was intended for an open place, for it is finished with equal care on all sides.

When the "Farnese Hercules" (Fig. 9), a famous statue brought from Athens to Rome by Caracalla, was found in his baths in 1540 , it was without legs. Cardinal Farnese requested Michael Angelo to restore them, but he refused, saying that he was not worthy to make even a finger for so grand a statue, so the sculptor Della Porta made the restoration. Twenty years later the original legs were found in a well of the Villa Borghese and the ancient statue was then restored to its pristine perfection and the new legs placed in the Villa Museum. The signature on the statue of Hercules shows that it was made by Glycon, of Athens, of the school of Polycletus, about the beginning of the Christian era. The statue is no doubt a copy of an older type, where strength and bodily proportions were the main points of perfection.

The ancient hero is resting on his club after performing the eleventh labour of obtaining the golden apples of the Hesperides that he holds in his right hand. The stories of the wonderful exploits of this Grecian hero are so real that it seems possible that such a youth as Hercules did 

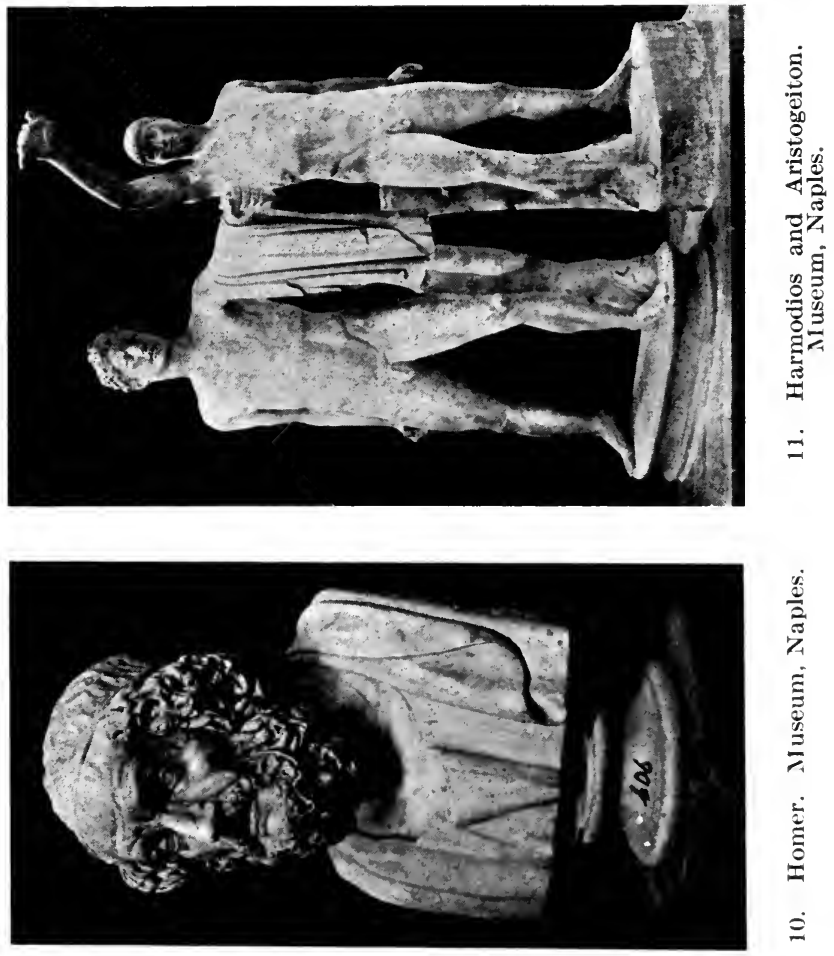

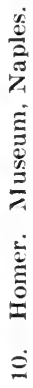

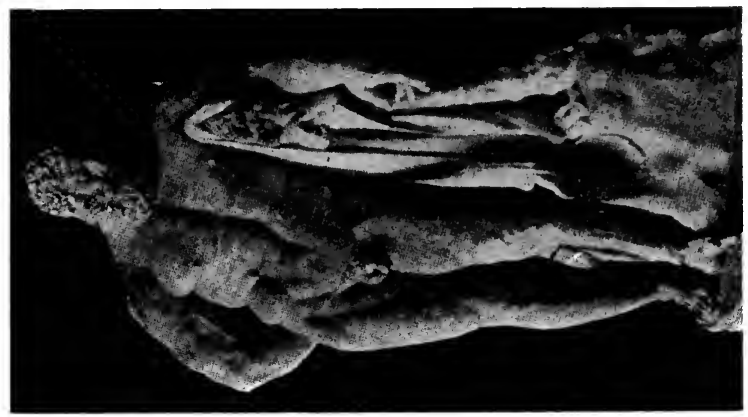

$\overrightarrow{0}$

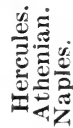

电导

롱

도을

든

$E$

$\sigma^{\circ}$ 


\section{NAPLES}

live. One never tires of hearing about the twelve labours:-

"The Nemean lion first he killed, then Lernë's hydra slew;

The Arcadian stag and monster boar before Eurystheus drew;

Cleansed Augeas' stalls, and made the birds from lake Stymphalis flee;

The Cretan bull, and Thracian mares, first seized and then set free;

Took prize the Amazonian belt, brought Geryön kine from Gādes;

Fetched apples from Hesperidës and Cerberos from Hādes."

Another statue of Greek style and great merit is the "Farnese Gladiator." The agony of pain and defeat is upon him. His open lips and filmy eyes show that the end is near; and his trembling legs warn us to stand aside, for in another instant his strength will fail and his lifeless body will fall before us.

One of the finest ideal portraits of a man whom many critics believe did live, is that of "Homer" (Fig. 10). One wonders how it was possible for an artist to conceive so noble a head of the blind poet and minstrel. The lift of the eyebrows and the wide open lids with eyeballs turned toward heaven and face slightly raised tell plainly that the seeing mind has visions greater than those of mere physical sight. The wrinkled forehead, shrunken 


\section{WHAT SCULPTURE TO SEE}

cheeks and parted lips show that years of eager thought have brought serenity of mind and quietness of body. Enthusiasm still lingers, but the wisdom of age guides it to fruition. One can well understand how such a man could make the story of ancient Troy live for us in the Iliad, and the travels of Uiysses a reality in the Odyssey. The bust was found in the Theatre of Herculaneum, but no hint is given as to the artist who made it.

Among the really genuine portraits of the Roman Emperor Julius Cæsar is the fine colossal bust in the Corridor of the Roman Emperors. This bust is said to be the one selected by Napoleon III for the frontispiece of his "Life of Cæsar."

Also the statue of "Caligula" is probably the most authentic of any portrait of that inhuman monster. This emperor was so savage and vindictive that he was wont to exclaim in his paroxysms of rage, "Would that the Roman people had only one head." The Emperor Caligula's real name was Caius Cæsar-Caligula was a nickname from the foot-gear worn by the common soldiers that young Caius used to wear when he followed the army as a boy.

We might say of the statues of "Harmodios and Aristogeiton" (Fig. I I), that they not only stand as a connecting link between the early Attic school, which combined all that was best of the Doric and Ionic schools and the later school of Pheidias and 


\section{NAPLES}

Praxiteles, but that the stories of their vicissitudes explain, in a measure, the reason why there are so few original Greek works in the museums of Europe, and those mostly in fragments.

During the Persian invasion in 480 B.C. Xerxes, with his great army, swept over Greece, destroying everything before him. No city was more completely demolished than Athens; walls, temples and works of art were thrown down, regardless of artistic value or beauty of workmanship. Fortunately, however, when Xerxes saw the original statues of "Harmodios and Aristogeiton" standing in the market-place of Athens he was so delighted with them that he carried them away to the Far East. There they remained until Alexander's time, more than a century later, when that great ruler returned them to Greece.

In the meantime the Athenians had returned to their all but ruined city and, with the vigour of artistic youth still upon them, found it easier to build new than to repair. The materials of the overthrown temples and broken statues were simply débris to them, so the stones, marbles, terracottas and bronzes, and the broken statues, friezes, metopes and vases were thrown in together to make a foundation for the new Acropolis, and new temples and new statues took the place of the old. It is this foundation that is yielding untold treasures since 1885 , when was begun the great work 


\section{WHAT SCULPTURE TO SEE}

of uncovering the hill of the Acropolis down to the very living crystalline limestone rock.

It is not strange that among the new statues, made by the returned Athenians, were copies of the "martyrs for liberty, Harmodios and Aristogeiton." The original bronze group was made by the artist Antenor, about 5 Io B. C., and the copyAntenor being dead-by his pupils (probably), Critius and Nesiotes, shortly after 480 B. C. It is not likely that the later group was an exact copy, though essentially the same, but was no doubt in bronze. During the days of Pausanias, the second century A. D., the two groups, the one carried away by Xerxes and the new one, seem to have stood side by side in the market-place.

Harmodios and Aristogeiton stand in history as the liberators of Athens from the rule of the tyrants Hipparchus and Hippias, the sons of Pisistratus, who usurped supreme power in Athens in $560 \mathrm{~B}$. C. Hipparchus, the tyrant, was jealous of the love of the beautiful youth Harmodios for his older friend Aristogeiton, and to humiliate him (Harmodios) he refused to let his sister bear the sacred basket in the Athenian festival. This insult infuriated the two friends and, determined to have vengeance, they plotted to slay the tyrants, Hipparchus and Hippias, on the day of the festival. Through an immature attack only the tyrant Hipparchus was killed, but Harmodios also was slain and Aristogei- 


\section{NAPLES}

ton taken prisoner. The latter was put to the torture but took revenge by renouncing the friends of the tyrant Hippias as belonging to the conspiracy. This did not save the life of Aristogeiton, but it was the means of the overthrow of Hippias and the final freedom of the city from the hated rule of the Pisistratidæ.

The Naples marble statues of Harmodios and Aristogeiton are copies of one or other of the bronze groups seen by Pausanias. Lucian, a keen, critical writer of the second century A. D., says of the sculptors Critius and Nesiotes that their style is "concise and sinewy and hard, and exact and strained in their lines," and such a criticism would apply to these copies in marble. Yet look how well the impetuous strength and youthful vigour of Harmodios, with his expression of honest boyish anger in behalf of his insulted sister, is offset by the calmer though none-the-less righteous wrath of his older friend. Harmodios has his right arm upraised ready to strike, while Aristogeiton wards off an attack on his young friend with his extended left arm and holds his right ready for action. The original bearded head of Aristogeiton was lost and the present more youthful one was added. Pliny says the artists Critius and Nesiotes were rivals of Pheidias, but this can hardly be true, as they were much older men. 


\section{CHAPTER III \\ ROME-VATICAN}

WITHOUT question the most celebrated statue in Rome is the "Apollo Belvedere" (Fig. I2). This statue was found at the end of the fifteenth century during excavations at Antium, the seashore resort of the Roman emperors, especially Caligula and Nero. The statue was fairly intact, except for the fingers of the right hand and the hand and wrist of the left arm, but more controversy has raged over the restoration of those parts than over that of any other statue, unless it be the Venus de Milo (Fig. 104).

Until about sixty years ago, critics were fairly agreed that the god had just let fly an arrow from his right hand and that the left held the bow-the restorer, Montorsoli, had that idea and used the stump of the bow. But after attention was drawn to Count Stroganoff's small (about twenty inches high) bronze statue of Apollo, in St. Petersburg, which holds folds in its left hand that might be the ægis with the Gorgon head, it is thought that the Apollo Belvedere was represented originally as shaking that dread banner before his enemies. The statues are much alike in 


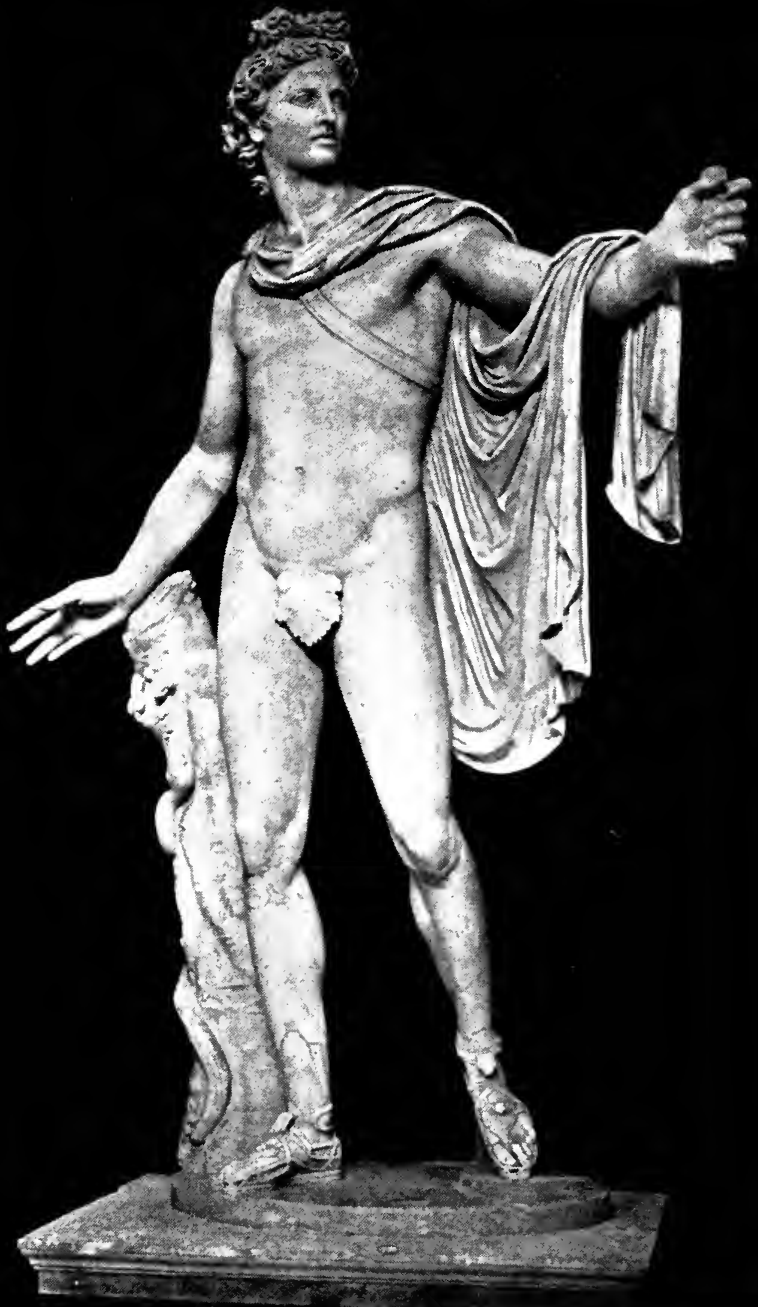

12. Apollo Belvedere. Vatican, Rome. 


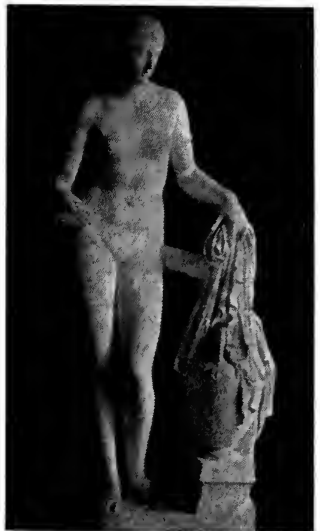

13. Aphrodite (Venus) of Cnidus. (From an undraped cast.)

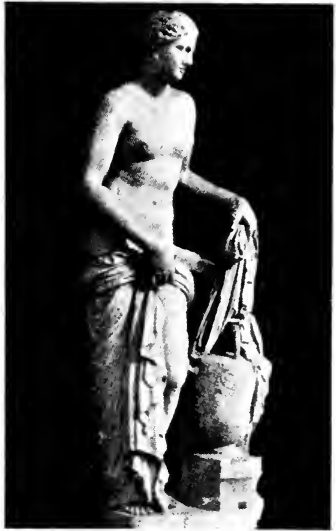

14. Aphrodite (Venus) of Cnidus (draped). After Praxiteles. Vatican, Rome.

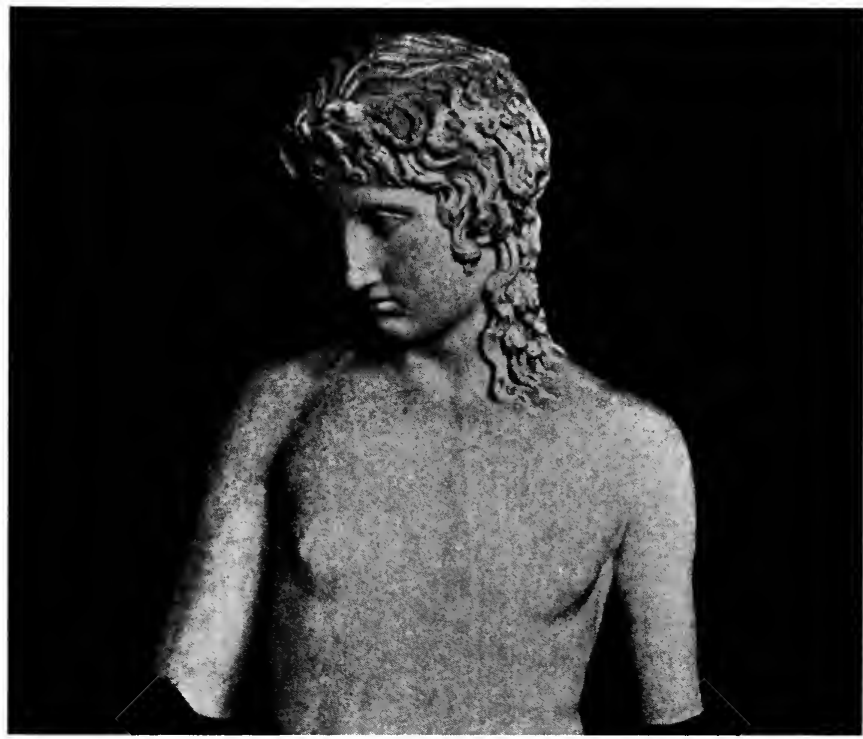

15. Eros from Centocelle. Vatican, Rome. 


\section{ROME}

pose, only the right hand of the bronze one is drawn nearer the body. Fortunately both arms and hands in the bronze were perfect when found and the drapery, simply thrown over the shoulder and falling down the back, is now thought to be a remnant of the original which may have been like that of the Apollo Belvedere.

The scornful curl of the lips and the proud tilt of the head seen in the Apollo Belvedere seem in better keeping with the use of the ægis to show displeasure than with the vindictive use of the arrows to kill his enemies. His pose is quite like one who has just descended from high heavens in defense of his beloved shrine. When Delphi was attacked, 279 B. C., by the fierce Galatians from the north, the belief was that the beautiful Apollo, clothed in glorious light, descended through the temple roof and, shaking the ægis before the advancing hordes, brought a terrific storm of thunder and lightning, hail and rain which caused confusion and panic and complete overthrow of the enemy.

Apollo, the son of Zeus and Latona and twin brother of Artemis (Diana), as,

"The god of life, and poesy, and light, The sun, in human limbs arrayed, and brow All radiant from his triumphs in the fight,"

never looked his part more truly than in the Vatican 


\section{WHAT SCULPTURE TO SEE}

statue. That the original Apollo Belvedere was a Greek work is unquestioned, and its resemblance to the head of Helios, the god of light, on coins from Rhodes; shows that this conception of the god was of still earlier date.

The undraped statue of "Aphrodite of Cnidus" (Fig. I3), is taken from a cast of the draped goddess (Fig. 14), in the Vatican. The authorities forbid photographs of Aphrodite without her tin drapery-added in the eighteenth century-but did allow a cast to be made of the nude statue. That Praxiteles' celebrated "Aphrodite of Cnidus" was undraped is proved by the nude goddess on Cnidian coins and by extracts from Lucian's writings. The latter says:- "The goddess stands elevated in the middle of the temple, a most perfect form of art in Parian marble, her lips slightly parted as in a gentle smile. Her whole beauty appears, no drapery enveloping her form; but as though involuntarily, she covers herself with her hand. So great is the power of the sculptor's art in this form, that the stone, hard and obdurate, seems as though suited by nature to render all the soft and graceful members." We also learn that this statue, so cherished by the Cnidians before the Christian era, at the end of the fourth century A. D. was in Constantinople in the palace of Lasus, where it stood for nearly a century, and was then destroyed by fire.

$$
\text { [44] }
$$




\section{ROME}

The original statue of "Aphrodite of Cnidus" probably represented the renowned beauty Phryne, the favourite of Praxiteles. Phryne was a peasant girl from Bœotia, very poor, but as she grew to womanhood her loveliness attracted all Athens and brought her lovers, renown and great wealth-and among her lovers was Praxiteles. "The Cnidian Aphrodite" was made about 350 B. C. Pliny styles this bronze statue not only the most wonderful of Praxiteles' but the most beautiful in the world.

But a statue, a copy of another of Praxiteles' work, that is more satisfactory because saved from the hands of the restorer, if not from the prudery of authorities, is "Eros, from Cintocelle" (Fig. I5), often called "The Genius of the Vatican." In ancient times the Greek original of this statue -which is probably a copy of many copies-was almost as celebrated as the "Aphrodite of Cnidus." It is known from ancient writers that Praxiteles made a statue of "Eros" (Cupid) that he prized very highly - so highly that Phryne determined, by strategy, to know which equalled it. Praxiteles had promised Phryne, so the story runs, to give her his most beautiful work, but delayed to fulfil his promise. She became impatient and one day sent her slave to tell him that his studio was on fire. This false alarm had the desired effect, for Praxiteles rushed out, exclaiming that all his labour was

$$
\text { [ } 45 \text { ] }
$$




\section{WHAT SCULPTURE TO SEE}

lost if his "Satyr" and "Eros" were lost. The "Satyr" was the original of the "Marble Faun" (Fig. 32) of the Capitoline Museum.

For a long time critics looked upon the Vatican "Eros" as a direct copy of the original, but more probably it is a Roman copy of the second century of our era and bears very little resemblance to Praxiteles' "Eros," though it is a beautiful work.

In 1777 , on the Palatine Hill, Rome, was found the "Apollo Sauroktonus" (Fig. I6), of the Vatican. According to Pliny, Praxiteles carved a bronze statue of "a young Apollo with an arrow on the alert for a lizard which is creeping toward him, which men call the 'Sauroktonus' (lizardkiller)." This statue has usually passed as a copy of the one mentioned by Pliny, but a more careful study of the expression and pose reveal the god as resting and musing, rather than on the alert for the nimble animal creeping toward him. There is the easy grace of Praxiteles with the flowing lines of a leaning figure and also the withdrawn look of the inward seeing eyes like those of the "Hermes" of Olympia, the one genuine work remaining of the great master. Has not the lizard dared to climb the tree-trunk because the dreaming god gives no sign of life in his abstraction?

Praxiteles was an Athenian, and was at the height of his career, according to Pliny, from 364 to $36 \mathrm{I} \mathrm{B}$. C. when probably less than thirty years 

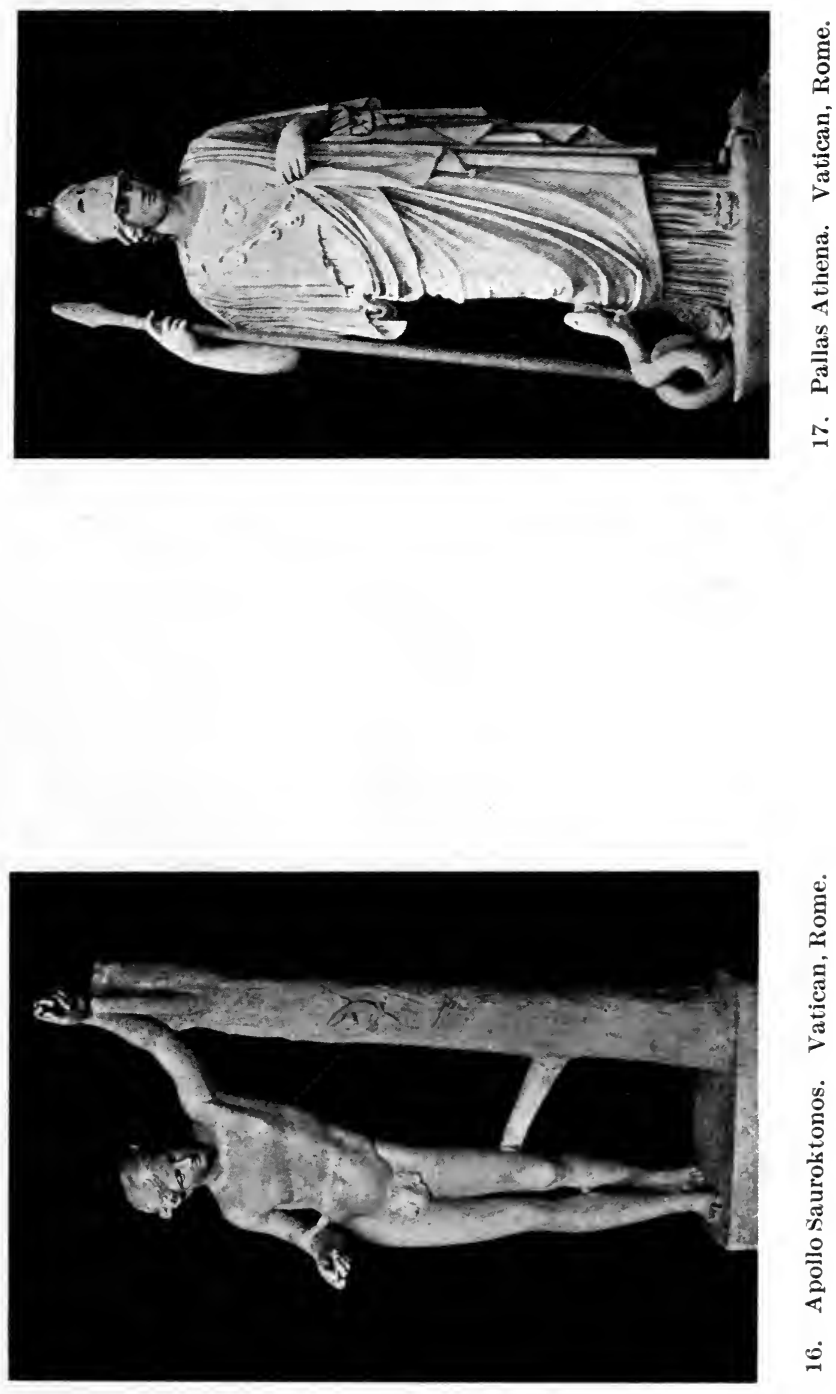

 


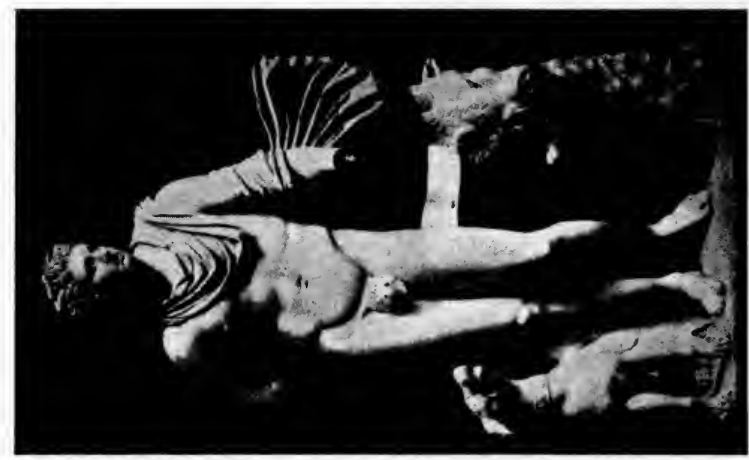



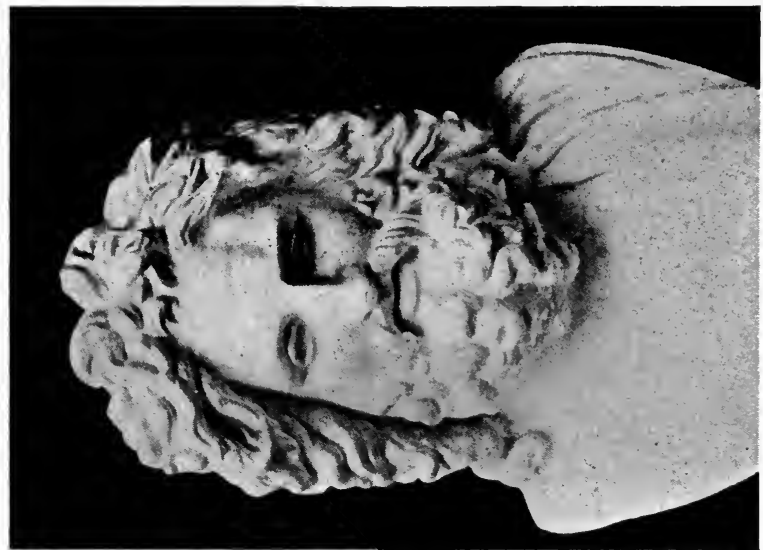

苞

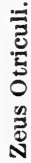

$\stackrel{\infty}{-1}$ 


\section{ROME}

old. Ancient writers say much in admiration of Praxiteles' work and also make many allusions to the beautiful Phryne, and intimate that she was his model for the "Aphrodite of Cnidus" about 350 B. C. These meagre facts were greatly enhanced by the finding of the precious original "Hermes," on almost the same spot where Pausanias had described it.

The "Pallas Athena" (Minerva) of the Vatican (Fig. I7), is often confused with the "Athena Medici" (Fig. I34), now in the Ecole des Beaux Arts, Paris, but a comparison of the two will show how very inferior it is to that copy of an original by Pheidias. The sculptor of this one had in mind, no doubt, the Athenian statues by the Greek master, but he was too much influenced by the Roman love of elaborate drapery and graceful posing which had taken the place of the severe simplicity in the drapery and pose of the Greeks. There is, however, a dignity of bearing and calm repose, even in this statue of the decadence, that marked the Pheidian type.

In the "Bust of Zeus" (Fig. 18) from Otricoli, is another work long thought to be a direct copy of the Pheidian "Zeus" of Olympia, but now discredited by critics and relegated to the modern modification of the Pheidian type. The unquiet eyes and the frown of the forehead destroy the grand simplicity that marks the Parthenon mar- 


\section{WHAT SCULPTURE TO SEE}

bles and that must have belonged to the Olympian Zeus. Ancient writers have again and again referred to the latter statue. One writer says:- "To reveal his likeness to thee, Zeus came down to earth; or thou thyself, Pheidias, didst go to see the god." Again, "No one who has seen Pheidias' Zeus can imagine any other resemblance of the god." Lucian says of it, "Those who enter the temple no longer think that they see ivory from Indus, or beaten gold from Thrace, but the son of Cronus and Rhea, transferred to earth by Pheidias." Alas, that only a shadow of that great Olympian masterpiece remains in the Zeus of the Vatican!

Zeus, the father of the gods and men, himself had a beginning as the son of Cronus (Saturn) and Rhea the daughter of heaven and earth. To keep Cronus from swallowing the infant Zeus, as he had his other children, Rhea hid him and gave to Cronus a stone wrapped as a child, which he swallowed, thinking it the child. When Zeus was grown, he married Metis (Prudence) who gave Cronus a concoction that caused him to disgorge his children and the first to come up was the stone infant Zeus; this stone Zeus set up at Delphi. When Metis was to give birth to a child, Zeus, jealous for fear it might be a boy and dethrone him, took the child from the body of Metis and placed it in his own head and that explains how 


\section{ROME}

Athena came forth from the head of Zeus (see page 18 ).

The statue of "Meleager" (Fig. 19) was found about the beginning of the sixteenth century. It is possibly a copy of a work by Scopas or of his school. Scopas, a sculptor a little older than Praxiteles, was a native of the island of Paros, but he spent much of his time in the Peloponnesus and Athens. One of his most extended works was the rebuilding of the temple of Athena at Tegea, in the Peloponnesus, which in 394 B. C. was destroyed by fire. Pausanias enthusiastically describes this temple and its decorations and says that the sculptured scene in one of the pediments represented the mythic hunt of the Calydonian boar and mentions among many other statues that of Meleager. The story of Meleager and the boar hunt was very characteristic of the works of Scopas, for he, unlike Praxiteles, loved vivid scenes with intense action. A good example showing his intense action is the "Daughter of Niobe," in the Vatican, a headless statue found at Tivoli. It is a Greek copy of one of the figures from that famous group of "Niobe and her Children" (see Niobe group, Florence, page 85 ).

Meleager was the son of the king and queen of Calydon. When he was born, the three Destinies prophesied to his mother that he would live only so long as the brand would burn that lay on the 


\section{WHAT SCULPTURE TO SEE}

hearth. The mother snatched the brand, instantly quenched the fire and laid it away. But when Meleager grew to manhood his father, the king, neglected one day to pay due honour to Artemis, and in revenge the offended goddess sent an enormous boar to destroy the fields of Calydon. Meleager called upon the heroes of Greece to come and help destroy the monster. Not only did the young men come, but Atalanta, the swift of foot, the daughter of the king of Arcadia, came too. Meleager saw her and loved her. At last, after a fierce struggle, Meleager killed the boar and gave to Atalanta the head and rough skin, trophies of his success. But envy filled the hearts of the other contestants and the brothers of Meleager's mother, bitterest of them all, wrested the prize from the hands of the fair Atalanta. Meleager in his anger rushed upon and slew his uncles, and then his mother, in her blind fury at the death of her brothers, set fire to the brand and ended the life of her own son.

The "Torso of Hercules" (Fig. 20) is inscribed with the name of Apollonius on the rough base, an artist of Athens who lived in the first century B. C. It is said that Michael Angelo used to come and pass his fingers over the surface of this broken statue in his sightless old age-and surely the marble does seem to yield to the pressure of the fingers, so like flesh is the texture.

[ 50 ] 


\section{ROME}

The "Torso" was found near the theatre of Pompey in the sixteenth century. The lion skin marks the statue as representing Hercules, but a neverending controversy wages over what it represents him doing. 


\section{CHAPTER IV \\ ROME-VATICAN (Continued)}

$7 \mathrm{O}$ appreciate the real artistic merit of the 1 "Discus Thrower" (Fig. 2 I), a marble copy of a bronze statue by Myron, in the Vatican, one needs to compare it with the more accurate.copy found on the Esquiline Hill in 1761 and now in the Palazzo Lancelotti (Fig. 22). As the latter is in the private apartment of the prince a special permission is necessary to see it. Lucian says of the original bronze as he saw it in Athens, "You speak of the discus thrower, who bends, preparatory to throw, with the face toward the hand holding the disk, and with one leg bent as though to rise again after the throw." The Vatican copy has a modern head, and wrongly placed-another error of the restorer.

Myron (about 500 to 440 B. C.), a fellow student with Pheidias, was noted for his representation of action pure and simple. In the "Discus Thrower" one not only feels the working up of the muscles to the point of greatest action but also the letting down that gives relief. The dragging left foot is just as eloquent of regained rest as the clinging force of the right foot is of greatest

$$
\text { [ } 52 \text { ] }
$$



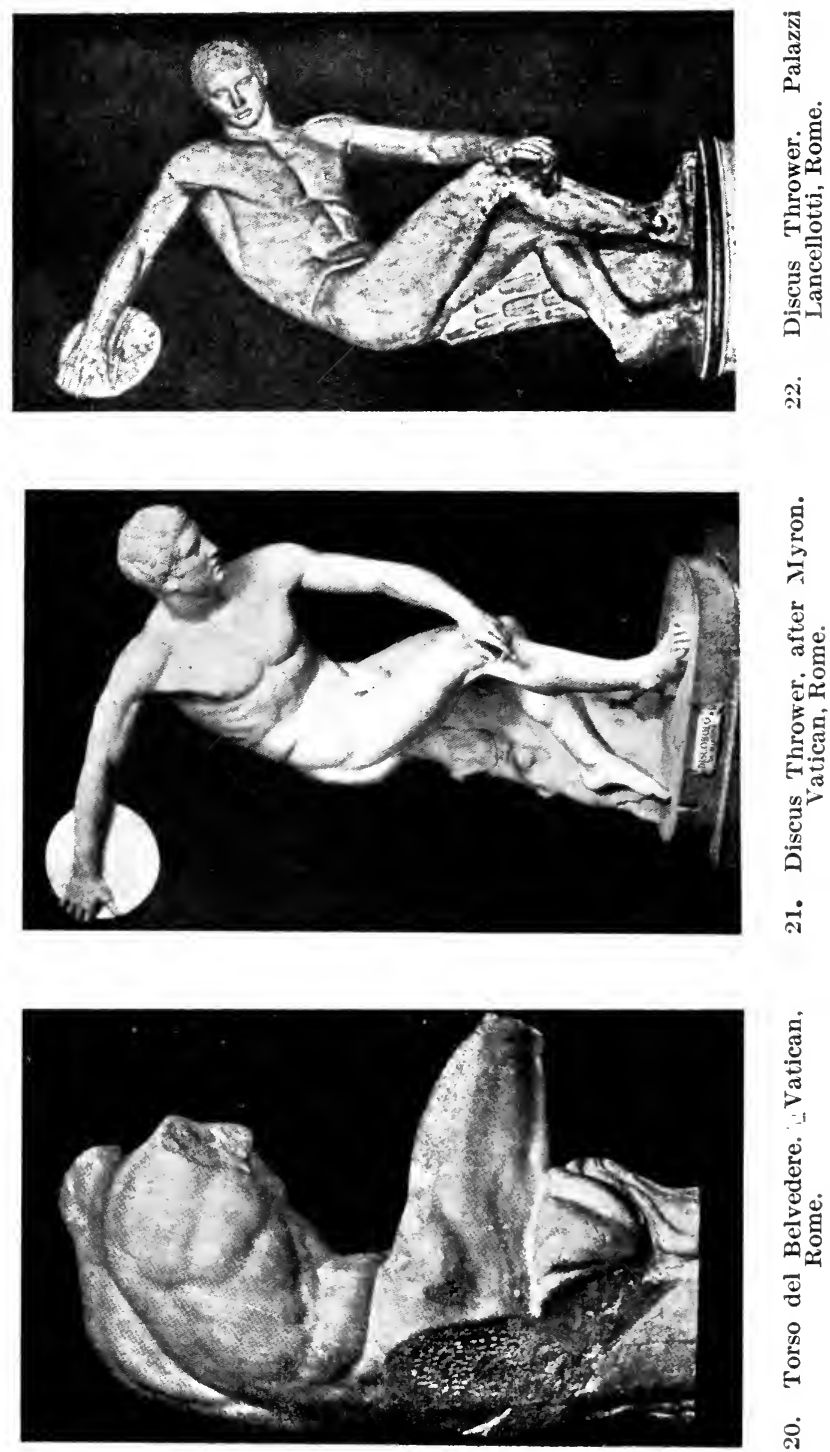


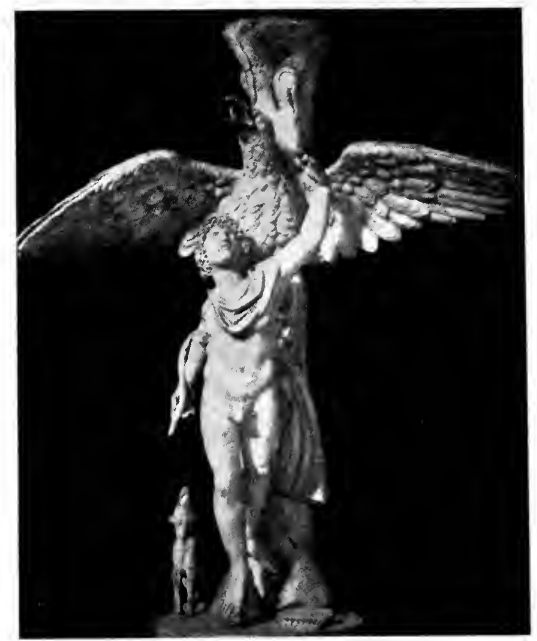

23. Ganymede and the Eagle. Vatican, Rome.

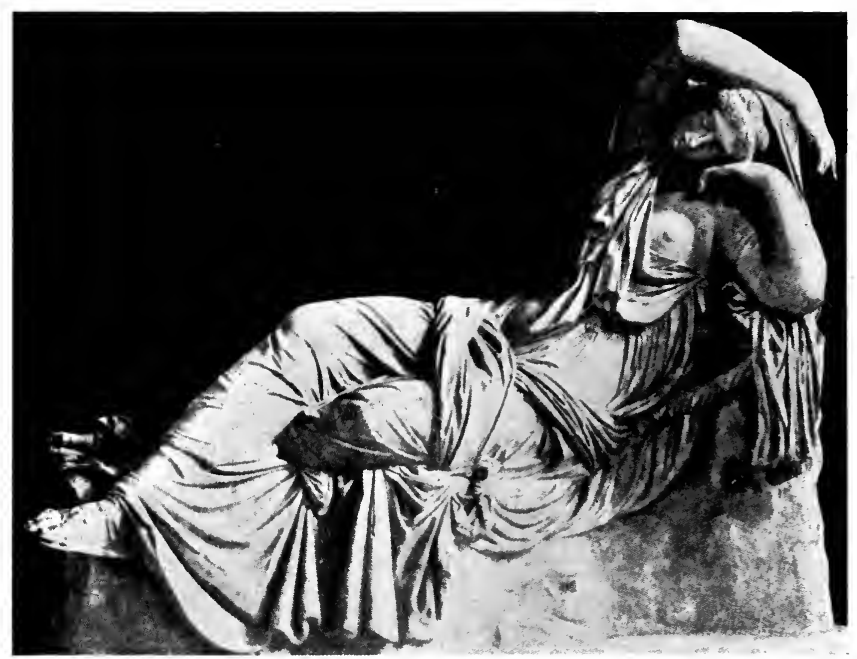

24. Ariadne. Vatican, Rome. 


\section{ROME}

strain. Only an instant and the whirling disk will sing through the air and the bowed athlete will spring to rest with head thrown back and chest expanded.

Among the most celebrated of Myron's animal pieces was his far-famed "Cow." In Cicero's time it stood on the Pnyx Hill, Athens, and still later in the Temple of Peace, Rome. We learn from a score or more of ancient epigrams about her life-likeness, that lions tried to tear her in pieces; calves sought her bronze udders; gadflies settled on her metal skin; shepherds tried to drive her, to halter her and hitch her to the plough; in fact that even Myron himself could scarcely distinguish her from the rest of his herd. But all trace of Myron's "cow" is lost.

Pliny says of the original of "Ganymede and the Eagle" (Fig. 23), by Leochares of the fourth century B.C., that even the eagle seems to be conscious that his burden is precious and that an honour has been given him, in the gentle way he grasps, through the drapery, the tender body of the beautiful boy. The eagle has that upward strain in the plastic marble that it must have had in the bronze original. The bit of realism in the little dog, as in his agony over the loss of his master he stretches his neck upward to its utmost capacity, is delicious in its truth to nature.

The story of Ganymede is rather a contradictory

$$
\text { [53] }
$$




\section{WHAT SCULPTURE TO SEE}

one, but he is usually considered as a Trojan lad whom Zeus decided was to take the place of cupbearer, left vacant by the marriage of his and Juno's daughter Hebe to Hercules. Zeus either went for the boy himself, as an eagle, or he sent an eagle to Mount Ida and seized him from among his playmates. Homer, however, makes Ganymede the son of Tros and Callirrhoë who, because of his great beauty, was carried off to live with the gods and to be the cup-bearer of Zeus.

Another copy of a bronze statue made by a fourth century B. C. artist, Lysippus, is that of "Apoxyomenos" (the scraper). This marble copy, found at Trastevere in 1849 , represents an athlete cleaning the oil and dirt from his right arm with an iron scraper. It is said that Agrippa placed Lysippus' bronze "Apoxyomenos" before his bath in Rome. Tiberius, however, admired it so much that he had it placed in his own private apartments, but the clamour of the people over the loss of their favourite work of art compelled him to return the statue to its original place in front of the bath.

The "Sleeping Ariadne," of the Vatican (Fig. 24 ), is one of the most beautiful reclining figures in all art. The statue was found in the reign of Julius II and at one time was thought to represent Cleopatra. But upon comparing this colossal figure with its companion-piece at Madrid, and also with reliefs on sarcophagi, where the sleeping Ariadne 


\section{ROME}

is pictured with Theseus on one side hurrying away to his ships and on the other Dionysos seeking his bride, it seems without doubt a representation of the forsaken wife.

Theseus, so Greek myth says, started out to free the Athenians from paying the awful tribute - seven maidens and seven youths-demanded by Minos, king of Crete, as a yearly sacrifice to the monster Minotaurus. When he arrived at Crete with his tribute of youths and maidens, Ariadne, the daughter of the king of Crete, came with her father to see the yearly offering. She no sooner saw Theseus than she loved him-and he loved her in return. As a token of her love, she furnished her lover with a sword to kill the hated monster and a thread to lead him out of the labyrinth. As soon as the deed was done and Theseus had escaped from the labyrinth, he took Ariadne and started for Athens. On the way home, he stopped at the island of Naxos, and while there Ariadne was so unfortunate as to fall asleep, and while she slept Theseus sailed away. When Dionysos found the deserted bride he married her and then placed her marriage crown among the stars, where it can be seen to-day.

The famous "Laocoön" group (Fig. 25) was found on the site of the palace of Titus, Rome, in I 506. It is interesting to read Francesco Gallo's account of going to see the group. He says, 


\section{WHAT SCULPTURE TO SEE}

"Michael Angelo, who was almost always at home with us; was just there. My father begged him to go, too; and so we three set out, I behind my father. When we dismounted where the statue lay, my father said at once, 'That is the Laocoön which Pliny speaks of.' They now enlarged the opening, so that it could be drawn out. After we had examined it, we went home and breakfasted."

The group was intact, except that the right arms of Laocoön and his youngest son were missing. If only Michael Angelo had restored them he doubtless would have preserved the original pyramidal form of the group by throwing the arms of the father back of his head and bending that of the son's toward the father. As it is stupidity marks the restoration.

In this group we have one of the few remaining examples of the Rhodian school. Exaggerated as the action is, the calm dignity in the agonized face of the tortured priest gives a sense of elemental strength. It is strength so deep that no sound could come from the parted lips. The agony of his suffering has left its physical mark on face and body, but no torture could conquer the immortal soul suffering in silence. Michael Angelo declared this group "a marvel of art."

Although the Laocoön group stands in the Vatican, yet with little imagination we are on the distant coast of Asia Minor outside the walls of

$$
\text { [56] }
$$




\section{ROME}

ancient Troy. The wooden horse, left by the wily Greeks, has just been discovered by the Trojans and Laocoön, the priest, is trying to persuade them that disaster will come if the horse is taken into the city. He exclaims, "For my part, I fear the Greeks even when they offer gifts!" and strikes the wooden steed to prove to them their danger. A groan seems to come from within the horse but, before his warning words and the queer sound can fully convince the Trojans, they must listen to a Greek spy. The fellow has come, all out of breath and with seeming terror, exclaims that he has been deserted by the Greeks and that the huge horse is an offering to Minerva-and that it was made large to prevent the Trojans from taking it into their city! And just here, as though to give weight to the words of the spy, Neptune, an enemy to the Trojans, sends two serpents from the sea to destroy Laocoön and his sons at the very altar where they are offering the sacrificial steer. See the huge monsters as

And to Laocoön and his children make;

"their way they take,

Then their sharpened fangs their limbs and bodies grind.

The wretched father, running to their aid

With pious haste, but vain, they next invade;

Twice round his waist their winding volumes rolled; And twice about his gasping throat they fold."

The great master in the Greek genre in sculpt[57] 


\section{WHAT SCULPTURE TO SEE}

ure was Böethus from Asia Minor. The "Boy with a Goose" (Fig. 26), in the Vatican, is one of many marble copies of the bronze original that Pliny highly praises. The goose was the common plaything of the child in the Greek home two thousand years ago-and to-day too for that matter. It was an easy matter for Böethus to find models for his famous group in the back courts of any Greek home. That he saw and studied the real child as he played with his ungainly companion, the struggles of the sturdy little fellow and the gasping efforts of the choked goose bear witness.

The colossal figure of "The Nile" (Fig. 27), with its sixteen little children climbing over it, probably is a copy of an original that goes back to the Alexandrian period, the third century B. C. The little figures represent sixteen different stages of the rise of the waters of the Nile. Those at the feet of Father Nile play in the ooze and slime with the crocodiles picking up food the best they may, for the scant overflow of the waters has brought a very light harvest. But as the waters creep up the huge figure, the children grow merrier and fill their hands with fruits and vegetables until, when the waters have reached sixteen cubits in height, one little fellow stands in the cornucopia surrounded with the abundance that the most fruitful years bring. 


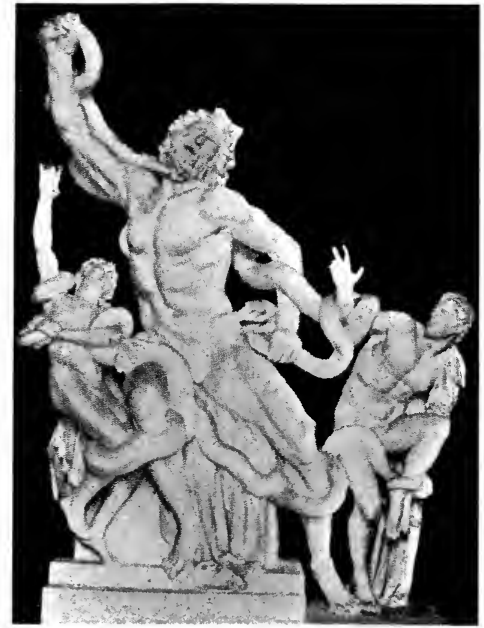

25. Laocoön. Vatican, Rome.

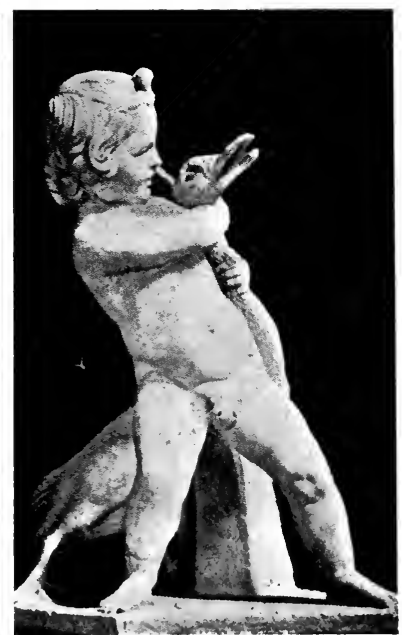

26. Boy with Goose, after Böethos. Vatican, Rome.

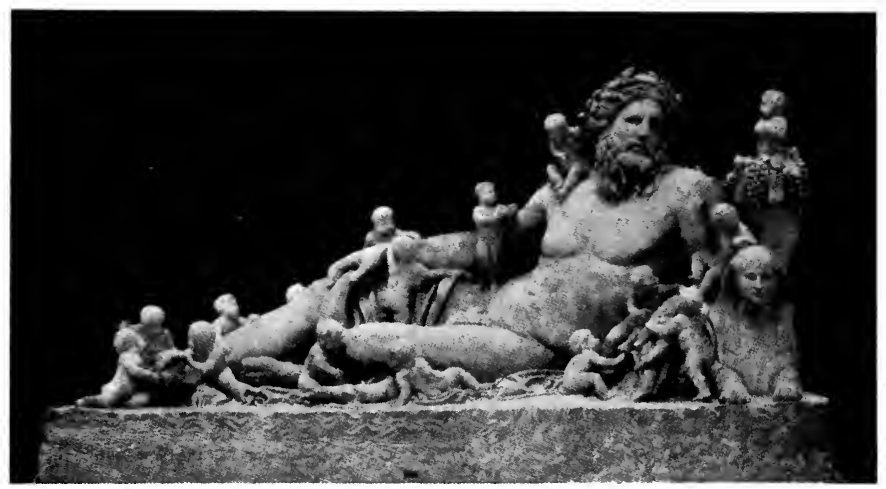

27. Nile. Vatican, Rome. 


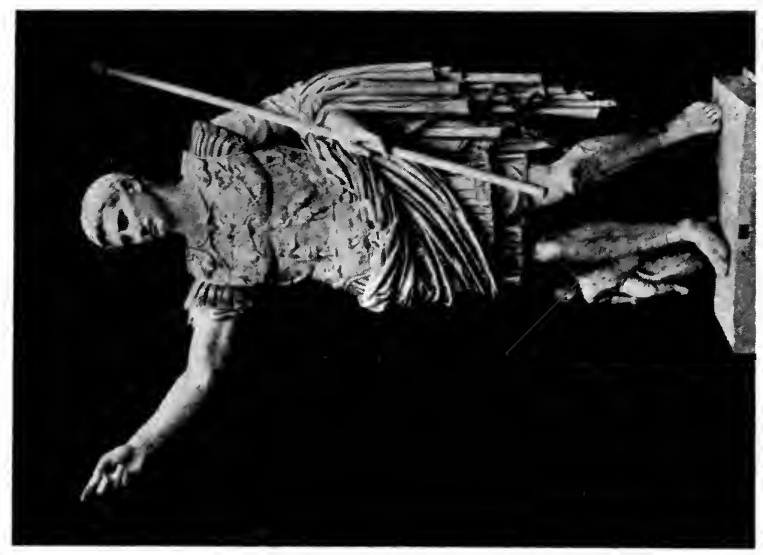

हี

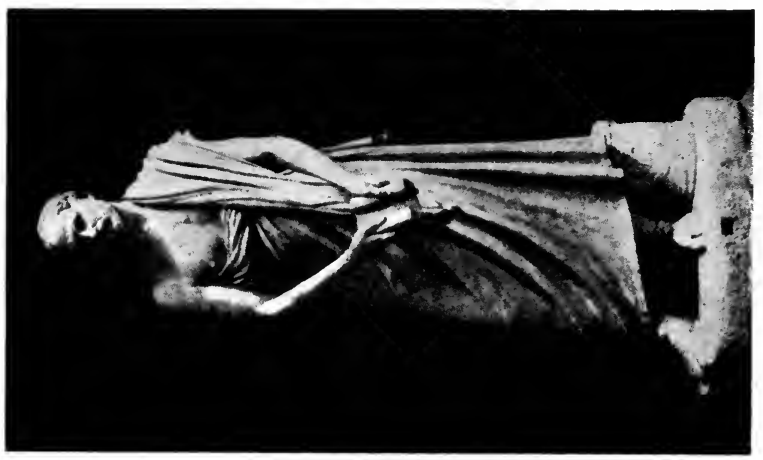

हี 


\section{ROME}

There are six replicas of the group of "Father Nile" in the various galleries of Europe, but the one in the Vatican is considered the best.

A portrait statue of rare excellence, though only a copy, is that of "Demosthenes" (Fig. 28). The original of this statue was by Polyeuctos, a sculptor who flourished in Athens the third century B. C. In his bronze portrait of Demosthenes, set up in Athens in 280 B. C., he represented the orator standing with folded hands, a common ancient attitude, expressive of anxiety and often of affliction. The epigram beneath the statue said, "Had, O Demosthenes, thy piercing and strenuous will been supported by proportionate strength, they might have rescued thy fatherland from Philip."

This statue of Demosthenes, in the Vatican, carries a roll instead of having folded hands, a change, critics believe, due to a time when Demosthenes, having conquered his affliction, had come to be admired as an author and orator. How plainly the set of the mouth tells of the natural hesitancy of speech that would have been the undoing of a smaller man, but with Demosthenes it was only an obstacle to be overcome. The stories of his untiring efforts with pebbles in his mouth and reciting in the roughest and steepest places, of his shouting on the seashore until even the roaring ocean could hear his voice and of his months of retirement, gaining dignity of manner before his 


\section{WHAT SCULPTURE TO SEE}

faithful mirror, have spurred many a discouraged beginner.

The portrait statue of "Augustus Cæsar" (Fig. 29), found in 1863 , in the villa of Livia, near Prima Porta, Rome, is one of the most beautiful works of Roman times. The statue was nearly perfect when found; only a finger, part of an ear and the sceptre were lost. On close examination it seems, however, that the left leg and the extended right arm had undergone repairs in ancient times, an evidence of its value in the past. The statue was originally painted, for there are still faint traces of colour-purple, red, yellow and blue-on the hair, the reliefs on the close-fitting armour, in the folds of the toga and in other details of the figure.

It is possible that the statue was made about I7 B. C., shortly after the emperor's triumphs in the North. The reliefs on his armour, which set forth his principal conquests in fairly correct chronological order, point to the above date and also the emperor's attitude as of one addressing his people. His easy pose and simple gesture are the marks of a ruler who is sure of his absolute power. It was said of Augustus Cæsar in his adorning of Rome, "He found it brick and left it marble."

There are two mutilated Niobe pieces in the Vatican, probably replicas like the Niobe group in Florence (see page 85 ), and like those found near 


\section{ROME}

the Lateran, Rome. One, badly marred and broken, represents a son and daughter, the boy protecting his sister regardless of his own safety. Canova recognised the figures as belonging to the Niobe group. The attitude of the son is the same as the one in Florence (see Fig. 54). The other statue, headless, represents a daughter of the famous group. It was found at Tivoli and is a splendid work, possibly a copy in marble of Scopas or Praxiteles.

Possibly no statue in Rome has had a more varied history than that of Marcus Aurelius (Fig. 30). Standing in the Piazza del Campidoglio, it commands attention from all who enter or leave the .Capitoline Museum-and rightly, for it is one of the most perfect ancient equestrian statues in existence.

The statue was erected to the Roman emperor, Marcus Aurelius Antoninus, who died March I7, I 80. Though not a Christian this emperor was a just ruler, upright in character and magnanimous to his enemies. In fact, one can scarcely believe in reading the history of his life and his own writings, "Meditations," that he was the emperor who so cruelly persecuted the Christians in Gaul.

Originally the statue was gilded and stood in front of the Arch of Severus, the latter erected A. D. 203, over the Sacra Via of the Forum. Some time during the Middle Ages it stood near

$$
\text { [6I] }
$$




\section{WHAT SCULPTURE TO SEE}

the Lateran. Pope John XIII, 965, used the statue as a gallows from which he hung a refractory prefect by his hair. In 1347 , during the rejoicing after Rienzi's elevation to the tribuneship, the nostrils of the horse were made to flow, one with water and the other with wine. The intimate connection of the statue with the Lateran fostered the popular belief that it represented Constantine -the first Christian emperor (3 I I) -and this fortunate error accounts for its preservation. When Michael Angelo designed the Piazza of the Capitol he wished to remove this statue to its present site. The canons of the Lateran objected but were won over by the promise of an annual acknowledgment of their ownership-and even to-day a floral offering is presented once a year by senators to the chapter of the Lateran. Michael Angelo personally supervised the removal of the statue and designed the wonderful pedestal that enables the sightseer to examine every part of the horse and its rider. 


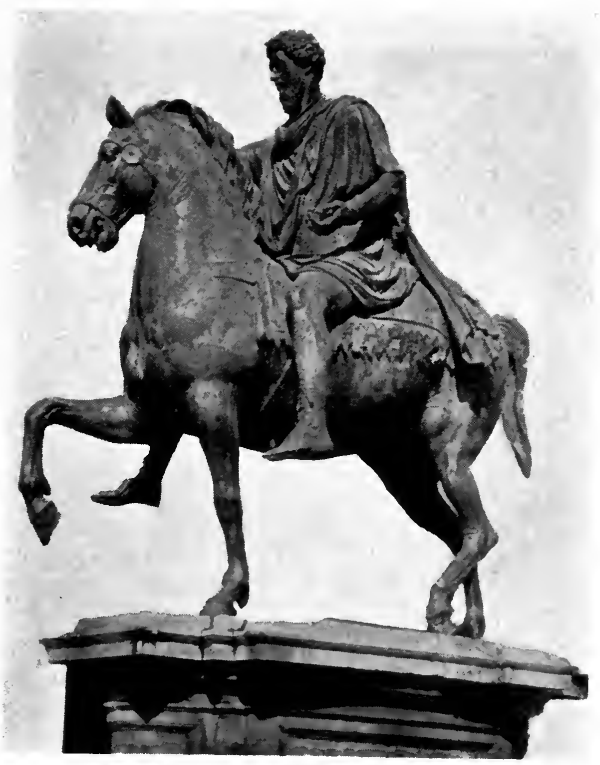

30. Equestrian Statue of Marcus Aurelius. Piazzi del Campidoglio, Rome.

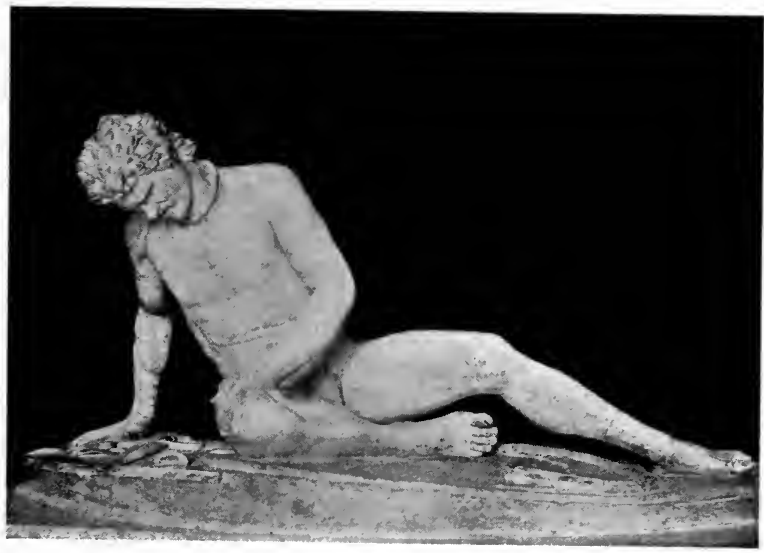

31. Dying Gaul. Capitoline, Rome. 

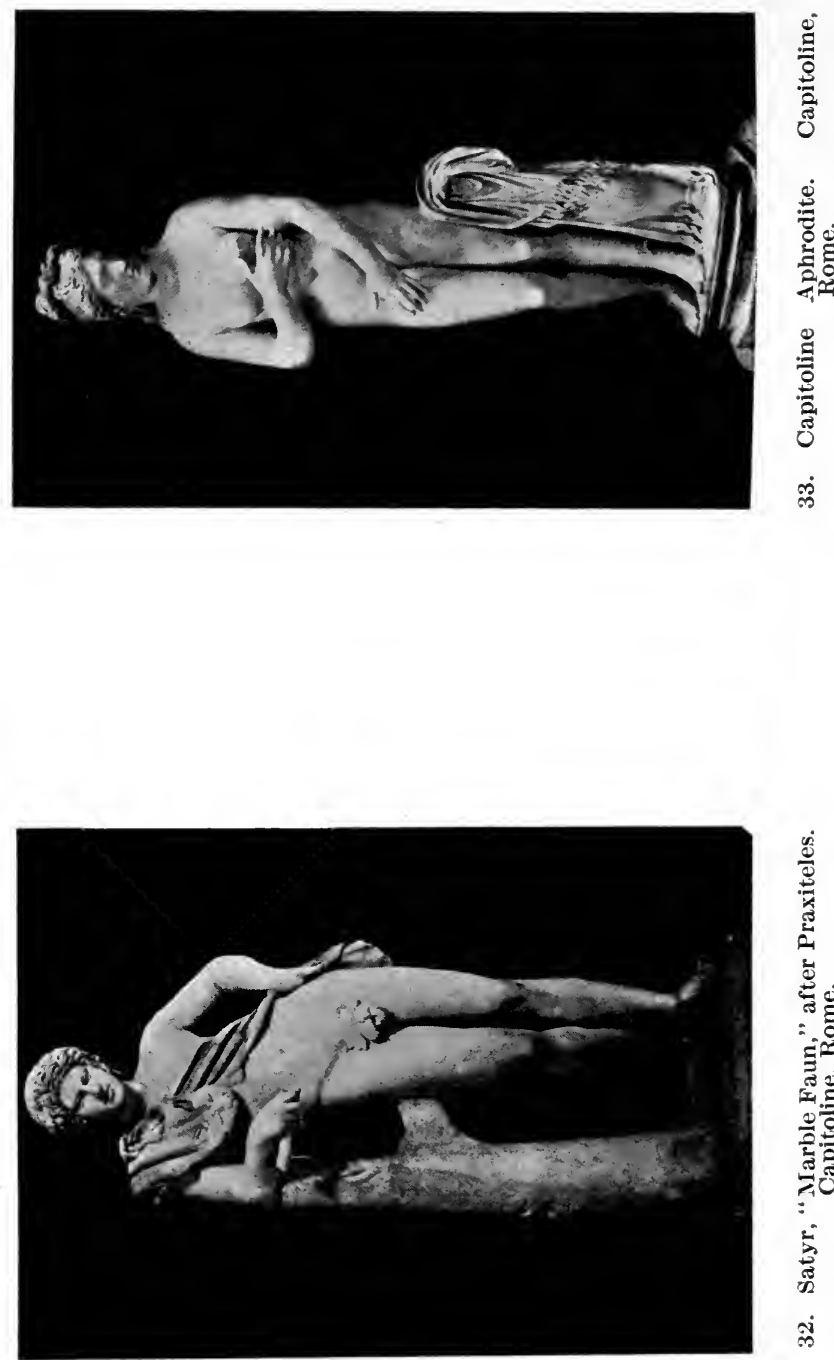


\section{CHAPTER V}

\section{ROME-THE CAPITOLINE MUSEUM}

THE "Dying Gaul," not gladiator, of the Cap1 itol (Fig. 3I), is the most prominent statue in the Museum. Most probably it is a direct copy made in Pergamon, in marble, of a figure in the famous Pergamon bronze group. This easily explains how the prostrate warrior could have received his death wound from an enemy-another figure in the group-rather than have given it himself. The wound being on the right side with the weapon withdrawn has been a strong argument against selfdestruction. This statue, found in Rome in the sixteenth century, was known as the "Dying Gladiator" until the middle of the last century. Then critics, noting the short, crisp hair, stiff mustache and twisted torque around the neck-an ornament characteristic of ancient Gaul-decided it represented a warrior rather than an athlete. The statue was complete except for part of the base and the right arm, the latter, restored by Michael Angelo (thank the great master, oh, ye people!) claims attention for its own merit.

If St. Paul could have witnessed the terrific onslaught of these northern barbarians three centuries 


\section{WHAT SCULPTURE TO SEE}

before his time, would he have said, "O foolish Galatians, who hath bewitched you? ye did run well; who did hinder you?" Like wild beasts they rushed naked into battle, terrifying not alone the more peaceable people but the warlike Romans as well. The Pergamon artists represented in bronze and marble the actual facts about the besiegers whose power they had felt. Who could look at the face and form of the defeated warrior without seeing earmarks of a cruel, unreasoning invader. There are the low, broad forehead and the flat bridged, wide nostriled nose, the high cheek-bones and lowering eyebrows of the uncivilised savage. The leathery skin, hardened still more on the sole of the foot, is that of one constantly exposed to wind and weather. There is, however, a calm dignity in these last moments of mortal agony that shows the warrior's absolute indifference to pain of body. That these barbarians from the north refused to submit to slavery in defeat is shown in the group in the National Museum (see Fig. 40).

But now let us turn to the wonderfully beautiful "Satyr Resting" (Fig. 32), a copy of a statue by Praxiteles. Could anything be in greater contrast to the "Dying Gaul"! Hawthorne's vivid word picture of this famous work, in his "Marble Faun," surpasses even a half-tone picture of it. But beautiful as it is in its complete restoration one has 


\section{ROME}

a better idea of the greater beauty of the original in a marred and broken fragment in Parian marble in the Louvre, Paris (see Fig. I I2).

Satyrs were favourite subjects in ancient art, especially to ornament fountains. They were deities of the woods and fields wandering about to give luxuriance to vegetation. Hermes was said to be their father and the Naiades their mother. At first they were covered with bristly hair, had two horns, pointed ears and goat-like feet; they loved wine and rather coarse pleasure and were feared by mortals. But in later writings they became Fauns and were gladsome, frolicsome creatures, loved by all.

Praxiteles certainly had the Faun in mind when he made the original of this beautiful creature of the Capitol. Yes, Hawthorne was right, "Neither man nor animal, and yet no monster; but a being in whom both races meet on friendly ground!Trees, grass, flowers, woodland streamlets, cattle, deer, and unsophisticated man! The essence of all these was compressed long ago, and still exists within that discoloured marble surface of the Faun of Praxiteles" (see Hawthorne's "Marble Faun," Chapter I).

The "Capitoline Venus" (Fig. 33) was found almost perfect, walled up in a niche between the Viminal and Quirinal, two of the seven hills of Rome. It is a Greek work of the very highest 


\section{WHAT SCULPTURE TO SEE}

development after Praxiteles' Aphrodite of Cnidus. The beautiful goddess is not here represented as the guardian of a temple, but as the perfection of womanly grace for the home. The statue, revolving on its base, is an exquisite example of the perfect physical woman whose every charm is nature's own. It is thought that this "Venus" may be a reproduction from a nude Aphrodite by Scopas, that was in the temple built by Brutus Gallæcus, about I33 B. C. and praised by Pliny, in comparing. it with the Cnidian Aphrodite.

The two exquisite Greek reliefs-_Endymion Asleep" (Fig. 34), and "Perseus Liberating Andromeda," representing Greek mythology-were once part of eight reliefs in the Spada Palace, Rome. Endymion's attitude of deep slumber fits well with the story that the cold-hearted Selene (the moon) loved the beautiful boy and kept him always asleep that she might kiss and caress him without his knowledge. But another version of Endymion says he was beloved of the gods and fulfilled the mission of releasing Glaucus and Scylla, who fell under the curse of Circe, according to Keats' "Endymion."

Even to-day the rock is shown off the coast of Palestine where poor Andromeda was chained. She was the innocent victim of her mother, Cassiope's vanity, but Perseus came and killed the seamonster, her captor, and then married her. But 


\section{ROME}

their troubles were not over, for a former lover appeared at the wedding-feast and demanded her as his own. Her father, Cepheus, replied:- "You should have claimed her when she lay bound to the rock, the monster's victim. The sentence of the gods dooming her to such a fate dissolved all engagements, as death itself would have done." This did not satisfy the rejected lover and only when Perseus, with the Gorgon's head, turned him and his followers to stone was he silenced. After death Andromeda was placed among the stars.

As we stand before the "Bronze Wolf," in the Capitol (Fig. 35), we feel that charm of mystery about the bronze animal that shrouds the whole story of the founding of Rome by the twin boys, Romulus and Remus. The wolf is surely of Etruscan workmanship, but when done and by whom, who can tell? The design is crude and yet wonderfully realistic. No writer mentions the wolf before Cicero and Virgil's time-the first century B. C. The latter alludes to it in the eighth book of the Eneid. He says:-

"By the wolf were laid the martial twins, Intrepid on her swelling dugs they hung;

The foster-dam lolled out her fawning tongue:

They sucked secure, while bending back her head, She licked their tender limbs, and formed them as they fed."

The last statement is probably poetic license, as [67] 


\section{WHAT SCULPTURE TO SEE}

the wolf stares straight ahead. Cicero, in one of his orations to Catiline, mentions a little gilt figure of Romulus as having been struck by lightning and intimates that his hearers would remember the group as it stood in the Capitol. As there is a broken place in the hind leg of the wolf, it is probable that this is the one to which the great orator refers. The present children were added in the fifteenth century by Della Porta and are entirely lacking in the simplicity of technic and naive conception of the wolf, their foster-mother. Simplicity and naïveté are characteristics that marked Etruscan art. Those early artists followed nature and were not imitators.

This bust of "Socrates" (Fig. 36) is one of the best of the ideal portraits of the famous Greek philosopher. Socrates (about 470 to 399 B. C.) was a sculptor himself and the son of a sculptor, yet there are no authentic likenesses of him, the busts inscribed with his name were made after the vivid descriptions of Plato, his favourite pupil. But during excavations on the site of the Theatre of Dionysos, rebuilt the last of the fourth century B. C., was found a colossal cowering silen, probably an architectural support, with a face very like the busts inscribed to Socrates. As that great thinker was said to have had a silen face, possibly this ideal portrait in the Capitol is not far from a real likeness. Silenos, the son of Hermes, was the school- 


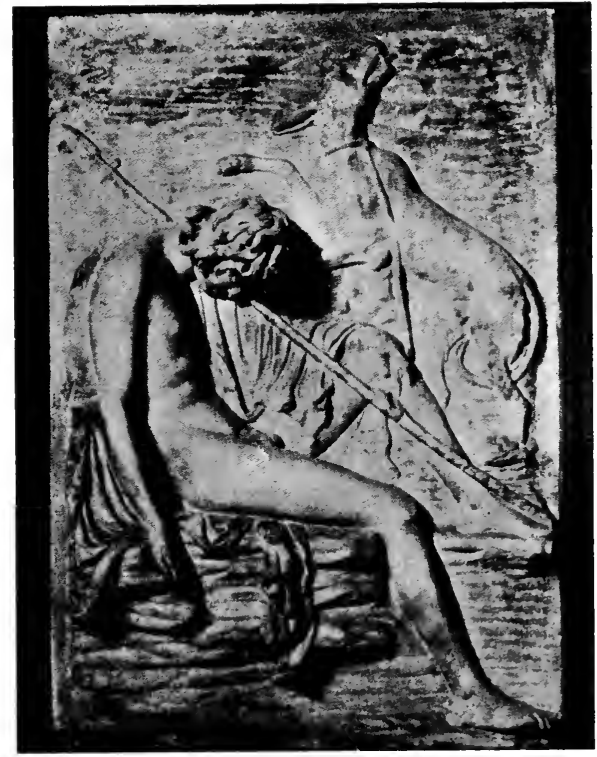

34. Endymion. Capitoline, Rome.

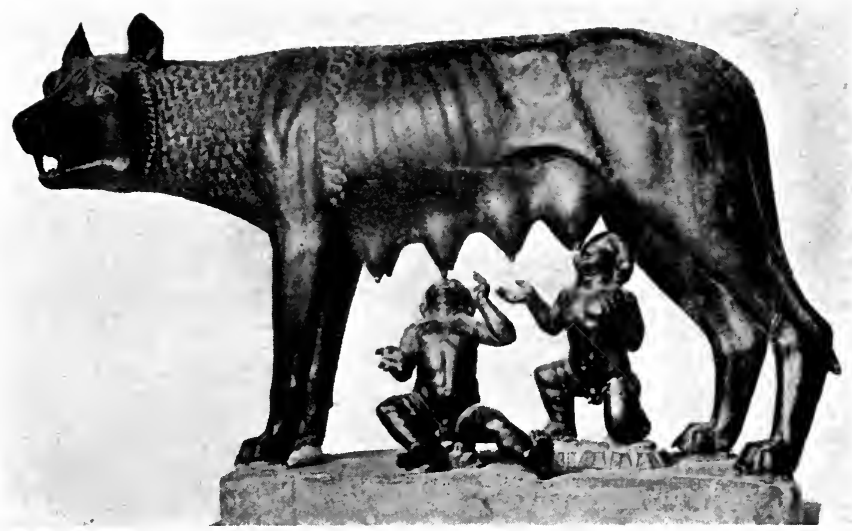

35. The Wolf. Capitoline, Rome. 


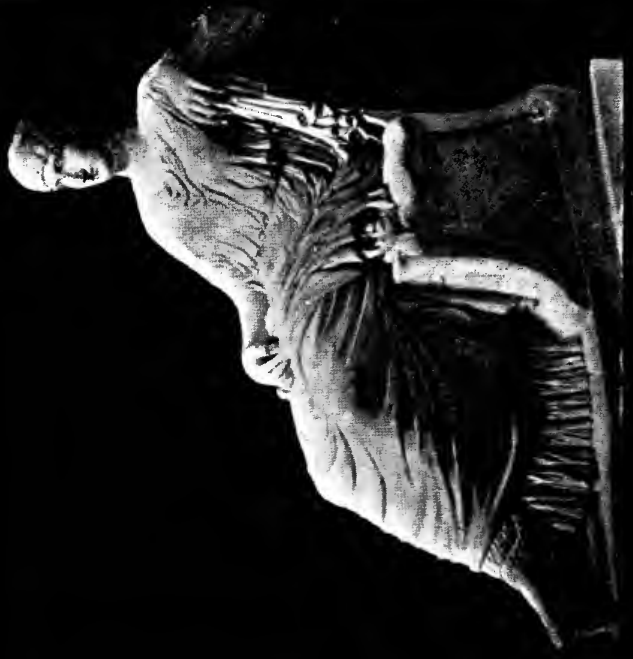

हี่



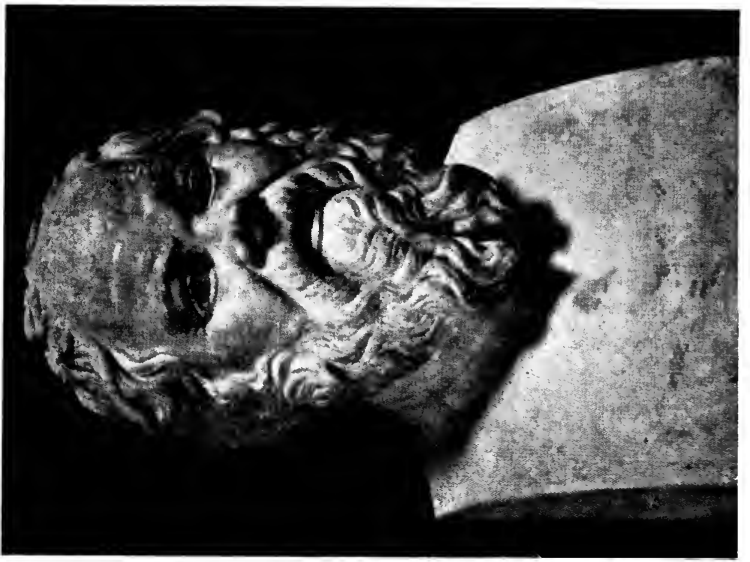

:

$\dot{0}$ 
master and foster-father of Dionysos (Bacchus). He was a fat, jolly old man, usually drunk, but withal an inspired prophet.

The beauty and calm dignity of this "Sitting Statue" (Fig. 37) certainly lead one to believe that it represents Agrippina, the youngest daughter of Agrippa and Julia. No empress in those troublous days, between the old dispensation and the new, showed greater wisdom or was more renowned for virtue than Agrippina. She was the wife of an emperor, Germanicus, and the mother of an emperor, Caligula. Accompanying Germanicus in his campaigns, she kept in close touch with all his plans and at one time on the Rhine, the emperor being absent, her presence of mind saved the army. A defective bridge threatened disaster, but she quickly took command and averted the danger.

Germanicus was murdered in Asia, and when Agrippina returned home with his ashes, the tenderest sympathy and most profound respect were shown her along the way, and in Rome she was greeted with the greatest honour by all the people. In A. D. 30, she was banished to the island of Pandataria by the jealous hatred of Tiberius. She died there, A. D. 33, probably by voluntary starvation-fortunately before the development of the horribly wicked side of her son, Caligula's, nature (see page 38 ). 


\section{CHAPTER VI}

\section{ROME-NATIONAL MUSEUM}

\section{HE National Museum building is part of what 1 was once the gigantic Baths of Diocletian-} baths so tremendous that three thousand bathers came to them daily. Though named for Diocletian they were simply completed during his reign, A. D. 305-6; the actual work of building is ascribed to condemned Christians. They began to fall into decay as early as A. D. 4 IO.

The Museum contains antiques from recent finds in excavating public property in Rome, and from other museums, private villas and palaces. Some of the statues were put here temporarily from the Museo Boncampagni several years ago.

A work that attracts almost immediate attention on entering the room where it stands is "The Birth of Aphrodite (Venus)" (Fig. 38). The relief, on one side of a marble throne intended for a colossal Aphrodite, shows the goddess just rising from the sea and two handmaidens, standing on the rocky coast on either side, raise shielding drapery before the nascent Aphrodite. Archaic it certainly is but with a realism that is charming. Look

$$
\text { [70] }
$$




\section{ROME}

how tenderly the helping hands guide and welcome the stranger and how childlike is the uplifted, expectant face. The wide-set breasts (of course too wide for nature), expanded chest and spread-out arms plainly tell the story of lungs adapting themselves to the rarer density of the new element. 'The birth of Aphrodite was a familiar subject in Greek art. Pheidias used it as one of his subjects on the low pedestal for the seat and footstool of the great Zeus at Olympia; and Botticelli, following the spirit of classic art, painted his famous picture of "Venus Rising from the Sea."

The marble throne on which is the relief of "The Birth of Aphrodite" was found in the Villa Ludovisi, in 1886 , just where stood the ancient temple of Venus Erycina; but when the throne, with its quaint decorations, was made is uncertain; the work, however, points to a developed archaic art.

Another relief in the same room of still greater interest is the so-called "Dying Medusa" (Fig. 39). The head, in very high relief, about eight inches, is that of a strong, beautiful woman at the moment when the heart has stopped and the features are setting in death. The dropped eyelids conceal the glassy eyeballs, the nose has whitened and the exquisite mouth setting into eternal silence-and yet how beautiful, more like sleep than death! The hair, tossed and blown as by a power 


\section{WHAT SCULPTURE TO SEE}

within itself, has the appearance of restless, wriggling snakes aimlessly reaching out over temple, cheek, chin, and neck. If this relief was intended to represent Medusa, the artist has made Athena's curse more real in suggestion than when actual hissing serpents are shown.

You may remember that Medusa was once a beautiful maiden with hair that was her glory, but Athena, who would brook no rival in beauty, changed her ringlets to serpents, destroyed her charms and placed her head in the centre of her breastplate.

When comparing this relief with the figures of the Pergamon frieze the theory of the Medusa head seems improbable. When found, this relief, an original, was badly broken-most of the nose, neck and chest were gone-so possibly the head belonged to a powerful woman, a beautiful woman dying. Whether the relief is a "Dying Medusa," or a "Dying Woman," it is a marvel of exquisite beauty and probably points to Pergamon's altar as its original setting.

We now turn to a group "The Galatian and his dying wife" (Fig. 40), in all probability a marble copy made in Pergamon, of the bronze original on the Acropolis of Pergamon. The fine-grained marble, from Fauni, a small island on the Asia-Minor coast, is the same as that of the "Dying Gaul" (see Fig. 3I). The two pieces were together in the

$$
\text { [ } 72 \text { ] }
$$




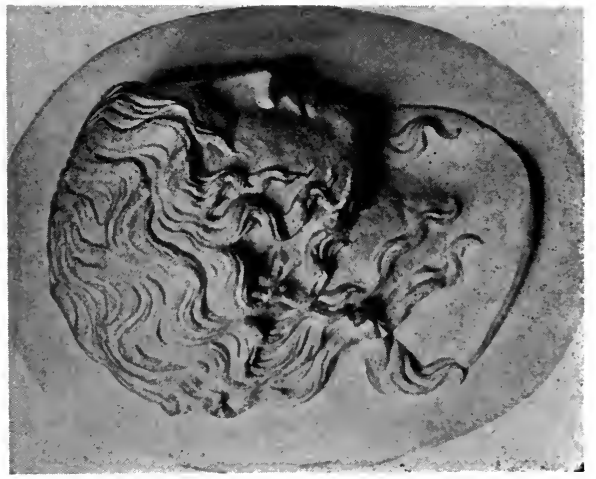

(1)

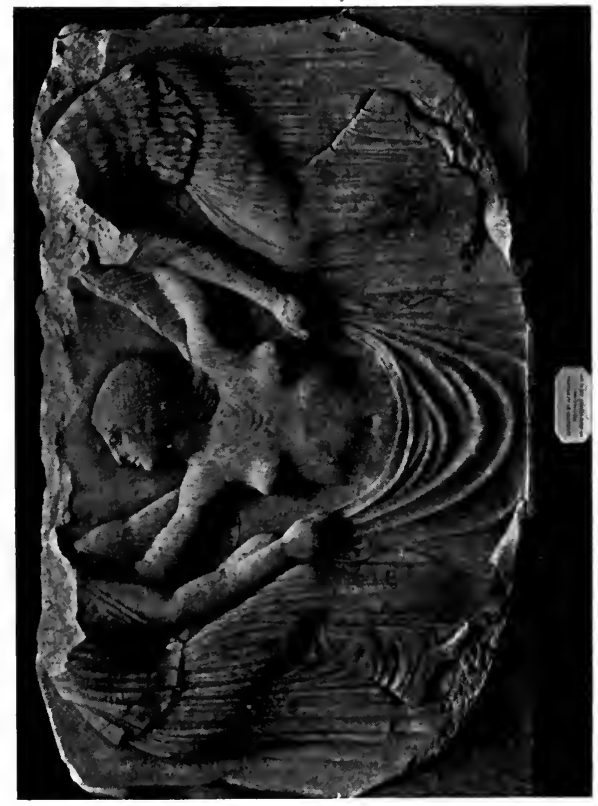

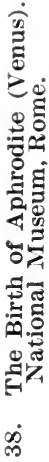




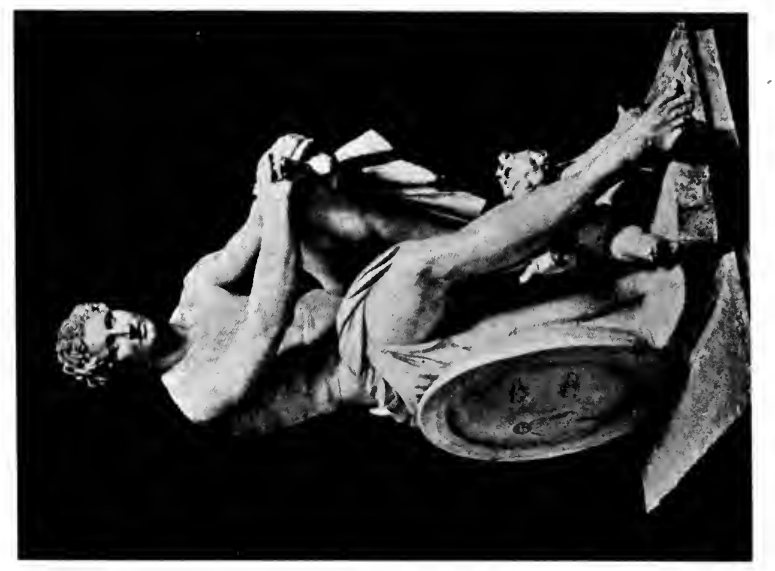

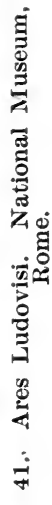

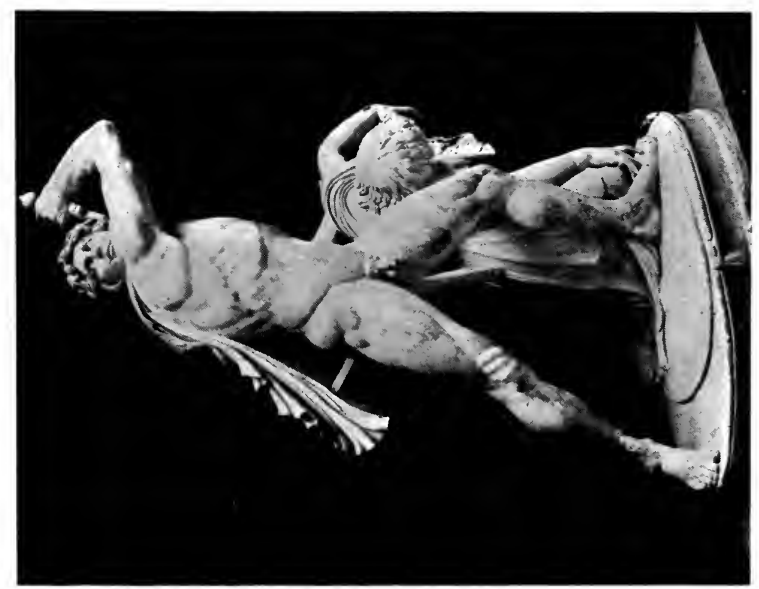

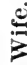

ลำ

四

हี่

สื

荚总

敢

음

密芯

氶

$\stackrel{0}{+}$ 


\section{ROME}

possession of Cardinal Ludovisi in 1622 , and may have been found on the site of the ancient Gardens of Sallust, the Cardinal's new villa. It is a pity that the two pieces could not now be together in the same museum.

Unfortunately the warrior's right arm, in this group, is restored too low. The side view shows his rugged face set in stiff hair, with upper teeth showing, and hard set features very similar to those of the Dying Gaul. The fierce warrior, hard pressed by the enemy, escapes for a moment, but realising that slavery is before him and his wife, instantly takes the life of his companion and plunges the sword into his own neck. His backward look of savage triumph and his tender grasp on the arm of his sinking wife are so tremendous in import that one is filled with horror and grief over the tragedy.

Our knowledge of the Pergamon bronzes and the Athenian marble copies, the latter sent as thank offerings by King Attalus, is still very fragmentary, though the excavations at Pergamon and Athens have brought to light pedestals and bronze bits of drapery and fingers, and broken marble statues, which give us an understanding of Pergamon art undreamed of fifty years ago.

The statue of "Ares (Mars) Ludovisi" (Fig. $4 \mathrm{I}$ ), at one time was thought to be a reproduction of a work by Scopas (fourth century B. C.), but 


\section{WHAT SCULPTURE TO SEE}

his face is too Lysippian in expression to belong to the older man; then too, the little Eros (Cupid) playing with his armour gives it more the spirit of the age of Alexander, which brings the statue nearer the third century B. C. Certainly the pensive attitude of the god of war accords better with dreams of love than of war-possibly his thoughts are with the beautiful Aphrodite, the goddess he admired above all others. Ares, or Mars, was the son of Zeus and Hera (Jupiter and Juno). He was the most highly revered god in Rome next to Jupiter and was thought to be the father of Romulus. He was usually spoken of as Father Mars and, being the god of war, war itself was often called Mars.

Goethe wrote of the bust "Juno (Hera) Ludovisi" (Fig. 42), "No words can give any idea of it; it is like a poem of Homer." Beautiful in its calm repose; satisfying in its quiet strength; restful in its reserve power and captivating in its queenly bearing. If only the whole statue had been found-this bust was never intended to be alone-what a superlatively magnificent work of art it must have been-for magnificent it is in its fragment.

Ancient writers termed Juno the "ox-eyed goddess," but why, it is hard to conjecture. Antique statues of Hera represent her as far-seeing, stern and jealous, often with her eyes narrow and far 


\section{ROME}

apart, even running into the temples, thus giving the impression of an all-seeing vision.

Hera, the queen of the gods, was the wife and sister of Zeus. She was the only goddess who was really married, so was patroness of nuptials-and was the mother of Ares (Mars). Constantly jealous, she kept her all-seeing eyes ever on Zeus, and to good purpose too, for that fickle god was prone to make love to every pretty face. The trials of Hera and the love-affairs of Zeus were never ending in number and variety.

The "Bronze Figure of a Pugilist" (Fig. 43), is not attractive as a subject, but as an original of the Hellenistic period, from Alexander the Great until about roo B. C., it is an admirable example. The carefully worked out details, as in the metal hooks fastening the leather bands, the marred and battered face and flesh, reminders of the fight, show no pettiness in handling. Possibly the pugilist's open mouth is in speech with an attendant, but more likely it indicates a stupid satisfaction as he turned his head to the applauding multitude. Verily, the stamp of the pugilist changes not with the passing of centuries!

Near this seated figure is another bronze statue of a "Man leaning on his staff," probably a brother pugilist-I suppose they formed a brotherhoodthat stands for the best art of the Alexandrian period. 


\section{WHAT SCULPTURE TO SEE}

But one of the most beautiful fragments in the museum is the "Marble Statue of a Kneeling (?) Youth" (Fig. 44), found in Nero's Villa at Subiaco. The slender, boyish youth seems to be gliding over the ground with long strides. His left knee almost touches the earth-the block is simply a support for the marble; his head is thrown back, his left arm is bent to the right; the hand must have rested on the right leg, where is still a broken fragment. The right arm, stretched upward, must have had the open hand turned outward to ward off an obstruction, which will account for the bend in the left side. Though no definite name has been given this youth, the statue is recognised as a Greek original of very great merit. Few antique marbles express living flesh so vividly; the healthy blood seems to make the strong, young flesh fairly tingle under the soft yellow surface. One realises in standing before this fragment that a master hand has touched it. The youth all but moves in his anxiety to be off. 


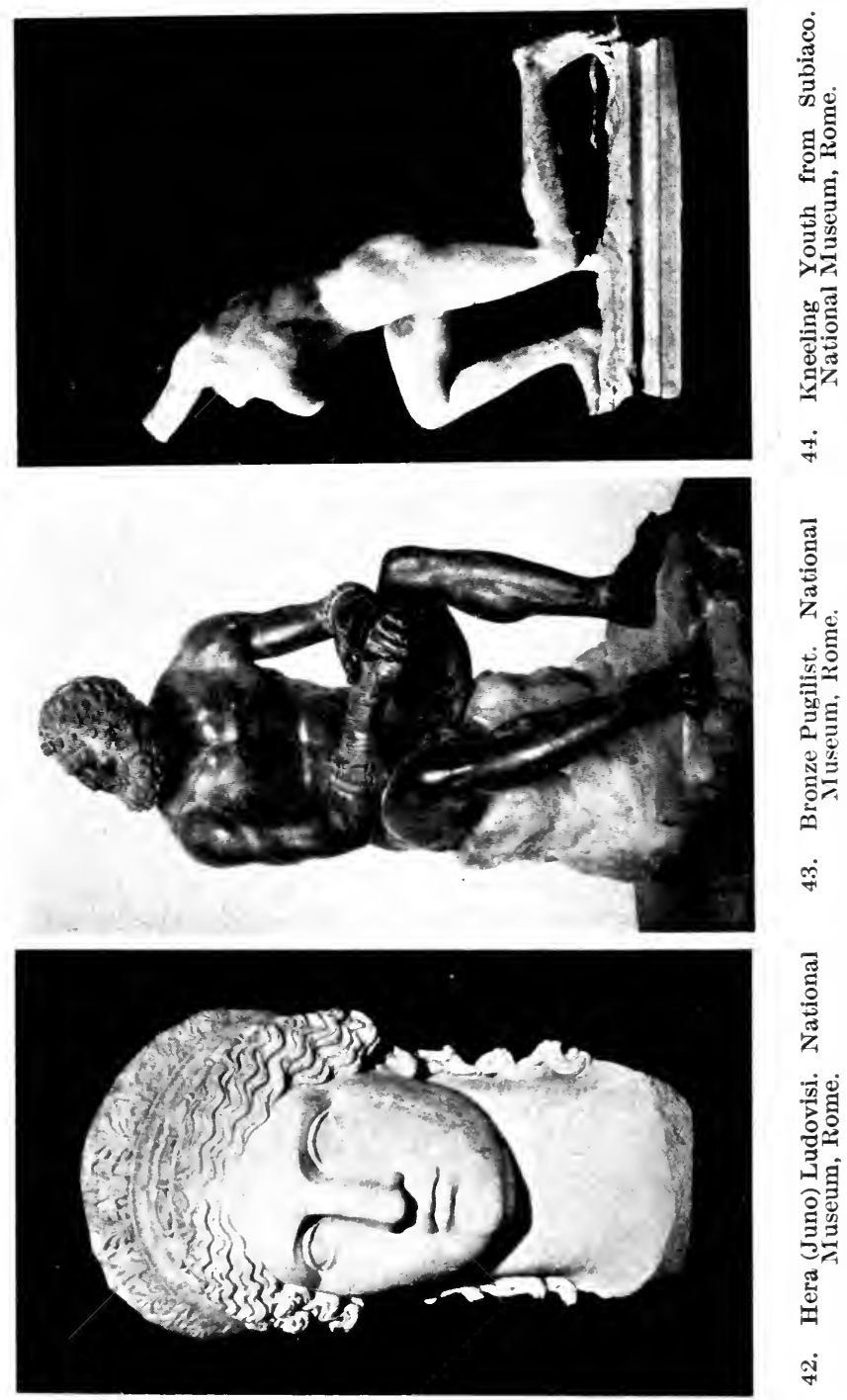




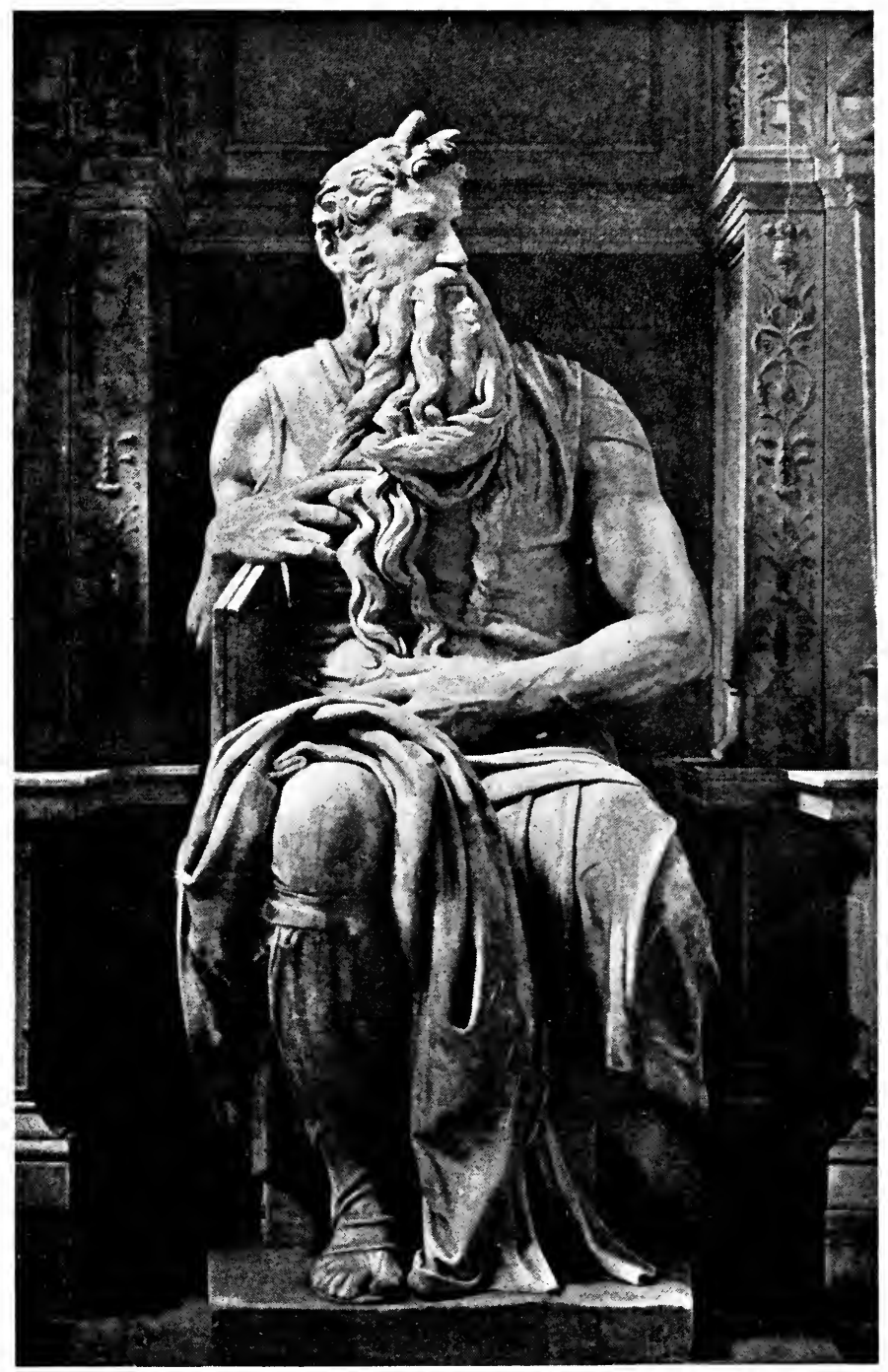

45. Moses. By Michael Angelo. s. Pietro in Vincoli, Rome. 


\section{CHAPTER VII}

\section{ROME-MISCELLANEOUS}

A S we stand before Michael Angelo's "Moses" A (Fig. 45), in San Pietro in Vincoli, it is hard to get a just idea of the majesty of the statue, placed as it is on a level with the eye. The statue was intended to be at least fifteen feet above the floor. When the young sculptor came back to

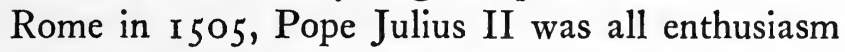
over a colossal mausoleum to himself to be placed in St. Peter's, and gave the commission to Michael Angelo. Then began the forty-five years of torment to the artist over this tomb for the touchy, vacillating pontiff, and in the end only four statues were completed of the colossal monument-the "Moses," "Victory," and the two "Captives" (see Figs. I 20, I2 I).

When the master made these great masterpieces he used no plaster model; fixed no points of length, width and depth, but with a rough sketch to find the extreme points of his composition on the marble block, gave his attention to the statue hidden within. With chisel and mallet he set to work to free the prisoner, following the barest charcoal outline traced on the marble. Surely this sculptor was a 


\section{WHAT SCULPTURE TO SEE}

prophet of God in his understanding of the Old Testament heroes! Could not this "Moses" have talked face to face with the Almighty. His conception of the mighty leader, ready to spring from his seat in indignation at the idolatry of the Israelites, is so far above our own puny thoughts that we feel little and insignificant in his presence. Looking at the statue closely, the proportions do seem inaccurate in the small head and big torso and limbs; also the piled up folds on the perfect knee are incongruous at close range, but if the statue were given its rightful place these irregularities would disappear. The horns refer to an ancient reading of Exodus xxxiv. 35 .

The symbolic statues on the left of Rachael, meditation, and on the right Leah, active life, are Michael Angelo's, though probably not done entirely by his own hand.

Michael Angelo was twenty-one when he came to Rome the first time. Though he stayed but four years- I 496 to I 500-yet during that time he made a group of statuary that linked him with the classic Greek art of eighteen centuries before. His "Pietà" (Fig. 46), in St. Peter's, surpasses all other "Pietàs" ever portrayed in marble or on canvas-not that the conception is original for other artists have used similar attitudes. Michael Angelo has wrought into this group all the pathos of the Gospel story without losing sight 


\section{ROME}

of the perfect physical beauty of the God-man and His Virgin Mother. But the critics of Rome objected that the virgin was too young. The sculptor replied: "Don't you know that chaste women keep their youthful looks much longer than others?" Not satisfied, they criticised the Son as too old. "I wanted to show," he answered, "that he really took upon him human flesh, and that he bore all the miseries of men, yet without sin."

That Michael Angelo understood perfectly the physical law of rigor-mortis is shown in the limp figure of the dead Saviour. Even the folds of the Virgin's robe that fall away from the band across the breast and from under the body on her knees, are not more flexible than are the limbs of her divine Son. Look at the joint of the right shoulder and the drop of the legs; in fact the whole body expresses inertness, the end of all physical power. Again and again we are drawn to the group, the pity of it all appeals to our very heart of hearts.

In S. Maria sopra Minerva is Michael Angelo's "Christ with the Cross" (Fig. 47). The statue was designed by the master, then put into the hands of his assistants to finish. The figure is so marred by the bronze drapery that Michael Angelo's original idea of a "Risen Lord" is all but lost. The stiff loin-cloth gives the effect of a stocky, gross figure-an entirely physical resurrection-that is 


\section{WHAT SCULPTURE TO SEE}

foreign to the great master's spiritual insight of Redemption.

The Arch of Titus is one of the most unique monuments in Rome. One wonders if Emperor Titus realised what he was doing for the world when he had the "Seven-branched Candlesticks" (Fig. 48) carved on this famous arch of triumph. This relief is the only picture showing the exact shape of that unique piece of furniture of the Old Tabernacle and of Solomon's Temple. When Titus came back to Rome, after the destruction of the Holy City, in A. D. 70, he not only brought twelve thousand Jews as captives but the furnishings of the Temple in Jerusalem. To celebrate this great victory Titus compelled these Jews to march in triumphal processions and, as years went on, he forced them to work on the arch that was to stand as a memorial of their defeat-the Arch of Titus on the Via Sacra, at the foot of the Palatine Hill. For years after the arch was completed (Titus did not live to see it finished) an annual celebration was held, and the Jews were obliged to form in line and march through the arch to keep in mind their overthrow and to humiliate them in the eyes of the Romans.

The arch was originally built of Pentalic marble but only the interior casing with its precious reliefs is left to-day. On one side in low relief is the "Seven-branched Candlestick," borne by a tri-

[8o ] 

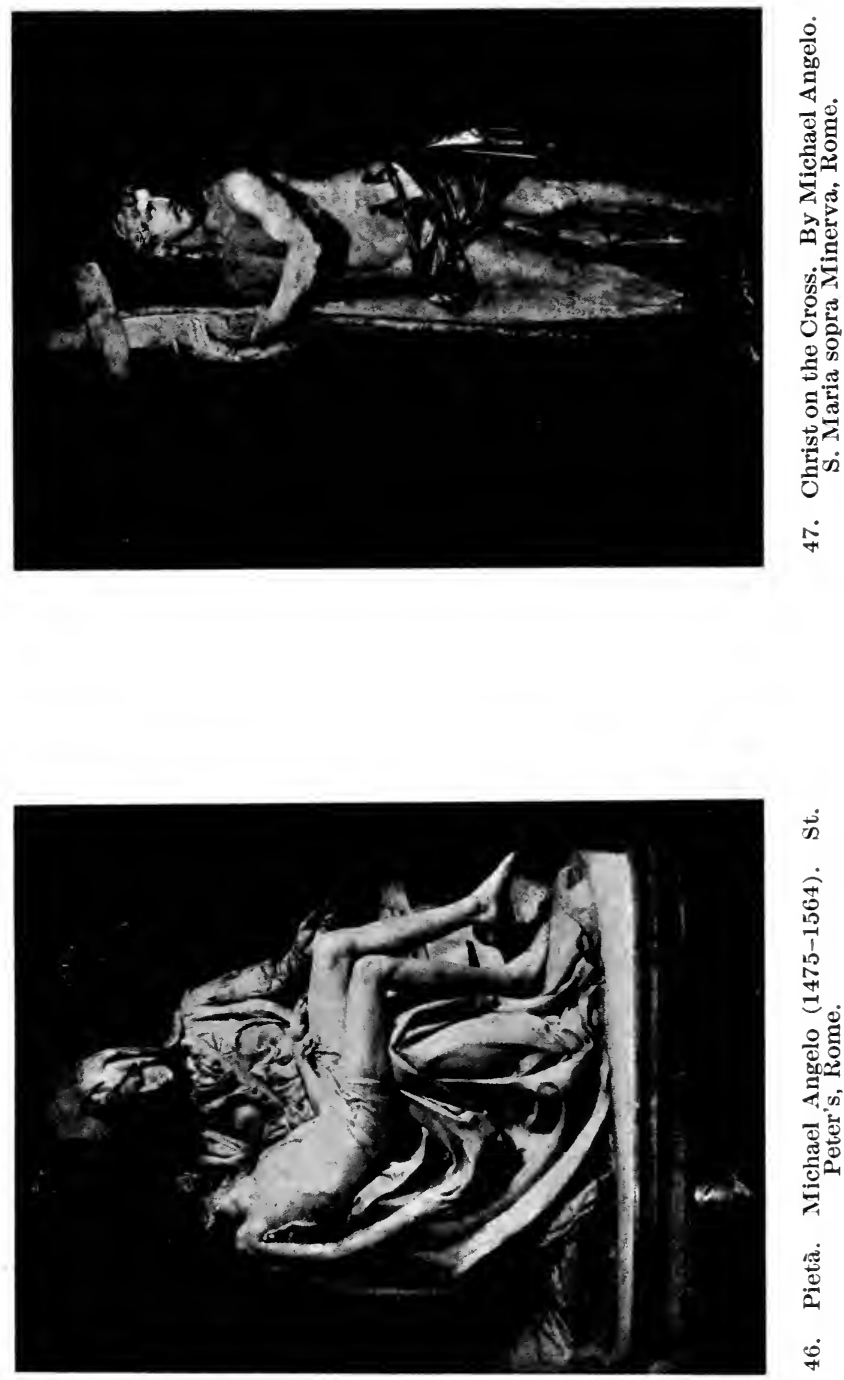

落 


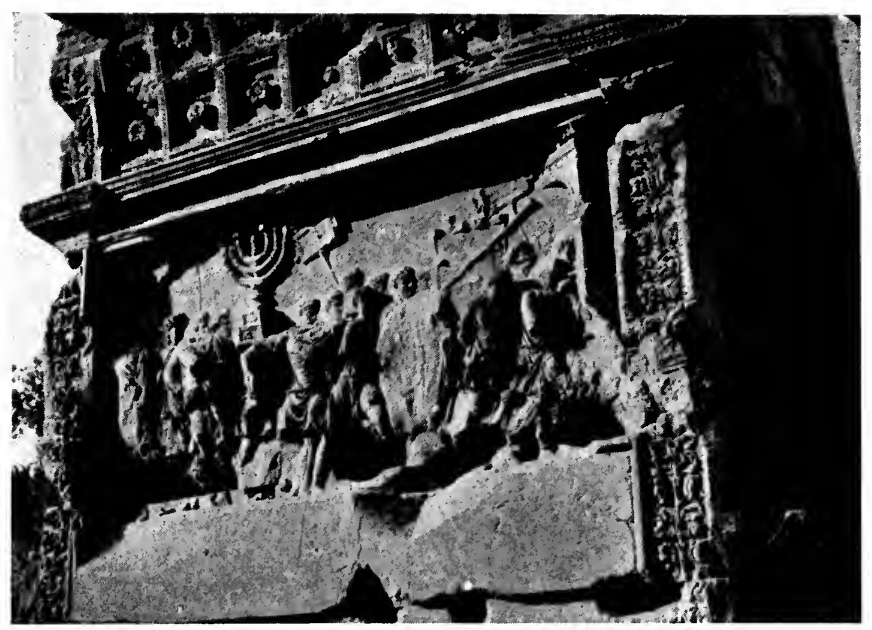

48. The Seven Branched Candlesticks. Arch of Titus, Rome.

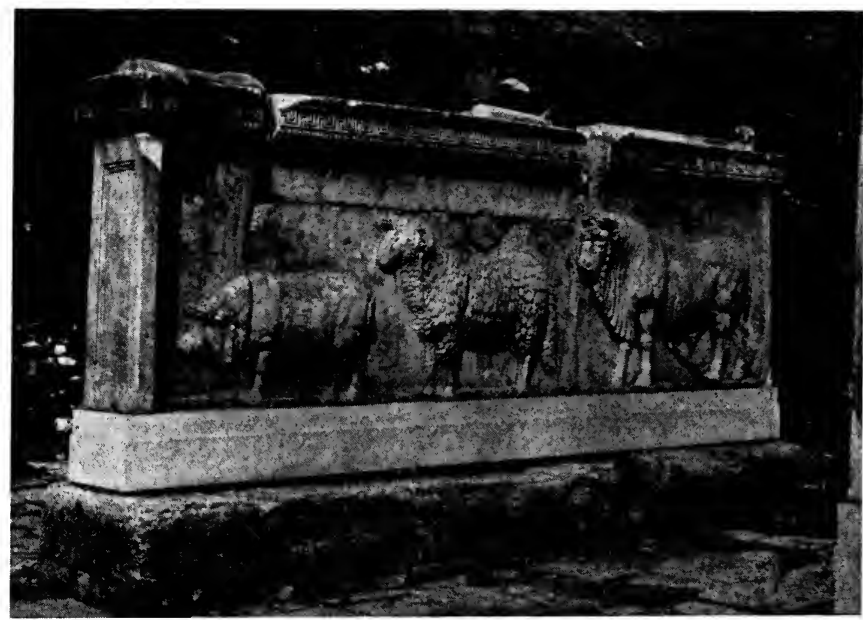

49. Relief of Pig, Sheep, and Bull. Roman Forum, Rome. 


\section{ROME}

umphal procession. Until recently it was believed that the candlestick and other furnishings were thrown into the Tiber, but research has proved that these spoils were first placed in the temple of Peace, Rome, where they remained nearly four hundred years. Then they were carried to Carthage by the Vandal King Genseric; after nearly a century they were taken to Constantinople, and from there were sent back to the Christian church at Jerusalem. They were again brought to notice A. D. 6I4, when Khosroes, king of Persia, took Jerusalem and claimed them as part of his spoil. Since then all trace of them has been lost.

Wandering in the Forum Romanum one finds many interesting statues and reliefs, turned up by the excavator's shovel, that help to form vivid pictures of the decorations on temples, colonnaded courts and public buildings that once stood in the famous market and meeting-place. The relief of a procession of a "Pig, Sheep, and Bull" (Fig. 49), on a balustrade, fully justifies Raphael's expectations. He proposed, as early as $15 \mathrm{I} 9$, to restore the Forum and reclaim the art treasures buried there. The work was really begun, but nothing was brought to light and the plan was dropped for three centuries, until the enterprise of the nineteenth century again began the work. When one realises that the ancient pavement of the Forum was at least forty feet below the present street level, one

$$
\text { [8I ] }
$$




\section{WHAT SCULPTURE TO SEE}

is not greatly surprised at the time taken to uncover the hidden treasures. Of the statues brought to light, there are a number of interesting though broken ones now standing to the right, about half way to the arch of Titus, and among the number one of the "Prefect" (Fig. 50), that compares favourably with the best art of the classic Roman period.

In the Museum of the Lateran is a "Marsyas" (Fig. $5 \mathrm{I}$ ) that, if it had been properly restored, would be one of the best suggestions of Myron's famous "Marsyas," mentioned by Pliny. The statue was found in an ancient studio in Rome, surrounded by other pieces, some of them with the sculptor's tools still in them. In this figure Marsyas seems to be dancing to the music of his castanets. This is an erroneous idea of the satyr, if the stories about him are true. Athena loved music and invented the flute. But when Eros, the little fraud, saw her he laughed at her puckered mouth and funny face. This she could not stand, even from so lovely a mischief, so she threw the instrument from her. Marsyas, seeing it fall on earth, ran and picked it up and began making music so ravishing that he even challenged Apollo--the audacious satyr! Of course he was worsted in the contest and was flayed alive for his presumption. But some people believe that as he stooped to pick up the discarded flute Athena appeared be- 


\section{ROME}

fore him and he, affrighted, started back in dismay. Myron must have believed the latter story, for the face of this satyr shows more fright than merrymaking. In the original bronze there was no support, which intensified the backward leap of the frightened creature (see bronze Marsyas, Fig. I 5 I).

A portrait statue of remarkable beauty in the Lateran is that of "Sophocles" (Fig. 52). This undoubtedly is one of the very finest ancient portrait statues in the world. It is a well-known fact that Lycurgus, between 343 and 329 B. C., directed the restoration of the Temple of Dionysos, built in Athens during the fourth century B. C., and that at his proposal were set up bronze statues of the three tragedians- - Eschylus, Euripides and Sophocles. A few years ago when the Theatre of Dionysos was uncovered, on the southern slope of the Acropolis, there were found many pedestals, but so far no remnants of the statues they held. It is possible, however, that this statue of Sophocles is a marble copy of one of the three bronze originals ordered by Lycurgus. The statue was found before 1839 in Terracina, a frontier town between central and southern Italy. If this is a portraitstatue of the tragic poet, who stood as the literary representative of the age of Pericles, then we gain a little conception of how ideally beautiful in dignity of carriage, in purity of expression, in loftiness 


\section{WHAT SCULPTURE TO SEE}

of intellect, and in power of command was Sophocles! It is not surprising that such a man brought the Greek drama to the highest point of perfection, and that no writer, ancient or modern, has ever surpassed his elevation of thought and purity of style. 

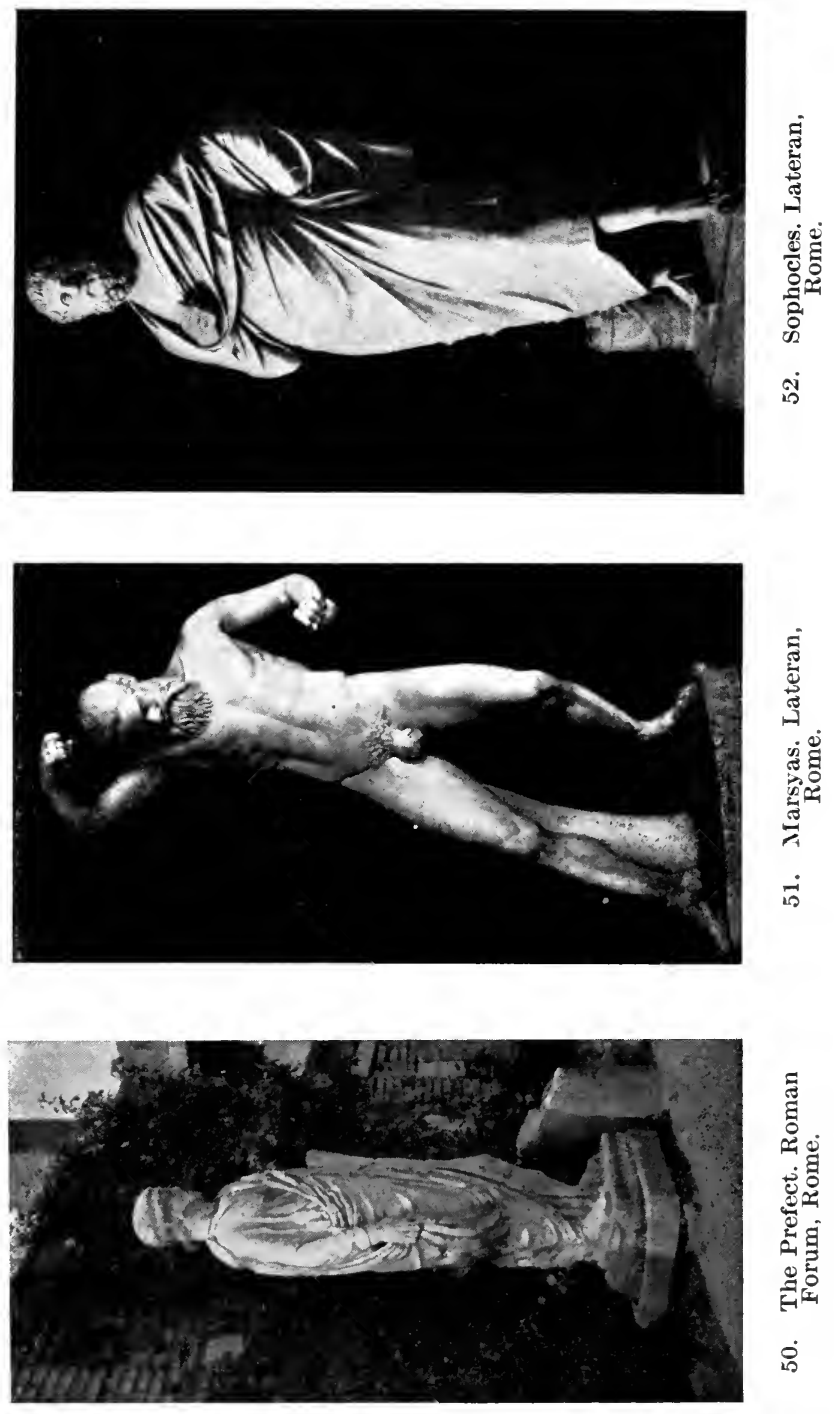


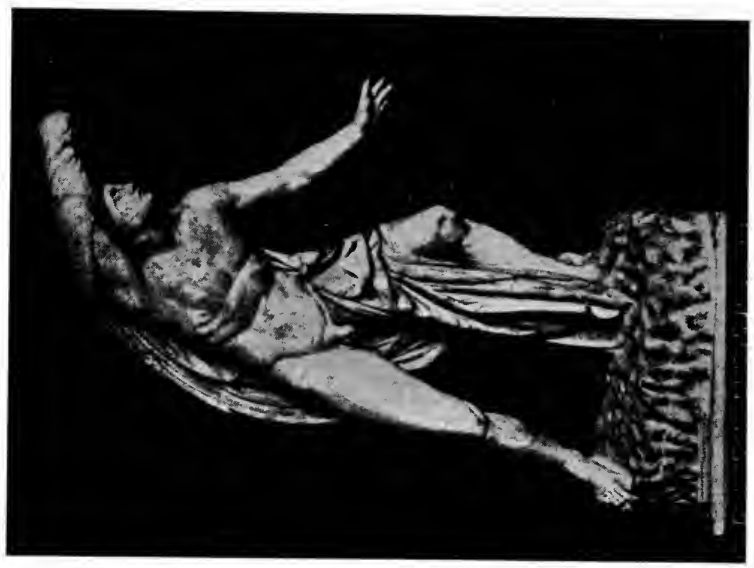

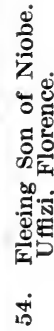

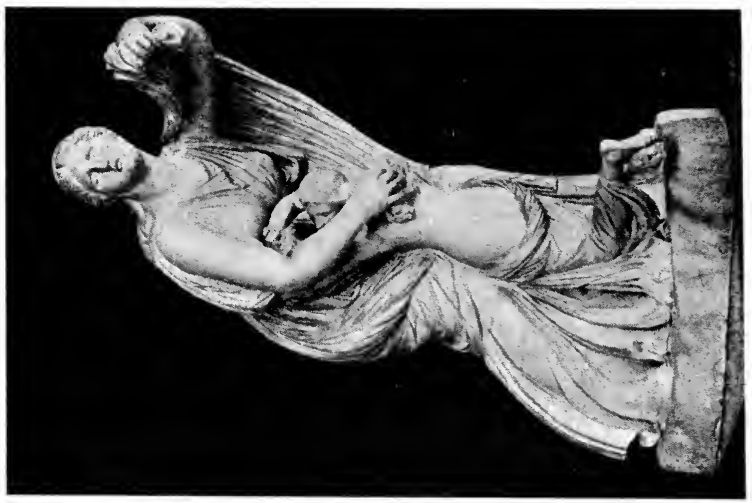

苍 


\section{CHAPTER VIII}

\section{FLORENCE-THE UFFIZI GALLERY}

THE most pathetic group of statuary in all 1 sculpture was made by Scopas in the fourth century B. C. of "Niobe and her Dying Children." Though the original is entirely lost and the fragmentary group of copies is made up on separate pieces, most of them in Florence, yet the effect even of those broken pieces is overwhelming and our hearts cry out in sympathy for the afflicted mother and her dying children. The story of Niobe is pitiful in its very humanness. What mother would not be overproud of fourteen well formed, beautiful children!

Niobe was the queen of Thebes; but it was not her position that made her vainglorious, it was her seven sons and seven daughters; it was not her pride that brought her to grief, but her boasting. The goddess Latona and her two children, Apollo and Artemis (Diana), were the special guardians of Thebes, and once a year the people paid their vows at the altar of these deities. At one of these celebrations Niobe came attired in gorgeous raiment, as became a queen, and wearing jewels of gold and precious gems. She looked with 


\section{WHAT SCULPTURE TO SEE}

anger and haughty pride on the laurel-crowned people carrying frankincense for the ceremonies. "What folly is this!" she cried, "to prefer beings whom you never saw to those who stand before your eyes! Why should Latona be honoured with worship and none be paid me? Will you prefer to me this Latona, the Titan's daughter, with her two children? I have seven times as many." Thus she went on reviling the pretensions of the goddess with her two offspring and glorying in her own strength with her fourteen, until in a perfect frenzy, she threw off all caution and exclaimed:

"Away with you from these solemnities! Put off the laurel from your brows! have done with this worship!" The people obeyed and the offering to their deities was left unfinished.

But the goddess Latona, though unseen, could hear. Her anger burned hot against such taunts from human lips. She called her son and daughter and began recounting Niobe's vauntings; scarcely had she begun to speak before Apollo and Artemis exclaimed: "Say no more, mother, speech only delays punishment," and then were off. Shielded from view by the clouds, they alighted on the towers of Thebes unseen, and soon spied Niobe's sons at their field sports. One after the other of the innocent victims was laid low by Apollo's avenging arrows. If only Niobe could have bridled her 


\section{FLORENCE}

boastful tongue in her anguish, her daughters might have been spared.

"Cruel Latona," she cried, "feed full your rage with my anguish! Yet where is your triumph? Bereaved as I am, I am still richer than you, my conqueror." Foolish woman! scarcely were the words spoken when the sisters, mourning over the biers of their dead brothers, dropped one by one as the arrows pierced them. One only remained, clinging to her mother for safety (Fig. 53). Too late Niobe pleaded, "Spare me one, and that the youngest! O, spare me one of so many!" but that one, too, fell dead.

Marvellous indeed is this pleading mother shielding her one remaining child! Plead she did, but never flinched. Even when all were gone, no paroxysms of grief overcame her. The calm repose of a terrible grief overshadowed her until her whole being stiffened and she became as stone, with only flowing tears to tell of her sorrow. And to this day she stands on her native mountain, a mass of rock over which trickles a tiny stream, symbolising her unceasing grief.

Most of the statues of the Niobe group were found outside the Porta San Giovanni, at Rome, in 1583 , and, bought by the Medici, were placed by Cardinal Ferdinand de' Medici in his villa on the Monte Pincio. In $177 \mathrm{I}$ they were transferred to Florence, and in 1794 were put in the 


\section{WHAT SCULPTURE TO SEE}

Uffizi Gallery. At first these broken pieces were thought to be originals by Scopas or Praxiteles, but since genuine Greek works have been found, these are relegated to the place of excellent Roman reproductions of an original by Scopas. Not all of the Florentine Niobe statues are the best of these reproductions, as those in the Vatican bear witness (see page 49). "The Fleeing Son" (Fig. 54), in Florence, is without the figure of the sister, but the stretched-out left arm, with its protecting hand and the shielding drapery on the uplifted right arm, both point to the Vatican group as the correct one. All the seven sons are represented in this group, but only two of the daughters; only five have ever been identified. There is some question as to there having been more than twelve children in the story.

The statue of "The Pædagog" (Fig. 55), compare it with the "Pædagog and Boy," in the Louvre (Fig. I I4), is a beautiful example of the Greek custom in high-born families of always having a pedagogue or slave attend the youngest son. In the Louvre group the right arm and hand are antique. The tender grasp of the frightened child's arm shows the loving protection the slave is quick to give his young charge. In this statue, the figure is so like the slave with the boy that he may have formed a part of the original group. Here he starts forward as though to shield the boy with his 

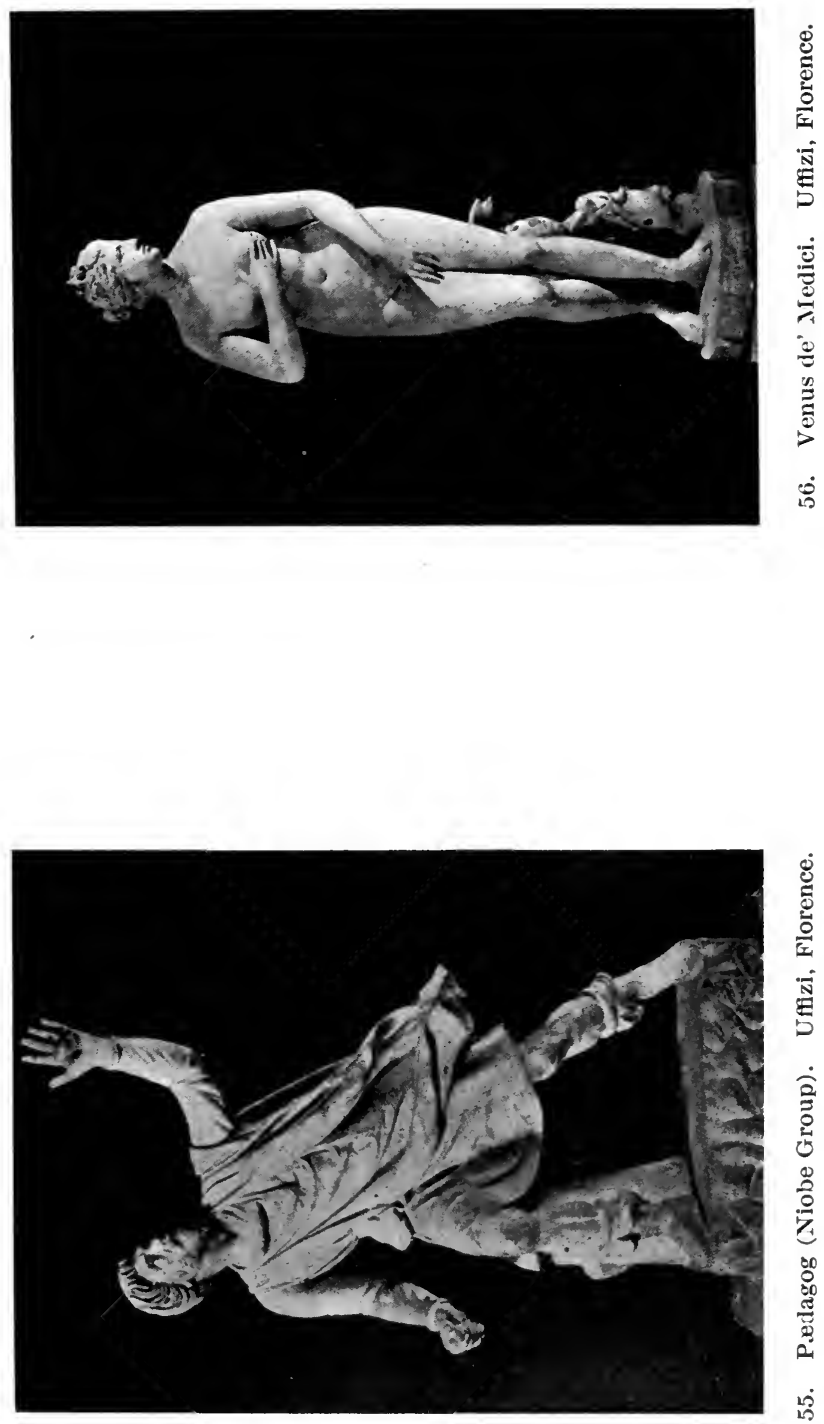

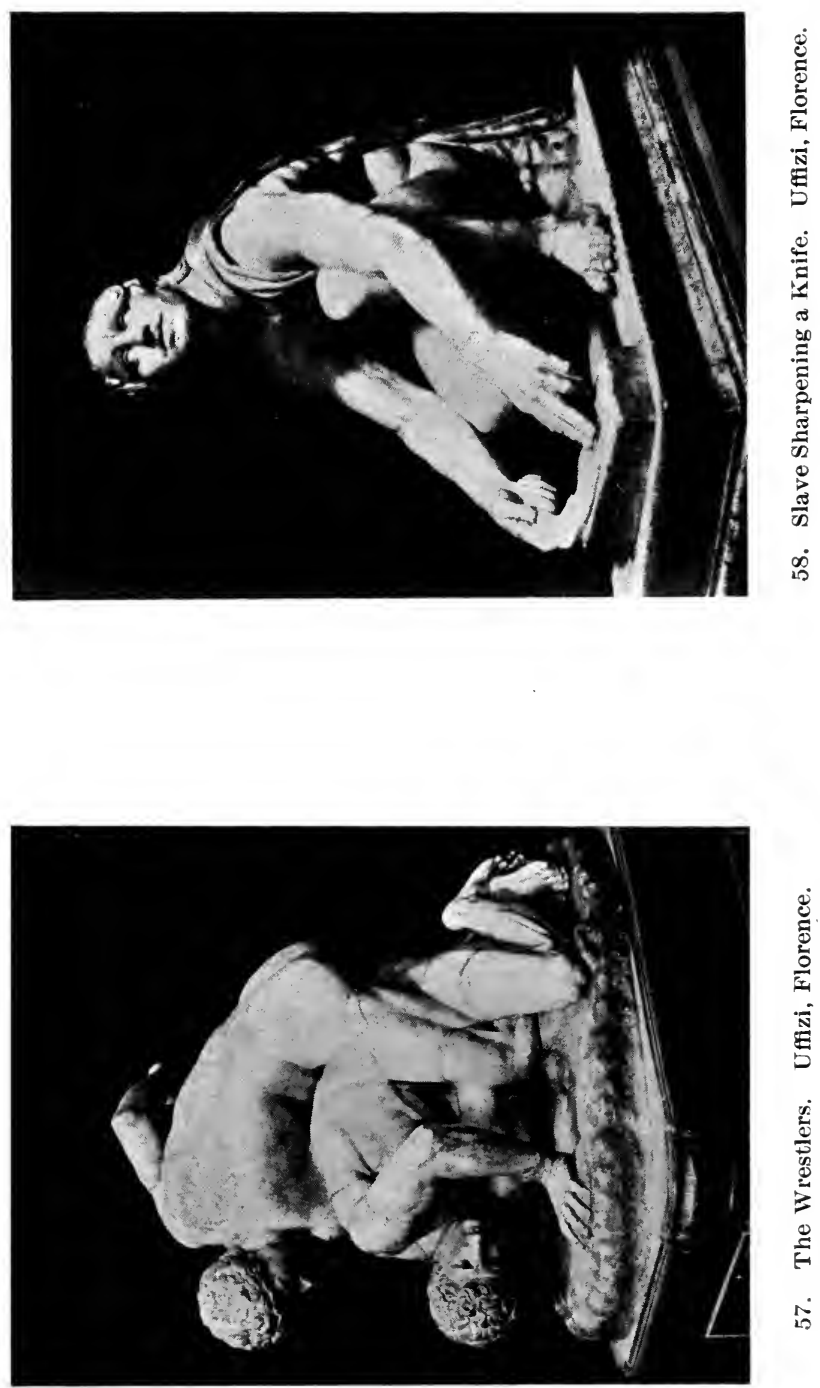

8 


\section{FLORENCE}

own body, while importuning the gods for the safety of his charge.

Let us look once again at the grief-stricken mother. There is something superb in her calm submission to the inevitable. No representation of Christian fortitude under overwhelming disaster could show more of the divine element in the human soul than is found in this pagan mother. Then too, how magnificent is her physique! She has reached the full maturity of all womanly charms. And in contrast, how wondrously sweet the girlish immaturity of the clinging child. See how the tender, quivering flesh under the filmy covering and the contracting toes of the rigid foot express the terror that fills the heart of the child. The pathos of this group brings unbidden tears, yet its exquisite beauty check their fall. Perhaps the Niobe myth originated in a terrible plague that swept over the land and rifled every home of its treasures.

In the Tribuna of the Uffizi Gallery is the farfamed and much discussed "Venus de' Medici" (Fig. 56) -a statue that has been very much overestimated as to its artistic value. It no doubt is a variation of Praxiteles' "Aphrodite of Cnidus," but how inferior the conception! The older Aphrodite having just dropped her cloak is ready to step into the sea, only she lingers a moment with a far-off look in her dreamy eyes. But here we have simply a nude figure, beautiful but a little too conscious to 


\section{WHAT SCULPTURE TO SEE}

be entirely satisfactory. The motif of definite purpose that always underlies the nude in all classic Greek art is the secret that preserves its purity of thought and execution. A goddess stepping forth for the bath with her garment fallen by her side is an entirely different proposition from the same goddess coquetting for admiration-and the Greek artist knew it.

It is still a disputed question whether the "Venus 'de' Medici" was found in the Gardens of Nero on the Tiber or in the Portico of Octavia; the inscription on it ascribing it to Cleomenes, son of Apollonius, has been proved a fabrication of the seventeenth century. When the statue was taken to Florence, it was badly broken, and after 1677 was restored by Ecole Ferrata. The lean fingers and the marred surface of the marble are evidences enough that he was not equal to his task.

The statue of the "Slave Sharpening a Knife" (Fig. 57), often called the "Grinder," is another reference to the Marsyas myth. The statue was found in Rome in the sixteenth century and belonged to the same group with the red marble "Marsyas," in the Uffizi Gallery, and possibly restored by Donatello. The slave is grinding the knife to take the skin of Marsyas after Apollo had ordered him flayed alive for his presumption. His skin was then hung in the cave at the source of the river Marsyas, formed by the satyr's blood.

$$
\text { [ } 90 \text { ] }
$$




\section{FLORENCE}

The statue in the Louvre (Fig. I IO) shows poor Marsyas bound to a tree. The two statues, "The Slave" and "Marsyas," associated together, would account for the half-grin and "I'm sorry but it must be done," expression on the Scythian's face as he prepares his knife for the cruel deed. The realism of the brutal slave and the tortured satyr place these statues at least in the Hellenistic age of Greece. They also have many points of resemblance to the Pergamon marbles and may have belonged on the Asia Minor coast.

The "Group of Wrestlers" (Fig. 58) was found on the same site with the Niobe group, near the Lateran, Rome, and at first was thought to be a part of the latter, but was finally set aside as not. The heads do not belong to the "Wrestler Group" and the legs and arms are largely modern; the right arm of the victor is certainly meaningless in its present position.

The splendid "Shepherd Dog" (Fig. 59) is a fine example of the representation of the animal in art as an animal pure and simple. The firm set legs, attentive ears, alert eyes, sensitive nose and responsive mouth are those of an intelligent watchdog, with instinct developed to its fullest extent. This dog belongs to that famous breed of shepherd dogs of Molossians, an ancient race of people who claimed descent from Pyrrhus the son of Achilles. These people were looked upon as semi-barbarous, 


\section{WHAT SCULPTURE TO SEE}

yet they became prominent in Epirus in northern Greece and in the fourth century B. C. their kings ruled that whole country.

Also note the "Wild Boar," a powerful specimen of that ferocious animal.

Quite recently a very curious discovery has been made on Benvenuto Cellini's statue of "Perseus with the Head of Medusa" (Fig. 6o), that stands in the Piazza della Signoria. It has long been known that there was a face on the back of the helmet of Perseus, but it has taken these four hundred years before any one recognised its resemblance to Cellini's own portrait. The supposition is that the sculptor took this means of identifying himself with his immortal work-a work of which Cellini in his Memoirs says, after stating that Michael Angelo was too far advanced to do such work, "Therefore I think I am justified in saying that no man known upon this earth could produce my Perseus."

The figure of Perseus was made by Cellini at the command of Cosimo de' Medici and is supposed to symbolise the violent end of the Republic of France. According to Cellini, in his Memoirs, the vicissitudes of sickness, of caprice in the duke and jealousies of "that great brute of a Bandenello," and other rivals, this masterpiece of his life was nine years in the making, and at the end scarcely the cost of the material was allowed him 

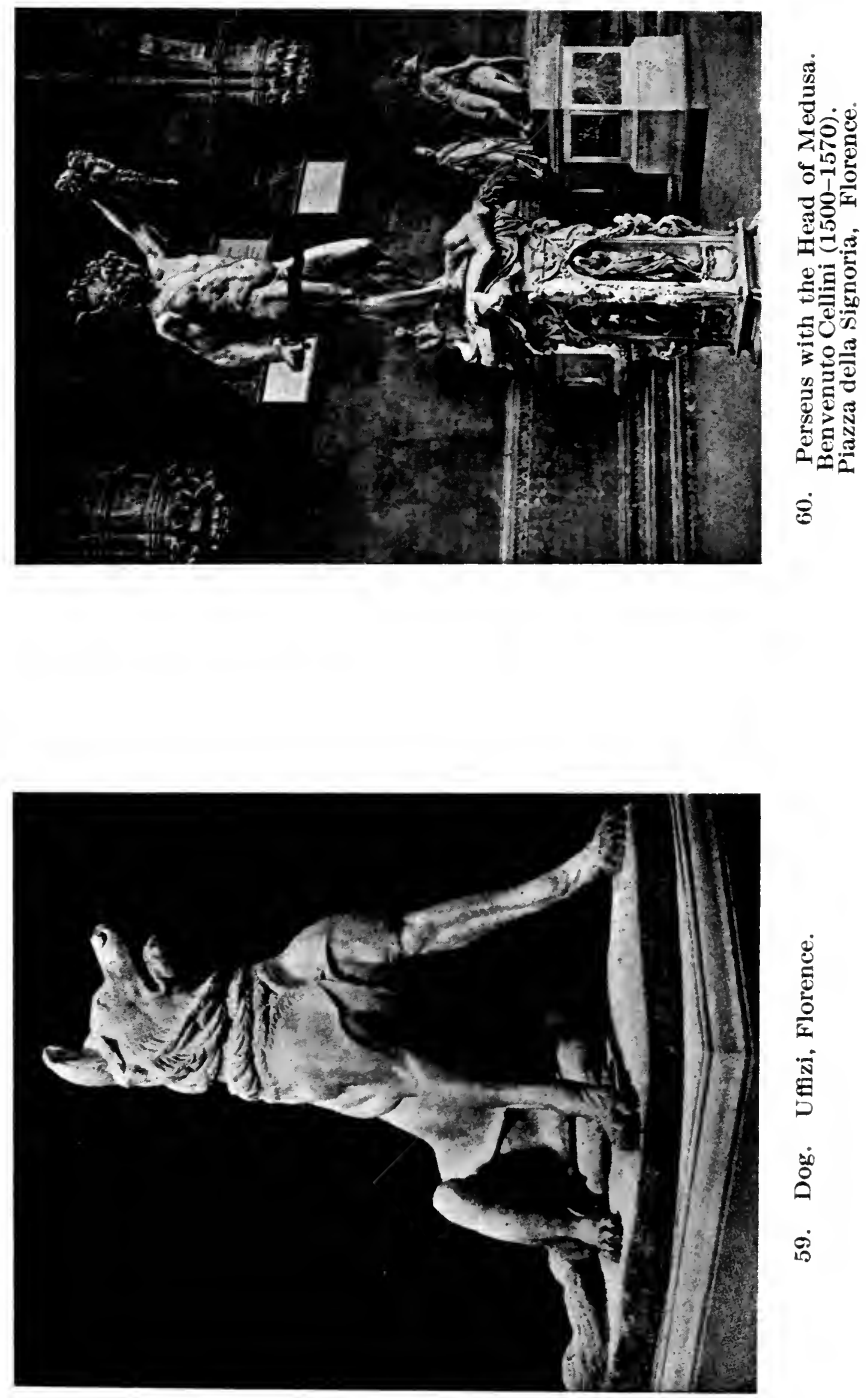


\section{,}




\section{FLORENCE}

by the duke. But Cellini, by nature a boaster, relates such marvellous stories of injustice done him that one must take his Memoirs with a grain of salt.

Perseus was the son of Zeus and Danaë. When he was born, his grandfather, warned by an oracle that he would be killed by his grandson, set him and his mother adrift in a sealed cask. They were rescued, however, by a fisherman and Perseus was brought up by Polydectes, the king of the country. When he was grown to manhood the king sent him to destroy Medusa. With the aid of Athena's bright shield and the winged shoes of Hermes, Perseus slew the monster-the once beautiful maiden now become a monster. It is at the moment of lifting the head on high that Cellini has chosen in his statue of Perseus. 


\section{CHAPTER IX}

\section{FLORENCE-MICHAEL ANGELO}

M ICHAEL ANGELO and the Medici House 1 dominated Florence in the sixteenth century and the influence of both is still felt. When the young sculptor returned from his four or five years' stay in Rome, about I500, he found the consuls of Florence agitated over a piece of Carrara marble that had lain in the yard of Santa Maria del Fiore since the memory of man. They were unwilling that the sculptor Contucci should use it, with added pieces of marble, and proposed to Michael Angelo that he make a "David" out of it alone. The huge block, eighteen feet in length, was originally intended for a prophet, but had been spoiled by some clumsy workman centuries gone by. Donatello had refused it at least a hundred years before and no one saw any possibilities in the ruined monster. But when the offer came to Michael Angelo, he at once saw his colossal shepherd king, the "David," of the Academy (Fig. 6I). He accepted the order and set to work to finish the statue in two years; working furiously, doing every stroke himself, often sleeping in his clothes to be ready for work at the first peep of

[94] 


\section{FLORENCE}

day. He had no model except a small wax one still kept in the Uffizi Gallery. "David" (Fig. 6I) was held so close in the block that the original rough surface is left on top of his head and his left foot and his right elbow scarcely escape being rough. Simple and natural stands the shepherd boy. His large hands and feet and joints show how perfectly Michael Angelo knew the anatomy of a growing boy-awkward and ill at ease except when roused to action by an inward idea.

Where to place the finished statue was quite a serious question. Such artists as Leonardo da Vinci, Roselli, Botticelli, Filippo Lippi, Lorenzo di Credi, and the aged Perugino were consulted, but finally the decision was left to the young sculptor himself. He chose the public square to the left of the entrance to the Palazzo Vecchio-possibly having in mind the advice he gave a young sculptor years a fterward:- "Do not trouble yourself about the light on your statue. The light of the public square will test its value." Donatello's "Judith" was removed from the square to put "David" in the chosen spot. The colossal statue, three times the height of a man and weighing nine tons, was drawn along oiled beams from the sculptor's studio to the square, by forty men, and under the most trying circumstances. Intrigues and jealousies were rife in Florence so that guards were necessary, and even then stones were thrown at night, but the 


\section{WHAT SCULPTURE TO SEE}

'darkness itself was a protection and no harm came to the masterpiece. For four centuries it stood in the public square with no covering save the blue sky of Italy, an honour to Michael Angelo and the pride and joy of his beloved city. At last the ravages of time compelled the citizens of Florence to place the statue in the Academy of Florence.

Let us stand before the Medici tombs in the Medici chapel and try to realise some of the tragedies that Michael Angelo worked into these marvellous compositions, especially into the "Monument to Giuliano de' Medici," with its statues of Day and Night (Fig. 62). There were to have been four monuments for the New Sacristy-built by Michael Angelo for Giulio de' Medici (afterward Pope Clement VII) in 1520 to I 524 , for the Medici family-but it was ten years before the monuments were begun, and then only two were finished. With his usual rapidity when he was once started at work, Michael Angelo in one year finished the "Night" and "Twilight" and had "Dawn" and "Day" well blocked out. Just what these figures mean, who can fathom? but we do know that the master sculptor's heart was full of anguish at this time over the awful tragedy of Savonarola and the terrible conflict that was rending his beloved Florence.

The unfinished figure of "Day" is so suggestive of the mysterious powers of good and evil bound 


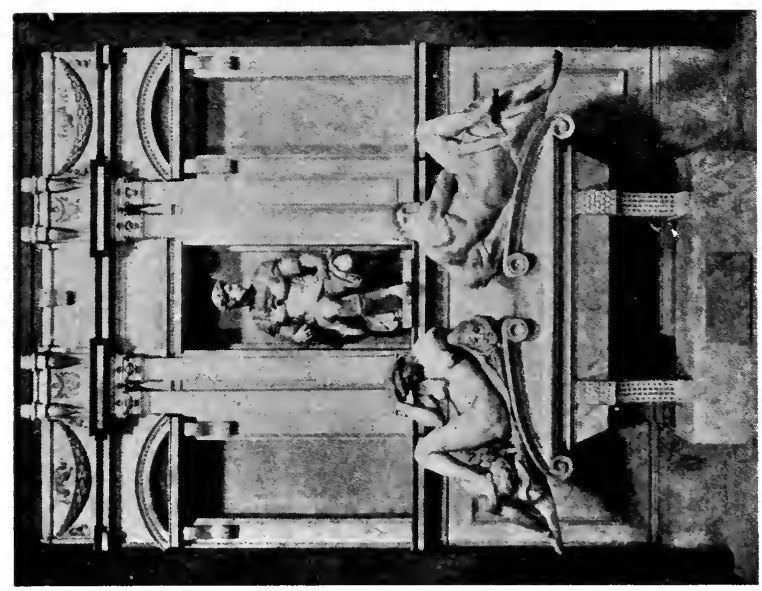

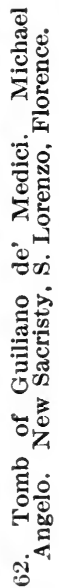

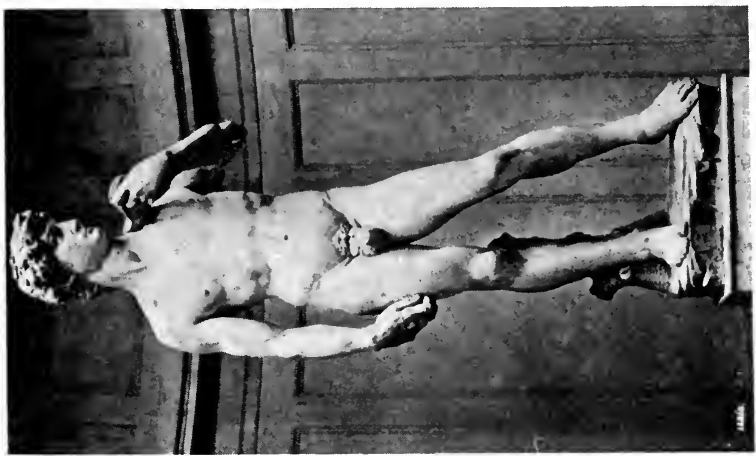

ชี่



$\dot{0}$ 


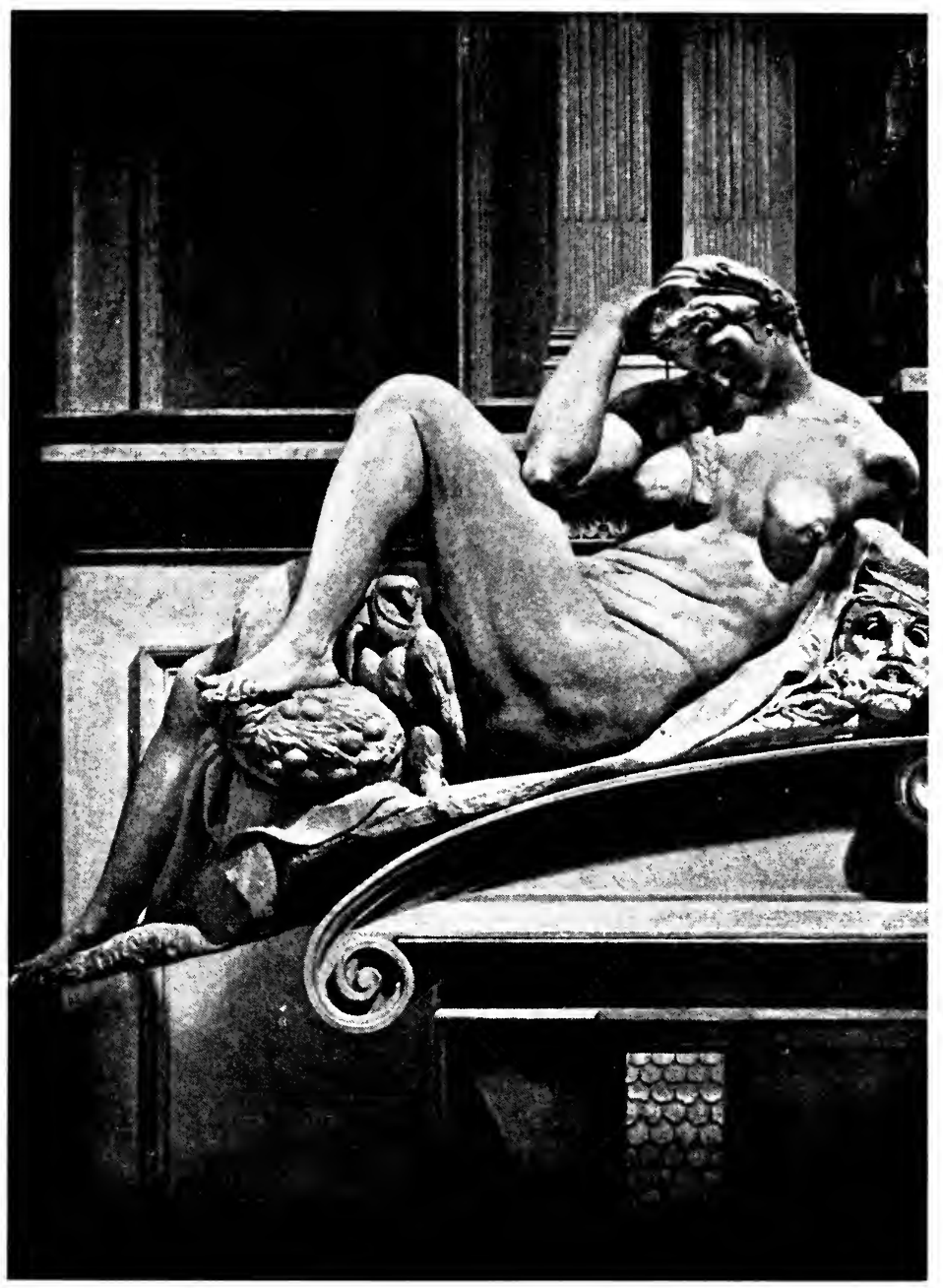

63. Night (detail). Michael Angelo. New Sacristy, S. Lorenzo, Florence. 


\section{FLORENCE}

up in the human soul that we wonder if the artist was not symbolising the secret political intrigues of all time. The veiled figure could well illustrate the old proverb, "For thou knowest not what a day may bring forth."

"Night" (Fig. 63) seems caught by some unseen power in a slumber so profound that the strained, though not unnatural position gives no feeling of discomfort. No, she is not beautiful, but she holds us by some magic spell. Note how carefully worked out is every detail of the accessories-the mask, the owl, the poppy capsule-and how they intensify the conception of night. The lines on the base of the monument, written by Giovanni Battista Strozzi, a contemporary poet, testify to the appreciation of the profound sleeper:

"The Night which thou beholdest, bound in deep And sweet repose, an angel's hand did hew Out of this rock, and, though she is asleep, Breathes: doubt'st thou? Wake her, she will speak."

Michael Angelo, having in mind the political thraldom Florence was passing through, made the statue reply:-

"'Tis well to slumber, best to be of stone, While shame endures and Florence is not free; So lest I waken, ah! subdue thy tone:

Methinks 'tis blessed not to hear or see."

The statue of "Lorenzo de' Medici" (Fig. 64), 


\section{WHAT SCULPTURE TO SEE}

above "Twilight" and "Dawn," is another conception of "Meditation," a companion piece, in a way, to the "Jeremiah" of the Sistine Chapel, Rome. The statue was not intended as a portrait of the Duke of Urbino (Lorenzo de' Medici) but represents the reflective element that keeps the human soul in touch with the undertones binding together human events. This is in direct contrast to the ideal statue of Giuliano de' Medici (Fig. 62), who is represented full of nervous activity, confident that action will conquer the world.

To know the detailed history of the construction of the Medici Mausoleum in Florence and the making of its monuments, would make clear many incidents in the troubled life of Michael Angelo and also give a fair understanding of the factions that were tearing Italy to pieces.

In the Bargello (National Museum) are several of Michael Angelo's works. Here rests his unfinished "Victory," intended for the tomb of Julius II; here also his admirable, though unfinished, bust of Brutus, a late work; and that strange composition, for him, his "Drunken Bacchus" (Fig. 65), made for Jacopo Galli in 1497, when he was twenty-two. It is hard to reconcile this bacchanalian figure in its abandon and ignoble attitude with the "Pietà," in St. Peter's (Fig. 45), made at almost the same time. Only as we believe that one mirrored the degradation of the people under the

$$
\text { [ } 98 \text { ] }
$$



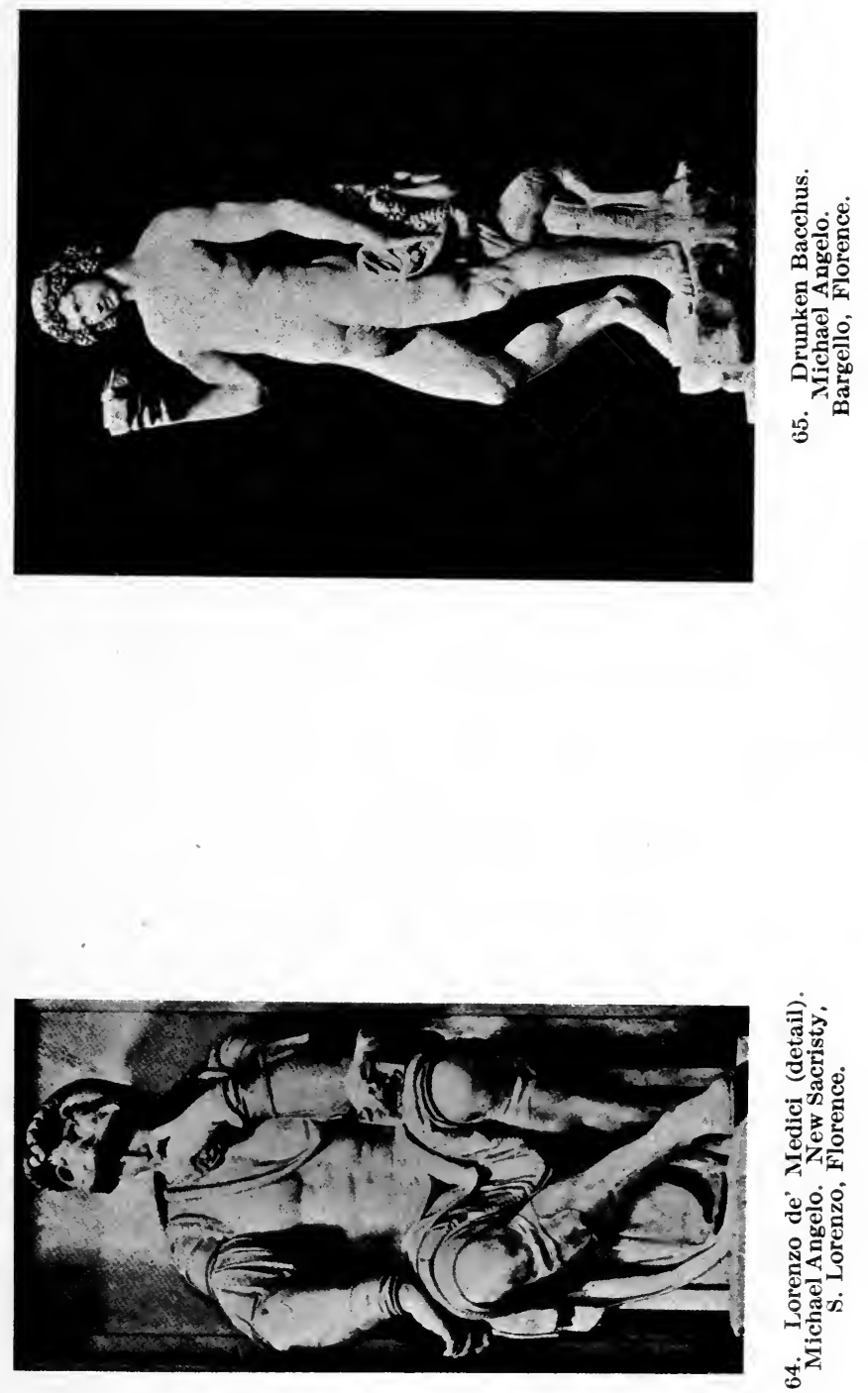



\section{FLORENCE}

reign of the profligate Pope Alexander VI (Rodrigo Borgia), and the other the sculptor's religious convictions awakened by the preaching of Savonarola is it possible to understand these two masterpieces.

This "Bacchus" bears no resemblance to that marvellous "Dionysos," from Herculaneum (Fig. 5). Then the god of wine was looked upon as the promoter of the art of husbandry; but now, two thousand years later, Michael Angelo knew that the god of wine had become the promoter of debauchery. Never for one moment, however, has the young sculptor dropped below the matchless standard of perfect anatomic modelling. 


\section{CHAPTER $\mathrm{X}$}

\section{FLORENCE-BARGELLO}

W ANY of Donatello's single pieces are in the IV Bargello. His "St. George" (Fig. 66), in marble, is full of the courage of conviction-the courage that was the chief characteristic of the saint, as told of him in history and legend. Vasari says of this statue, "The figure of St. George is armed and full of life. The beauty of youth is in the face, resolution and courage in the weapons; a terrible vivacity and living action permeates the marble." Recalling the story of St. George, one feels how truly Donatello has represented the spiritual courage that filled early Christians, where martyrdom was constantly staring them in the face.

The facts about St. George are very meagre. His parents were noble people and Christians; George was a tribune in the army under Diocletian, and was martyred when the emperor discovered his allegiance to the Cross of Christ; his home was probably in Cappadocia. Now legend weaves a wonderful story, always the same. When St. George was on his way to join his legion, he came to a city that was in great distress because of a monster dragon that lived in a marsh near by. The

$$
\text { [ } 100 \text { ] }
$$



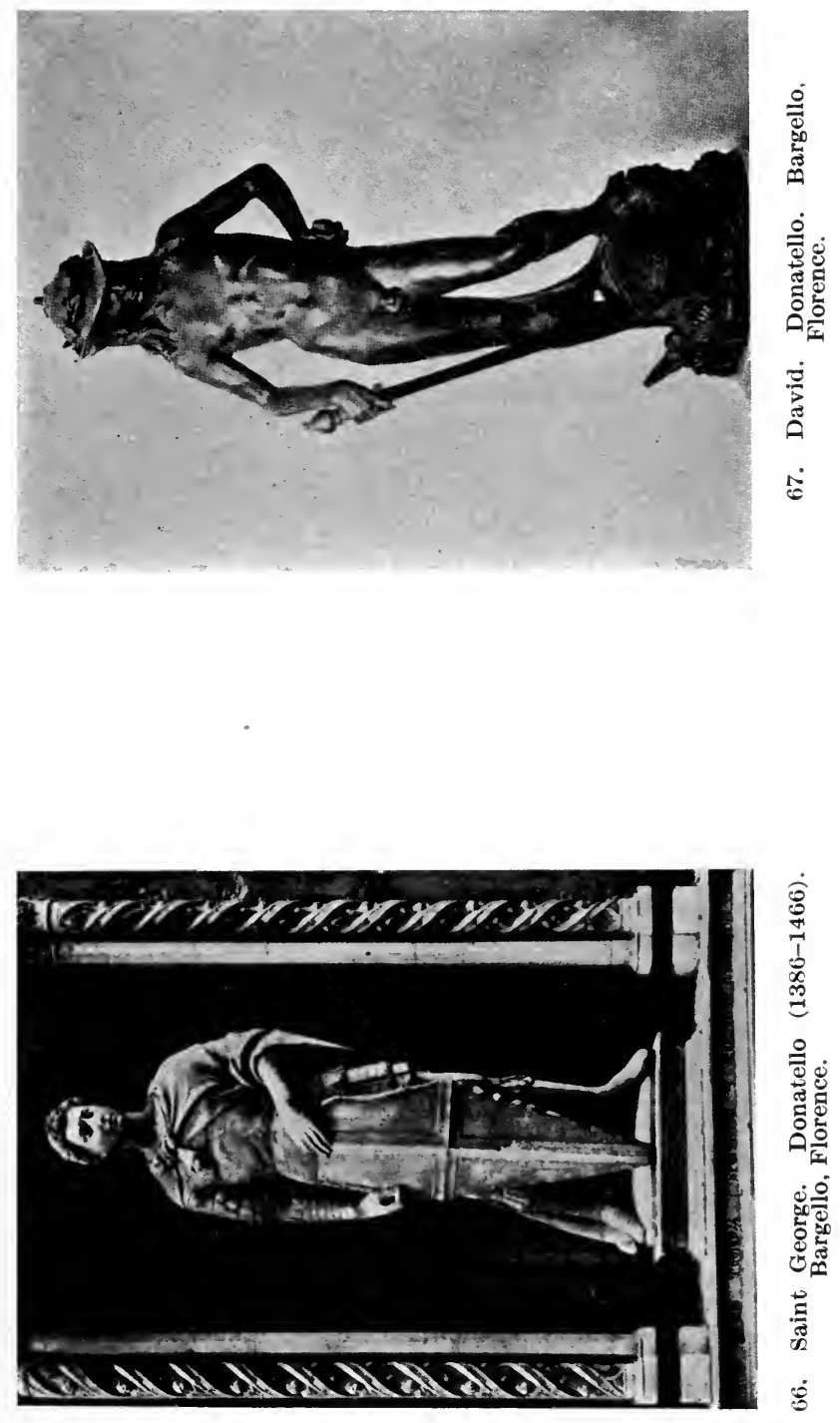


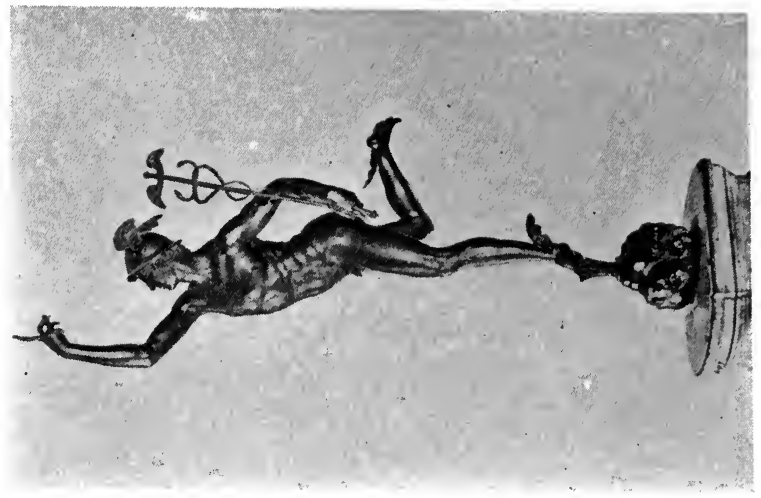

ำ

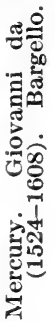

8

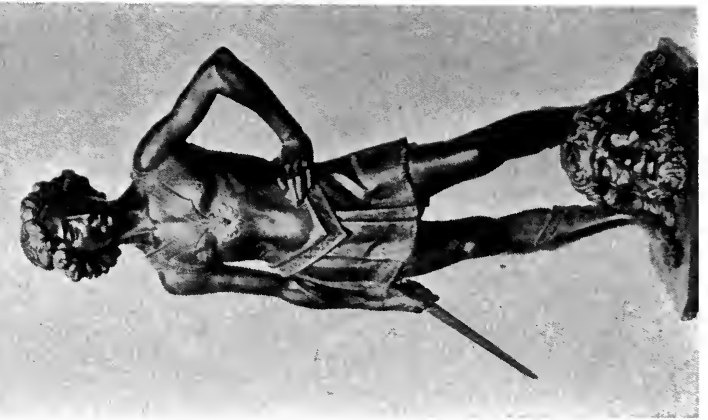

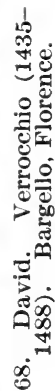




\section{FLORENCE}

dragon had destroyed so many of the domestic animals that the people shut themselves, with their flocks and herds, within the walls of the city; but to keep the monster at bay they fed him two sheep every day. When the animals were all gone they had to throw out two children, chosen by lot and under ten years old. This was the only way to keep the dragon from entering the city and destroying every one.

But the day when Cleodolinda, the king's daughter, was to sacrifice herself to the dragon, St. George appeared before the gates of the city. She was just fleeing outside the walls as he rode up, and when he saw her look of terror and the tears streaming down her face, he asked what was the matter. She told him her story, but implored him to flee for his life. He replied, "God forbid that I should fly! I will lift my hand against this loathly thing, and deliver thee through the power of Jesus Christ."

On the base of the Gothic niche where this statue of St. George stands, Donatello has pictured in bas-relief the saint in a fierce struggle with the dragon, and Cleodolinda is witnessing the scene. She is dressed in the princely elegance of the antique and the whole scene exemplifies the master's great power as a sculptor-even Michael Angelo, the greater artist, could not surpass Donatello on his own ground, sculpture. The result of St.

$$
\text { [ IOI ] }
$$




\section{WHAT :SCULPTURE TO SEE}

George's triumph over the Dragon, so legend says, was that twenty thousand people of the city were baptised into the faith that day. The remainder of the saint's life was full of miracles and conversions, but he was finally beheaded and very early became the Great Martyr among the Greeks. Not until the Crusades was he taken up in Europe, and then he became the patron saint of the army of England and to his honour the Order of the Garter was instituted in 1330 .

The fight between St. George and the Dragon has been the theme of very many Christian artists. His story is much like that of the Greek gods, Apollo, Perseus, Bellerophon, etc., and his destruction of the heathen temple (one of his achievements) with its assembled multitude is a repetition of Samson's overthrow of the Philistines as he made sport for them.

That Donatello was just as true in character delineation in bronze figures, his "David" (Fig. 67) is ample proof. This was one of his first single statues in which he has entirely broken away from an architectural setting where the individual figure is subordinate to the whole. The easy-posed youth reminds one of Praxiteles' gods, though he is none the less a human hero. This "David" was made when the artist was about twenty-one ( 1405 or I 406), ten years before his St. George. The charm of this bronze boy is his youthful enthusiasm 


\section{FLORENCE}

over a deed accomplished. The half smile of satisfaction as he glances down at the boastful dead giant is so boy-like in its genuineness. The strong self-dependence of St. George's personality is lacking, but David's boyish independence wins our hearts.

Another "David" (Fig. 68), in the Bargello, whose individuality attracts us, is that by Verrocchio. Here he lacks some of the boyish unconsciousness of Donatello's "David," yet there is a pride of bearing and youthful self-confidence that marks him as a boy hero. This bronze statue, made when Michael Angelo was a year old (1476), has much of the nobility of bearing that is the marked characteristic of the more celebrated "David," of the Academy. Here "David" holds himself as one who has proved that he is no vain boaster, while Michael Angelo's "David" has the mien of one who feels that the deed accomplished is but the forerunner of greater deeds.

In the next room is a "Bust of Michael Angelo," by Daniele da Volterra. The profile of this bust shows the master's broken nose-a dastardly deed done by the arrogant Piero Torrigiani and boasted of later. Benvenuto Cellini, in his memoirs, gives Torrigiani's version of the affair: "This Buonarroti (Michael Angelo) and I used, when we were boys, to go into the Church of the Carmen, to learn drawing from the chapel of Masaccio. It 


\section{WHAT SCULPTURE TO SEE}

was Buonarroti's habit to banter all who were drawing there; and one day, among others, when he was annoying me, I got more angry than usual, and clenching my fist, gave him such a blow on the nose, that I felt bone and cartilage go down like biscuit beneath my knuckles; and this mark of mine he will carry with him to the grave." At the time Torrigiani told this to Cellini he was seeking young artists to go with him to England to work on the tomb of Henry VII, in Westminster Abbey, but Cellini was so angry because he boasted of breaking Michael Angelo's nose that he refused to go, though the offer promised money and renown.

Near the bust is the well-known "Mercury" (Fig. 69), by Giovanni da Bologna. There is not an ounce of superfluous flesh on the slender, wellpoised figure. Every muscle and tendon quivers with motion, while the spread wings on feet and cap mark his swift flight. $\mathrm{He}$ is equally at home speeding over the ground or sailing through the air. What a pity that Bologna could not have seen that his wind-god base was unnecessary, for he has embodied the very essence of motion in this messenger of the gods.

When the second set of gates were made for the Baptistery, Florence, Brunelleschi and Ghiberti entered into the contest with competitive panels. These panels, "The Sacrifice of Abraham," by

$$
\text { [ } \mathrm{IO4} \text { ] }
$$




\section{FLORENCE}

Brunelleschi (Fig. 70), and "The Sacrifice of Abraham," by Ghiberti (Fig. 7I), now in the Bargello, mark the beginnings of Renaissance Sculpture, and even in these a decided advance is made by Ghiberti, the younger man. The exaggerated action, even to brutality, of Brunelleschi in Abraham's preparation for the sacrifice is offset by the calmer movements of the patriarch in Ghiberti's panel. In the first the angel is forced to grasp the arm of Abraham to stay the descending knife, but in Ghiberti's, who follows more closely the old Hebrew story, "The angel of the Lord called unto him out of heaven, and said, Abraham, Abraham; and he said, Here am I. And he said, Lay not thine hand upon the lad: . . . and Abraham lifted up his eyes and looked, and behold behind him a ram caught in the thicket by his horns."

The final decision as to the merit of the two panels was really made by Brunelleschi himself for, when he saw Ghiberti's panel, he withdrew from the contest, avowing that his work was not equal to that of Ghiberti's. Vasari reports the verdict at that time "that the rival plate of Brunelleschi, being made in several pieces of bronze, proves his ignorance of the art of casting." Ghiberti's is cast in a single piece of metal.

We learn from Ghiberti's own words how carefully he studied nature and what pains he took 


\section{WHAT SCULPTURE TO SEE}

to reproduce what he saw. He says:- "I sought to understand how forms strike upon the eye, and how the theoretic part of graphic and pictorial art should be managed, working with utmost diligence and care, I introduced into some of my compositions as many as a hundred figures, which I modelled upon different planes, so those nearest the eye might appear larger and those more remote smaller in proportion." Even in this single panel one feels Ghiberti's sense of proportion and keen appreciation of nature; the foreground, the middle distance, and the background are as accurately preserved as though painted on canvas. The two scenes-the waiting men with the donkey and Abraham stayed by the angel-are in perfect accord with each other. Then, too, his sense of the beauty of face and form is shown in the boy Isaac; the innocent way he throws back his head as though still wondering what his father means by acting so strangely. But to understand the significance of the rules laid down by Ghiberti for the working in metal, one must examine the Baptistery Gates. 

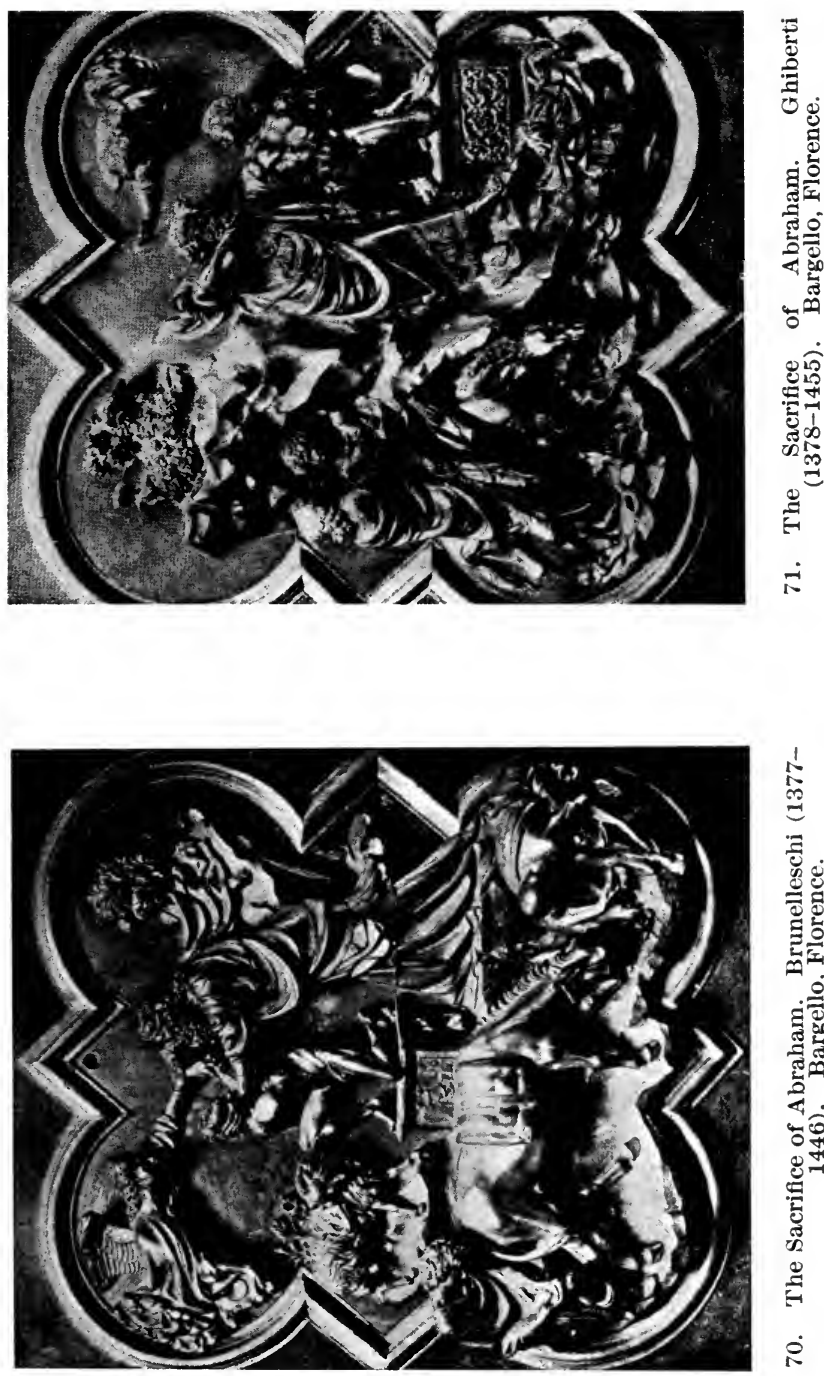

年 


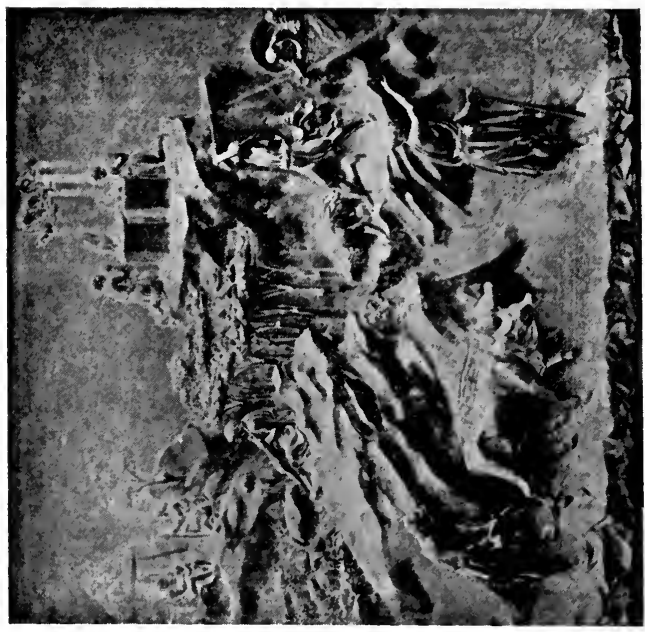

宅 0

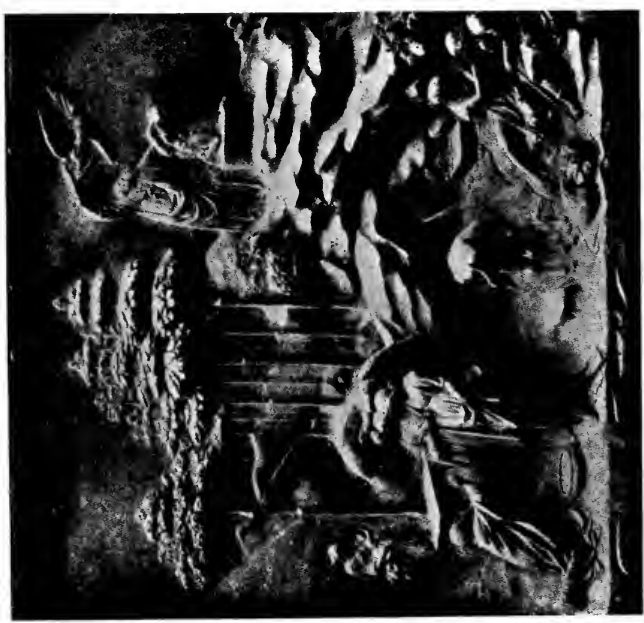

चैं 


\section{CHAPTER XI \\ FLORENCE-MISCELLANEOUS}

70 really appreciate Ghiberti's work one must 1 remember that he and his brother artists, Brunelleschi and Donatello, had inaugurated an independent movement in religious art and that now the treatment of Bible subjects was no longer under the control of the church. These artists stood ready to fill commissions for religious subjects, but they had the temerity to insist on using their own individuality as to how the work should be done, and consequently a new era of art dawned in Italy and the Renaissance became an established fact.

In November, I 403, Ghiberti received the commission for his first Baptistery gates and, in the year 1424, after twenty years of work, they were hung in place on the north side to guard the principal entrance of the Baptistery. Twenty of the subjects depicted are taken from the life of Christ, and the remaining eight are scenes from the lives of the church fathers. That same year, I424, Ghiberti began work on the second set ordered by the Signoria. Again twenty years elapsed before his task was completed and the gates were ready. In the scenes on the second gates Ghiberti adopted 


\section{WHAT SCULPTURE TO SEE}

Brunelleschi's new system of perspective in painting and, with his brush of steel, perfected pictures in bronze that in the hands of a lesser man would have been failures. Like Michael Angelo a hundred years later, Ghiberti dared and succeeded where his followers dared and failed. It is little wonder then that Michael Angelo exclaimed upon first seeing the gates, "They are fit to be the gates of Paradise."

The scenes for the second gates are from the Old Testament. Each scene of the twenty-eight sections is a perfect little genre picture in bronze. In the fourth panel Ghiberti has incorporated the sacrifice of Isaac, the subject of his competitive panel, with two earlier incidents in the life of Abrahamthe appearance of the three angels and Hagar and Ishmael in the desert (Fig. 72). These stories are a little harder to manage pictorially and keep chronological, but Ghiberti was equal to the work. Notice how completely he has subordinated the two scenes in the foreground to the sacrifice, the culminating incident in the development of Abraham's faith. The tall trees bordering the hillside act as screens to minimize the angel's visit while they intensify the sacrifice on the hilltop farther away. Naturally our eye follows upward the trend of the rocks and the stately tree tops until it rests upon the point of intensest action.

Now compare the artist's treatment of the sacri[ 108 ] 


\section{FLORENCE}

ficial scene with "The Story of Cain and Abel" in the second panel (Fig. 73), and notice how naturally our eye seeks out the main tragedy and then moves on to the more restful scene of commonplace work. This panel, "Cain and Abel," is one of the most vivid in its realism, yet one of the most ideal in its conception. Ghiberti thoroughly understood nature's great out-of-doors. In tracing the story of these first brothers from early boyhood, through the sacrifice, the murder and tilling the ground, each scene is presented in detail, yet with successive steps in perspective until the men and oxen in the foreground in high relief fairly startle us with the warmth of their presence. Real ploughing could be done with that yoke of oxen, for they have the strength of the soil. See how realistically the nigh ox tosses his head in response to the spoken command! Could anything be more exquisitely natural than the shepherd dog watching the flock of sheep on the left? In the decorated border around the panels are prophets and sibyls and portraits; among the latter, the conspicuous baldheaded man is the artist himself.

An interesting glimpse of Florence at the time Ghiberti made his gates is given in a public notice dated January 7, 1407; it reads:- "All working at the doors of San Giovanni-Baptistery-(are licensed) to go about Florence at all hours of the night, but always carrying lamps lighted and visi-

[ IO9 ] 


\section{WHAT SCULPTURE TO SEE}

ble." What familiar figures Ghiberti and his workmen must have been along the dark streets the half century those marvellous gates were in process of making! and how often a poor belated wanderer must have blessed the tiny light that came from the friendly lamps.

When Ghiberti had finished his second set of gates, it was a serious question where to put them. The most conspicuous place was opposite the cathedral where Andrea Pisano's gates for a hundred years had guarded the entrance to the Baptistery. But it was decreed by the authorities that the older gates must give place to the new masterpiece and today Ghiberti's second set of gates face the cathedral, while Pisano's gates are on the south side, where we will now examine them more closely.

The scenes represented are from the life of John the Baptist and allegorical figures of various virtues. We are struck at once with the few figures Andrea uses in telling his stories. Their simplicity is charming. Look at "Zacharias Naming the Little St. John") (Fig. 74). The artist, in his crisp concise manner, has told the story in true gospel spirit: "And he asked for a writing tablet, and wrote, saying, His name is John. And they marvelled all. And his mouth was opened immediately, and his tongue loosed, and he spake, and praised God." St. Luke i. 63, 64. In the halo around the head of the woman holding the 


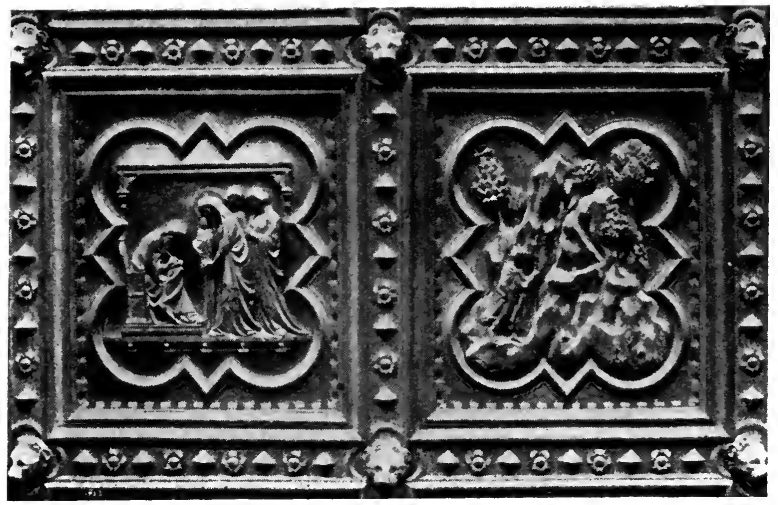

74. Zacharias Naming the Little St. John. Andrea Pisano (12701345). South Doors, Baptistry, Florence.

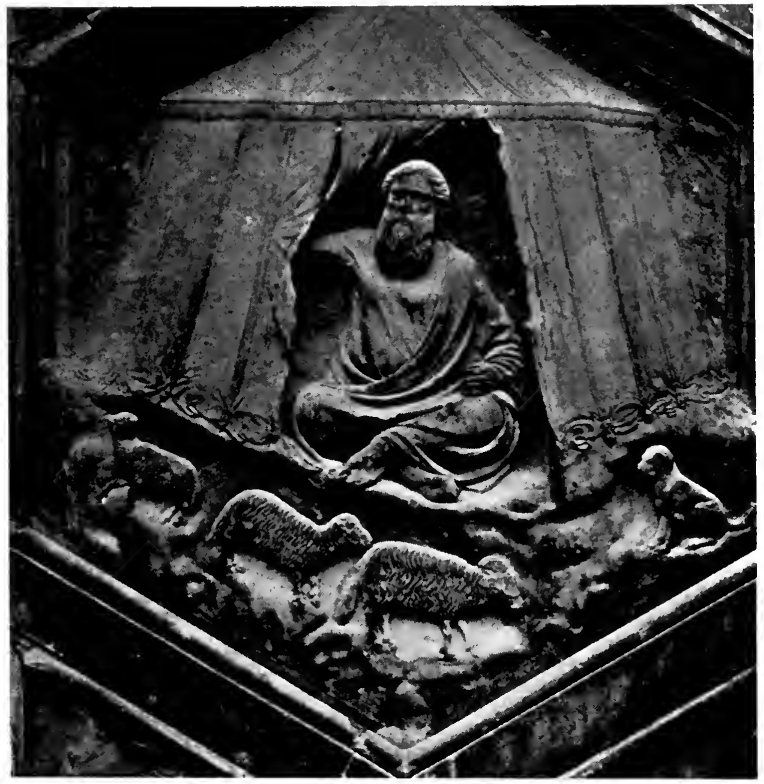

75. Jubal at Tent Door. Giotto, Campanile, Florence. 


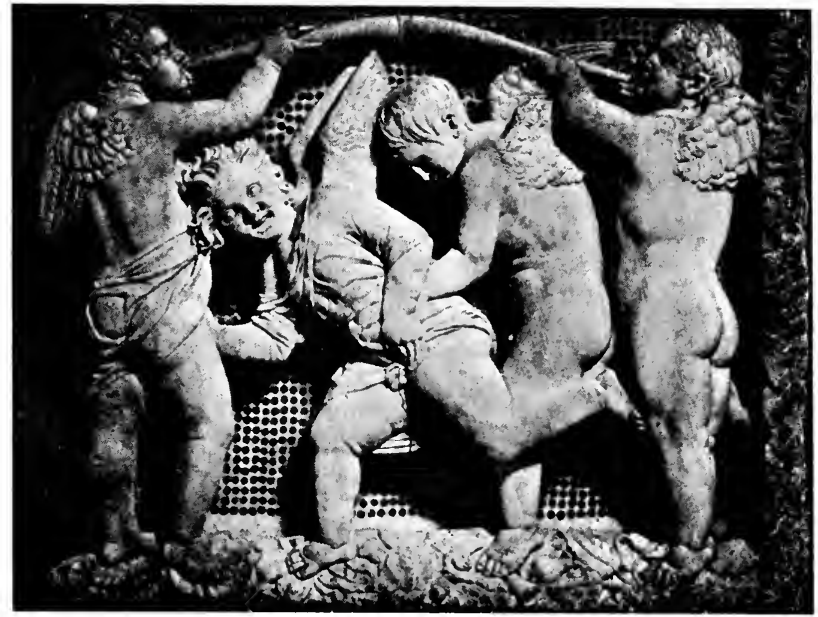

76. Singing Boys (Iower Panel). Donatello. Cathedral Museum, Florence.

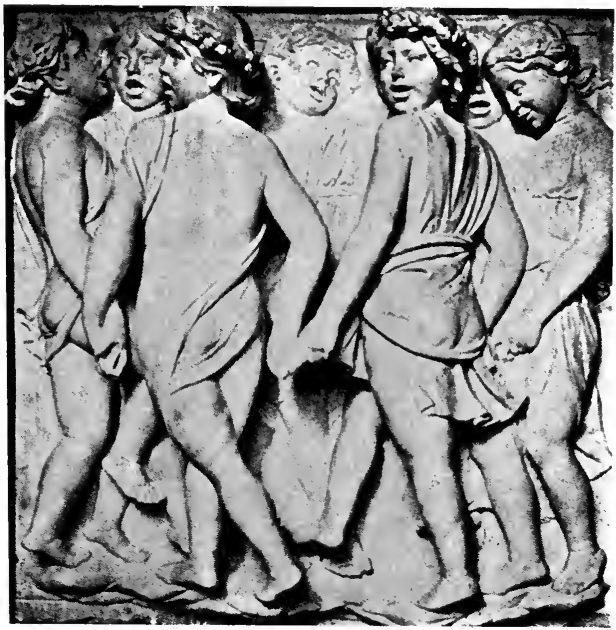

77. Singing Boys (Lower Panel). Luca della Robbia (1399-1482). Cathedral Museum, Florence. 


\section{FLORENCE}

baby, Andrea has preserved that very old tradition that Mary stayed with her cousin Elizabeth until after the birth of little John. This tradition was recognised by the early northern masters, as seen in Van der Weyden's painting of the "Naming of St. John," in the Berlin gallery.

When the gates were put in place opposite the cathedral ( $133^{6}$ ), Pisano was granted the freedom of the city of Florence. This was a great honour, for it raised the artist from being simply the beautifier of a building to the place of public benefactor-and rightly so, for one who educates the finer qualities of the public mind is truly a benefactor.

Andrea Pisano and Giotto were close friends while the latter was building his famous Campanile. They worked together, these two men and Luca della Robbia and Donatello, on this "Lily of Florence." Giotto designed and the others executed most of the work. It is scarcely possible to designate just which reliefs were done by Giotto's own hand, though Ruskin in his "Shepherd's Tower," believes that "Pastoral Life" (Fig. 75), the centerpiece of the west side, was made wholly by him. The man in the tent door is Jubal, the father of such as dwell in tents. You will be enthusiastic over the little dog; he is so like all puppies in his pert assumption of dignity. To watch those wooden sheep is a great accomplishment to him.

$$
\text { [ I I I ] }
$$




\section{WHAT SCULPTURE TO SEE}

Giotto may have been drawing just such a little dog, his own companion, on the flat rock when Cimabue found him tending his sheep. We feel in all these reliefs that Giotto is putting into the scenes figures that have come under his own observation.

We will now go into the Singing Gallery of the Cathedral Museum and see Donatello and Luca della Robbia's "Singing Boys." Possibly no marble children in relief are better known the world over than these rollicksome songsters. Music and dance are as much a part of their being as the murmur and sparkle are a part of the hillside brooklet as it glides over its stony bed. These creatures of mirth live and breathe music and dance. Possibly Donatello has given a little more of the spirit of the woodland faun in the wilder antics of his sprites (Fig. 76), but Della Robbia's "Singing Boys" (Fig. 77) lack nothing in exuberance and ease of motion. We bless the little musicmakers with all our heart! In comparing the two groups, one must remember that Donatello intended his panels for an organ balustrade where height would counteract any apparent inequality in perspective that shows near at hand.

There was never a sweeter company of babies than Andrea della Robbia's jolly, roly-poly band stretching across the front of the Foundling Hospital, Florence (Fig. 78). He has placed each

$$
\text { [ I I } 12 \text { ] }
$$




\section{FLORENCE}

wee mite in his own circle of blue and white and has made each little tot as individual as the darling in our own home. Such a welcome to the home of the homeless babies has made Andrea della Robbia's bambinos justly famous. For five hundred years these majolica medallions have stood as the emblem of the successful care of homeless little ones.

Until very recently the babies of the Foundling Hospital were brought up on goats' milk. The goats were kept near at hand and when a baby cried for its milk the particular goat acting as its foster-mother would trot off to the wee one and nurse it as though it were its own little kid. The custom has been abolished and the bottle system put in its place. Evidently nature and science conflicted and science won out-what a pity!

A most delightful half day can be spent in Florence with a carriage and intelligent driver searching for the out-of-the-way works of the Della Robbias. Glorious altar-pieces gleam out in filthy alleyways, exquisite madonnas smile down from over dark doorways, beautiful medallions in crumbling walls come forth clean and pure from their dust coverings of ages. One is sure to find treasures unharmed by contact with the crime and filth of the "other half."

A particularly fascinating bit of genre in bronze is the "Boy with a Dolphin" (Fig. 79), by Ver-

[ I I 3 ] 


\section{WHAT SCULPTURE TO SEE}

rocchio in the court of the Palazzo Vecchio. It is all the more interesting because it was unusual for the artist to portray frolicsome boyhood. He certainly has caught the very essence of fun in this runaway, with his slippery fish. One would not be surprised to see him dance off his standard and fly away with his burden regardless of his duty as water-carrier in the court fountain. We shall hear of Verrocchio again in Venice and learn to love him too as did his pupil, Lorenzo di Credi, when he painted his portrait for the pure love of his master. 

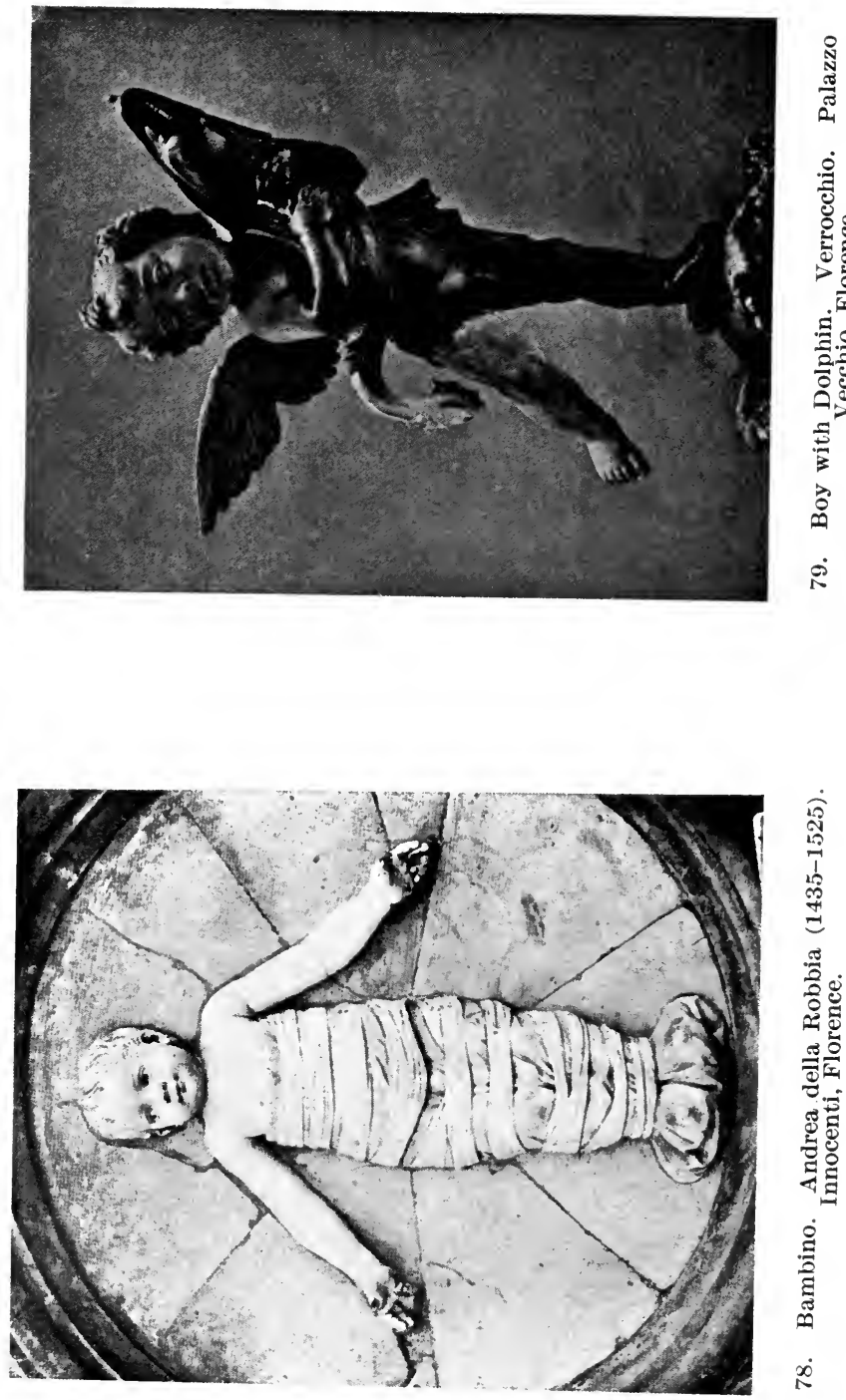


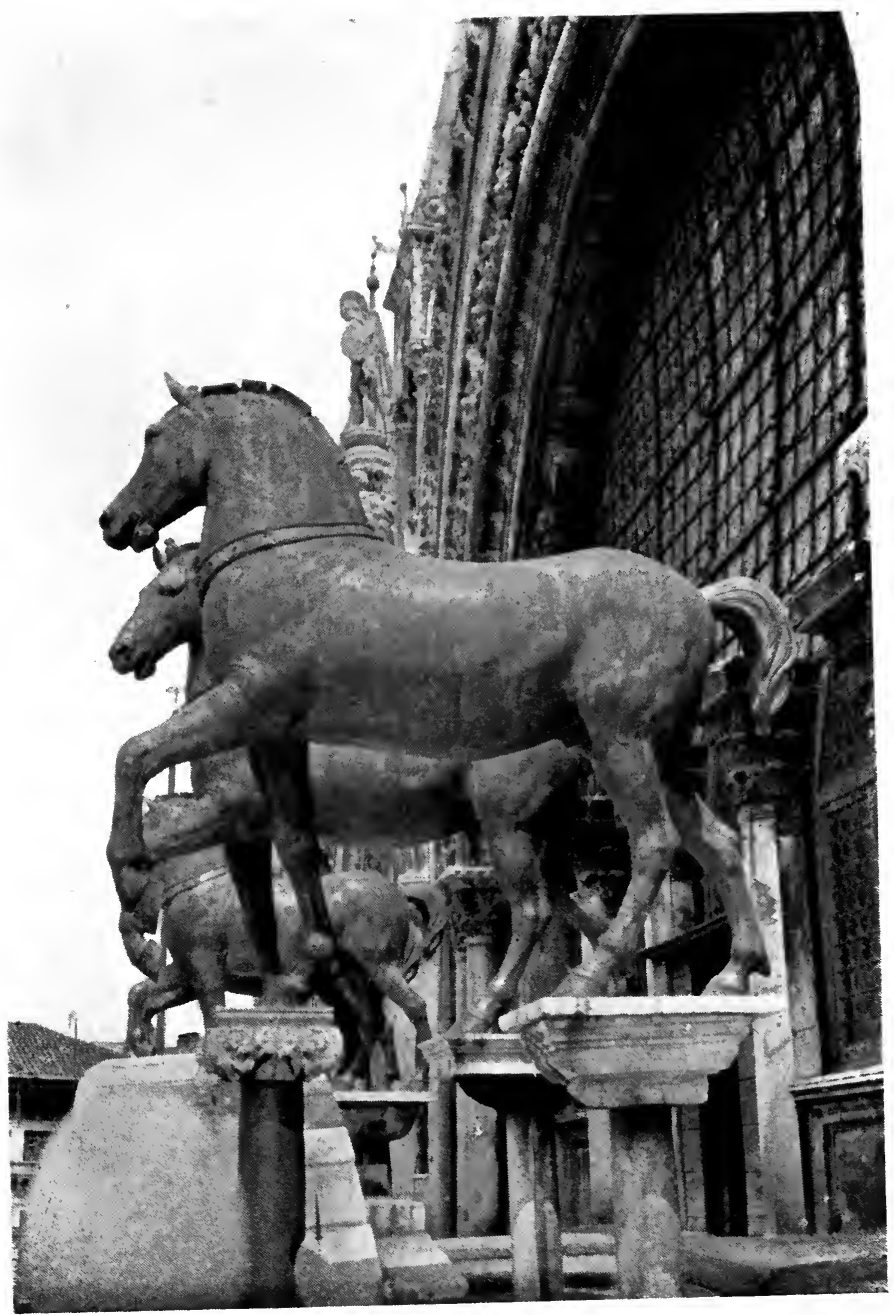

80. Bronze Horses. st. Mark's Cathedral, Venice. 


\section{CHAPTER XII}

\section{VENICE}

" THE BRONZE HORSES" above the main portal of San Marco, Venice (Fig. 80), are among the finest pieces of ancient bronze work in existence, and also are the one remaining example of the ancient quadriga. It is possible they are Greek works of the school of Lysippus, the fourth century B. C. They are made of Corinthian brass and probably fronted a temple in Corinth. They were brought to Rome by Minnius in $146 \mathrm{~B}$. C., when he had completed the Roman conquest of Greece, and were placed in the square of the senate. In the first century A. D. they adorned the arch of Nero in Rome and afterward that of Trajan. When Constantine changed the name of old Byzantium to his name-sake city of Constantinople (A. D. 330), he took the bronze horses to crown the Hippodrome of Constantinople, the new Rome.

For nearly a thousand years the Golden Horn was well guarded by the Bronze Horses, but then came Doge Enrico Dandolo from Venice, I204, and Constantinople was conquered. The horses

$$
\text { [ I I } 5 \text { ] }
$$




\section{WHAT SCULPTURE TO SEE}

were carried off to Venice and set up above the main portal of the Cathedral of San Marco. The "travelled horses" were now at rest for nearly four hundred years, then Napoleon passed through Italy-"Veni, vidi, vici"-and the horses were taken to Paris and placed on the triumphal arch of the Place du Carroussel. This position of triumph was no more lasting than that of the great Napoleon himself. In I815, when European peace was established, Emperor Francis I. of Austria claimed them, and when Venetia was assigned to him, returned the horses to their present position above the portal of San Marco.

Let us hope they will remain in their present position, for no place in Christendom better suits them. Here they enjoy the free air of heaven, as though still in their native desert, and here they look down upon one of the most charming scenes that was ever granted horses or men to see. Not only man's finest handiwork is spread out before them, but one of Nature's beautiful creations, a flock of pigeons, circles around them day after day. Special honour is due these bronze horses in Venice, for in this queen city of the Adriatic a live horse is unknown.

As we wander through the narrow streets of Venice-if the flagstone-paved alleys can be called streets-we come rather unexpectedly upon a little piazza facing the church of SS. Giovanni e Paolo,

$$
\text { [ I I } 6 \text { ] }
$$




\section{VENICE}

and find before us Verrocchio's marvellous "Equestrian Statue of Colleoni and his Horse" (Fig. 8I ). Ruskin writes:- "I do not believe there is a more glorious work of sculpture existing in the world than the equestrian statue of Bartolomeo Colleoni." This is extravagant praise, yet, regardless of correct equine anatomy, Verrocchio has breathed a martial spirit into the horse that has made him a fit companion to a great general.

Colleoni, one of the great generals of the fifteenth century, left at his death, in 1475 , the larger part of his great wealth to the Republic of Venice, with the request that a bronze equestrian statue should be made of himself and set up in the Piazza of San Marco. The Signoria was gracious enough to carry out the first part of the request but found a loophole in a law against placing a statue in the great Piazza San Marco and satisfied their conscience and secured the fortune by placing it in the piazza of the Scuola of San Marco.

Three artists were appointed to make models for the statue and Verrocchio's was chosen as the finest. As he was a Florentine, certain Venetians, jealous of his fame, plotted against him until the authorities were persuaded to withdraw part of the order and only allow him to provide the horse, while one of his rivals should execute the great Colleoni. Verrocchio was so enraged when he heard this that he broke up his model and returned 


\section{WHAT SCULPTURE TO SEE}

to Florence. When the Signoria heard he had gone they sent word to the sculptor that if he ever dared to set foot in Venice again he would lose his head. To which message the intrepid Verrocchio replied that if they cut off his head it was not in their power to put it on again, but that he could replace the head on the broken model of the horse and-wily man that he was-added, "I could make it even more beautiful than it was before." Needless to say, the sculptor was ordered to return to Venice and finally the completed statue was uncovered to the public March 2 Ist, 1496. Verrocchio lived to complete only the model, and at his death disputes and false claims almost deprived him of his rights, but to-day Verrocchio receives all the glory.

When the Campanile of Venice collapsed, July I 4th, 1902, the Loggetta and its treasures were buried under the débris. Fortunately the small bronze statues of Peace, Mercury, Apollo, and Pallas were very little injured, and the broken material of the waiting-room could be pieced together; so to-day Jacopo Sansovino's masterpiece again adorns the base of the Campanile.

Sansovino added the Loggetta and its dainty bronzes to the Campanile in I 540, and immediately this waiting-room became the favourite meetingplace of the Nobili, and here they discussed various questions-probably the artist's work. among 


\section{VENICE}

others. Sansovino has left his individual stamp on more buildings in Venice than any other artist. For forty years his success was phenomenal. Only once did the authorities disapprove-he was held responsible for the falling in of the Library roof while it was building - but after paying a heavy fine and four years' imprisonment he was reinstated in public favour.

Sansovino's "Mercury" (Fig. 82), in the Loggetta, is classic in its simplicity, yet, excepting the winged cap, there is nothing to distinguish the god from a wholesome Italian youth of the sixteenth century. It may be that the curly headed footstool typifies the hundred-eyed Argus that Mercury beheaded, and the god's attitude of pensive interest may be due to his witnessing the gradual transformation of the beautiful heifer back again into the lovely illfated Io-but who can tell?

Sansovino's terracotta group of the Madonna and Child and St. John was broken into a thousand pieces, but with the greatest patience the fragments of the Madonna and Child have been pieced together-the little St. John was past redemption - and can now be seen in the Loggetta.

Let us examine for a few moments the bronze bases of the flagstaffs in front of San Marco. These were cast by Alessandro Leopardi, the sculptor who finished the Colleoni equestrian statue. Note specially the medallions on the central base. 


\section{WHAT SCULPTURE TO SEE}

They represent Doge Leonardo Loredano, and are probably taken from Giovanni Bellini's beautiful portrait of him in the National Gallery, London (see page 156 in "What Pictures to See in Europe").

Again and again the "Winged Lion of St. Mark" (Fig. 83) appears in Venice. The figure of special significance is on the east granite column in the Piazzetta facing the lagoon. This granite column is one of three single blocks that were brought from Tyre in I 26 as trophies, after the capture of that city from the Saracens by Doge Domenico Michiel. When they were being unloaded at the Piazzetta one column fell into the sea and probably is there yet, the other two were landed in the square, where they lay for fifty years waiting for some genius bright enough to raise them in place. Finally a Lombard, Niccolo "the blackleg," under promise of receiving whatever he demanded, raised them into position with wetted ropes. He was granted his petition-a gaming table between the columns. But the Doge and counsellors outwitted his scheme by causing all public executions to be made there too. Naturally executions and a gaming table were not congenial, and pleasure gave place to punishment.

The lovely capitals of the columns were doubtless carved in Venice in the twelfth century, and the winged lion of St. Mark is also a piece of

$$
\text { [ } 120 \text { ] }
$$




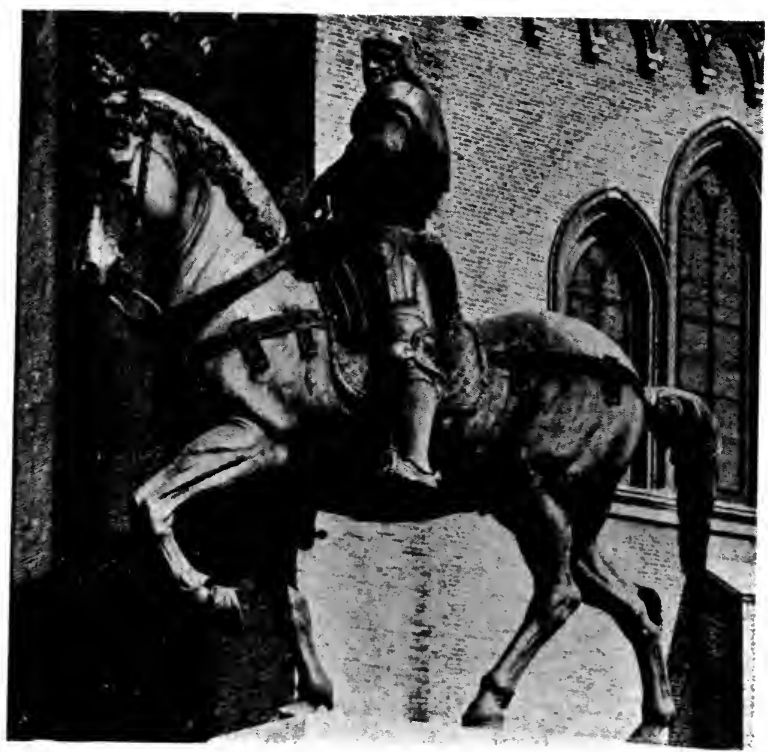

81. Statue of Bartolomeo Colleoni. Verrocchio. Piazzi of San Giovanni e Paolo, Venice.

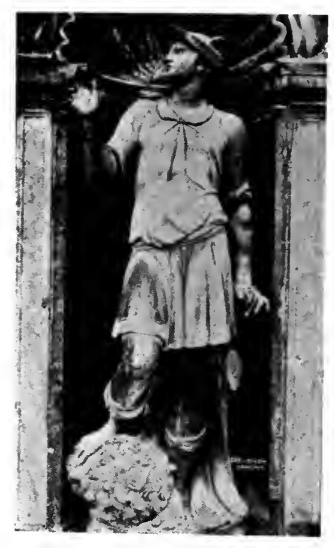

82. Mercury. Jacopo Sansovino $(1487-1570)$. Loggietta,

Campanile, Venice.

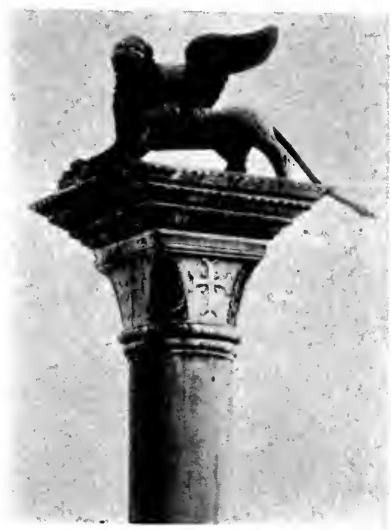

83. Lion of St. Mark. Column in

Piazzetta, Venice. 

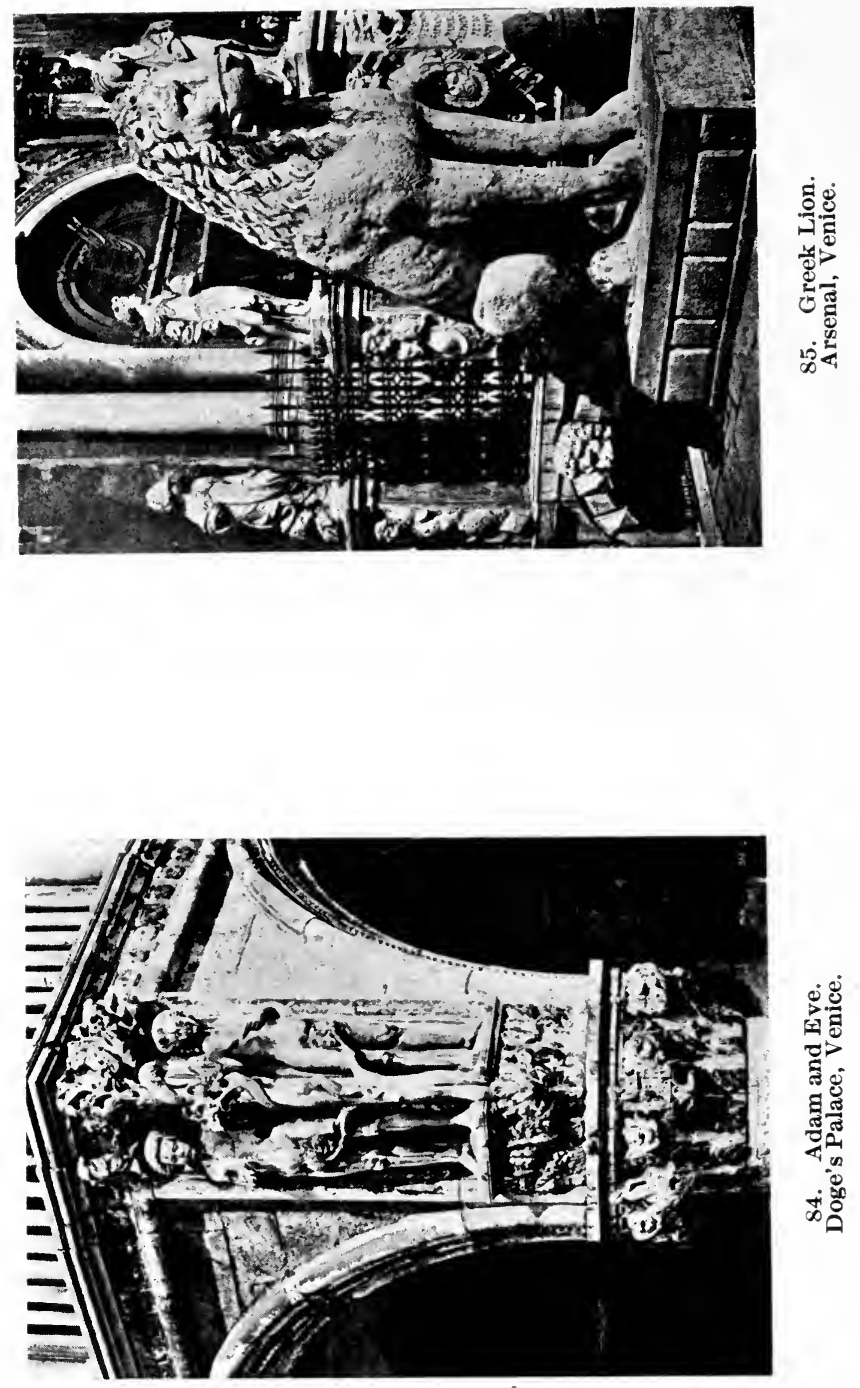


\section{VENICE}

ancient native bronze work, though the wings are comparatively modern.

The Lion of St. Mark is symbolic of St. Mark the Evangelist, the patron saint of Venice. The symbols representing the writers of the Gospels are among the earliest in Christian art. The most common of these represent St. John as an eagle; St. Luke as an ox; St. Matthew as a man; and St. Mark as a lion. These symbols are taken from the account of the four beasts in Revelation, iv. 6 to ro. The lion symbolises St. Mark for three reasons: I, He opens his gospel with "The voice of one crying in the wilderness"; 2, The lion as king of beasts symbolises Christ, the royal son of God; and 3, an Oriental tradition says that young lions are born dead, and after three days the breath and roar of the king of beasts brings them to life. This represents the resurrection, of which St. Mark gives a special history.

The traditions and legends of St. Mark are very closely connected with the history of Venice from A. D. 815, when some Venetian merchants despoiled his tomb at Alexandria in Egypt and took the sacred relics to Venice, where the cathedral of San Marco was built to contain them.

We must not overlook the statues above the baseless columns of the Doge's Palace. The delicately carved foliage and exquisite arrangement of the figures of the capitals give a setting for sculp- 


\section{WHAT SCULPTURE TO SEE}

tures unequalled in all Europe. Notice specially the "Adam and Eve Corner" (Fig. 84), toward the Lagune. How perfectly the nude figures of Adam and Eve fit into the scheme of decoration. The amused expression on their faces gives no hint of the tragedy hanging over them, though the artist has skilfully woven the legend of Lilith, Adam's first wife, into the climbing, twisting vine between them. The serpent, with Lilith's head, is the tempter in the old works of art. Eve will soon feel the influence of the outraged Lilith-and then the apple will do its deadly work. There is really not much of the beauty of the human figure in these statues, yet the naïvete of the sculpture is pleasing.

But let us look at another "Adam and Eve" group inside the court of the Palace. We will mount the Giant's Staircase and turn, facing the archway through which we entered. The nude figures are before us in the niches above. These statues were made by Antonio Rizzo about 1462 . They are truly admirable examples of the nude, and quite superior to most of the architectural figures of the early Renaissance. It is interesting to contrast the modest submission of Eve, in her willingness to acknowledge her sin, with the selfjustifying attitude of Adam. See how confidently he places his hand on his breast, and with eyes raised to heaven, seems to say, "The woman whom thou gavest to be with me, she gave me of the tree, 


\section{VENICE}

and I did eat." Rizzo has put into these figures a rhythm of action between joints and muscles that shows his understanding of the anatomy of the human body, and yet he has preserved the delicate flow of line that gives to marble the quality of warm, healthful skin.

There are four splendid antique "Greek Lions" at the gate of the Arsenal in Venice that we must not fail to see. These lions were brought from Athens in 1687 and 1716 . In their native home they guarded the Piræus harbour-at one time the harbour itself was called Porto Leone-the Sacred Way leading from Athens to Eleusis (the Shrine of Mysteries), and the Attic battlefield of Marathon. The lions are made of Pentelic marble. The large sitting one (Fig. 85) with the Runic inscriptions guarded the harbour, and a splendid watchman he certainly was! 


\section{CHAPTER XIII}

\section{MUNICH}

THE greatest treasures of the Glyptothek Gal1 lery in Munich are the Aiginetan Marbles. They stand to that Museum what the Parthenon Marbles do to the British Museum in London. True, they are not so beautiful as the English treasures, but as a connecting link in the study of sculpture in the islands surrounding Greece they are invaluable.

When the fragments of the Aigina marbles were discovered in I $8 \mathrm{I}$, by some English and German scholars, the French, English and German governments all wanted them. The fragments were taken to the island of Zante, one of the great commercial centres of Greece then as now. After the sale had been announced, a statement was sent out that the marbles had been sent to Malta, where the sale would take place. The German agents were suspicious of this statement and decided that they had better stay in Zante and await results. Their suspicions were correct-the sale was in Zante, and Germany, having the only agents on the ground, bought the precious fragments for thirty thousand dollars. The marred and broken collection was 


\section{MUNICH}

then sent to Rome and put into the hands of the sculptor Thorwaldsen, the idol of the German people, to be restored. Technically his work was good, but misconceived in spirit. The plaster models of the Aigina group, made by Furtwängler, which stand near the marbles, give the more correct idea of what the originals must have been in their pristine perfection.

These figures, in Parian marble, were once on the pediment of the temple of Athena, or possibly a native goddess, in the island of Aigina. They probably represent Trojan and Greek warriors fighting over the dead body of the hero who lies at the feet of the goddess. In the central group on the west pediment (Fig. 86), stands Athena, tall, stiff and unconscious, as though she were simply a connecting link between the sloping groups on either side. To fill the gable of the building with statues and have them artistically correct, a tall central figure or group was necessary. In the restored grouping there are two stooping warriors in the background contending for the fallen warrior, while the two warriors with shield protect them. This arrangement gives more continuity to the composition. It is very evident that the sculptor (it may have been Onatas, 480 B. C.) who made the group is still under archaic influence, and yet in the nude warriors he shows considerable knowledge of anatomy. At least he has made hu-

$$
\text { [ } 125 \text { ] }
$$




\section{WHAT SCULPTURE TO SEE}

man bodies, while in Athena he has hung her clothes from a coat-hanger, with her head and arms simply attached from the outside. But Athena is goddess-like as she towers above her warriors, and her garments have all the insignia of her office, the dread ægis with its Gorgan head in the centre, the Attic helmet with its high crest, the protecting shield and the cruel lance-all these show her completely armed for war.

The fallen hero and the fighting warrior claim our admiration, however, for they have developed bodies fit for fighting. The framework of these bodies is anatomically correct and the muscles are distributed with considerable skill. True, there is not much life in the finished figures, but they point toward greater achievements in this line.

The figures in the east pediment certainly show great advancement over those of the west. Naturally the end of the temple facing the sea would be the first to be decorated, therefore the west pediment has the older marbles and it may have been several years before the east end was completed. Onates may have designed the work for both pediments, and then his son Calliteles finished it. Unquestionably the work on the east end is far superior to that on the other end. Look at the "Fallen Warrior" (Fig. 87), and note how much more of the spirit of life he has than those fighting warriors of the opposite end. The muscles have

$$
\text { [ } 126 \text { ] }
$$




\section{MUNICH}

now been endowed with the power of motion. The lifted leg is capable of straightening itself out again, and the whole body seems able to respond to the will of the man. Notice that the toes are unequal in length, as in life, and that the tendons of the shin and foot have responded to the stretch of the leg and toes that pain often causes. The general arrangement of the figures of the two pediments is the same, but the artist of the east end has dared assert himself and improves on the archaistic principles of the past.

There are two statues in the Glyptothek that belong to the Niobe group in Florence (see page 88). There are four replicas, in Florence, Turin, Dresden, and in Munich the "Dead Niobid" (Fig. 88). Death has claimed this son; the struggle is over. Soon all the sons and daughters of the ill-fated Niobe will be lying still in death. The pathetic story of the destruction of these beautiful sons and daughters never loses its interest because of repetition.

For a long time the beautiful torso of "Ilioneus" (Fig. 89) was thought to be Narcissus, but Thorwaldsen saw in it the last remaining son of Niobe. Although but a fragment, we can see him raising his arms to heaven and hear him crying in tones of anguish, "Spare me, ye gods!" But his cry came too late. Apollo would have saved him, but the fatal arrow was already on its way. Some author- 


\section{WHAT SCULPTURE TO SEE}

ities disagree about this being Niobid, because all the other statues of the group are either draped or have drapery at hand, while this figure is entirely nude.

Medusa's head seems to have had a special charm for Greek artists. They portrayed her in all stages of transformation, from the hideous monster with coarse features, tongue protruding and snaky locks under the curse of Athena, back again to the beautiful maiden, with a mere suggestion of the penalty she paid to the jealous goddess (see Fig. 39). The "Medusa Rondanini" (Fig. 90), in the Glyptothek, cannot be mistaken as to its identity. The mouth and nose still show the materialism of the older artists to coarsen the features, and the rounded band under the chin cannot be misunderstood in its cruel suggestiveness, yet the expression of the face is softened and the hair clings in natural curls to the shapely head.

It is curious to note, as the centuries pass, how artists gradually changed their minds concerning Medusa and her punishment. At first in their devotion to Athena they sought to make her enemy so hideous in features that the beholder would shrink in terror, then later she lost her repulsiveness and was simply coarse and unattractive, and then again she became the beautiful woman with hair barely suggestive. But when the decadence of Caravaggio's time came, Medusa was again repul- 


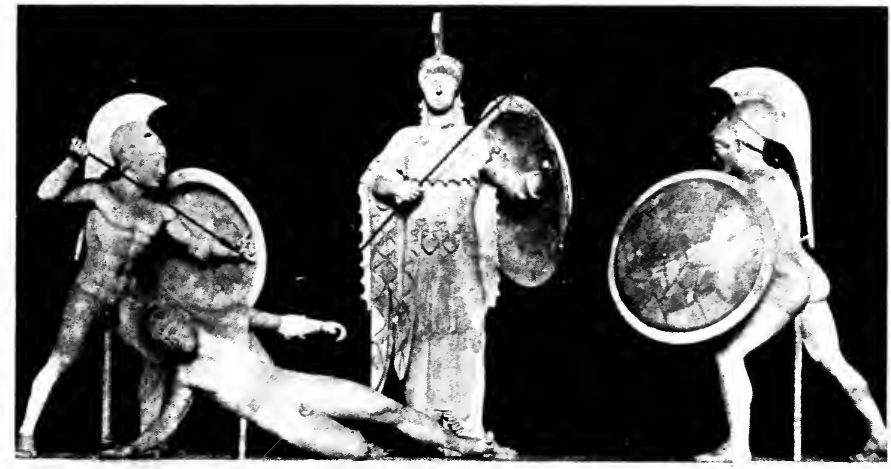

86. Athena and Warriors. East Pediment, Temple of Aigina. Glyptothek, Munich.

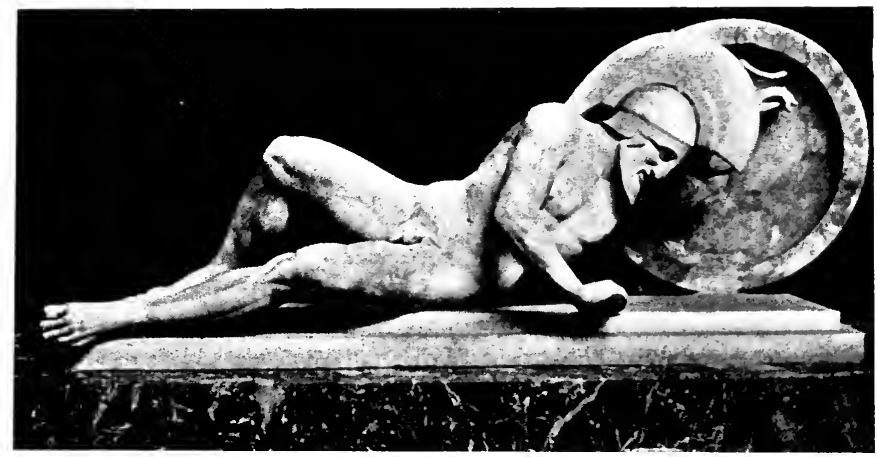

87. Fallen Warrior. West Pediment, Temple of Aigina. Glyptothek, Munich.

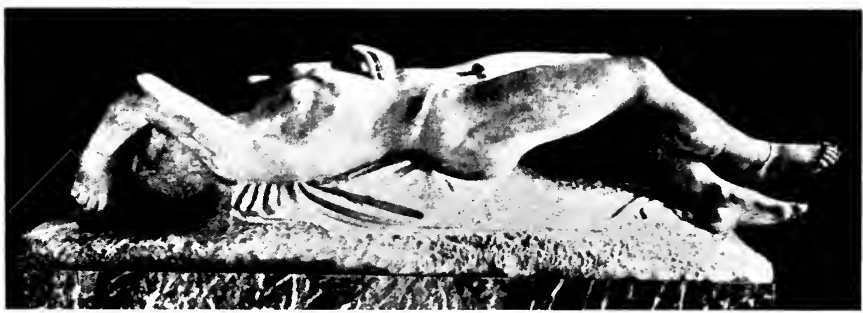

88. Dying Niobid. Glyptothek, Munich 


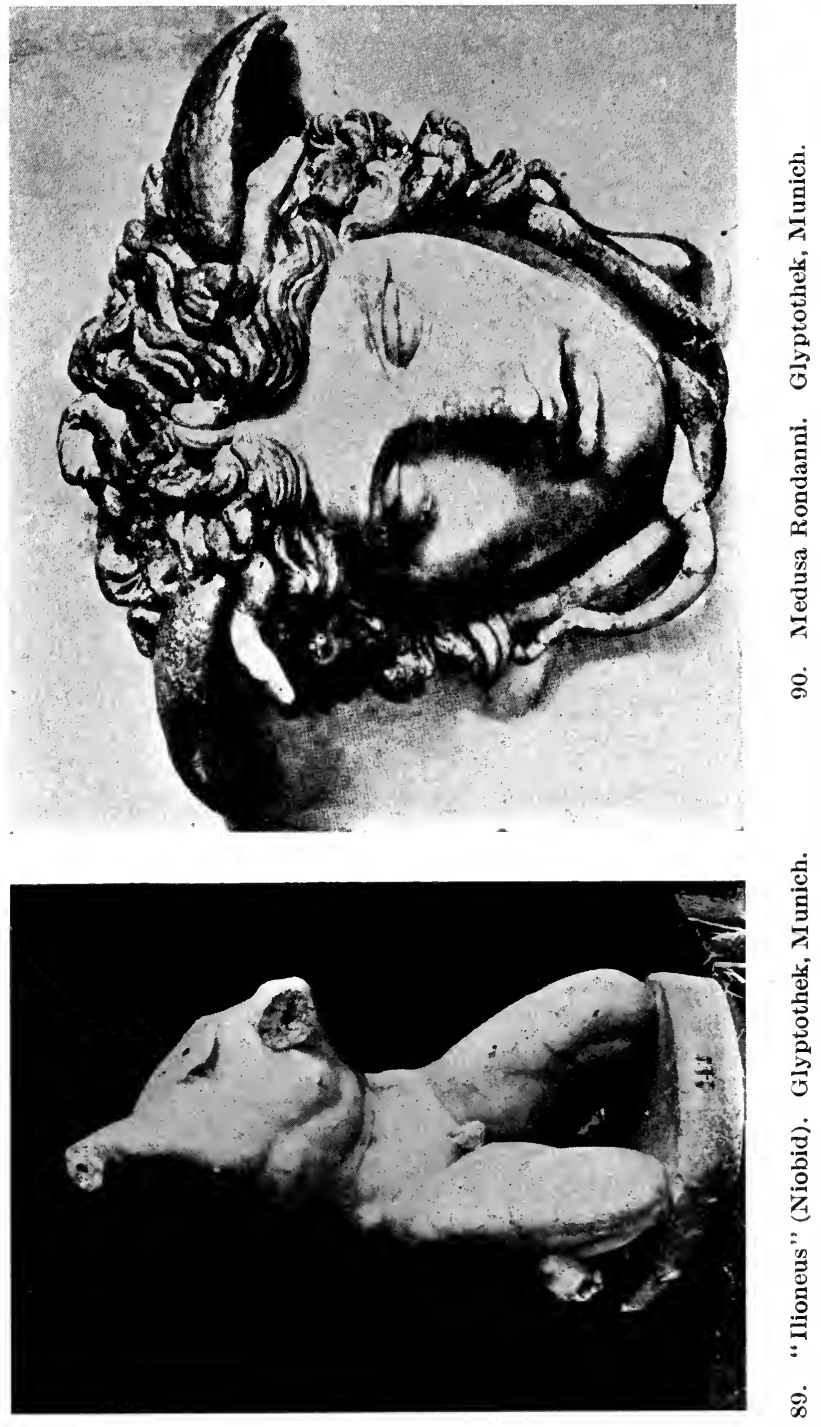




\section{MUNICH}

sively loathsome with crawling, hissing reptiles for each individual hair.

The beautiful statue of "Eirene and Plutos" (Fig. 9I) is a copy of an original by Kephisodotos, the father of the famous Praxiteles. After the battle of Leucas, 375 B. C., Eirene, the goddess of peace, was raised from a minor goddess to a very high place in the Athenian hierarchy, and elaborate ceremonials were held in her honour. It must have been shortly after this time that Kephisodotos made the statue of Eirene and Plutos, so much praised by Pausanias. This keen-witted traveller was quick to see the fitness of representing the goddess of peace with Wealth (Plutos) seated on her arm and at once recognised the intimate relationship that must exist between peace and prosperity.

Doubtless the original statue was in bronze, for many details in this beautiful Attic marble copy suggest it. Look at the folds of the drapery falling from the shoulder and the way the arm comes from under them. Also note the crisp fluffiness of the hair and the bending of one fold upon another in the garments; their clean-cut decisiveness are indicative of bronze rather than marble. What a grand, womanly woman the sculptor has made! And what tender protection he has put into the head that bends to the charming child! And what a dear little Plutos he is, too! There is much in the breadth of treatment in this group that recalls the 


\section{WHAT SCULPTURE TO SEE}

Pheidian age (see page $\mathrm{I} 80$ ) and a glimmer of the coming soul-life that Praxiteles perfected. Surely Kephisodotos was the link that bound the sublime art of Pheidias to the lovable human art of his wonderful son.

Now turn to "Silenos and the Infant Dionysos" (Bacchus) (Fig. 92), a copy of a masterpiece of Praxiteles. There is no lack of dignity in Silenos, though every line of his body expresses devotion to the little Bacchus, his pupil and foster-child. The mutual love of these two touches our hearts in its very humanness.

We can well believe that, as he grew older, the solicitude of the little god for his old schoolmaster kept him constantly on the watch for fear the old man's weakness for drink might bring him into trouble. Once after one of his drinking spells the old man wandered off and was gone eleven days. He was found by some peasants and taken to King Midas who, after enjoying his company for ten days, returned him to Bacchus. The god was so delighted to see his foster-father again that he offered to grant Midas any wish he might express. Then it was that Midas asked that whatever he touched might become gold. The wish was granted and his trouble began. Not alone stones and sticks and worthless things became gold in his hands, but his food and drink; and starvation stared him in the face. He now loathed the gift longed for, and

$$
\text { [ } 130 \text { ] }
$$



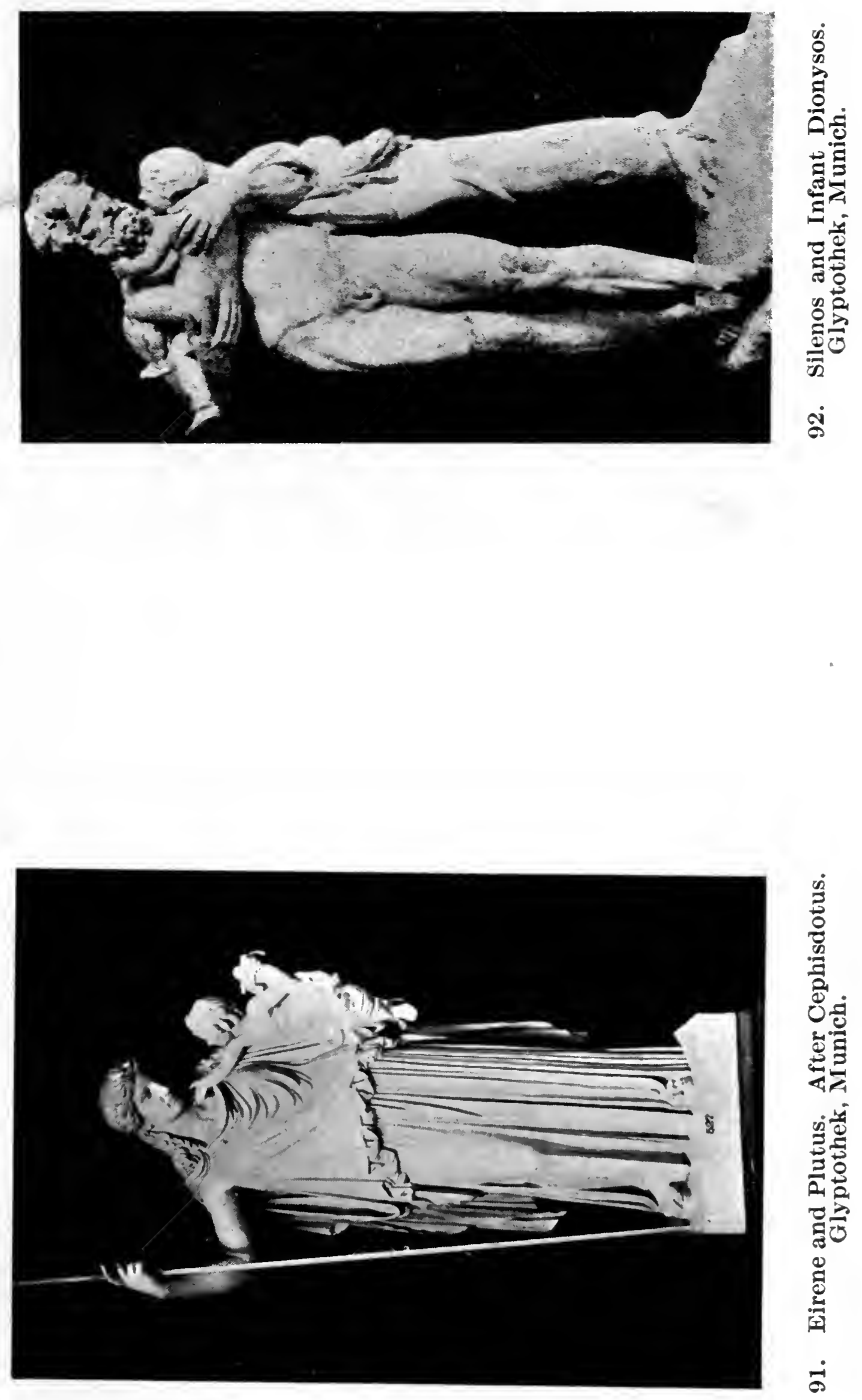


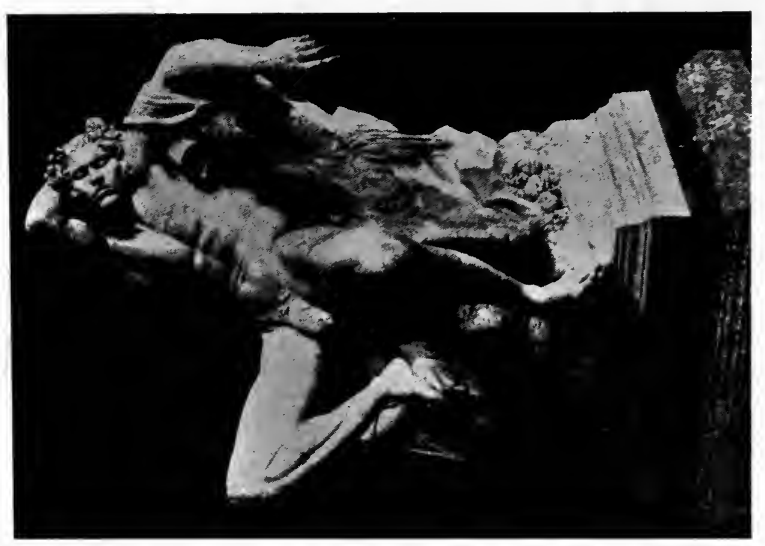

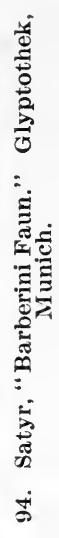

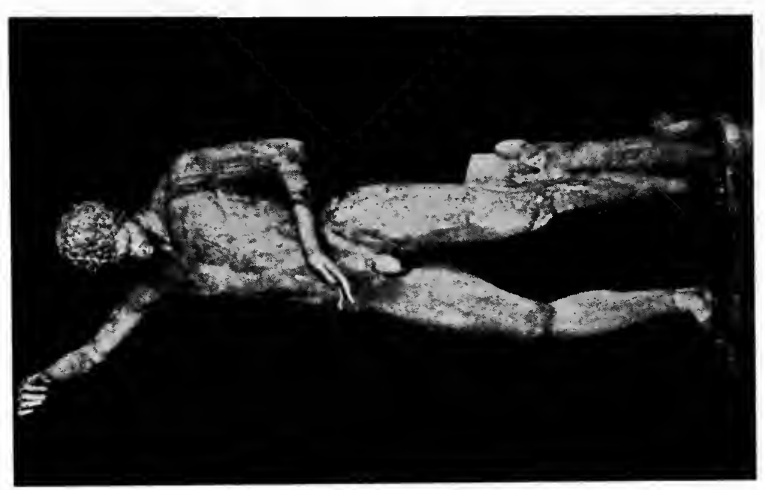

象

올

$\Xi$

풍

son

ํㅡㄹ

중옹

音

$\$$



$<$

8 


\section{MUNICH}

prayed to Bacchus in his agony. The god was merciful and answered, "Go to the river Pactolus, trace the stream to its fountain head, there plunge your head and body in, and wash away your fault and its punishment." $\mathrm{He}$ went to the river and there his gold-creating power passed into the waters, and the river sands to this day are gold.

There are many replicas of "Silenos and Dionysos," but the one in the Louvre (see Fig. II6) is the most like the one remaining original marble of Praxiteles; but more of that later.

The statue of an "Athlete Dropping Oil into his Hand" (Fig. 93) is another copy of a Myron original; also the "Discus Thrower," in the Vatican (see Fig. 22), is another (a small bronze copy of the "Discus Thrower" is in the Glyptothek) ; and "Marsyas," in the Lateran (see Fig. $5 \mathrm{I}$ ), is still another copy. It was a common practice with athletes to rub themselves with oil. The oil was dropped into the palm of the hand and applied to various parts of the body just before beginning the games. The restored right arm of the statue is unquestionably wrong, for it would be simply impossible for oil to fall into the left hand from that angle. Otherwise see how perfectly simple and convincing is the attitude of the young athlete. His attention is concentrated on the amount of oil his hand will hold-the left hand is also wrongly restored-he stands firmly on the left foot with the 


\section{WHAT SCULPTURE TO SEE}

right advanced just enough to make a firm base to steady the hand holding the oil-jar.

The artists of the Hellenistic age in Greece were quite inclined to choose their subjects from the every-day occurrences of daily life, and many times the subject itself savoured of the vulgar. This genre work, much like that of the Dutch school following Rembrandt, has brought us closer to the real life of the Greek people with its humble duties, its fantastic pleasures and its children's pain and pleasure. Such statues as the "Fisherman," in the Vatican, the "Playful Satyr" (see page I42) in Berlin, and the "Boy with a Thorn in his Foot" (see Fig. I 52 ), in the British Museum, are good examples of the skill of the genre artists.

But no statues of the school are more characteristic of the extremes of fantastic ugliness and genuine childlike fun than the "Barberini Faun" (Fig. 94) and the "Boy with a Goose" (Fig. 95).

The Faun was discovered near the Mausoleum of Hadrian (Castle of St. Angelo), Rome, while Urban VIII, a Barberini, was pope (I623-I644). It is supposed that this sprawling, ugly, drunken creature decorated the tomb of Hadrian-a strange emblem for a sober, upright emperor, unique for his goodness in an age of corruption. At the siege of Rome under Totila the Ostrogoth ( 544 A. D.), the statue was thrown into the Tiber, and when brought to light the left forearm, most of the right

$$
\text { [ } 132 \text { 2] }
$$




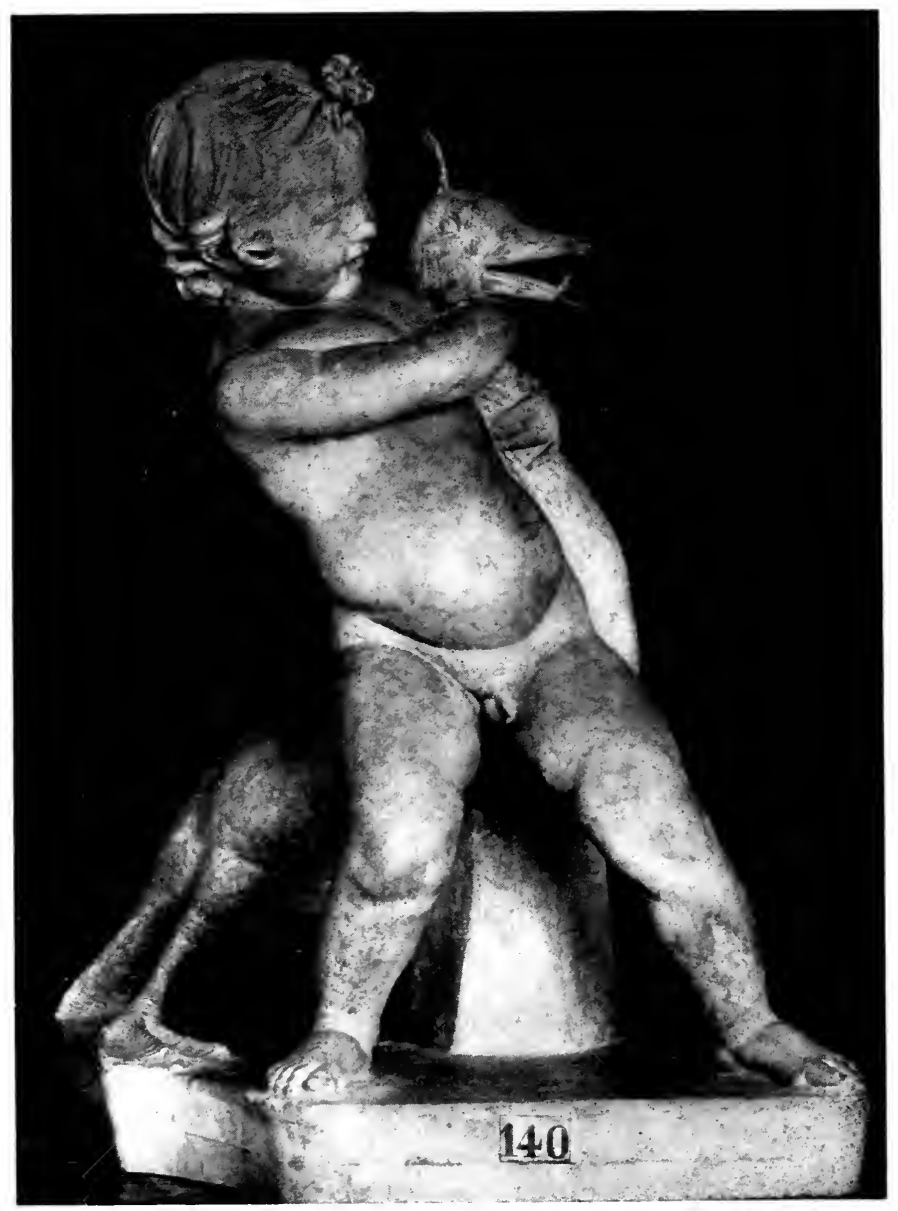

95. Boy with Goose. After Böethos. Glyptothek, Munich. 


\section{MUNICH}

leg and the lower part of the left leg were missing. There is no question but that the creature is hideous, but look at the superb work. Like Jan Steen's "tavern scenes" of dissipation and debauchery, the disgusting subjects are forgotten in the marvellous magic touch of the artist. Truly he has transformed a thing ugly in itself to a marvel of beauty and joy.

Now feast your heart again on the "Boy and the Goose" (Fig. 95)! He is a darling, and well worth a second picture (see Fig. 26). We realise that the artists are getting away from the great art of Pheidias and Praxiteles and that decadence in art has begun; but this last effort, in the ending centuries before the new spirit came, has brought us closer to human life. We need the classic ideals of old Greece and we also need Boëthus and his bewitching children of the home. 


\section{CHAPTER XIV}

\section{BERLIN}

A STRANGE coincidence occurred at PergaA mon when the fragments of the great Temple of Zeus, now in the Berlin Museum, were discovered by accident in the seventies. As the excavators were climbing the mountain ready for their task, above their heads circled eagles, the god's own birds, as though directing them where to find statues of the great Zeus and his attendants, and when the fragments came to light not only Zeus and his galaxy were there, but eagles, brothers of the wild birds circling in the blue ether above the workmen. They were pictured assisting the great god, bringing the thunderbolts and helping dispatch the enemies with beak and talons.

The great altar at Pergamon had been lost to the world for centuries; in fact, its very existence was forgotten. The reference in Revelation ii. I2, I3, "And to the angel of the church of Pergamos write, I know where thou dwellest, even where Satan's throne is:" lost its real meaning when these marbles were hidden and unknown. Just when they disappeared, no one knows. Pausanias, in the

$$
\text { [ r34 ] }
$$




\section{BERLIN}

second century A. D., refers incidentally to a great altar at Pergamon and another little known author of the same century mentions a marble altar at Pergamon fifty feet high with large figures fighting, as among the great wonders of the world. There is little doubt but that its destruction was due to the mistaken zeal of the early Christians. To them an altar to Zeus was indeed the throne of Satan. Many of the reliefs built into walls of houses and fortifications, were found in a fine state of preservation, except that the gods in most cases were minus their heads. This argues that to the Christians the heathen gods were all looked upon as enemies of the one true God, and that they had no appreciation of this great work of art, as it illustrated the contest of right and wrong between the heavenly deities and the earth-born giants. But was this mistaken zeal any stranger than the iconoclastic movement in Europe many centuries later?

The Pergamon altar was built during the reign of Eumenes II (197-I59 B. C.), in the Autumn days of Greek sculpture, yet with no abatement of artistic skill. Fortunately the fragments preserved in the Berlin Museum have not been marred by the restorer. Broken and fragmentary the pieces are, yet a number of individual figures stand out clearly, and others in part, so that one can get some conception of what the altar must have been in its

$$
\text { [ } 135 \text { ] }
$$




\section{WHAT SCULPTURE TO SEE}

pristine perfection. One of the most beautiful of the single figures is that of "Selene on her Horse" (Fig. 96). Selene, the goddess of the moon, sits calmly overlooking the combat of the gods with the giants. Were it not that the strained muscles and raised tail of her horse and the fluttering end of her outer mantle suggest rapid motion one might think that the pale goddess was simply waiting in the distance the outcome of the battle. But the sharp turn of her eager head and her raised right arm show how intense is her interest, though her body is calm and controlled. What an exquisitely beautiful neck and shoulder! The firm velvety skin pulsates with life. Look at the yielding quality of the healthy flesh under the narrow girdle. Did the folds of a loose robe ever cling more lovingly to a beautiful human form? or did living flesh ever respond to the gentle swell of the lungs more perfectly? This goddess of the moon is altogether one of the most alive beings in all art -a masterpiece of womanly charms.

What a pity that most of the gods of the Pergamon marbles should have so little left to distinguish them. But of "Dionysos" (Fig. 97) we are quite sure, for by his side is his panther, and part of the chaplet of vine leaves still cling to his flowing locks.

The story of Dionysos as told by Acetes explains how the panther became one of his attend-

$$
\text { [.136 ] }
$$




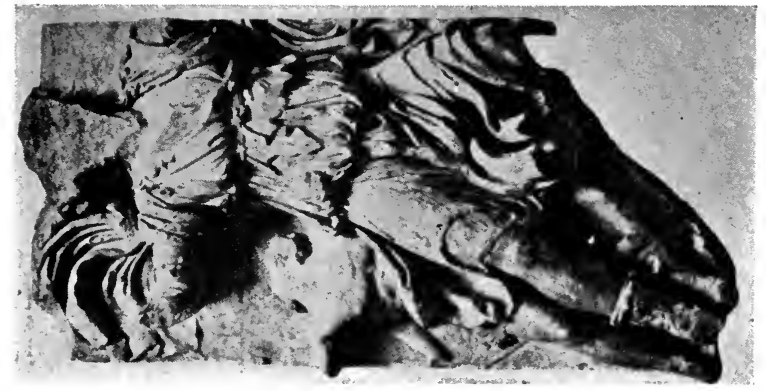

몽.

ஸ்

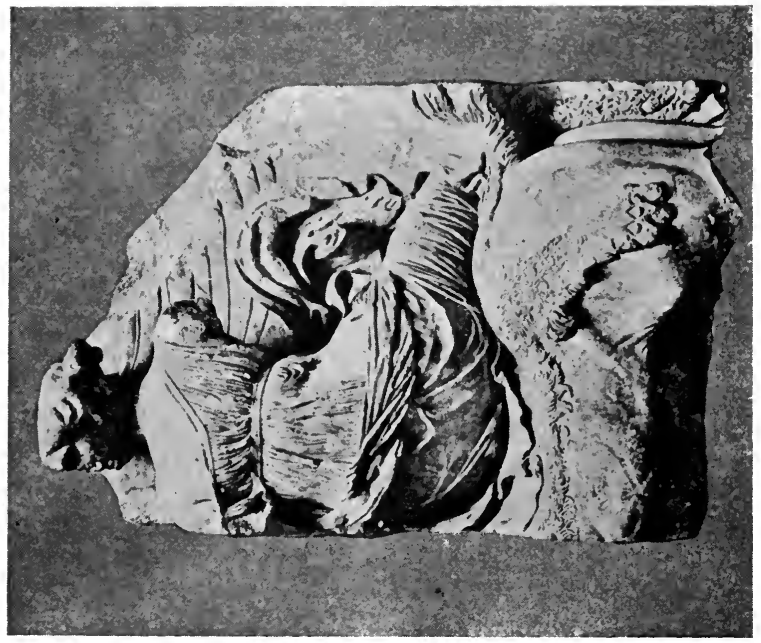

อ

离葛

동ํㄹ

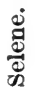

$\stackrel{8}{\circ}$ 


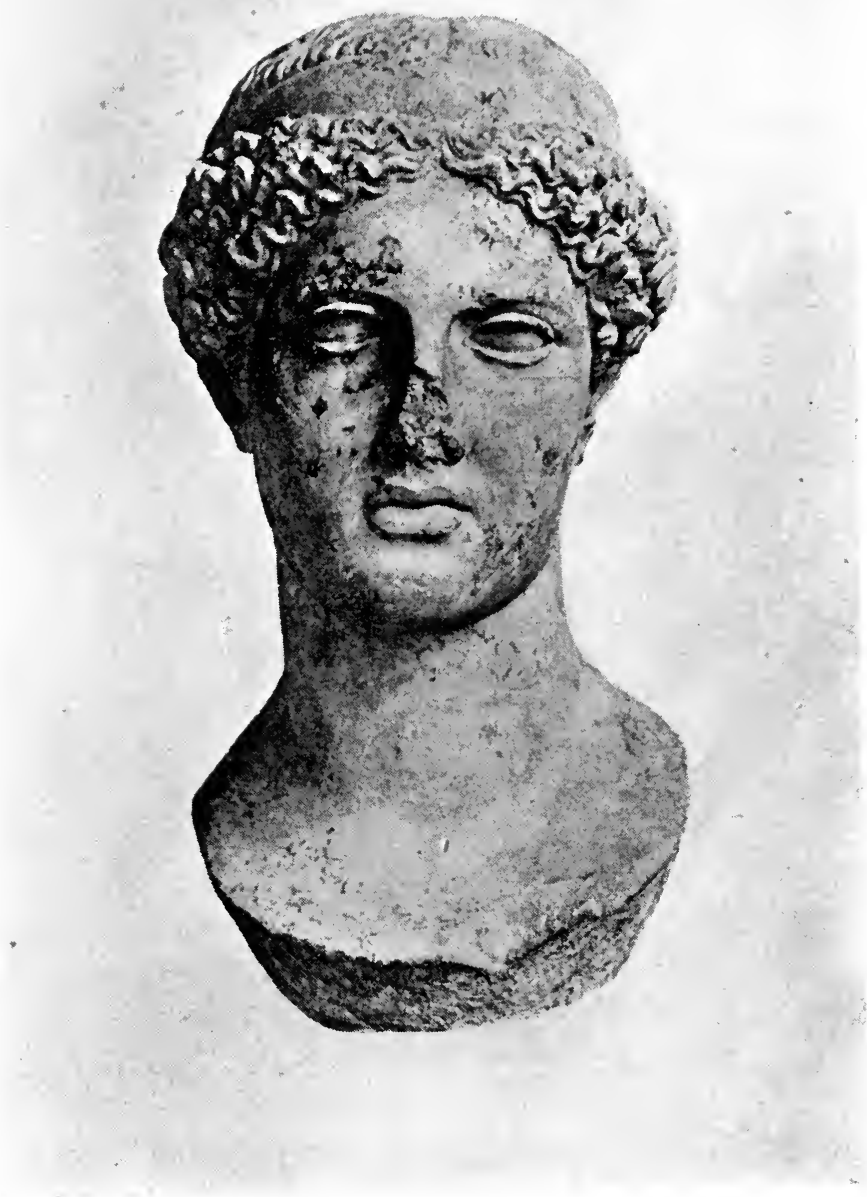

98. Bust of Aphrodite. Pergamon Museum, Berlin. 


\section{BERLIN}

ants. When Dionysos was a youth he was stolen by some sailors, as he slept. They thought to sell the beautiful boy as a slave into Egypt, and instead of sailing toward Naxos, as the god requested, they steered toward the country of the Nile. But Dionysos aroused himself-he had been in a kind of stupor-looked about and cried, weeping,

"Sailors, yonder island is not my home. What have I done that you should treat me so?" Suddenly the vessel stopped as if rooted to the place; vines sprang up covered with clusters of grapes; the sailors were changed into dolphins, except Acetes, the narrator of the wonderful scene; tigers crouched at the feet of Dionysos and panthers and lynxes played around him. The god commanded Acetes to steer the vessel to Naxos, and there the altars were kindled and the sacred rites of Dionysos (Bacchus) were celebrated.

It is a little strange that the pleasure-loving god should be in the thick of the battle, and in a fight for right too! He is accompanied by his satyrstwo can be traced in the fragments. Every detail of the god's apparel is portrayed with the artistic touch of a master hand. One can feel the fine texture of his clinging garments, especially where they escape from beneath the nebris, or faun-skin at the waist and shoulders, and fly out against the panther and the leather aprons of his satyrs. No Venetian artists have shown greater skill in imi- 


\section{WHAT SCULPTURE TO SEE}

tating stuffs than have these Pergamon sculptors with brushes of steel.

The "Aphrodite Head," in the Pergamon Museum (Fig. 98), is a treasure of rare beauty. It is undoubtedly a Greek work, and may be a copy of an Aphrodite by Alcamenes, the pupil and contemporary of Pheidias. It is made of Parian marble and has not been touched by the restorer. It has that quality of workmanship which points to Attic work at its best. Though the head was bought in Rome in 1873 , it no doubt originally came from Greece. Many details of this precious bit of marble remind one of the Aphrodite, or "Venno Genetrix," in the Louvre (Fig. I08). The close waving hair lying low on the broad forehead, the oval of the face and the exquisite mouth mark a lovable woman, while the calm, steady, deeply sympathetic eyes command respect. There certainly is a charm in this broken treasure that only a master hand can give, and if the master of the original was Alcamenes he was second only to Pheidias, according to Pausanias. Alcamenes was a native of Attica (born at Lemnos or Athens) and lived about 448-404 B. C. He was known to have made two Aphrodites, and the more celebrated of the two was made for a garden outside of Athens, hence called "Aphrodite of the Garden."

The "Pergamon Copy of Athena Parthenos" [ 138 ] 


\section{BERLIN}

(Fig. 99) may give us a faint idea of the imposing grandeur of Pheidias' famous statue of the goddess of Athens. Of all the important statues of Pheidias' time-we have none of them to-day - probably no single one has been mentioned more often by art critics and antiquarians of antiquity than Athena Parthenos. When the Parthenon, the temple of Athena, was finished, the highest commission that could possibly be given any artist was to execute a statue of the virgin goddess for the shrine of her new temple in Athens, and Pheidias was given that commission. That he far surpassed any work of his predecessors is asserted by all writers. The statue, more than six times the height of a man, was made of wood overlaid with pure gold and ivory and decorated with precious gems. In 437 B. C. the goddess stood complete in her own shrine in the Parthenon, but as early as 397 B. C. it needed repairs, though the precaution had been taken of wetting the wood to keep it from shrinking in the dry air of the Acropolis. A hundred years later ( 297 B. C.), the tyrant Lachates despoiled the goddess of her precious drapery, but fortunately having to flee from his enemies disguised as a peasant, he probably carried away but a small portion of the rich material. Pausanias writes in the second century A. D. of seeing the statue fully draped in gold, and in 375 A. D. it is reported still in Athens.

$$
\text { [ I39] }
$$




\section{WHAT SCULPTURE TO SEE}

It seems impossible for us to gain much idea of the real grandeur of the statue of Athena Parthenos, for even Pliny declared he was unable to do justice to any of the great works of Pheidias, and simply contented himself with giving descriptions of minor decorations of the great goddess. We stand before the Pergamon copy and wonder how anything so colossal in size could be made to embody so much of the charm of womanhood, and if this is so of a simple copy in marble, what must have been the original, with its glory of gold and ivory and precious gems, transformed into a goddess by the great master Pheidias. In 1880 , in repairing a street in Athens, a statuette was uncovered which is unquestionably the most perfect copy in miniature of the Athena Parthenos. It is scarcely three feet high, but has the exact proportions of Pheidias' statue, as given by ancient writers. The statuette is in Athens.

In the Old Museum, in Berlin, we are attracted at once by the beautiful statue of "An Amazon," after Polycletos (Fig. 100). Pliny tells the story that when Amazon statues were required for the temple of Artemis at Ephesus, in the fifth century, all the noted sculptors of the time sent in work, and Polycletos won the prize over Pheidias. This story may be simply an anecdote, yet this marble copy of an Amazon is the most important statue of all the representations of the female warriors.

$$
\text { [ } 140 \text { ] }
$$



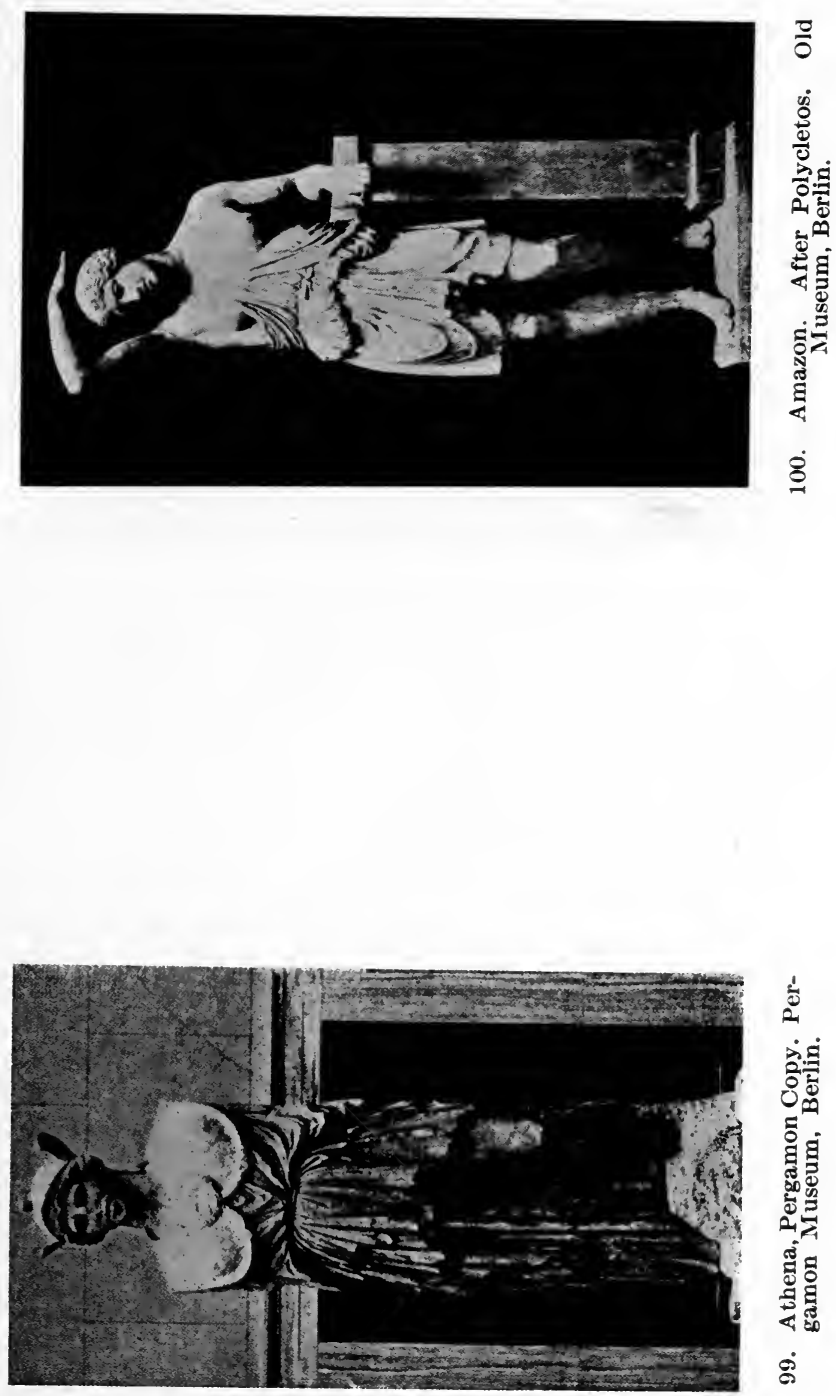

2.

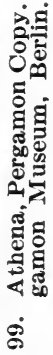




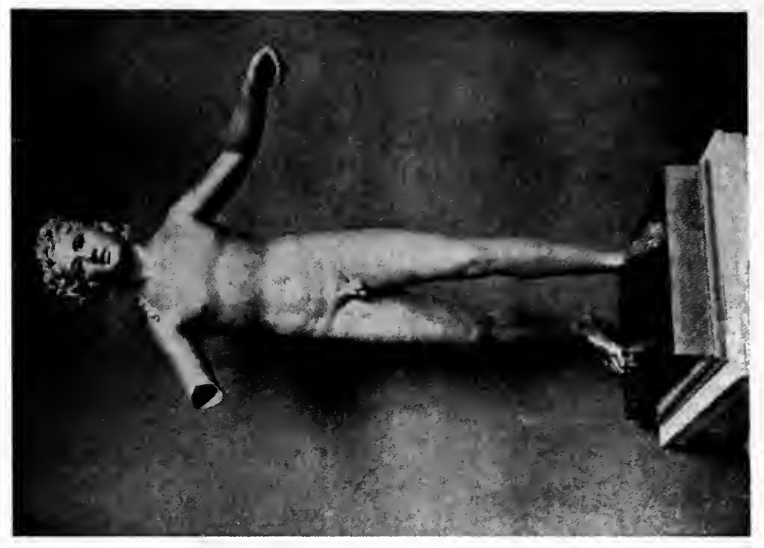

造

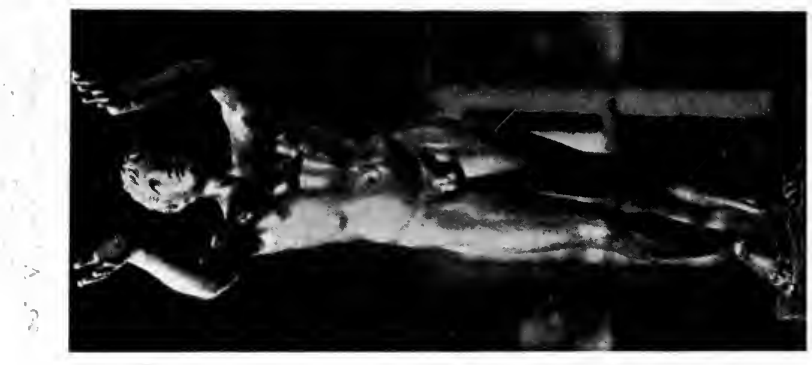

$\frac{1}{4}$

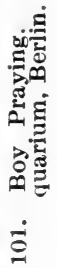




\section{BERLIN}

Whether it is a direct copy of Polycletos or not, it is impossible to know, but certainly the graceful, well-proportioned, vigorous lines of this beautiful woman accord well with the Polycleton type. The expression of pain on her face and the bleeding wound on her right side tell plainly that she has been in the fray, yet she asks no pity as she rests her weight on the pierced side and opens the wound afresh by raising her right arm over her head. She shows both a determination to ignore the hurt, and, though resting for a moment, a will to return to the thick of the fight. Her attitude bespeaks one who has withdrawn from the fury of the contest, with flesh torn and garment clasp broken, only to enter again later. Beautiful she certainly is in her heroic courage and feminine grace. Several artists, in their copies of the Amazon warriors, have sought to lessen the heroic in her disregard of pain by shifting the weight of her body to the left leg, lowering the straining arm and draping the body to conceal the wound, as seen in the Vatican and Capitol copies in Rome. But by doing so they have deprived the brave warrior women of the strength of their convictions and have aroused in the beholder a feeling of contempt for their weakness rather than of admiration for their courage.

In the Antiquarium of the Old Museum is "The Praving Boy," after Lysippus (possibly by his son 


\section{WHAT SCULPTURE TO SEE}

Boëdas) (Fig. IOI). It is believed that in this boy is reproduced a universal custom among the ancient Greeks, that of prefacing every act with prayer. Homer says the heroes "stretch their hands to the gods" and "look up to heaven." The suppliant always stood with head uncovered and open hands. The position of the arms indicated what gods were appealed to; if of heaven, they stretched upward; if of the sea, they were stretched forward; if of the underworld, they beat the ground to attract the god's attention. This lifesized statue, probably an athlete, is an almost untouched original Greek bronze of the finest quality. The metal is so thin that the statue can be easily carried by one man-quite different from the Roman bronze boy of the same size (Fig. 102), that takes four men to move. There is a certain exaltation of pose and manner in this simple boy that lifts our minds with his to a higher power, a universal instinct in humanity.

The "Running Boy" (Fig. I02) was found near Xanten in the Rhine. It is of Roman bronze and lacks the quality of life that fills the figure of the "Praying Boy." The pose is stiff and awkward, yet there is an eagerness in the lifted head that is very boyish. It evidently belongs to the early Imperial period of Rome.

Do not fail to see the bronze "Playful Satyr" from Pergamon. The little fellow is only six

$$
\text { [ } 142 \text { ] }
$$




\section{BERLIN}

inches high, yet so full of the spirit of mischief that we laugh at his antics in spite of ourselves. Small as he is, he reminds us of Myron's "Marsyas" (Fig. 5I), but the later artist has given a thoughtless playfulness to his wee figure like that of the child or veritable woodland sprite. The coarse, ugly face of the little imp is lighted up with a merriment so genuine that we attach no malice to the fisticuffs he is delivering right and left. 


\section{CHAPTER XV}

\section{PARIS-LOUVRE}

T F we could be transported from the stem of an 1 ocean steamer at full speed to the entrance hall of the Louvre, Paris, and there catch our first view of "Nike of Samathrace" (Fig. IO3), we would continue to feel that thrill of exaltation which springs from unimpeded motion. Even stepping from the street into the presence of this superb creature, we are lifted out of the sordid commonplace, and all life offers to us untold possibilities.

Nike of Samathrace was set up by Demetros Polioketes of Macedon to celebrate his naval victories over the Egyptians in 306 B. C., but who the sculptor was is still unknown. The victor, following the tradition of the Greeks that when a victory had been won at sea, Nike, the goddess of Victory, came down and lighted on the prow of the ship and guided it to its native shores, placed this wonderful statue on the seashore of the island of Samothrace. There her right wing ever pointed to the sea and her left toward the temples and long colonnaded walks where statesmen and pleasureseekers were wont to gather. 


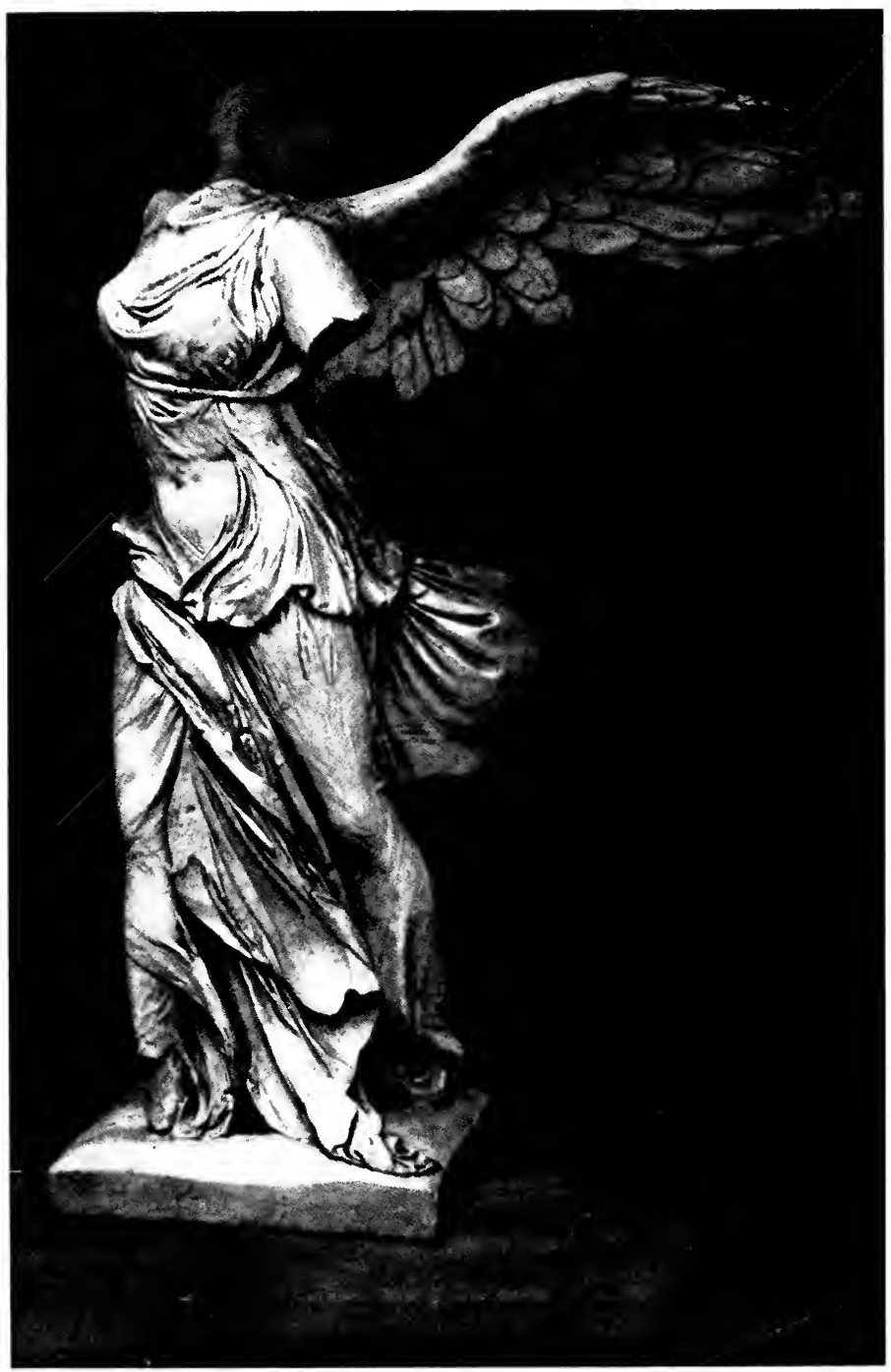

103. Victory of Samothrace. Louvre, Paris. 


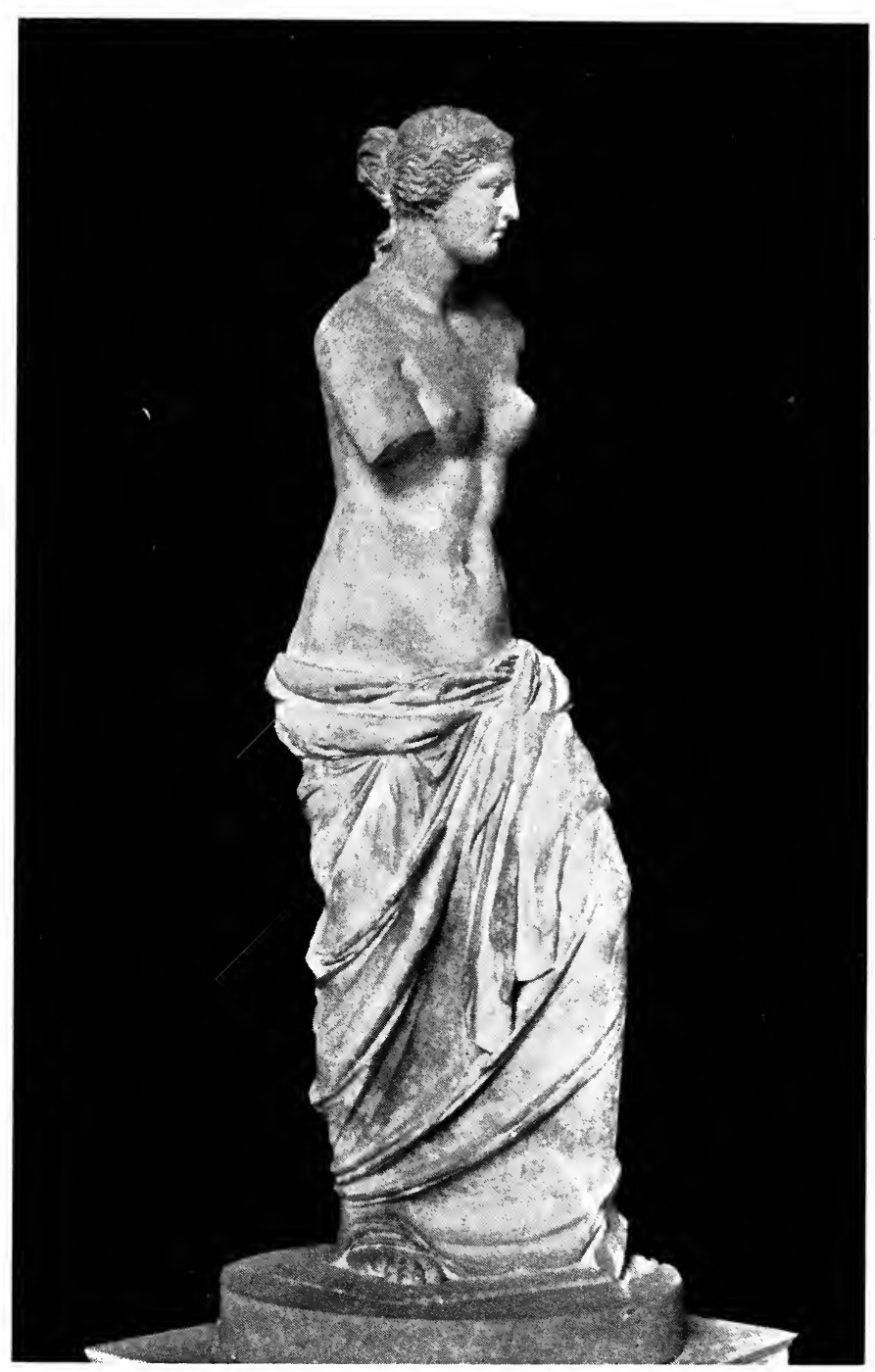

104. Venus de Milo. Louvre, Paris. 


\section{PARIS}

The statue was discovered by the French consul Champoisseau, on the ancient site in 1867 . Only fragmentary pieces of the goddess were found and not until I875, under an Austrian expedition, did the pedestal come to light on the same site. Looking at the goddess carefully you will find that only the left side is really finished, as that side faced the spectators, and the back is simply blocked out, for the statue was in front of a high wall that crossed the end of the valley. There she stood, this colossal goddess of Victory, towering above the buildings and dominating the sea and the valley spread out before her. What a thrill of pride these Samothracians must have felt when such a magnificent goddess of Victory alighted on their shores. Words are too feeble to describe this masterpiece; only individual souls feel her impelling force, a force that beckons each individual to the highest achievement and is satisfied only with perfection. Nike is a most fitting piece of art to introduce you to the treasures of the Louvre gallery and equally fitting as a finale. Study her well, and then stand quietly and let her influence envelop you until the exaltation of victory is yours too.

And now let us turn aside to the left and enter the long hall at the foot of the stairs. You can see her in the distance, that beautiful goddess of Love, "Aphrodite of Melos," or "Venus de Milo" (Fig. 104). She is well worth crossing the ocean

$$
\text { [ } 145 \text { ] }
$$




\section{WHAT SCULPTURE TO SEE}

to see! She stands alone in the end room and glows with perfect health against the low tone red walls that surround her. In this lovely being is combined all that makes a perfect woman-some particular perfect woman that we all know personally. We look into her eyes and feel that truth dwells there. Her mouth might chide but never with injustice. She has power, yet her sense of proportions in the things of life would govern her actions. We love her, we revere her, and we claim her as our friend.

The Aphrodite of Melos was found in 1820 by a peasant in a grotto in the island of Melos. The statue was broken into two parts, and with it were a left arm and hand, but critics still disagree as to the latter belonging to the statue. The goddess was sent as a present to Louis XVIII of France. No end of controversy has been waged over the position of the arms of Aphrodite, but as no one knows how they were originally, she thus far has been left in peace. One tenable theory that accounts for the lack of marks of support for the arms on the statue (their weight in marble required one) is that she stood in a niche with arms supported against the sides, and that she faced as in the illustration. This position reveals the fascinating curl in her neck and hides the ungraceful straight line of the left side.

The drapery of the Aphrodite of Melos pro-

$$
\text { [ } 146 \text { ] }
$$




\section{PARIS}

vokes endless discussions as to its position and ampleness: it is dropped too low to be secure, says one; it is too scant for a garment, asserts another. But while these questions still remain, possibly they have brought us nearer her age. If she were as old as the Parthenon marbles, her drapery would be full and secure: if she were a product of Praxiteles' prime, no thought need be given to drapery; but if she belongs to the "Autumn" days when Greek artists absorbed, Raphael-like, the best of all time and produced originals par excellence, her drapery needs no apology, for the sculptor's use of drapery was simply to enhance the beauty of the whole. In the words of August Rodin we will sum up the charms of Aphrodite of Melos:- "Thy verity is within the range of all: it is a woman, whom each one thinks he knows, the familiar companion of men; but no one has seen her, the wise men not more than the most simple."

The "Aphrodite of Arles" (Fig. I05) may have come from under the influence of Praxiteles. The drapery here is frankly a garment with texture and folds of the days of Pheidias, while the face and arrangement of the hair have a slight resemblance to Phryne. Possibly Praxiteles, early in his career, may have made an Aphrodite like this one. The statue was found at Arles in Provence, France, in I65 I.

But in the "Apollo Sauroktonos" (Fig. I06) we [ I 47 ] 


\section{WHAT SCULPTURE TO SEE}

have a copy, though an inferior one, of a genuine Praxiteles. If you will compare this statue with the one in the Vatican (Fig. I6), you will see at once that the copyist in making the tree merely a support, has detracted from the true meaning of the tree as a vital part of the composition. In the original bronze figure no attachment being necessary, the full grace of the pose could be attained only by a wide distance between the figure and the tree. Copyists seemed to lose sight of this essential, and in the Dresden Apollo Sauroktonos the faun fairly hugs the tree-trunk.

The "Athena of Velletri" (Fig. 107) is a Roman copy in marble of a Greek bronze. It is placed as far back as the fifth century B. C. by some authorities, but even the small sized ægis would contradict this. In very early Greek works the ægis was more like a garment on the warriorgoddess; even the statue of her on the Aigina temple marbles (Fig. 86) shows it falling below her breasts and half way to the ground in the back. Again in the Athena Parthenos it covers the breasts and drops over the shoulders, but in the Athena of Velletri it is scarcely more than a narrow collar of coiled snakes, with the Medusa medallion in the front. Again the drapery has very little of the broad treatment of Pheidias, and the cross folds are too studied to be the work of a great master of the time of Pheidias. The statue was named 


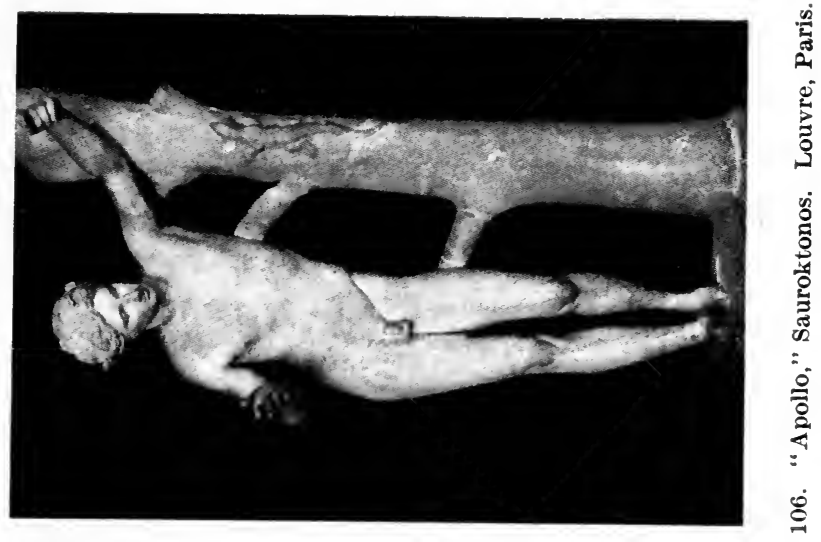

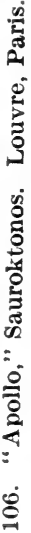

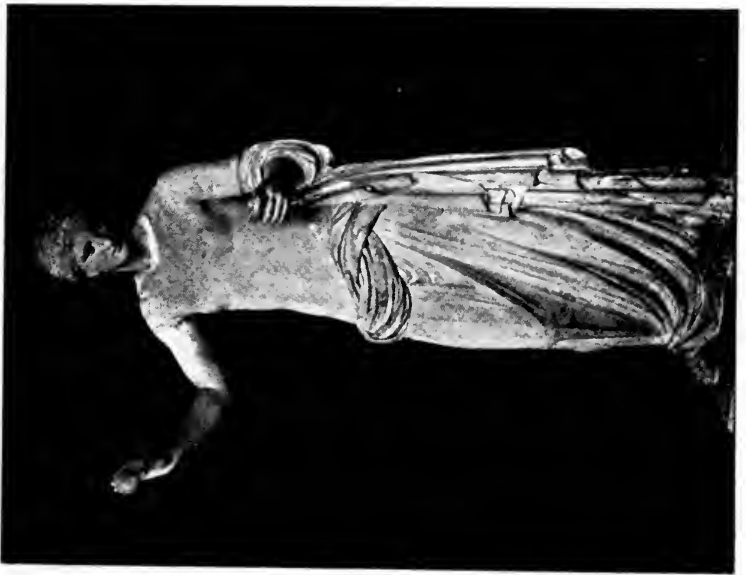

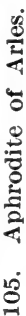



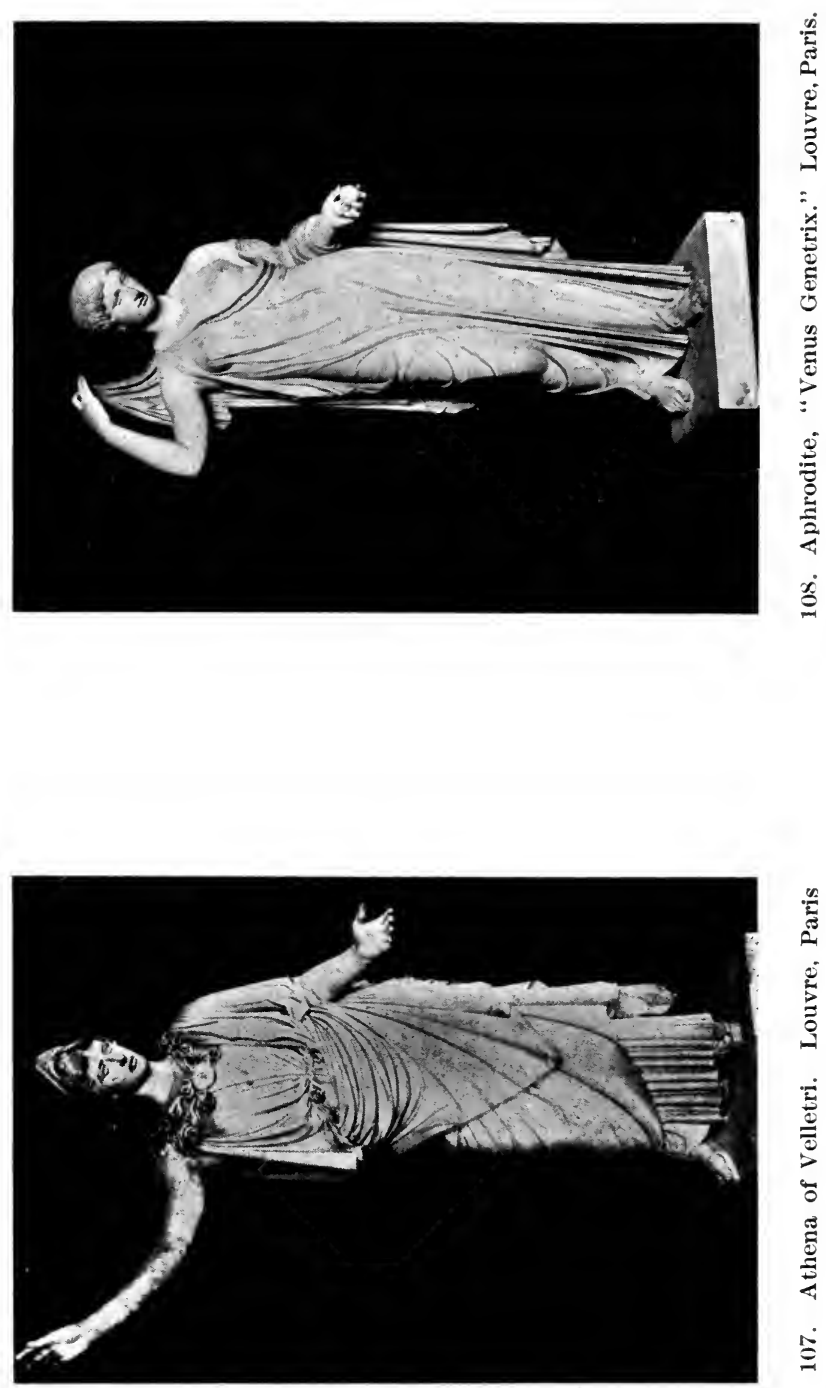


\section{PARIS}

Valletri because it was found in that place, near Rome, in 1797.

It is possible that "Aphrodite or Venus Genetrix" (Fig. I08) of the Louvre is a Roman copy of the celebrated draped Aphrodite of the Garden by Alcamenes. Some critics, however, claim it is a copy of the famous Venus Genetrix, made by Arcesilaus for the Forum of Julius Cæsar, for coins of the Imperial period have a figure on them that corresponds to this statue. However this may be, we are bound to recognise that the mind of a master originated this Aphrodite, whoever executed this copy. Compare the untouched head of this statue with the exquisite head of Berlin Aphrodite (Fig. 98), and you will see how close is the resemblance between them. The same close-bound wavy hair, the same depth of feeling in the eyes, and the same sweetness and strength in the mouth and chin. Look at the long sweeping lines of the drapery and note how it reveals, yet covers, the graceful curves of her body. At least this Aphrodite, repeated so many times in the various museums, must shadow forth some famous statue of the golden age of Greek art.

If, as a recent inscription permits us to believe, Agasias, the sculptor of the "Warrior Borghese" (Fig. ro9), can be put in the time of Pergamon's glory rather than the first century B. C., we can better account for the decided resemblance of this

$$
\text { [ } 149 \text { ] }
$$




\section{WHAT SCULPTURE TO SEE}

warrior to those on the Pergamon frieze. With mouth open and determined blows he is probably calling to an associate, and fighting an assailant on horseback close at hand. The hero has all the eager enthusiasm of the primitive in fight, yet coupled with the restraint of the trained warrior. We feel, as in the Pergamon marbles, that if this figure could be in its proper setting with comrades and assailants, its attitude, so strained in a single figure, would simply fit in as part of a whole in a group. The statue was found in an imperial palace at Atrium, near Rome, and once belonged to the Borghese family.

Poor "Marsyas" (Fig. I IO) is here undergoing the punishment he brought on himself by his unwise challenge to Apollo. If you will place the illustration of the "Slave Sharpening his Knife" (Fig. 58) by the side of Marsyas in the Louvre, you will find how well the two figures explain each other. So realistic is this story told by chisel and by pen that we have the deepest pity for poor Marsyas; he was childlike in his boasting. It is quite certain that these two statues. belong to the Hellenistic age, or possibly to Pergamon itself; they resemble the latter in many points. The anatomy of poor tortured Marsyas is perfect; his agony causes us to shudder, yet no distortion of body or exaggerated show of suffering offends us; only his satyr-like face is pitiful in its dumb appeal.

$$
[\mathrm{I} 50]
$$



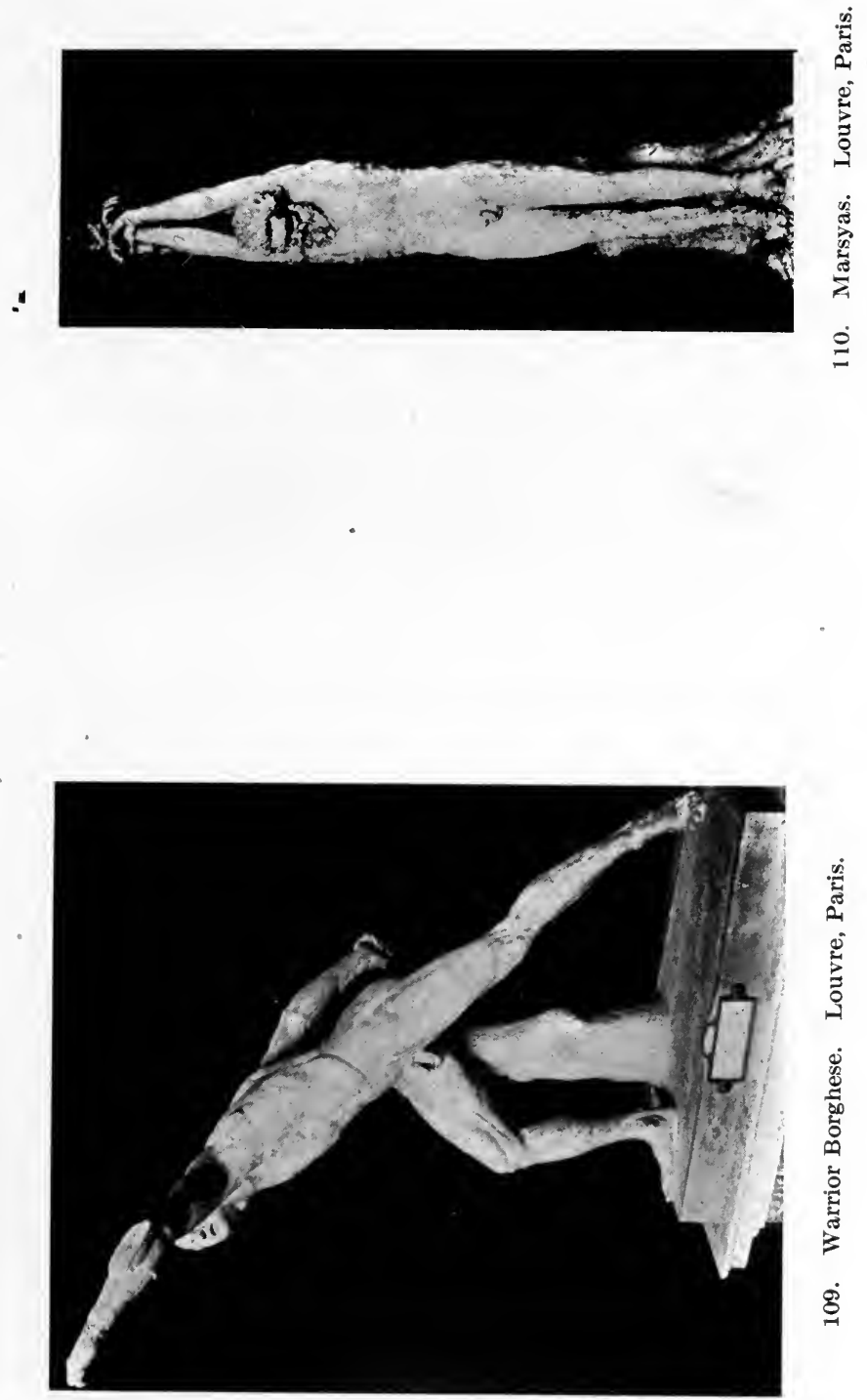


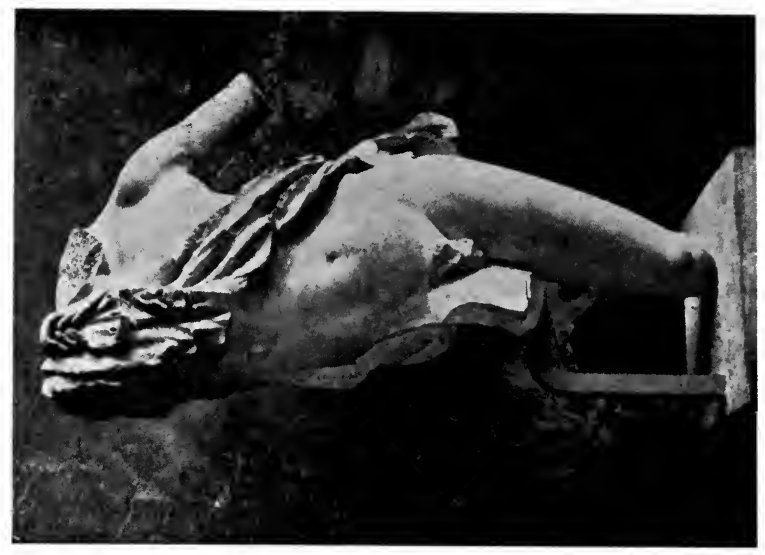



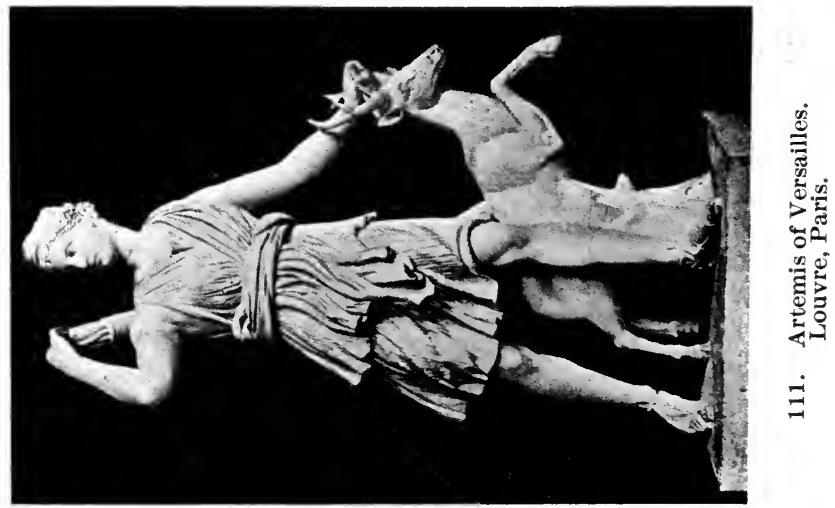




\section{CHAPTER XVI \\ PARIS-LOUVRE (Continued)}

T $\mathrm{T}$ seems a great pity that the brother and sister, 1 Apollo and Artemis, could not stand side by side in a museum. "Artemis of Versailles," in the Louvre (Fig. I I I), might suffer in excellence of workmanship with the "Apollo Belvedere" (Fig. I2), yet some contend that Apollo is of Italian Carrara marble while Artemis is of Greek marble, and probably a replica of a work of the time of Praxiteles. But the statues are so alike in size and sense of rapid motion that their execution point to the same period of time. The sense of unrest that one feels in looking at these beautiful beings, for they are very beautiful in bodily perfection, leaves one disquieted. It is like watching a race; there is exhilaration, but no rest until it is over. We are filled with admiration over the softly rounded limbs, the swelling bosom and the pulsing lifeblood that quivers in every tissue. Even the surrounding breezes feel the onward force of the huntress, as they play with her short tunic and lift it to reveal the shapely knee. One is not surprised that this goddess, with her keen-eyed, unsmiling

[ I 5 I ] 


\section{WHAT SCULPTURE TO SEE}

face, could punish without mercy when molested. You may remember poor Actæon, and how he unwittingly surprised the goddess and her nymphs in their secret dell. To punish him she dashed water in his face, saying:-

"Now go and tell, if you can, that you have seen Artemis unapparelled." The words were scarcely spoken before from his head sprang wide branching horns and his limbs became legs with hoofs for feet, his neck grew long and his body was covered with a spotted hairy hide. A sudden fear seized him as he sprang away and fled. His consciousness remained, and when he caught a glimpse of his horns in the water and realized that his speed was that of a stag, he tried to cry out, but no sound came. What should he do? As he waited, his hounds spied him, and thinking him the stag they had been hunting, started again in pursuit. He fled, but his fifty hounds were too much for one poor trembling stag. He groaned and tried to make himself known to his faithful dogs, but how could he? There was nothing human about him but his consciousness. They tore him to pieces, and then, Apollidorus says, the dogs died of grief because they could not find their master.

In the same room with "Artemis" is the "Resting Satyr" (Fig. I I2), after Praxiteles. This is another "Marble Faun" similar to the one we saw in the Capitol, Rome (Fig. 32). This fragment

$$
\text { [ } 1552 \text { : }
$$



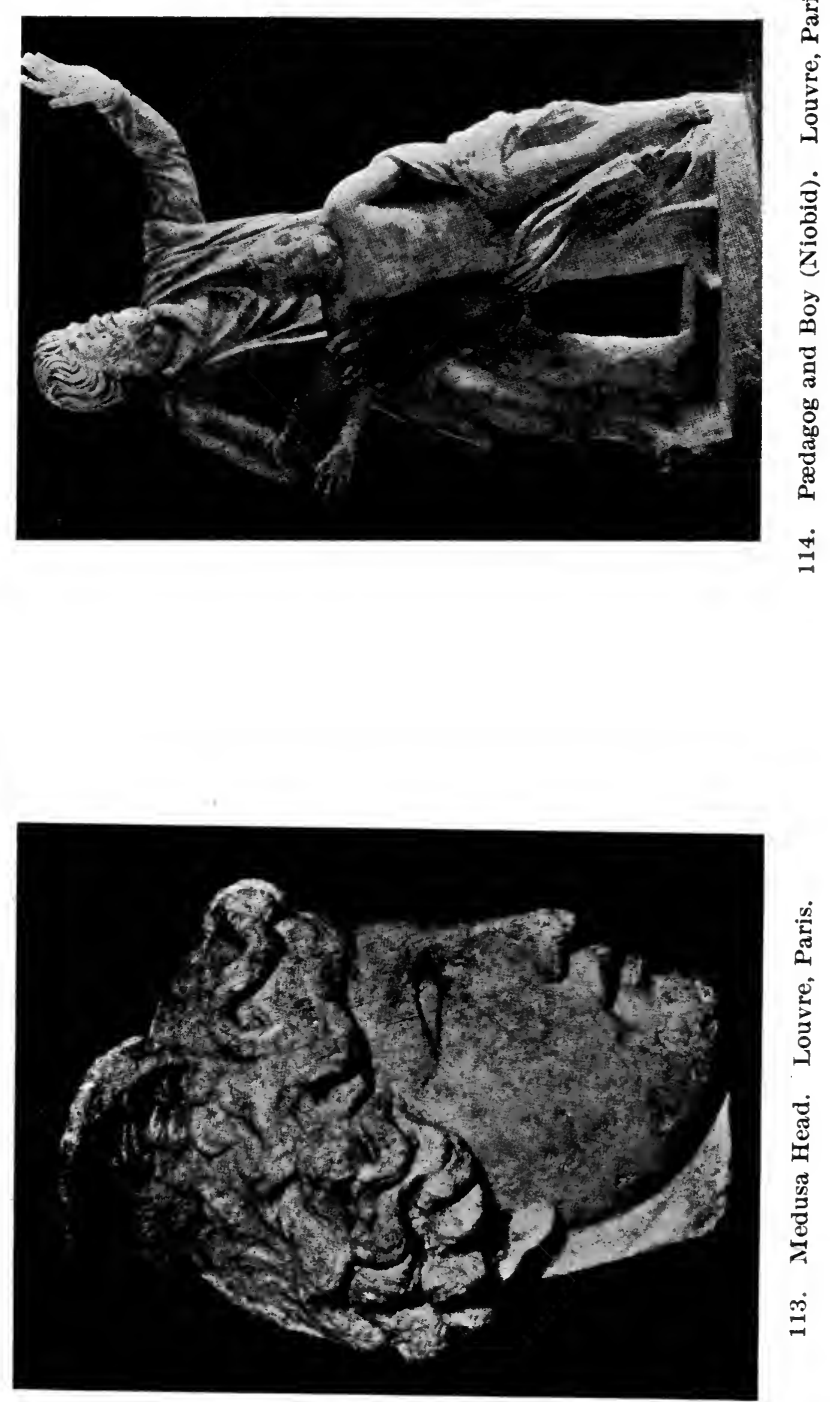

: 

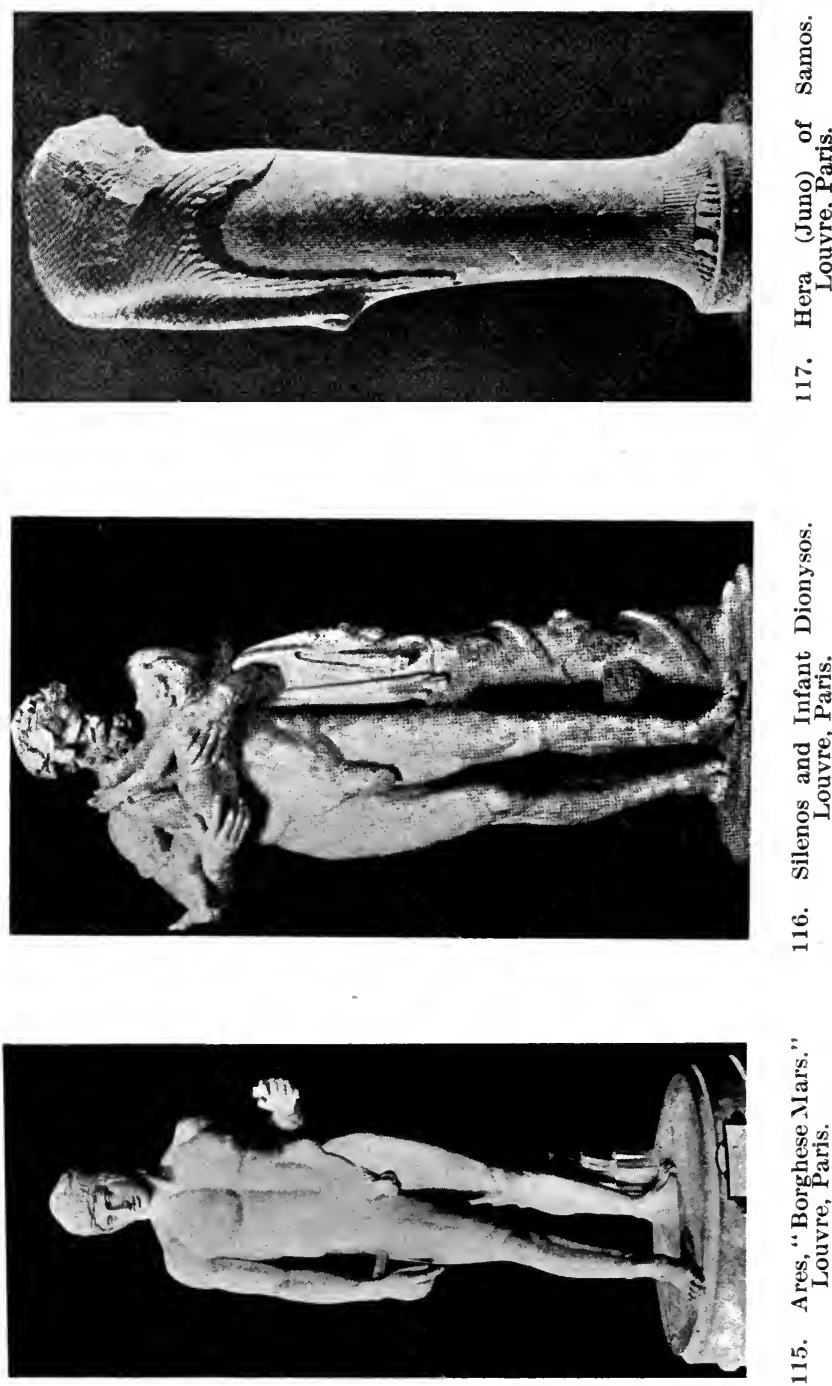


\section{PARIS}

is so beautiful that we are not surprised that it was long considered an original. Not until 1877 , when the group of "Hermes and the Infant Dionysos" was uncovered at Olympia, was it possible to know what an original by Praxiteles meant. Pausanias mentions the Hermes in speaking of the temple of Hera. He says, "Later they dedicated there some other things, also a Hermes of stone carrying the young Dionysos; it was made by Praxiteles." The Hermes, though probably an early work of the master, has given a standard by which to compare works attributed to Praxiteles, and so far no statue, fragmentary or otherwise, has come up to the standard. And yet how satisfying this fragment is! So restful in its attitude of repose. Whoever transferred the spritely creature of the bronze original into the more obdurate marble copy must have caught something of the thought and spirit that the master put into his work. This copyist, as also the copyist of the Capitol's Satyr, has wisely omitted the tail from the leopard skin slung over the satyr's shoulder. The Vatican copy has preserved the tail, but its necessary attachment to the marble body detracts from its real significance.

We will now return to the "Nike" stairway and on the right see a "Head of Medusa" in profile (Fig. I I3), which is unusual. Compare it with that of the National Gallery, Rome (Fig. 39) and

$$
\text { [ I } 53 \text { ] }
$$




\section{WHAT SCULPTURE TO SEE}

note the coarse almost masculine character of the face. This is a woman of years-the elongated profile, the firm set lower jaw and the accentuated chin bespeak a struggle for life of the mature woman, yet the swollen eyelids mark the eternal feminine. The same restraint is shown in portraying the snaky locks that characterised the master of the Medusa of the National Gallery, yet the workmanship falls short. This, however, may in part be due to the coarser grain of the stone.

On the left of the stairway is "The Pædagog and Boy" (Fig. I I4), another part of the Niobe group of Florence. This was found in an ancient Roman settlement at Soissons, France. In comparing this group with the "Pædagog" of Florence (Fig. 55), we feel how incomplete the teacher was without his pupil. Sophocles, in his "Electra," has pictured in words what the sculptor shows us in marble-the beautiful relationship in high-born Greek families between the faithful pedagogue or slave and his young charge. The tender solicitude of the slave is beautifully shown in the caress of his right hand (the right arm and hand are antique) on the boy's outstretched arm. The frightened boy, a mere child, is quieted; and why not? his protector has the strength of one used to making the rough places smooth for his young charge.

In the "Borghese Ares" (Mars) (Fig. I I 5), we have another statue after Alcamenes, the rival 


\section{PARIS}

of the great Pheidias. Though he portrays the god standing in pensive mood, yet his powerful proportions designate him at once as born for war. Ares was the son of Zeus and Hera (Jupiter and Juno). When the Trojan war broke out, Ares, at the wish of Aphrodite, favored the Trojans. It is not surprising that this statue has often been called Achilles, for that Grecian hero was the human counterpart of Ares in his prowess in war, when once drawn into the fray. We know that a statue by Alcamenes once stood in the temple of Mars in Athens.

In the copy after Praxiteles of "Silenos and the Infant Dionysos" of the Louvre (Fig. II6), we get more of the real spirit of love which that master breathed into his works than in the other copies of this group. It is a beautiful thought spoken of this sculptor that "whenever Praxiteles put his chisel to the stone the little god of love was peeping over his shoulder." Could any expression of face speak greater love for a real baby than beams from the face of Silenos on the little Dionysos! Look at the eyes of the foster-father; they fairly glow with the living fire of love, unselfish love. It was into the eyes, the windows of the soul, that Praxiteles put the full measure of his marvellous genius. The eyes of the dreaming Hermes of Olympia beam with love pure and undefiled, yet human and caressing. And also in the 


\section{WHAT SCULPTURE TO SEE}

eyes of Silenos the copyist has gathered the full force of the god's devotion to his foster-child. The baby, too, in this copy, has that soft, clinging caress of babyhood. We can almost hear the little god's bubbling laugh and contented coo. Comparing the Louvre group with the one in Munich (Fig. 92), we are conscious of the greater depth of feeling and of freer rendering of the human baby. The Louvre copyist has attained nearer to the compelling power of the great Praxiteles.

Yes, it is a long, long step backward from the wonderfully human art of Praxiteles to the art of the sculptor who made the "Hera (Juno) of Samos" (Fig. II7). We will now return to the Rotunde and enter the Salle Grecque and find "Hera" in the centre of the room. The early motive in Greek art, as in other countries, was religion; and, believing as the Greeks did that their gods embodied the varied powers of nature, they naturally longed for them to assume some visible form, and who but an artist could create that form. At first, unhewn stones, said to have fallen from heaven, and tree-trunks, were used to satisfy that longing. But as time went on they began to drape the crude symbols to represent the human side of their gods. Still they were not satisfied and then artists began to dare to take stones similar to the sacred heaven-sent symbol, and with hammer and chisel, hew out draped figures. Of course these

$$
\text { [ } 156 \text { ] }
$$



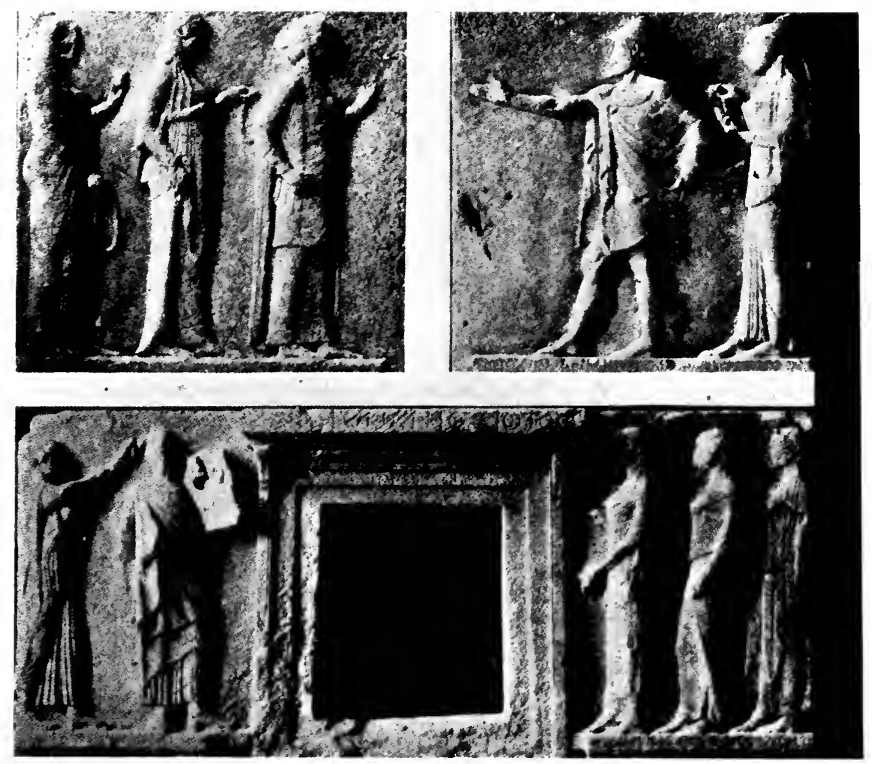

118. Relief from Thasos. Louvre, Paris.

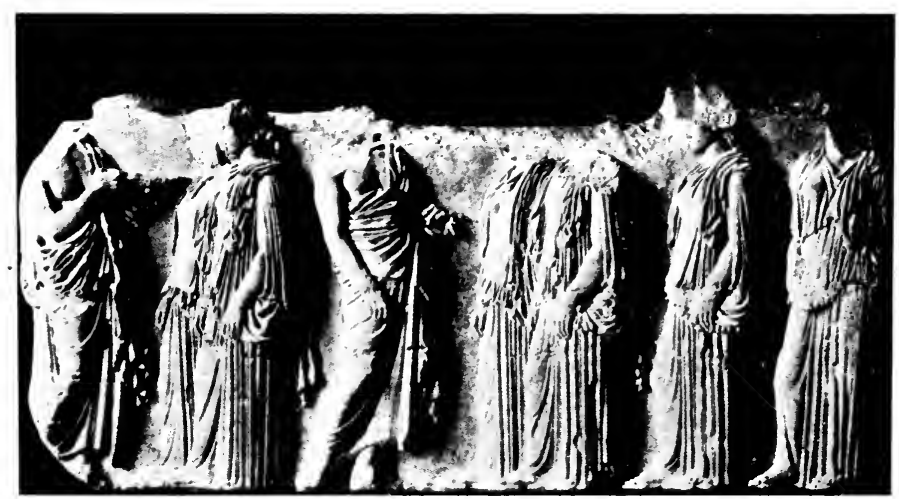

119. Maidens from Fast Frieze of Parthenon. Louvre, Paris. 



\section{PARIS}

were very crude, but quaint and naïve as the work was it represented to them a very human deity.

Now look at the goddess Hera of the Louvre. An inscription carved on the border of her second mantle at the belt says, "Xerameus consecrated me a votive gift to Hera." The date would be about 600 B. C., but not later. The tree-trunk idea has been preserved, yet a complete figure has been evolved from it. Note the toes projecting from beneath the simulated garment. How perfectly the shape of the hidden foot is indicated; the long middle toe shows that the sculptor was a close student of nature. There is great ingenuity in rendering the drapery-four garments can be distinguished. The close bound arms have considerable shapeliness, though bound within proscribed limits. As an example of the beginnings of Greek art, "Hera" is most interesting.

We will now look at the "Relief from Thasos" (Fig. II 8) standing near "Hera," and see the freedom of movement of the figures-they could walk away, which Hera could not do for more reasons than her narrow skirt. Hermes, in the Relief, is easily recognised by his costume-the light chalmis which falls so limply over his arm. His extended right arm and hand can easily move, and his slender neck supports his head with real ease of bearing. The figure of the Grace following Hermes is charming. Her delicately rounded chin

$$
\text { [ } 157 \text { ] }
$$




\section{WHAT SCULPTURE TO SEE}

and the curve of the cheek toward the shapely ear and down the lovely neck is sweet and girlish. Very daintily the two braids of hair cling to the soft flesh, even if they do over-emphasize the full bust.

These slabs were made the first of the fifth century, before the Persian wars, and were probably designed for the entrance of a sacred cavethere are two inscriptions of early characters on the slabs that refer to sacrificial rites. The Thasos Reliefs were made more than a century before the Parthenon marbles, yet the sculptor is breaking away from the old and in many particulars anticipates what was perfected by Pheidias. See how he has brought about the play of light and shade on Hermes in the relief by varying the depth of the background, a technique unthought of before.

Now raise your eyes to the "Maidens from the Frieze of the Parthenon" (Fig. I I9), just above the Thasos relief, and note how the Parthenon sculptors have completed what was begun in the treatment of Hermes. They have also solved other problems of relief sculpture. This group of maidens is but a wee bit from the long procession pictured on the frieze, reproduced in the British Museum (see page 184 ), yet they are complete as a work of art. Quiet and unobtrusive, they fill the space with the personalities of young maidens. They are real young women moving toward the seated gods with a definite purpose.

$$
\text { [ } 158 \text { ] }
$$




\section{PARIS}

The sculptor has not only used the varying depth of background to bring out the light and shade, but the figures and folds of the drapery play upon each other until high lights and shadows come and go as in real life, and yet master-like he has hidden the means by which he produced his effects. These three examples in this room are definite points reached by the sculptors of Greece in treating religious statues, from crude beginnings to the perfected religious procession of the Parthenon Frieze. 


\section{CHAPTER XVII}

\section{PARIS-LOUVRE (Concluded)}

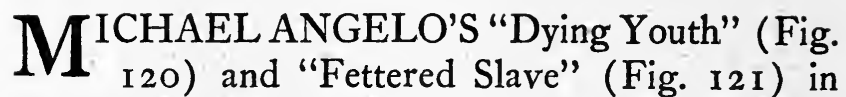
the Salle de Michel-Ange, in the Louvre, represent. the highest achievement of the sculptor's art during the Renaissance in Italy. Put them beside the masterpieces of Pheidias and see how, after two thousand years, sculpture has again reached the acme of excellence. If these captives could have been placed among the statues of the Parthenon pediments what would have been the judgment of those old Greeks? Surely Pheidias would have put them in a place of honour. These statues were designed for the Mausoleum of Pope Julius II along with "Moses" (Fig. 45), but when the size of that monument was reduced, the captives were found to be too large and Michael Angelo gave them to Roberto Strozzi, who sent them to Francis I of France. The French king gave them to the Constable de Montmorency, who used them to ornament the front of his castle in Ecouen. Later they were brought by Cardinal Richelieu to one of his castles at Poitou; then, fortunately for us, the

$$
\text { [ } 160 \text { ] }
$$



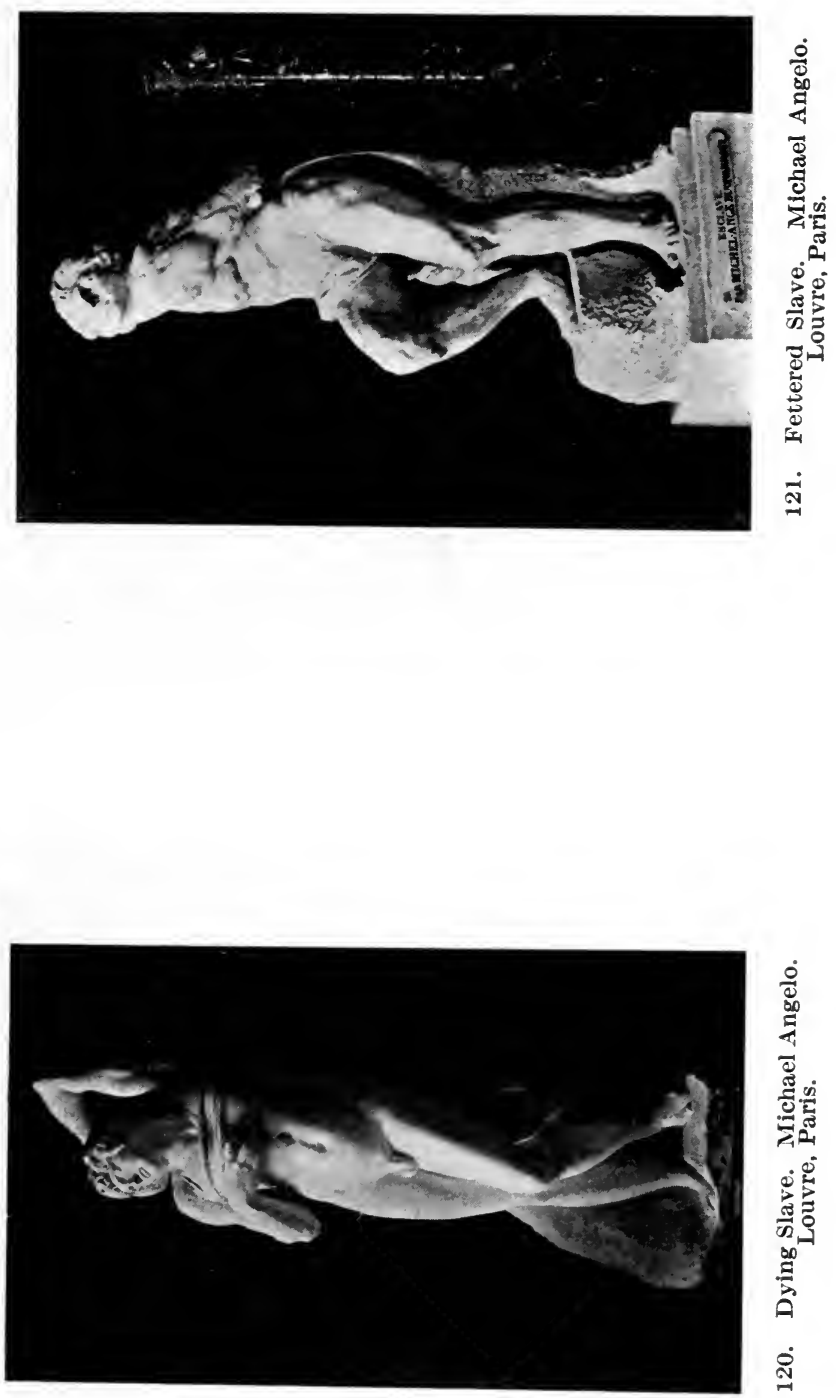

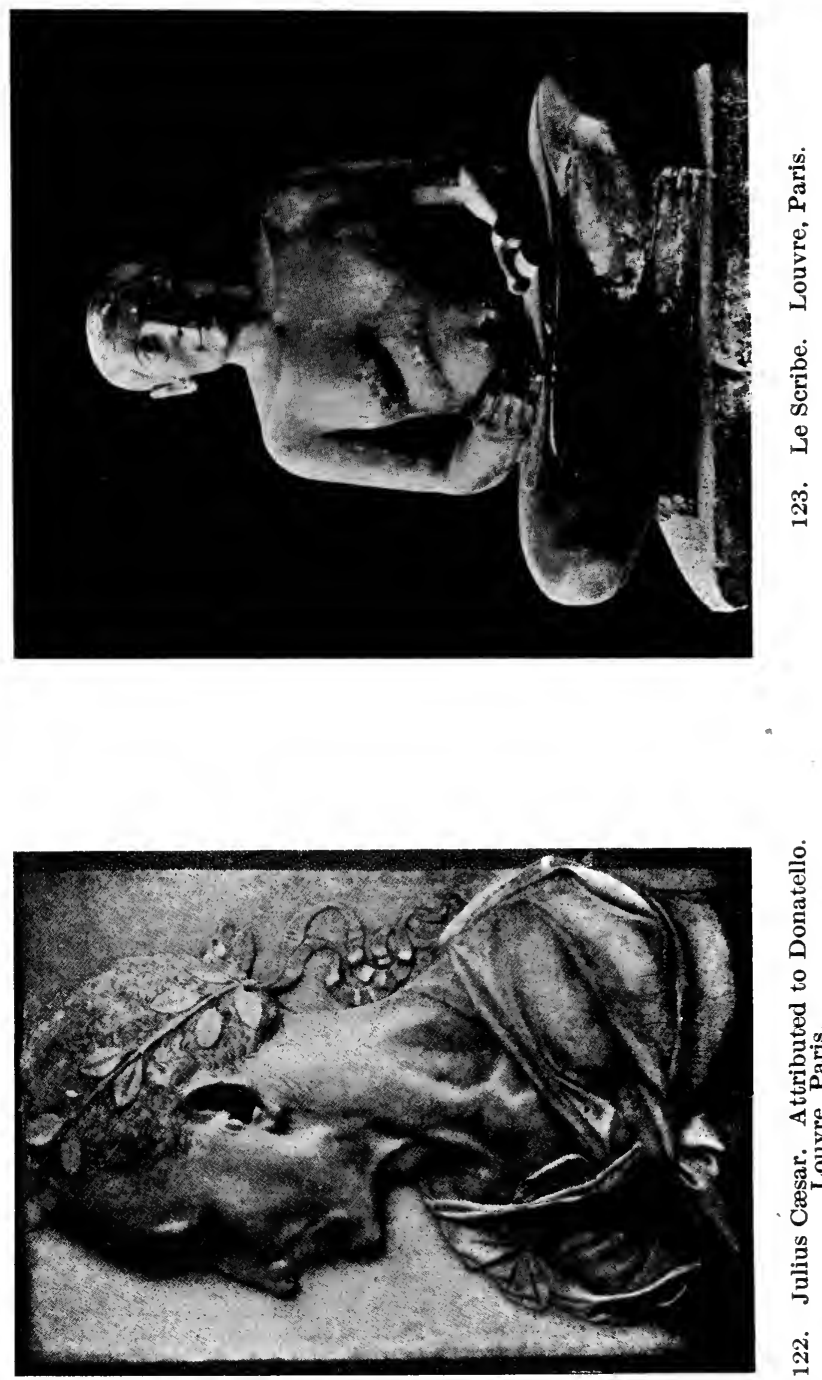


\section{PARIS}

cardinal's sister brought them to Paris. In I 793 they were publicly sold and the Museum of the Louvre bought them.

We feel that in the captives Michael Angelo must have symbolized his own fettered spirit. The limitations put upon him were so galling that when only thirty years old he wrote bitterly to Pope Julius II, "I am your slave, and have been from youth." He was as truly a prisoner under the demands of a pope and prince as though he were chained in a cell. The "Dying Youth" is more correctly called the "Sleeping Youth," and as such the master's lines on "Night," written while he was in the quarries of Carrara, are a fitting tribute to it.

"O night, O sweet though sombre space of time! All things find rest upon their journey's endOur cares thou canst to quietude sublime; For dews and darkness are of peace the friend."

The innocence of youth is portrayed in the tender limbs, pliable flesh and rounded contours of the body, and yet how suggestive of nascent strength is the inert body; whether overcome by death or by sleep the power is still there. The simply told story of suppressed force in the Sleeping Youth is very powerful.

The Fettered Captive, writhing to break the chains that bind him, is so real in his agony that we too feel the strain of his struggles. One won-

$$
\text { [ } 16 \mathrm{I} \text { ] }
$$




\section{WHAT SCULPTURE TO SEE}

ders if the old pope recognized the irony Michael Angelo was putting into these statues, as he watched the sculptor at his work day after day. At least the sparks flew when these two fiery natures clashed - which they did very often-and it was not unusual that Julius was the one who had to sue for peace, or he had no more work from the sculptor.

Though the bas-relief of "Julius Cæsar" (Fig. I22) is only attributed to Donatello, yet it bears many ear-marks of this sculptor. As we study this relief of "Caius Julius Cæsar, Dictator of the Earth," we feel the character of the man whose name is the title of four empires to-day-Cæsar, Kaiser, Czar, Kaisár. And then who could represent character better than Donatello, whose special excellence was to portray character? Donatello also brought the art of bas-relief in single works to a very high state of perfection. Light and shade play on his figures as though they were painted, and so they are-with a steel brush. Note the subtle touch of humour that flits over the face of the emperor; it comes and goes as though a living spirit were in the relief itself. No Greek sculptor was more restrained in giving unnecessary details or in overcrowding a work.

It is not at all incongruous to go from the relief of Julius Cæsar of the fourteenth century A. D. to "Le Scribe" (Fig. I23) of the fifth century 

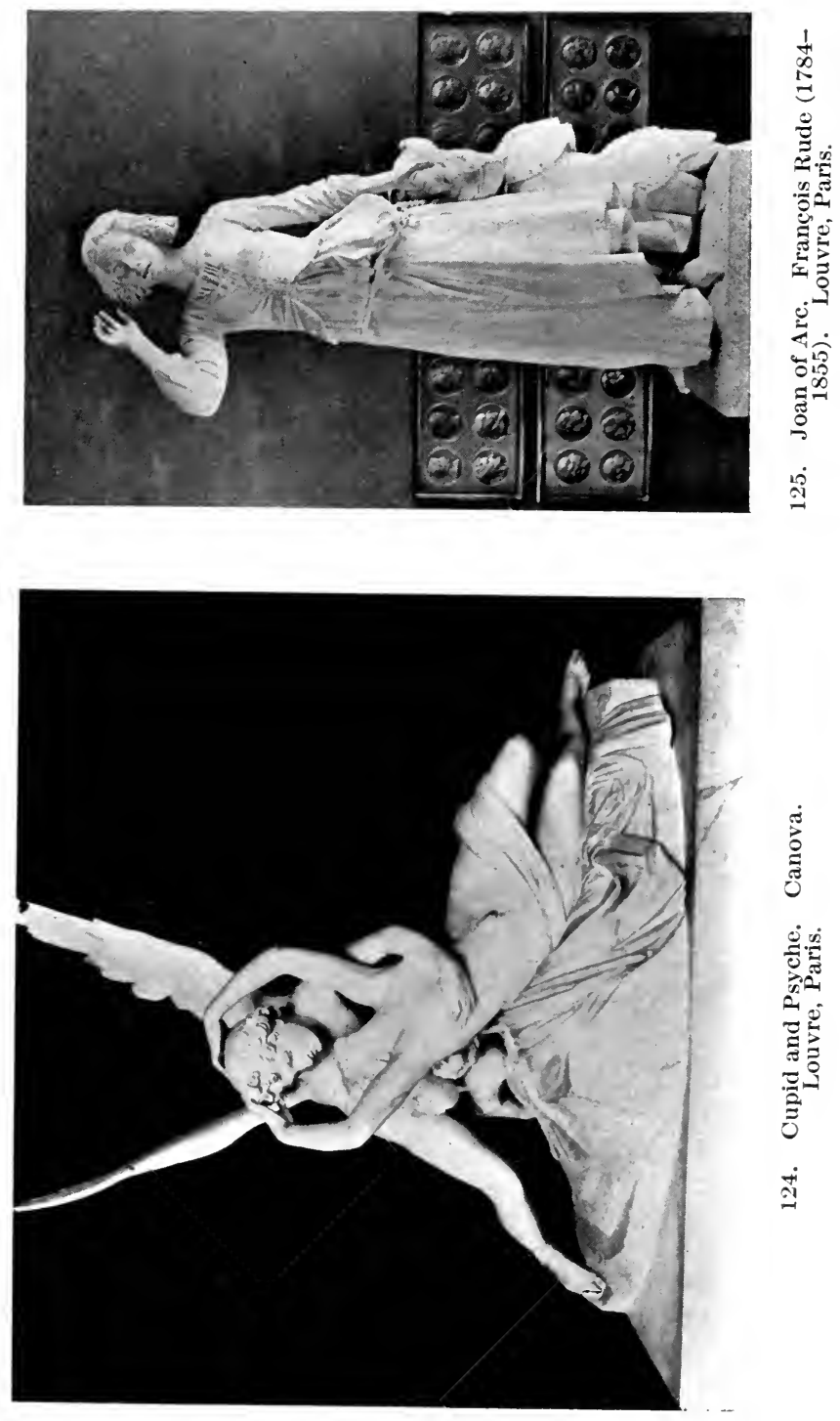

ঠึ

$\stackrel{\dot{0}}{0}$

ค.

롫

들

כ)

iี 


\section{PARIS}

B. C., for both portraits represent men of character, and both sculptors were masters in their art. This Egyptian scribe sitting cross-legged in the centre of the Salle Civile, in the Louvre, is one of the best bits of the ancient art of the Nile in existence. As a portrait it combines the personality of the individual and the universal characteristics of a class. Like Moroni's "Tailor," in the National Gallery, London (see "What Pictures to See in Europe," page 156 ), he is a man. It matters little what his name is; he is of value. He serves faithfully, but his silence is of respect, not servility. $\mathrm{He}$ is more than a specialist, this stenographer. His breadth of chest, high shoulders and well poised head are proof that he is a man of affairs.

One of the daintiest groups of modern sculpture is Canova's "Cupid and Psyche" (Fig. I24), in the west portion of the Vieux Louvre. The invasion of the French, so disastrous to the art works of Italy at the dawn of the nineteenth century, was Canova's opportunity. It was then that he made his "Perseus," a statue so like the Apollo Belvedere (Fig. I2) in pose and graceful beauty that it was not only secured for the Vatican gallery, but took the place of the Apollo, while the latter went to Paris with Napoleon. At that time also, he made his Venus to replace the Venus de' Medici (Fig. 56), while it too visited the French capital. The French nation proved her greatness when, after the 


\section{WHAT SCULPTURE TO SEE}

sanity of peace came, she returned all the masterpieces taken from Italy as spoils of war.

Canova's group of "Cupid and Psyche" has several replicas and numerous miniature reproductions. Tenderly and delicately Canova has wrought out the maiden Psyche and the god of love. Cupid's kiss is as gentle as the falling moonbeam, and his caress as tender as the zephyr. We stand abashed as though a veil had been lifted from a sacred shrine.

No young girl in all history has been more often represented in painting or sculpture than Joan of Arc. It is now nearly five hundred years since St. Michael appeared to this peasant girl in her father's garden at Domrémy, France, yet her visions are the visions the artist sees as he paints her with brush and chisel. François Rude's "Joan of Arc" (Fig. 125) stands listening to the prophetic words of St. Michael. "Joan," he is saying, "you are called for marvellous things-dress yourself in armour. You shall lead in war, and all shall be done as you advise." As if to emphasise the reality of her vision, Rude has placed a suit of mail at her side and encased her left foot in steel armour. Joan never holds us by any beauty of face or form, but by her visions.

Very simple and girlish is "Joan of Arc" (Fig. I 26), as Henri Chapu represents her seated on her feet with her hands clasped and her face raised to

$$
\text { [ } 164 \text { ] }
$$




\section{PARIS}

the vision that reveals her future. Her eyes see beyond the veil; her destiny is fixed; her life is to fulfil a mission. She is dignified and reposeful, though her attitude is tense and full of the ardour of an earnest purpose. This statue, possibly the greatest of Chapu's, was exhibited in the Salon of 1870 .

France was in a deplorable state while Joan of Arc, in the little town of Domrémy, was passing her childhood dreaming dreams and seeing visions for the rescue of her beloved country. Charles VI, who, in 1392, was marching against the Duke of Brittany, became suddenly demented from a shock given by a maniac who stopped his horse and cried, "Do not proceed farther, noble king: you are betrayed." The kingdom was now torn asunder by internal strife between the Orleanists and the Burgundians, and then, to add to the disaffected state, the English king Henry $\mathrm{V}$ landed in Normandy and was victorious over the French at Agincourt, 1415. Pillage, murder, fighting, and bloodshed and the death of the mad but beloved king, Charles VI, in 1422, put most of France in the power of the English. The real French heir to the throne, Charles of Valois, was poor and powerless, with but a few supporters in central and southern France, while Henry VI of England was crowned king at St. Denis. It was at this juncture that Joan of Arc, the Maid of Orleans, came to the rescue and saved

$$
\text { [ } 165]
$$




\section{WHAT SCULPTURE TO SEE}

the nation. Poor Joan, only a child in her early teens, died a martyr. Her trial was shameful and inhuman-a fearful disgrace to England who directed it, and to France who furnished the fiend, Bishop Beauvais, to conduct the trial. At last, in 1908, France has acknowledged her debt of gratitude and has placed the noble peasant girl among the saints in the French calendar.

Stop a moment and look at Houdon's bust of Voltaire. Rodin says: "It is the personification of malice. See the sidelong glance that seems to watch for some adversary. He has the pointed nose of the fox. He seems to smell out abuse and ridicule on every side-you can fairly see it quiver. And the mouth! What a triumph!-A cunning old gossip-that is the impression produced by this Voltaire at once so lively, so sickly and so unmasculine."

The "Centaur and the Lapith" (Fig. I 27), by Barye, is one of several groups where this sculptor has shown his accurate knowledge of comparative anatomy. Until Barye came with his vitalising chisel, no sculptor ever even approached the old Greeks in representing these chimerical beings of mythology. The ancient Greeks made companions of the Centaurs, and when Pirithous and Hippodomia were married, these half-human creatures were invited io the wedding. But unfortunately, Eurython, one of the Centaurs, drank too freely

$$
\text { [ I66] }
$$




\section{PARIS}

of the wine and overstepped the bounds of propriety toward the bride. This angered the men, and then broke out the famous battle of the Lapithæ and the Centaurs. A full account of the battle is pictured on the metopes of the Parthenon (see Fig. I43).

Barye's portrayal of power in the onrush of this half-human monster is only equalled by the marvellous strength of the arresting arm of the Lapith. The sculptor has made us feel that the true home of these half-brute, half-human creatures was in the free air of the woods and the fields, and that when the liberty of human companionship was given them, their wild nature took it as license. Note the combination of man-body and horse-body and see how the muscles of the neck and back have coalesced into a trunk that the Lapith easily bends back to his knee. Look at the stretch of the skin over the ribs in both antagonists and note the same freedom in the use of the arms in both. We think very little of the uncanny union of horse and man in this monster because our interest centres on the strange conflict. The brute force of that shapely body is tremendous, yet the weakness of the spirit in the upturned face shows plainly that the Centaur has met his master. One blow of the club in the raised hand of the Lapith will still the monster forever.

Barye was a realist in the true sense of the word.

$$
\text { [ } 167 \text { ] }
$$




\section{WHAT SCULPTURE TO SEE}

Let us now stand before his lions and we will say with Alfred de Musset, "What vigour and what truth! Where indeed has he found a way of making such models pose? Is his atélier a desert of Africa or a forest of Hindustan ?" 

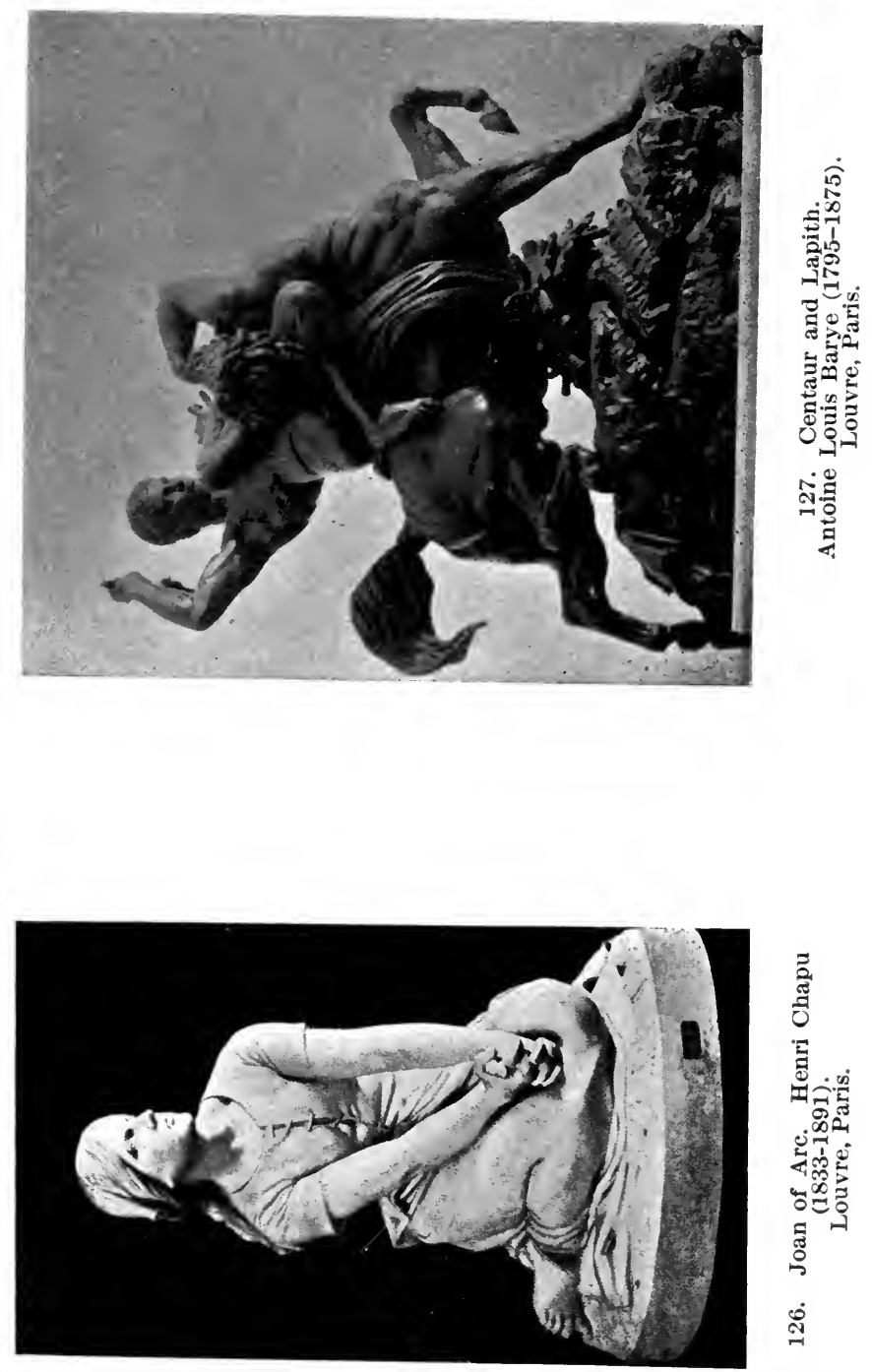

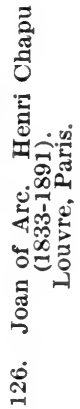




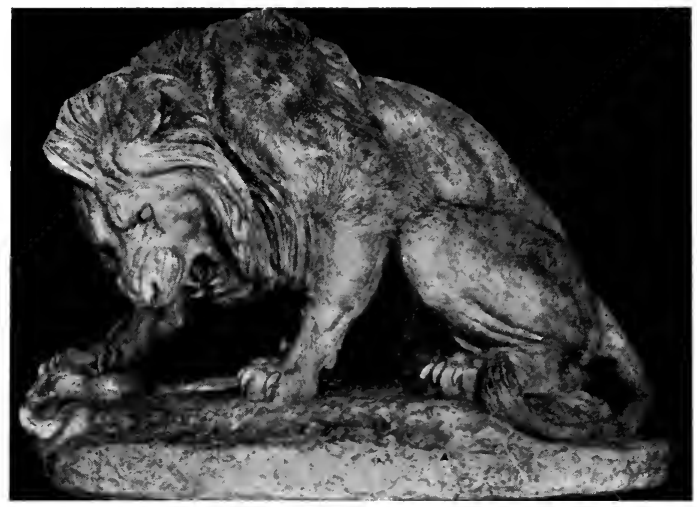

128. The Lion and the Serpent. Antoine Louis Barye. The Tuileries Gardens, Paris.

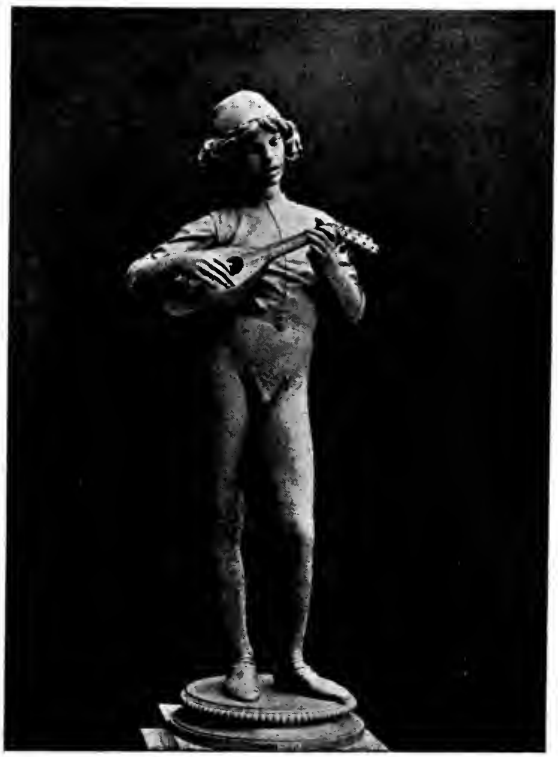

129. Florentine Singer. Paul Dubois (1829-?). Luxembourg, Paris. 


\section{CHAPTER XVIII \\ PARIS-MISCELLANEOUS}

A NTOINE BARYE was at his best in his aniA mals, and of these animals the lion most nearly represents the man himself, a man of "lofty, isolated strength." As we leave the Louvre facing the Seine, his colossal bronze "Seated Lion" is beside us in all its lofty isolated strength. When Barye had finished this superb beast the French authorities asked for a balancing figure. Barye, not willing to cheapen his masterpiece by duplication, submitted, at a very high figure, a companionpiece. This they refused because of lack of funds, they said, and had a reversed lion cast for the place-a cruel hurt to the master. What are the few thousand francs to-day, we ask, compared with the loss of a masterpiece by Barye? We now know how true a prophet this master was, when in answer to his wife's remark during his last illness, as she dusted the bronzes standing around, "My dear, when you are better, see that the signatures are more legible."

"Never fear," replied Barye, "before twenty years have passed, people will be using a magnifying glass to my signatures." And they were.

$$
\text { [ } 169 \text { ] }
$$




\section{WHAT SCULPTURE TO SEE}

When the cast of Barye's "Lion Crushing a Serpent" (Fig. I28), that now stands in the Tuileries Gardens, was exhibited at the Salon of 1833 , it must have startled the rule-by-thumb Academicians and their studio-made lions. Théophile very amusingly writes, "At the sight of Barye's superb and terrible beast bristling his unkempt mane, wrinkling his muzzle with a rage mingled with disgust above the hideous reptile which, pinned under his claws, writhes in convulsions of impotent rage, all these poor old marble lions must have whipped their tails between their legs, and in astonishment nearly let go the ball which served to keep them in countenance." Another writer of the time says of the startling innovation, "It seemed to me at first the lion moved; yesterday I heard it roar." Wait a moment; I think that we too may hear it roar! When the state bought the group and placed it in the public gardens we are not surprised that one critic exclaimed, "Since when were the Tuileries a menagerie?" One of the strange contradictions of Barye's work is that, whether colossal or diminutive, the spirit of grandeur is the same. The fact that the blindness of the French critics compelled him to manufacture paper-weights for a living did not lessen his painstaking care in each article, every one of which he signed with his own hand. Many a humble home has been the gainer in possessing one of these treas-

$$
\text { [ } 170 \text { ] }
$$




\section{PARIS}

ures, yet what a loss to the world that that power could not have been put into monumental masterpieces.

In the Luxembourg is Paul Dubois' "Florentine Singer" (Fig. I29), a statue that brought the sculptor immediate fame. In this thoughtful youth is combined the soul of music and the spirit of song. Every line of his body pulsates with the rhythm that flows from his parted lips. The song comes as spontaneously through the boy's open mouth as his breath. The strings of his instrument respond to his delicate touch simply as a gentle reminder that all things are atune to the song in his heart. Though perfectly simple in composition, yet this peasant boy stirs us curiously. Again and again we look up into those downcast eyes and listen to the melody that comes from those silent lips. There is something fascinating in the unkempt hair and the slender boyish figure. Sing on, my guileless boy, may you ever keep the music of purity that is now your birthright.

Dubois was a leader in French art in the middle of the last century. In him is united the intense fervour of Donatello and the love of balanced order, the latter never overstepping the laws of decorum, yet always free and unfettered in expression. The time had come in France when the severely classical no longer held sway. Not Barye alone saw animals as living creatures but all artists,

$$
\text { [ I 7 I ] }
$$




\section{WHAT SCULPTURE TO SEE}

even the most conservative, were observing nature with seeing eyes. A French Renaissance was at hand and Paul Dubois became a brilliant director of the Ecole des Beaux-Arts and a leader of the younger French students. His "Narcissus," also in the Luxembourg, expresses the new spirit of the Renaissance.

Saint Marceaux' "Genius Guarding the Secret of the Tomb," in the Luxembourg (Fig. r30), reminds us of Michael Angelo. The strain of the muscles in the unnatural twist of the body is quite like that of the great master, yet how weak is the cause of the strain in Marceaux' work compared with that in the "Fettered Slave" (Fig. I2 I). Perhaps if the figure of "Genius" were part of a group to be viewed from a distance above us, the unpleasant striving-for-effect impression would disappear, and then the strength of the nude body would captivate us.

In "St. John the Baptist," in the Luxembourg, (Fig. I3I), Auguste Rodin illustrates his own belief that "that which is considered ugly in Nature often presents more character than that which is called beautiful-" and further on he writes, "and as it is solely the power of character which makes for beauty in Art, it often happens that the uglier a being is in Nature, the more beautiful in Art." Now as we look at this half-starved preacher we do see that his power over us is because an inner 

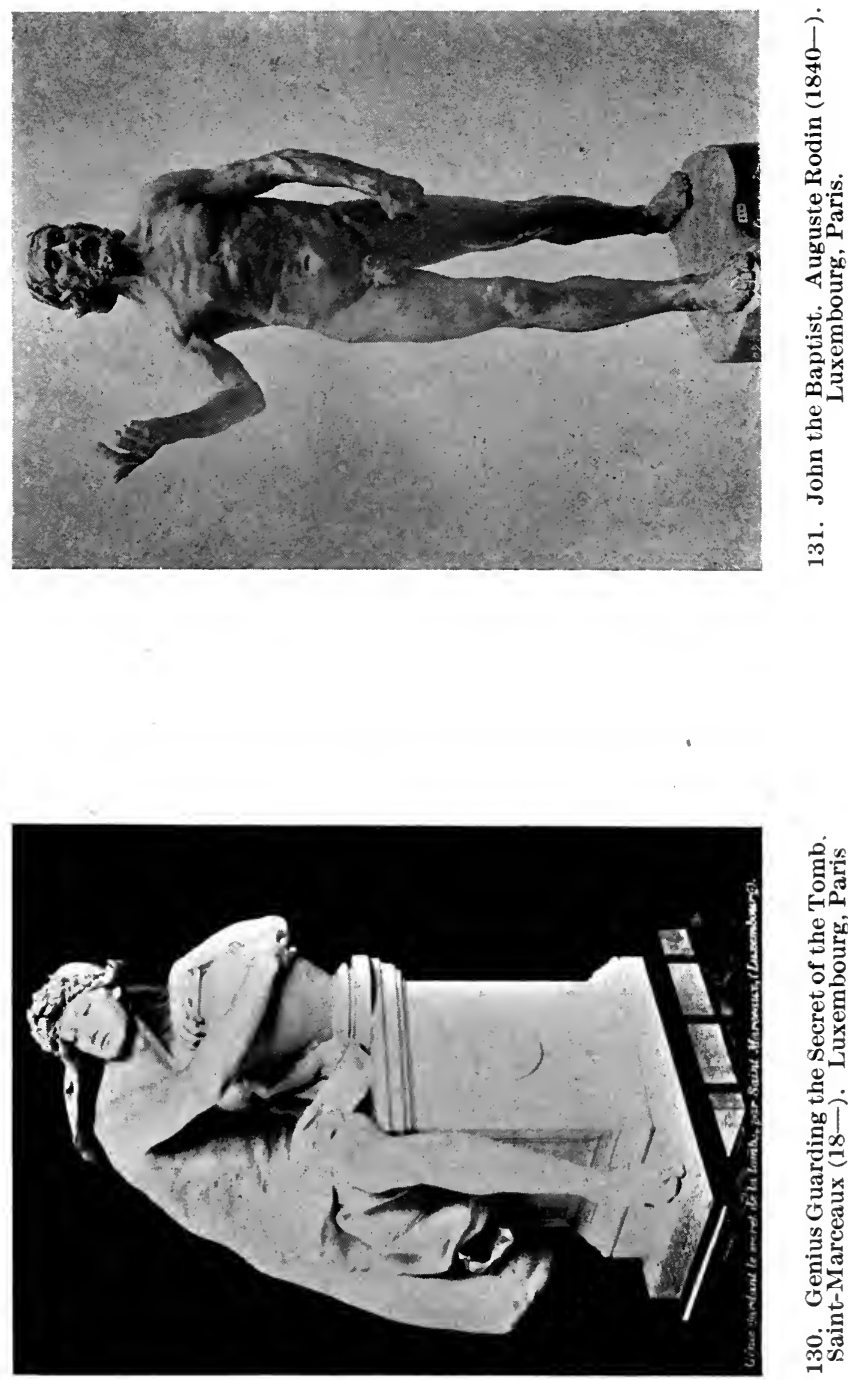

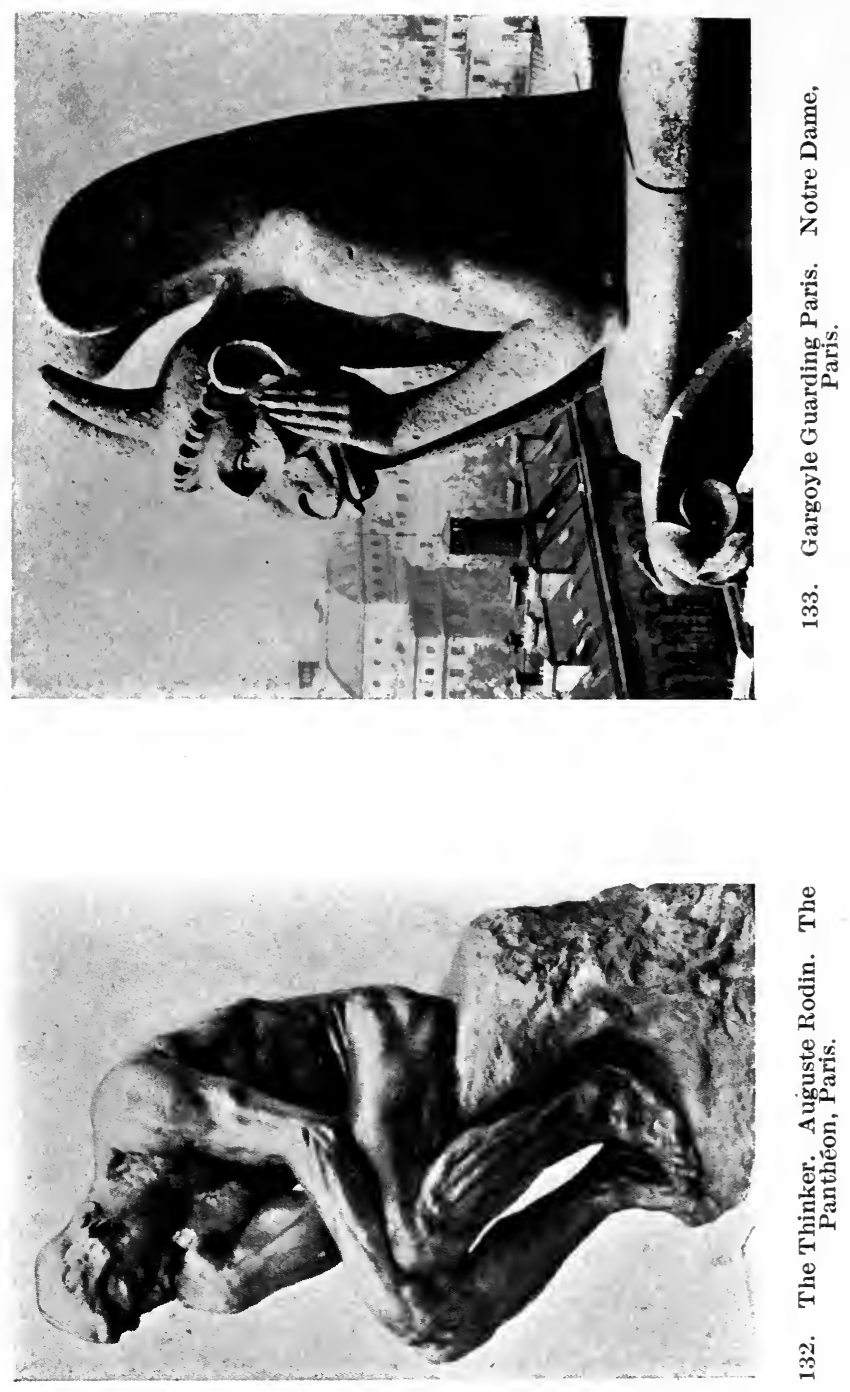


\section{PARIS}

truth shines forth in his every word. The gaunt, emaciated body speaks only of an exalted spirit that carries conviction to each soul.

But what words can possibly do justice to the tremendous genius of Rodin, the "Shakespeare in Stone?"? Instead of genius meaning madness as some assert, Rodin himself says, "But men of genius are just those who by their trade-skill carry the essential thing to perfection." And that is just it; Rodin seeks the essential, the distinguishing mark in person or thing and centres all his thought around that until a full character is developed.

For twenty years Rodin has been working on the famous "Door of Hell," of the Museum of Decorative Arts. He began the work with Dante's "Inferno" as a suggestive plan, and to-day the two "Infernos," Dante's and Rodin's, stand as the two great masterpieces in word pictures and bronze pictures of all time. The solitary figure, "The Thinker" (Fig. 132), in front of the Pantheon, Paris, is Dante brooding over the awful visions his own brain conjured and Rodin has made visible. In "The Thinker" is expressed power, to create a vision of eternal damnation, and knowledge, that the efforts of the condemned for release are futile. Above the portal through which they came is written, "Abandon hope all ye who enter here!" and the brooding figure emphasizes their doom.

We will now visit the "Ancient Queen of Ca- 


\section{WHAT SCULPTURE TO SEE}

thedrals," as Victor Hugo calls Notre Dame, and look at those strange, ugly, grotesque creatures that guard that sacred edifice. At projecting corner and secret angle they peer down at us, or, ignoring our existence, gaze out on the vast city with its multitude of people moving far below. They are neither brute nor animal, these gargoyles, yet in them is found pictured every attribute of the human soul. Even if pure animal in form, they express an uncanny understanding of human frailties. No one knows the names of the artists who evolved the curious genie, yet nearly a millennium ago they crowded nook and crevice, pinnacle and point of Notre Dame with their creations. That some of them carry off the waste water of the vast roof is true, but that more of them are grinning, sneering, scowling, scoffing, laughing, and poking all sorts of fun at us is equally true. It is well worth a trip to the roof of Notre Dame just to get close to these monsters of superhuman intelligence. You will find that each individual creature is carefully and artistically finished and that of the multitude of figures no two are alike. Look at Biscornette himself (Fig. I33) ; how wonderfully detailed yet how broad in conception! The old legend that gave to Biscornette the power of bestowing unsurpassed skill if the artist would deed his soul to the fiend, is portrayed in this figure leaning on the parapet with his leering face sunk in his claw-like 


\section{PARIS}

hands. These grotesque beings grip us like a vise; we feel with Victor Hugo's gossips that "eyes and mouths open here and there; the dogs, and the dragons, and the griffins of stone which keep watch night and day with outstretched neck and open jaws, around the cathedral," are really heard to bark and howl, yet how artistic they are in their ugliness! The harmony of line and symmetry in decoration is simply perfect in variety and interest.

We should probably regret if we left Paris without seeing the statue of "Athena Medici" (Fig. I34), in the Ecole des Beaux-Arts. This statue, of all existing ones of Athena, will give us the best idea of the Greek conception of the goddess of wisdom. She is every inch a woman of power, of dignity, of poise, as she stands before us. The grand and simple lines that form the quiet, restful attitude of this goddess carved from Pentalic marble mark her as belonging to the Pheidian age in spirit, though some claim that she is a Roman copy of a Greek work. At one time this statue belonged to the Medici collection, which gave it the name "Athena Medici."

The one work of really artistic merit to see in the Père-Lachaise Cemetery, is Albert Bartolome's "Monument des Morts" (Fig. 135). The sculptor has preserved the general plan of the "Relief of Thasos" (Fig. I I 8), but in his own individual style. Could anything express aloneness

$$
\text { [ } 175 \text { ] }
$$




\section{WHAT SCULPTURE TO SEE}

more vividly than the two figures at the door of the tomb? The woman, with true womanly instinct, stretches an appealing hand to her life-long companion, yet her face is set toward the unknown. She is unafraid, only she wants to feel the companionship of her mate until the moment of going forth alone. He stands alone, yet would his attitude of strength be complete without the woman near him? Compare the approaching figures on either side of the open doorway. At the right, while they hesitate and even look back, there is no terror to them in the thought of death. Not so with those on the left. See how they are pushed forward by some invisible force, terror written on faces and forms. They cringe and agonise as they stumble toward the tomb, but no effort on their part retards their forward movement. This relief, though not pleasing in subject, is tremendous in its significance. Possibly we are the more interested in this group because of the very few works of art at the Père-Lachaise. Its ground is hallowed with the ashes of the great, but its tombs are hideous with tawdry bead work and cheap tinsel decorations. Bartolome's monument in bronze stands as a beginning, we hope, of more memorials worthy the artistic French people. 

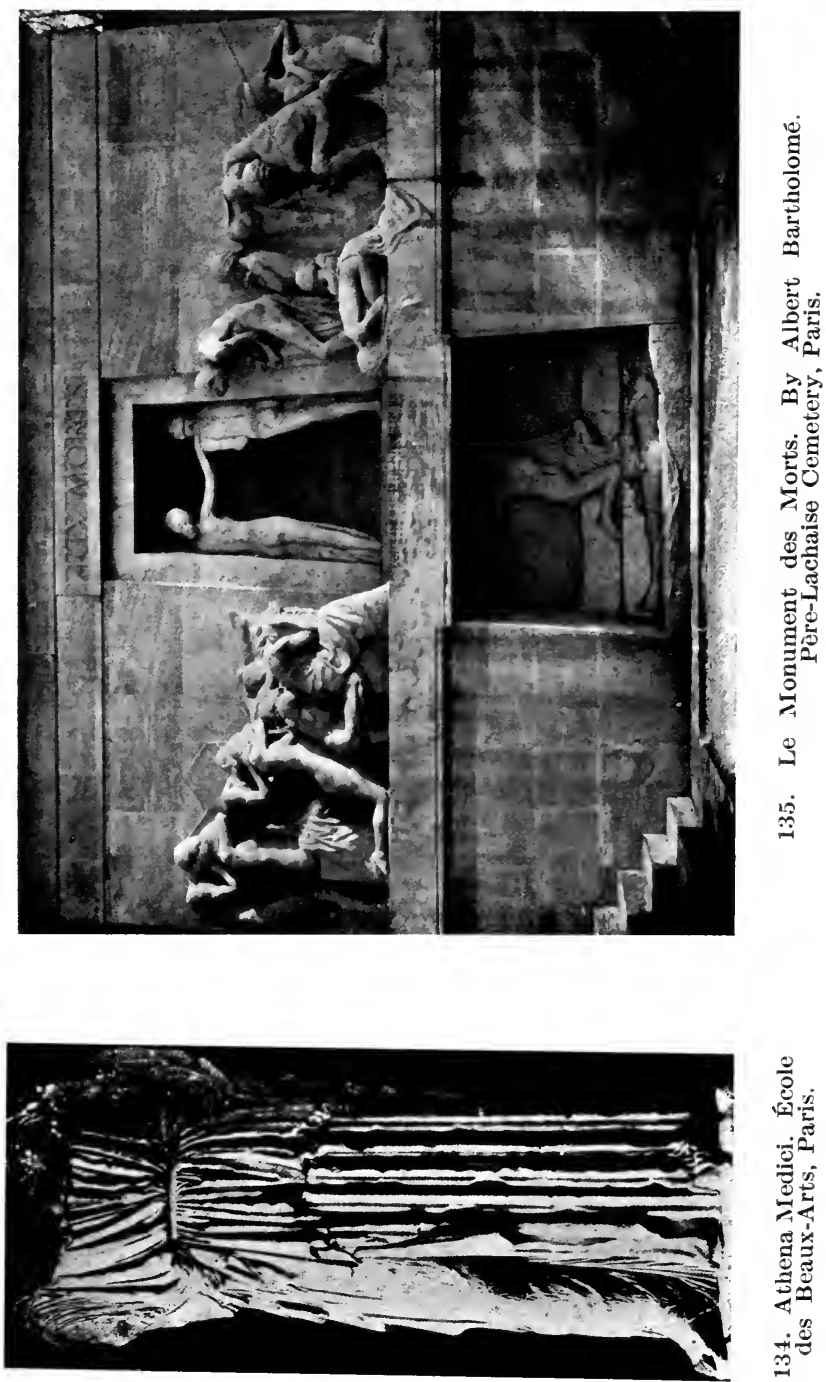

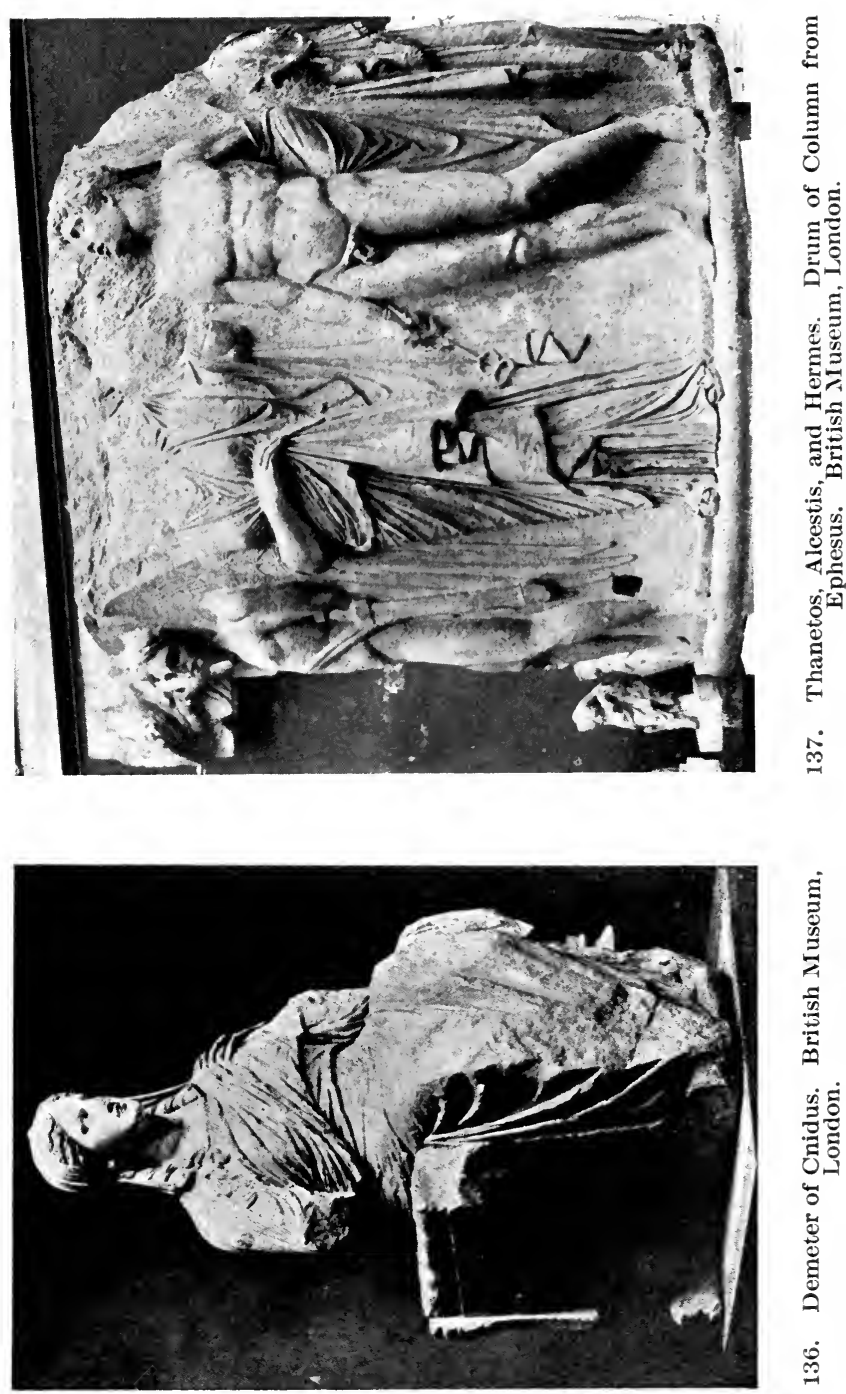


\section{CHAPTER XIX \\ LONDON-BRITISH MUSEUM}

UST the name, "British Museum," is overJ whelming! The vast building, with its hundreds of thousands of treasures, simply paralyses the mind. Usually the general tourist wanders aimlessly, seeing a few things, of course, but comprehending very little. Naturally, we shall confine ourselves to the sculpture, yet here again we are overwhelmed, for the whole world has contributed to this single department. Let us begin then with Greece and go at once to the Parthenon marbles, the treasure of treasures.

But stop; we must see "Demeter of Cnidus" (Fig. 136), sitting here in the entryway! Demeter is the so-called Mater Doloroso of antiquity. You will remember that Demeter, or Ceres, the goddess of agriculture, was the mother of Persephone, the maiden who was compelled to spend six months every year in the lower regions away from her mother (typifying winter). This statue of Demeter was one of many fragmentary works of art found at Cnidus, Asia Minor, in a private shrine on a precipice overhanging the sea. The precious marbles of the temples and shrines of Cnidus 


\section{WHAT SCULPTURE TO SEE}

served for many years as quarries for the Greeks and Turks. Even as late as I838 Mehemet Ali used shiploads of the choice treasures to build his palace. But in I 858 the discoveries of Professor Newton put a stop to such vandalism.

The body of Demeter, of schistous marble, is badly mutilated, but the exquisite head, of Parian marble, is so like the Hermes of Olympia in beauty of workmanship that we feel the touch of Praxiteles. We would gladly associate this tenderly loving mother with the divine Aphrodite (Fig. I3), the centre of attraction at Cnidus. The mingling of grief and hopeful mother-love is so subtle that it is impossible to tell wherein it lies. The eyes have the far-away look of resignation, yet the mouth is all but ready to smile. The sculptor has perfectly balanced the mother's hopelessness in search for her lost child with her thankfulness at Pluto's (Persephone's husband) promise that she should return to her mother half of each year.

Another episode in the story of Persephone is found in "Thanatos, Alcestas and Hermes," on the Drum Column, from Ephesus (Fig. 137) in the room between the anteroom and the Parthenon marbles. The myth is that when Admetos married the beautiful Alcestas the goddess Artemis (Diana) was greatly incensed that she was not invited to the wedding, and in revenge sent snakes to the bridal chamber. Apollo, however,

$$
\text { [ } 178 \text { ] }
$$




\section{LONDON}

interceded with his sister Artemis, and also wrung the promise from the Fates that Admetos need not die if any one was willing to take his place. But unluckily, Alcestas, his beloved bride, insisted that she should be the one to die, and the Fates decreed it should be so. Thanatos (Death) led her away. Persephone (just beyond Hermes on the column), overcome with such self-sacrifice, bids Hermes, the conductor of souls, take Alcestas back to Admetos. On the other side of Alcestas is Thanatos looking sorrowfully disappointed. The treatment of the drapery of Alcestas' garments is considered one of the most wonderful pieces of realism in all sculpture. So soft is the texture of the materiai that the folds held by Alcestas would fall to the floor if her fingers were in the least relaxed. It seems incredible that a substance so obdurate as marble could be made to appear so soft and yielding.

This sculptured drum is part of a column belonging to the temple of the great goddess Diana, one of the seven wonders of the world, that was in its prime when St. Paul was in Ephesus (Acts xix). The original temple on this spot, built as early as the sixth century B. C., was burned in 356 B. C., and was rebuilt by Alexander the Great. Part of a sculptured column of the archaic temple, also in this room, has an inscription that implies that King Crosus dedicated the column, as $\mathrm{He}$ rodotus has stated. 


\section{WHAT SCULPTURE TO SEE}

At last we stand before the Parthenon Marbles! Broken and fragmentary they are, but powerful and compelling. When Pericles appointed Pheidias to superintend the rebuilding of Athens after the Persian invasion, the fifth century B. C., he made it possible for the world to inherit great masterpieces. If Pheidias did not personally carve the statues, he must at least have designed them. The barest outline of the history of the Parthenon from the time Pausanias (second century B. C.) reported, "What one sees on the pediment (gable) as one enters the temple is entirely concerned with the birth of Athena; while at the back is the strife of Poseidon against Athena for the land," until the explosion of the Turkish powder magazine within the temple in the year 1687 , is full of intense interest.

Three centuries after Pausanias wrote, the colossal Athena Parthenos was taken to enrich the circus of Constantinople. In A. D. 435, the temple was first used as a Christian church. Very little change was made externally until the rounded apse was built in 1205, when the central slab of the frieze and probably the central group of the east pediment, containing the birth of Athena, were removed. In 1674, shortly before the explosion, Carrey, a French artist, made a drawing of both pediments. In this drawing not only the central group of the east pediment is missing, but in the

[ I 80 ] 


\section{LONDON}

west one the goddess is scarcely recognizable. A little later the Venetian Morosini decided to take Athena's horses and Poseidon away with him, but while lowering them the tackling broke and the precious treasures fell to the ground, where "they went up into dust."

What was left of the sculptures after the explosion were exposed to the elements and the vandalism of man until the opening of the nineteenth century, when Lord Elgin obtained permission of the Porte to carry them off to England. Fifteen years later, in 1816 , the English government bought them and placed them in the British Museum.

It is still a debatable question just how the birth of Athena was represented on the lost slab of the east pediment. A relief on a well head in Madrid may possibly be the correct picture. In this relief Athena, fully armed, stands in front of seated Zeus. Hephæstos (Vulcan), back of Zeus, starts away as if affrighted at the result of the blow he has dealt the head of Zeus with his lifted hammer (see page 33). At least this representation is more fitting for the monumental character of the marbles of the Parthenon than the one commonly pictured on the old Attic vases. That picture shows Athena, a pigmy goddess, springing directly from the head of Zeus and floating away like an inflated doll. Certainly to have Athena as the pivotal figure un-

$$
\text { [ I 8 I ] }
$$




\section{WHAT SCULPTURE TO SEE}

der the apex of the pediment would seem more appropriate.

Probably the most widely known of all the Parthenon statues is the group of the so-called "Three Fates" (Fig. I38). No matter whether the figures are the fates or personify the home, the earth and the sea, they represent the grandest group of graduated statues for pedimental spacefilling ever conceived by the mind of man. Surely the builder must have made the space for them! That reclining figure has the perfect relaxation of a young woman who has thrown herself on a couch and leaned against her friend for heart to heart confidences. They probably have heard nothing yet of the wonderful birth of Athena, though the older friend, sitting a little apart, seems to be aroused by something unusual. The turn of her neck is toward the centre, the extended left foot and leg and the drawing in of the right indicate that she is about to rise and investigate the cause of the disturbance.

Beyond the reclining figure, in the Three Fates, is a fragment of Selene (the Moon) driving her horses into the sea. The nigh horse, poking its nose over the edge, is instinct with life. An Englishwoman looking intently at the quivering nostrils, confided to me:

"It's so alive it gives me a turn!" In the nostrils and behind the ears is still found a little of the

$$
\text { [ } 182 \text { ] }
$$




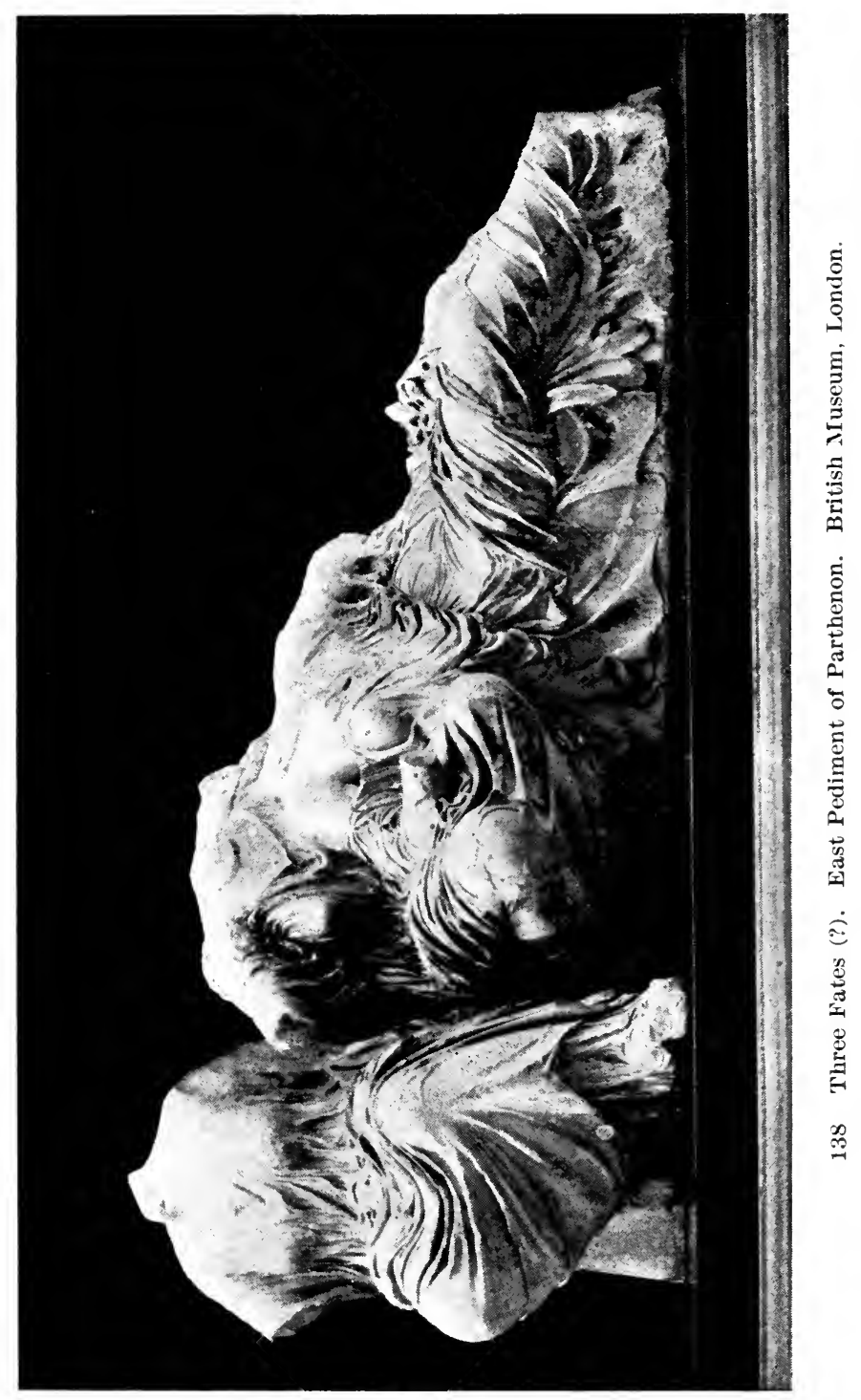




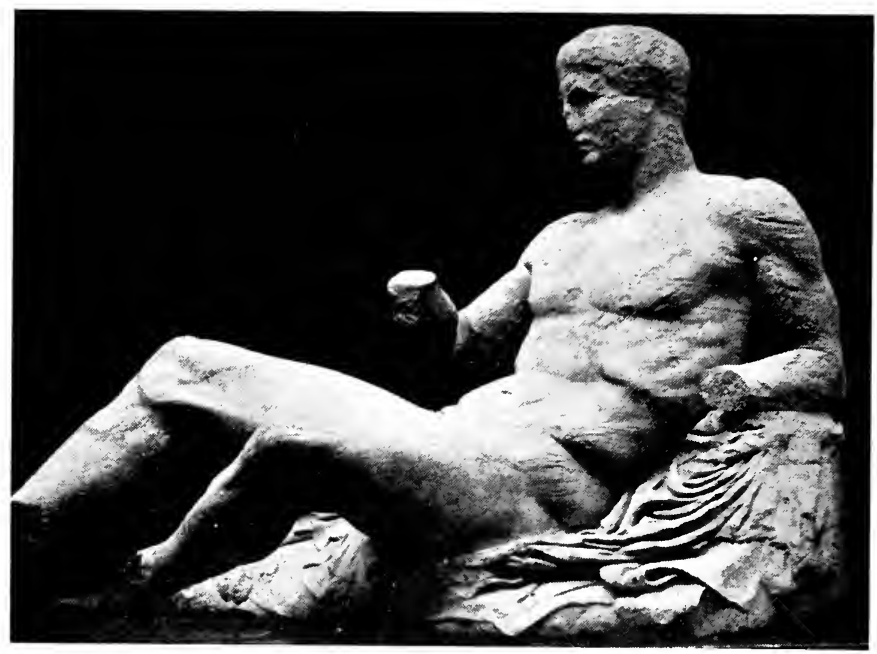
139. Theseus. East Pediment from Parthenon. British Museum,

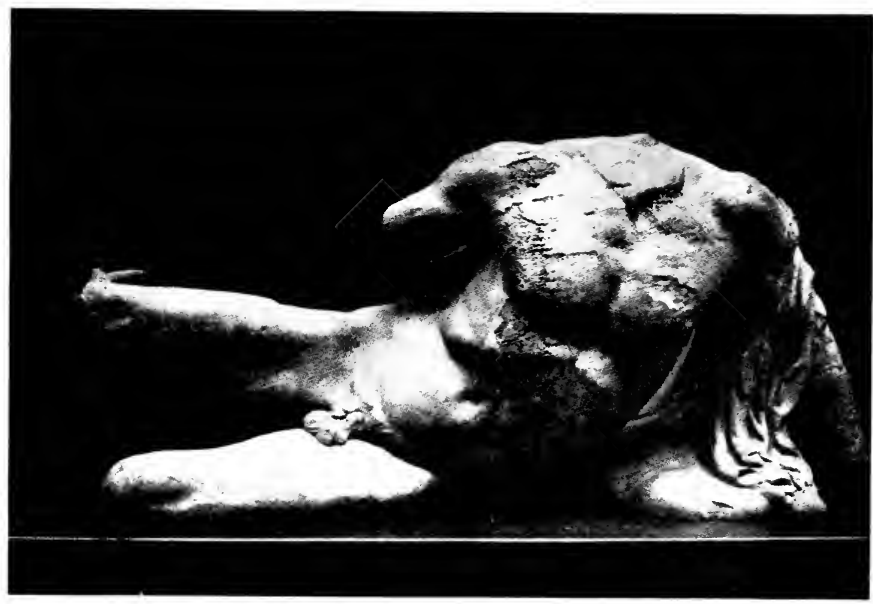

140. Cephissus. West Pediment from Parthenon. British Museum, London. 


\section{LONDON}

original paint-we are confident that the Parthenon marbles were originally in colour.

To the right of the space of the lost Athena group is "Theseus" (Fig. I39), the only figure left with a head and even on this the nose is broken. Here again this god is still unconscious of the great event being passed down to him. Next to the central group is Iris, the messenger of the gods, who is proclaiming the news as she starts away from the scene of action. She has delivered the message to Persephone, who was leaning against Ceres (Demeter), but is now rising to tell her mother.

Theseus, reclining with his face away from the mother and daughter, has heard nothing. What a magnificent figure it is in size, strength of muscle, suggestive bone structure, and firm, warm flesh! The god's rest implies more work to follow. How his discarded cloak crinkles in folds as it falls below his resting arm! This one head gives us some slight conception of the grandeur of the figures when they were perfect.

The central group of the west pediment represented the contest between Athena and Poseidon for the land of Attica. In the Carrey drawing, hanging below the figures, this pediment is shown partly complete. Poseidon (Neptune), you remember, gave the horse, in their contest, and Athena the olive tree. The gods decided in

$$
\text { [ } 183 \text { ] }
$$




\section{WHAT SCULPTURE TO SEE}

favour of the olive tree as the most useful to the people.

At the extreme right of the centre of the west pediment is "Cephissus" (Fig. I40), a river-god; Pausanias says river-gods are quite common figures in Greek sculpture. An ancient writer, in describing the texture of the body, says: "More liquid than water." It takes no stretch of imagination to know that the garment clinging to the left arm is heavy with the water running from its limp folds.

Out of more than four hundred feet of the sculptured frieze of the Parthenon that survived after the explosion in 1674 , two hundred and forty feet are in the British Museum. Let me disabuse your minds of the error of thinking that the two hundred and fifty feet ought to have been left in Greece. When Lord Elgin brought the Parthenon marbles away, he had casts made of the slabs of the frieze left in situ to show the entire set of frieze sculptures-over five hundred feet.

Seventy years later another set of casts were made of the slabs still in Greece, when it was found that many of the reliefs had deteriorated wofully-in one place a man's leg was gone, in another a horse's foot and ear, and still another, parts of a face, etc., which is a convincing argument that Lord Elgin came none too soon to save the precious treasure. To-day the Greek government is taking every precaution to preserve what

$$
\text { [ } 184 \text { ] }
$$




\section{LONDON}

now remains. Lord Elgin claimed to have brought away only the sculptures that were detached from the building.

The subject of the Parthenon frieze is the great Panathenaic procession to the Acropolis in honour of Athena. On the slabs were pictured in low relief more than three hundred and fifty people and about one hundred horses, besides animals for the sacrifice, yet no two figures are alike.

The "Procession of Youths" (Fig. I4I) represents the cream of young manhood in Athens. This very low relief is the most wonderful example of that work that the ancients have left us. How well the restiveness of the horses match the restless impatience of youth. Horses and youths have that nervous, high-strung bearing that points to a long pedigree of nobility. If Pheidias did not carve these splendid youths and their noble horses, he surely designed them. A master mind willed, and they live before us!

As the frieze formed a continuous band of low relief pictures around the main body or cella of the Parthenon under the portico, so the metopes formed a band of high relief pictures around the outside of the building. Each metope or square panel, carved in high relief, alternated with panels carved with sets of vertical bands (the triglyphs). The subject of the reliefs is the famous battle of the Lapith and Centaurs. There are ninety-two

$$
\text { [ } 185 \text { ] }
$$




\section{WHAT SCULPTURE TO SEE}

separate metopes; each one is complete in itself, yet forms a link in the story.

Before the men at the wedding (see page I66) realised what was happening a "Centaur with a Lapith Woman" (Fig. I42) has galloped off, followed by others. The centaur's raised tail and the woman's falling, fluttering drapery intensify the sense of motion! This creature is really not cruel in his excess of fun, only gleefully triumphant as he rushes away with his prize. Though the metopes are unequal in quality, yet some are of great excellence. In this one the rendering of the beautiful contour of the centaur's body, showing skin and veins, and the use of the flying drapery in filling the space above his back, is superb. The resemblance to the portrait of Socrates is often noted in the face of this centaur.

Also the metope of the "Lapith attacking a Centaur" (Fig. I43) is fine. The natural playfulness of the queer creature has here given place to animal fear, for he recognizes that a superior intelligence is conquering. 


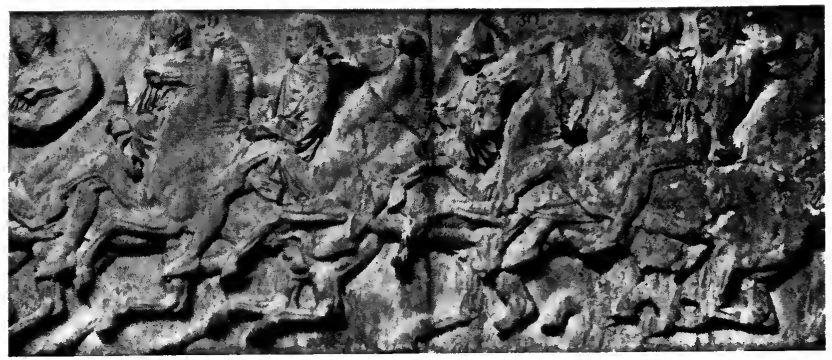

141. Procession of Youths. North Frieze from Parthenon. British Museum, London.

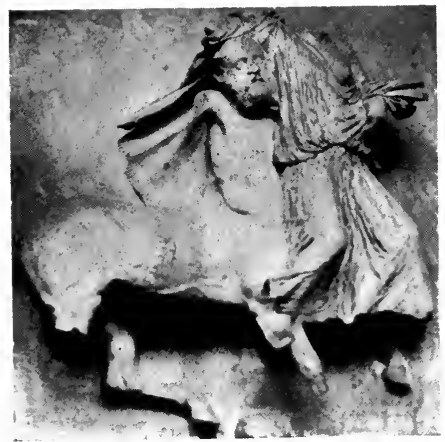

142. Centaur with Lapith Woman. Metope from Parthenon. British Museum, London.

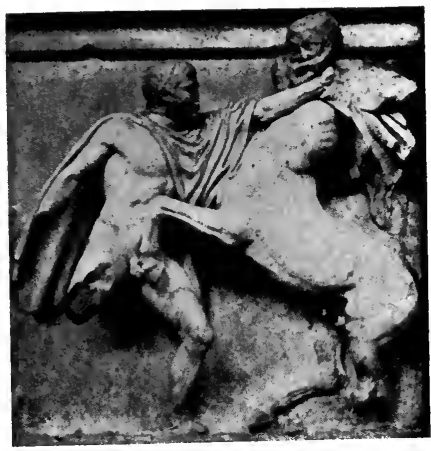

143. Lapith Attacking Centaur. Metope from Parthenon. British Museum, London. 

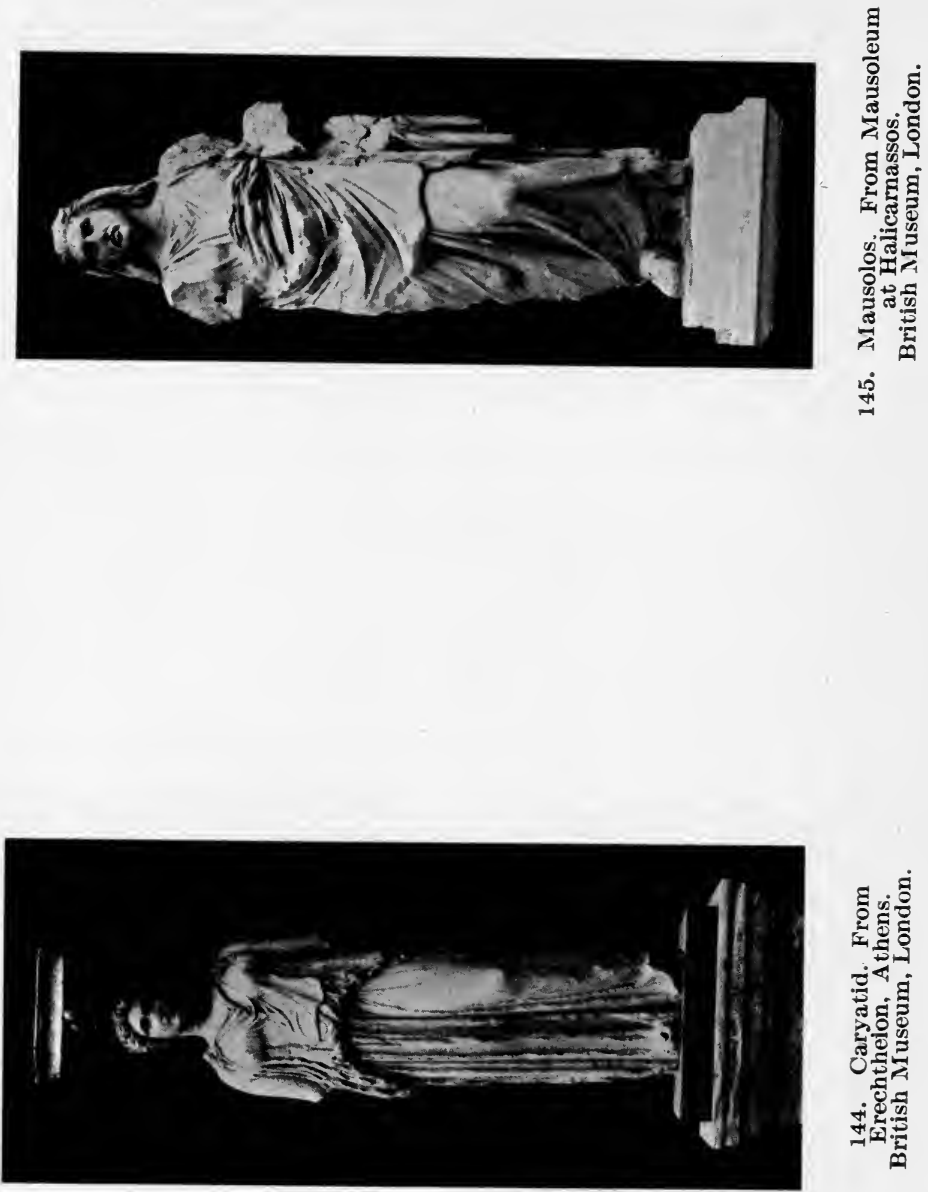

(1) 


\section{CHAPTER XX \\ LONDON-ANCIENT SCULPTURE, BRITISH MUSEUM (Continued)}

IN the same room with the Parthenon Marbles 1 is a single "Caryatid" (Fig. I44), from the Erechtheum, Athens. The Erechtheum was a temple probably dedicated to Athena and Erechtheus. Homer says in the Odyssey: "And (Athena) came to Marathon and Athens with its spacious streets, and entered the well-built house of Erechtheus," but in the Iliad he states that Athena received Erechtheus in her own rich temple. At least we may conclude from these two references that the original temple was a very ancient one and that Erechtheus was a national hero and that Athena was the goddess of Athens.

On the west end of the temple is the portico of "The Maidens," later called "Caryatids." The latter name possibly may come from the town of Carya in Arcadia, for the story is that after the battle of Thermopylæ the inhabitants of Carye sided with the Persians. But the victorious Greeks, to punish them, put the men to death and sold the women into slavery. As a constant reminder of the event female figures were carved as supports of

$$
\text { [ } 187 \text { ] }
$$




\section{WHAT SCULPTURE TO SEE}

the temple. If this burden-bearer was intended to degrade womanhood, the sculptor certainly has frustrated the intent. Could anything express greater ease of bearing or queenliness of manner than this superb maiden in the full bloom of young womanhood? The burden she bears rests on her head as lightly as a royal crown. Her ample drapery, falling in large, simple folds, suggests the stability of a marble column. Not simple burdenbearers are these maidens of the Erechtheum, but devoted guardians of the temple of their goddess.

The Mausoleum of Halicarnassos and the Taj Mahal at Agra stand as the acme of artistic memorials erected in honour of loved ones-the former for a husband the latter for a wife. The statue of "Mausolos" (Fig. I45) gives us some conception of the man who inspired such depths of love in Artimisia his wife. She not only built this monument to him, that the ancients called one of the wonders of the world, but, story says, "drank of his ashes that she herself might be his tomb." Marred and broken as it is, the statue holds us with its calm dignity. The fitting words of Mausolos' shade, given in Lucian's decalogue, certainly describes the statue. "I was a tall, handsome man, and formidable in war," it says. This stupendous masterpiece to Mausolos has given its name to all like monuments for more than two millenniums.

Mausolos, a prince of Caria, who died in 353 [ 188 ] 


\section{LONDON}

B. C., married his own sister Artimisia. For twenty-four years he ruled southwestern Asia, and taking the Greek town of Halicarnassos as his capital, laid out, in a semicircle along the bay, one of the most magnificent cities of the ancient world. The mausoleum probably stood at the centre of the great city, a spot chosen by Mausolos and dedicated to him by his devoted wife and sister. The history of the destruction of the great masterpiece is a repetition of what so often happened to the ancient marvels of the art world.

It was not until I 857 , when Professor Newton began his systematic excavations, that the real magnificence of the tomb was realised. Even now it is hard to comprehend its bigness from the fragmentary marbles in the British Museum. We must remember that much of the tomb still remains buried on the ancient original site, also that a large number of the marbles were built into the walls of a palace at Budrun in the fourteenth century and are there to-day, and that many of the sculptures are buried in the museum at Constantinople where they are quite as inaccessible as the unexcavated at Halicarnassos.

When Professor Newton uncovered slabs of the Amazon frieze, about eighty in number, he found them beautifully finished and highly coloured-the background an ultramarine, the flesh tints a dull red and the drapery vermilion-which indicates that

$$
\text { [ I } 89 \text { ] }
$$




\section{WHAT SCULPTURE TO SEE}

the whole frieze of about four hundred feet was a brilliant band of exquisite colour and finish circling the base of the Mausoleum. The slab of "The Amazons Fighting" (Fig. I46), where two of the female warriors are getting the best of their foes, is delicious in its feminism. Could anything be more like a woman than the tempestuous onslaught of these two? These are out to win and they stop at no tactics, however irregular, to accomplish their purpose. Look at the one sitting backward on her war horse! She is perfectly unconscious of fear; her left leg clings to her mount as though it were a part of the horse, and the force of the right knee is simply tremendous in its purchase. And what an exquisite body she has! The other Amazon grabs the protecting shield of her opponent with her left hand and with the right arm uplifted is ready to strike across her own arm at the unprotected foe. Unafraid, undaunted and often unreasoning in their mode of warfare, these superb women fight for their rights. Never for one moment does the sculptor lose sight of their exquisitely formed bodies and their tremendous courage.

The Amazon frieze is of coarse-grained Asia Minor marble and the artistic quality of the work is very unequal. Athenian sculptors decorated it and, according to Pliny, Scopas carved the east, Leochares the west, Bryaxis the north, Timotheos the south, and Pythios the quadriga at the summit

$$
\text { [ } 190 \text { ] }
$$




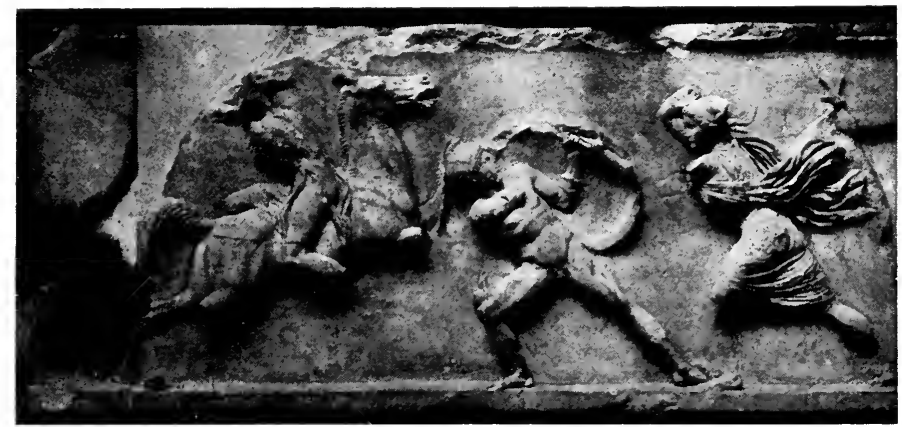

146. Amazons Fighting. Mausoleum Frieze. British Museum, London.

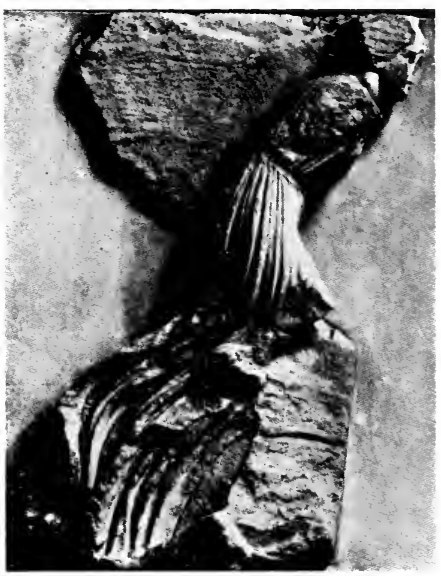

147. Charioteer from Small Frieze. British Museum, London.

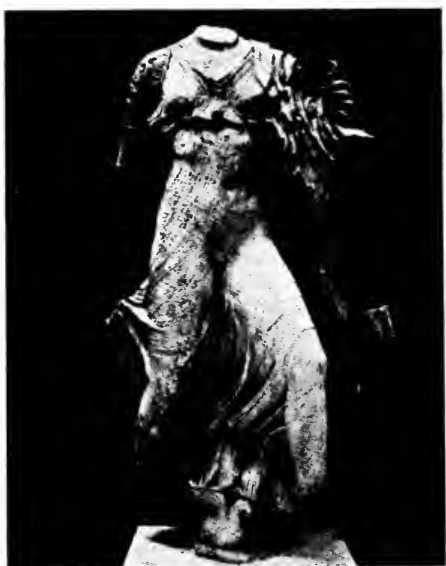

148. Nereid or Sea-Nymph from Xanthos. British Museum, London. 

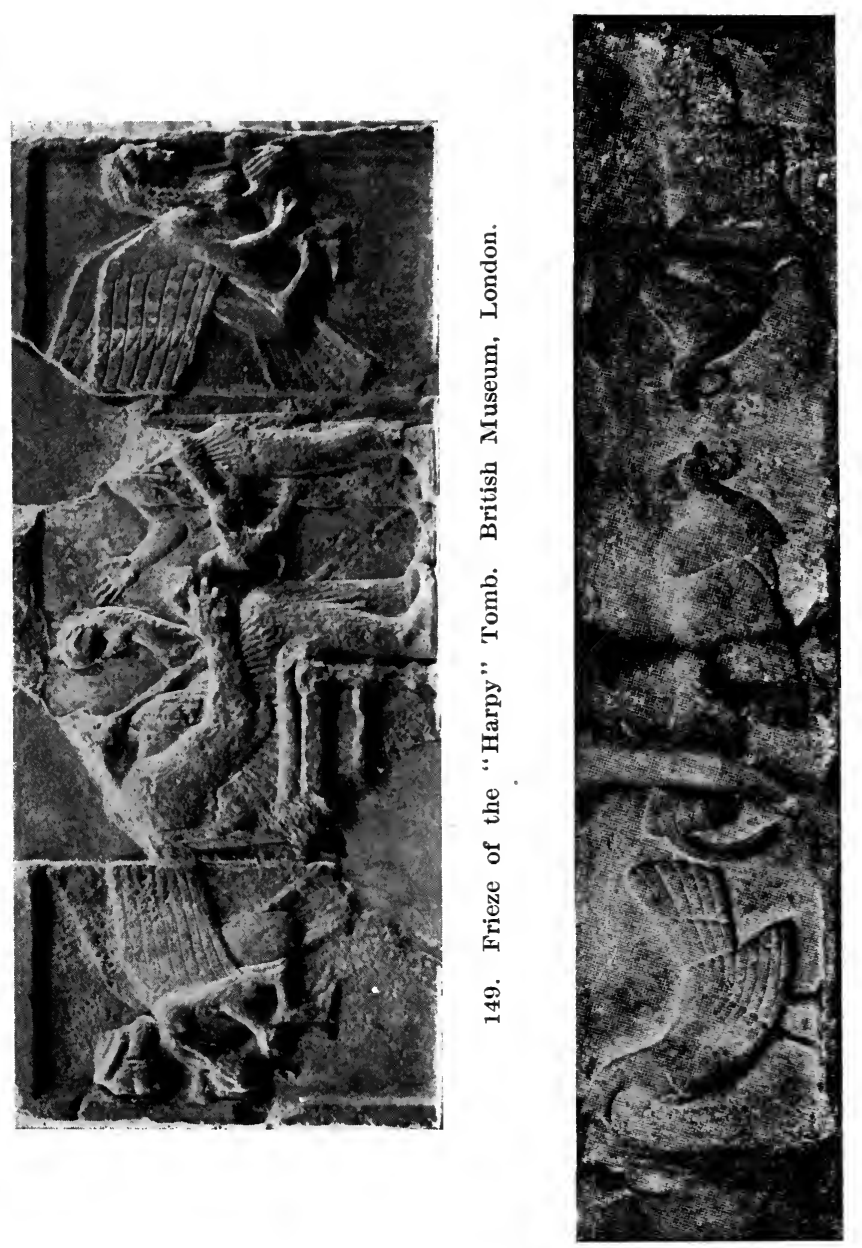

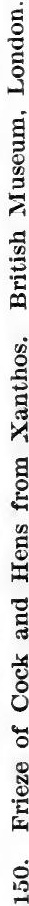




\section{LONDON}

where Mausolos stands. The figure beside him may be Artemisia, though some critics believe it is a goddess conducting the hero to immortality. Pliny also adds, "The rivalry of the different hands was evident."

A second frieze of the Mausoleum, the conflict of the Lapiths and Centaurs, has but two fragments in the British Museum and these are too meagre for definite examination. Then came a third frieze which represented a chariot race, doubtless a vivid picture of the funeral rites of Mausolos. The most beautiful bit of this frieze is the "Charioteer" (Fig. I47), placed low on the wall in the Museum so we can examine his face. The finer marble and the delicate finish point to the famous Scopas himself. Certainly nothing could be more exquisite than the eagerness of the slender boyish figure bending to the flying steeds while urging them on with caressing voice and gesture. The long, flowing robe, common to the ancient charioteer, floats out behind, completing the rhythm of the rushing horses with the balancing force of the youth between.

At the head of the steps out of the Mausoleum room is the "Nereid" or "Sea-Nymph," from Xanthos (Fig. I48). She is one of a number of statues that once adorned the tomb of a rich satrap of Lykia, Asia Minor. The monument once crowned a hill at Xanthos (a town of Lykia)

$$
\text { [ I9I ] }
$$




\section{WHAT SCULPTURE TO SEE}

where the high base is still in situ. The restored building in the same room, surrounded by Ionic columns with a central tomb chamber, gives some idea of the beauty of the original monument about the year 370 B. C., when it was finished.

The light, airy, swift moving Nereids have given their name to the tomb. They originally stood between the columns and may have represented the sea-breezes. At least they seemed poised in mid-air and only held to earth by some persistent water animal clinging to their flying garments.

The Nereids were the daughters, fifty of them, of Nereus and Doris. Thetis, one of the daughters, was very beautiful, and as usual Zeus fell in love with her and sought her in marriage. But when he learned from Prometheus, the Titan, that Thetis' son would be greater than his father, Zeus decreed that she should marry a mortal. At last Peleus, aided by the Centaur Chiron, won the goddess Thetis, and their son was the renowned Achilles. Possibly the dainty maiden in the illustration is Thetis herself. The ancient belief that the Nereids were connected with the Isles of the Blest, the home of departed souls, explains why they are pictured on a tomb; and remembering that Thetis conducted Achilles to these isles to become immortal, it would not be strange for her to accompany a satrap's soul to its future home.

That the Nikians must have had some intima-

$$
\text { [192] }
$$




\section{LONDON}

tions of immortality is again shown in the so-called Harpy Monument from Xanthos, in the Archaic Greek room. In the "Frieze of the Harpy Tomb" (Fig. 149) those curious creatures with egg-shaped bodies are supposed to be the conductors of souls in the form of little children. Many and varied are the explanations of the strange beings on these reliefs. At one time the winged, oval-bodied females were called Harpies (snatchers), hence the name of the tomb; but their mild, inoffensive faces and caressing ways do not fit the disgusting creatures that carried off and defiled everything they touched.

As the town of Xanthos was nearly destroyed by the Persians in 546 B. C., the Harpy tombs were probably made earlier than that date.

Another interesting relief in this room is the "Frieze of Cocks and Hens" (Fig. I 50). We recognise at once the hand of the genre artist, who has portrayed nature first hand. $\mathrm{He}$ has given us a common every-day scene of the barn yard, and has portrayed it with the vivid touch of the Dutch genre painters of the sixteenth century. These bits of nature study that flash out at us from among stiff archaic sculptures are delicious in their quaint realism.

In the room with the Lykian friezes is a bronze statue of "Marsyas" (Fig. I5I), found at the seaport city of Patras, Greece. This statue is

$$
\text { [ } 193 \text { ] }
$$




\section{WHAT SCULPTURE TO SEE}

scarcely more than two feet high and, like the original Myron statues, has the attitude of disappointment and even fear. You will remember that Athena, displeased that Marsyas picked up the discarded flute and made music on it, appeared before him, which caused his sudden start of fright. This bronze Marsyas and the marble Marsyas, in the Lateran (see Fig. $5 \mathrm{I}$ ), give some idea of what the beauty of Myron's originals must have been. Then, too, figures of Athena and Marsyas have been found on an Athenian coin, a vase, and a relief, which seem to verify Pliny's mention of such a group by Myron.

One of the most charming bits of realism in the British Museum is "The Boy Extracting a Thorn from his Foot" (Fig. I 52). Is it possible that the little fellow is only marble? So real are his efforts that we listen for "ouch" to come from his open lips, as he probes deep for the offending thorn. We love him, this homely tousle-headed peasant boy! It was only a moment ago that he was entertaining us with circling hand-springs, while tormenting us for "pourboire"! How wonderfully every muscle swells under the strain of his position and how perfectly at ease is the doubled-up body! Only a vigourous, naturally developed child could twist his legs with the bottom of the foot turned upward. The sculptor, whoever he was, not only saw this boy, but himself felt the pricking of the

$$
\text { [ I94] }
$$




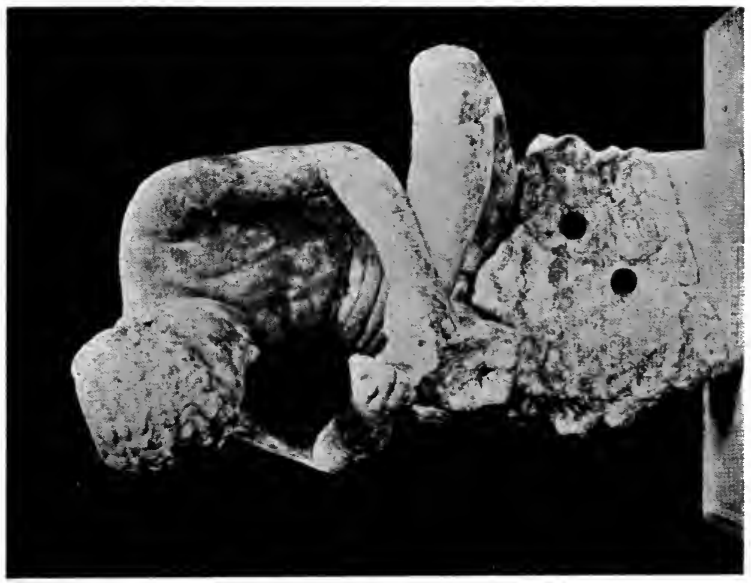

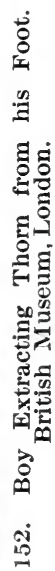

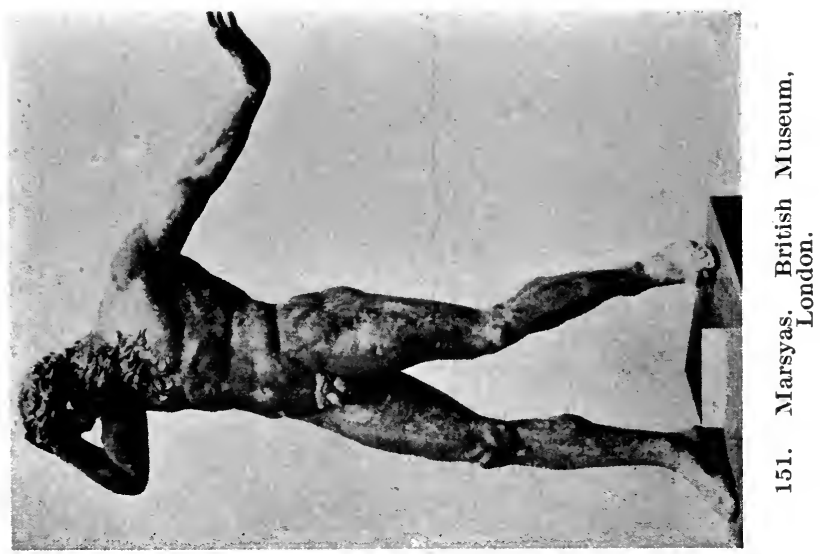





\section{LONDON}

thorn. He understood boy life and had sympathy for the boy in trouble. This boy belongs to no special country or time, though the original of the statue was probably made in the Hellenistic age of Greek art. But where does not the barefoot boy get the troublesome thorn in his foot? and where was it ever extracted more easily? 


\section{CHAPTER XXI}

\section{LONDON-BRITISH MUSEUM, EGYP- TIAN AND ASSYRIAN SCULPTURE}

$7 \mathrm{HE}$ tremendous size of Egyptian sculpture in 1 the British Museum, and the overwhelming number of examples, and the thousands of years represented are so overpowering that our minds refuse to grasp the significance of the collection. We walk among the colossal statues like pigmies among giants. We wonder if a people who conceived such tremendous works of art could ever give thought to the individual. But stop a moment and look at the "Book of the Dead," in a case in the centre of the gallery. In one chapter it reads: "I have given bread to the hungry. I have given water to the thirsty. I have given clothes to the naked." Could anything be more Christianlike? and yet part of the "Book of the Dead" dates back to the First Dynasty about 4400 B. C. The "Rosetta Stone," the wonderful key to the Egyptian language, is near by.

The religion of the Egyptians was polytheistic, yet they believed in God and in a future state. At death the soul, the $\mathrm{Ba}$, left the body only tem-

$$
\text { [ } 196 \text { ] }
$$




\section{LONDON}

porarily, hence the latter must be preserved intact. Also a likeness of the deceased and familiar domestic scenes must be in the tomb chamber to guide the soul back to its old home. Naturally size and durability became the distinguishing characteristics of the statues and monuments of this people of the Nile.

The fact that the soul, or $\mathrm{Ba}$, must be able to recognise its earth body when it returned had great influence on the portrait sculpture of ancient Egypt. Even statues found in the oldest mastaba tombs are portraits of marvellous life-like characteristics. Many of these statues were made of the hardest and most obdurate material, yet the sculptor has worked out the features, slightly emphasising this peculiarity or that, until we feel the character of the man within the stone image.

Then, too, certain conventional ideals grew up that stood for special individuals and these were worked into statues and often the two, the portrait and the conventional, were put into the same tomb and both were equally true to the same man. The work of the early artists undoubtedly gives us the truest picture of the Old Kingdom of Egypt. M. George Perrot, a classical archæologist, says of these old sculptors, "It must be acknowledged that they produced works which are not to be surpassed in their way by the greatest portraits of Modern Europe."

$$
\text { [ } 197]
$$




\section{WHAT SCULPTURE TO SEE}

If you have time, go upstairs to the third Egyptian room, and in table case L look at a tiny "Ivory Figure of a King," possibly of the First Dynasty. It is a very beautiful bit of carved ivory, with wonderful portrait qualities. That the figure represents an old man is very forcibly told by his trembling grasp on the heavy checkered garment wrapped around his stooped shoulders. One can fairly see him shiver under the warm cloak.

To really comprehend the gigantic stone statues in the main gallery we must study some particular one and learn $a$ little of the life story of the person represented. Let us take this splendid bust of "Thothmes III" (Fig. I 53), of the Eighteenth Dynasty, about I 550 B. C. It represents the greatest of all the kings of Egypt. Thothmes III was the son of Thothmes $I$ and an obscure concubine named Isis. $\mathrm{He}$, like his father before him, procured the throne of Egypt through his wife Hatshepset. She was the daughter of Thothmes I and Ahmose, the queen who had the real title to the throne. To make matters worse for Thothmes III, he was forced to acknowledge the co-regency of Hatshepset, his wife and half sister in one. His position at court was not a pleasant one; in fact he was pushed into the background until he became a mere nonentity under petticoat rule. This state of affairs lasted for twenty-one years, when Hatshepset died.

$$
\text { [ 198 ] }
$$




\section{LONDON}

Queen Hatshepset was a powerful ruler, and the first great woman recorded in history. She erected wonderful monuments, a beautiful temple to herself at Der el-Bahri and two obelisks in her father's hall at Karnak, but she was a misfortune to Egypt, for she neglected the foreign power of the country in Asia and Syria.

Thothmes III was not kind to the memory of Hatshepset, and who could blame him! He at once had her name and figure hacked out of all the temples and buildings she had erected from the Delta to the Cataracts, and around the base of the obelisks at Karnak he had a casing made to cover her name and the record of her building them. Probably her $\mathrm{Ba}$ is still looking for its home and her $\mathrm{Ka}$ (double) is wandering to find its own likeness.

Now Thothmes was ready to rule Egypt and gain the country's waning power in Asia and Syria. For thirty-two years he went "forth at the head of his army himself, showing the way by his footsteps." Soon he controlled all Palestine as far north as the southern end of Lebanon and as far inland as Damascus, and even far-off Babylon sought his good will. At last he "crossed the great Bend of Naharin (the Euphrates) with might and with victory at the head of his army." At this time the Hittites first appeared on the stage of history. So great became the name of Thoth- 


\section{WHAT SCULPTURE TO SEE}

mes III that "centuries after his empire had crumbled to pieces it was placed on amulets as a word of power." He reigned alone thirty-two years.

The Nineteenth Dynasty was opened by Rameses I, about I3I 5 B. C., some two hundred years after Thothmes III. Rameses was an old man, and in two years he was succeeded by his son Seti I, who reigned twenty years. At his death his younger son, Rameses II, brushed aside the real heir and ascended the throne. This act alone characterises his whole life. Look into the face of this bust of "Rameses II" (Fig. I 54) and see how selfish ambition and conceit are written on every feature. The bust is from one of the pair of statues that stood in the "Ramesseum" at Thebes. Rameses II was the Sesostris of the Greek writers and the Pharaoh of the Oppression. He reigned sixty-seven years and died when about one hundred years old. He is said to have had one hundred sons and fifty-one daughters, and wives too numerous to mention.

That Rameses II was a great builder is true, but it is equally true that he did not build everything on which is found his name. Nothing seems to have pleased him so well as to see his name in public places, consequently no repairs, however small, that he had made on a monument or temple prevented him from appropriating the whole work as his own. Few, very few, are the buildings in

$$
\text { [200] }
$$




\section{LONDON}

Egypt where his name does not appear on some chamber, hall or column.

But Rameses II really did erect some wonderful buildings himself. The rock-hewn temple of AbûSimbel alone was a marvel of size and magnificence. In front of this temple are four colossal statues of the king, each ninety feet in height. And again at Thebes he built the "Ramesseum," that Strabo called the "Memnonium." One of the statues now lying in fragments on the original site weighs one thousand tons. These monolithic statues of Rameses II are the greatest ever made. The one at Tanis was of a single block weighing nine hundred tons.

A very curious large carved stone in the Egyptian collection is a huge black "Scarab," the scarabæid beetle or Ateuchus sacer. This strange animal was worshipped by the ancient Egyptians as representing fertility and the resurrection. The Egyptian scarabs are carved in the shape of a beetle. The back of the insect is exactly reproduced; the legs, seen on the sides, are drawn under the shelllike wings and the underside is engraved like a seal. The scarab is of all sizes and carved in all kinds of material, from the semi-precious stones to baked clay. They were placed in the mummy cases of the dead.

It is impossible to trace Babylonian and Assyrian [201 ] 


\section{WHAT SCULPTURE TO SEE}

history back of two thousand years B. C. The origin of the old Babylonian empire is still wrapped in mystery. In Genesis X. 8-I I, we read that Nimroud came into the country and built Babel (Babylon) on the Euphrates. Some authorities believe that he was a Sumarian from Central Asia. At any rate these invaders amalgamated with the natives, and gradually an empire was formed that pushed its way to the Tigris, and Ashur built the city of Nineveh.

About I 700 B. C. Assyria became a separate kingdom, and from that time until the Persian rule the two nations, Babylonia and Assyria, were constantly at war for supremacy-the latter usually victorious. The sculpture collected in the British Museum is mostly Assyrian.

One of the greatest of Assyrian kings was "Ashur-nasir-pal" (Fig. I55). He was a conqueror, an extensive builder and an art promoter. $\mathrm{He}$ ascended the throne 885 B. C. When he moved the capital from Ashur to Nimroud (Calah of the Bible), he built a magnificent palace and decorated it with most elaborate reliefs of domestic scenes, religious ceremonials and strange animal monsters. But across every decoration is an inscription recounting the greatness of Ashur-nasirpal, the king, the supreme ruler, the head and centre of all. In the human-headed monsters appear the king's own likeness. One is led to be- 

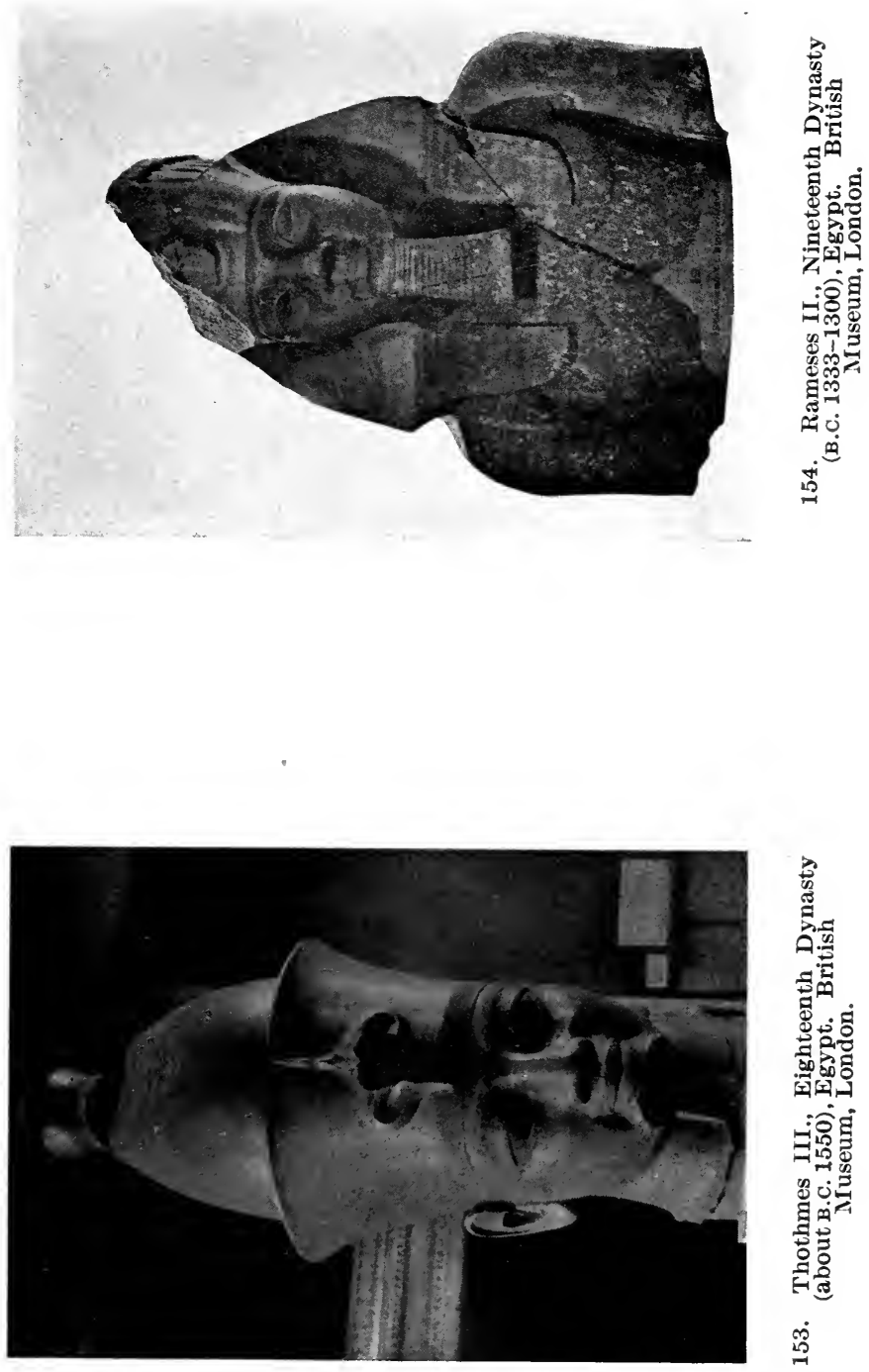

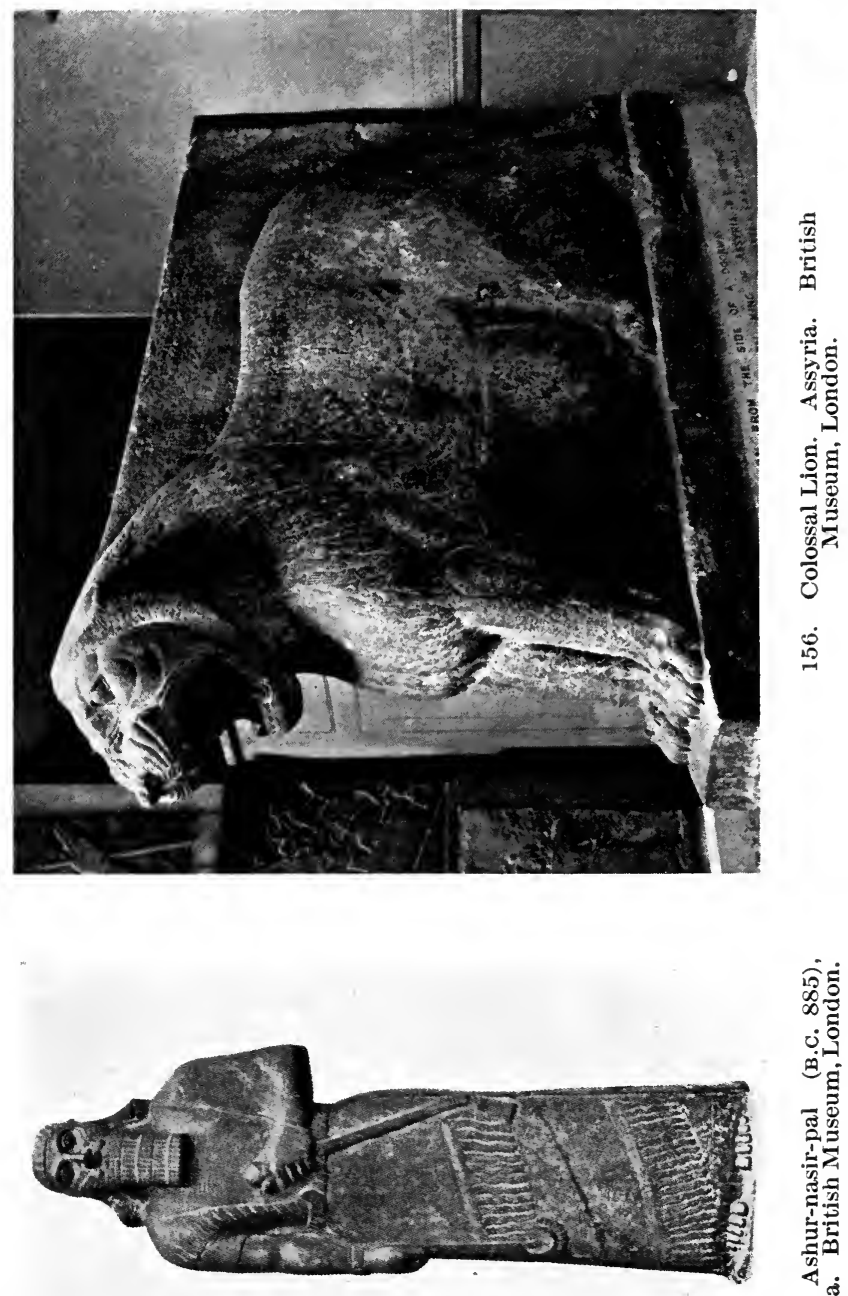

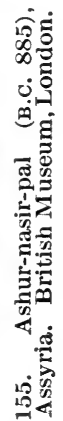




\section{LONDON}

lieve that "art for art's sake" was secondary to exploiting the greatness of the king.

The small statue of Ashur-nasir-pal, of our illustration, is specially interesting as being the only Assyrian royal statue made in the round ever found perfect. It was found in a small temple to Adar, one of the war gods, and still stands on its original limestone base. You will notice that the form of the body can be traced under the drapery and fringes of the back, yet the side view still has the appearance of relief-work. The sculptor has gone a step forward in setting the figure free, but he has neglected to remove the signs of his former bondage.

In the "Colossal Lion" (Fig. 156), from the portal of a small building at Nimroud, is also an exception in Assyrian sculpture because it is a pure lion. A splendid fellow he is too! As a guardian, nothing could surpass him. Who would dare enter unbidden with those yawning jaws and glaring eyes barring the way! but when once we have passed the defiant front, how different is our impression of him. The fifth leg, seen only from the side of the huge figure, shows him calmly walking away, as though his work were done. This curious and unusual device is very effective and gives one the impression that the king was indeed supreme in his own empire, but must be guarded from foes without.

$$
\text { [203] }
$$




\section{WHAT SCULPTURE TO SEE}

It was doubtless during the reign of Ashur-banipal, 683-620 B. C., that "Nineveh was an exceeding great city of three days' journey." Jonah iii : 3 . The palace walls of the king were of alabaster, and on them were pictured in low relief the king's hunting expeditions. From his own words we read, "I, Ashur-bani-pal, king of hosts, king of Assyriaslew four lions-and I poured out a libation over them." One relief pictures this scene, thus verifying the king's word picture. Notice, in all these hunting scenes, how few lines are used to portray the figures and that there are no accessories of trees and rocks, yet could an open country be more vividly pictured than is done in the racing horses, the fleeing deer, the flying birds, and the closely pursued lions?

The very perfection of animal portraiture is reached in the "Dying Lioness" (Fig. 157). The sculptor has not troubled himself to perfect bone, muscle and sinew, but he has sent the arrows through the animal's very centre of activity-the spinal cord. She is not writhing with pain, this matchless creature, but is snarling with rage. She is helpless. The sting of the shoulder wound no doubt goads her on, but it is the heavy helpless parts dragging on her powerful fore legs that angers her. This is one of the most superb animal portraits, where the portrait is still pure animal, in all art. One wonders if Jonah stood, as we stand, 


\section{LONDON}

before these vivid pictures and commented on their value as works of art!

In a measure, it is almost absurd to turn from these Assyrian animals, so perfectly pictured with a few simple lines, to Landseer's humanised "Lion" (Fig. I 58), in Trafalgar Square. There they stand, the quadruple one, like a stationary compass pointing north, south, east and west.

Landseer struck a new note in art in England, the middle of the nineteenth century, by going to nature for his subjects. The people were tired of the artificial prettiness of the later portrait painters; an artist who could give something unusual was welcomed with enthusiasm and Landseer became the idol of his times. What an opportunity to guide and educate the popular taste for real art in genre subjects! and how far short he fell! $\mathrm{He}$ modelled splendid animals, if only he had treated them as animals and given us real horses, dogs and lions. But no, into the face of each has crept his own emotions until the human element has smothered the real animal.

The four lions guarding the base of the Nelson shaft are magnificent fellows in size and form, but too suggestive of the limits of a cage for active protectors of a national hero. 


\section{L'ENVOI}

It is with real regret that I say au revoir as our little trip together to the Sculpture galleries of Europe closes. You, my travelling companions, now know that it has required great self-restraint to adhere to my original plan of noting only a few masterpieces. If, however, one-half of the joy and uplift has come to you in looking at the few great pieces of sculpture pointed out that has come to me in preparing the little guide I shall know that this book is not in vain.

I now cordially invite you and your friends to consider with me, next year, "What Pictures to See in America," and then, later, I hope to look at architectural masterpieces in Europe with you.

\section{[206]}




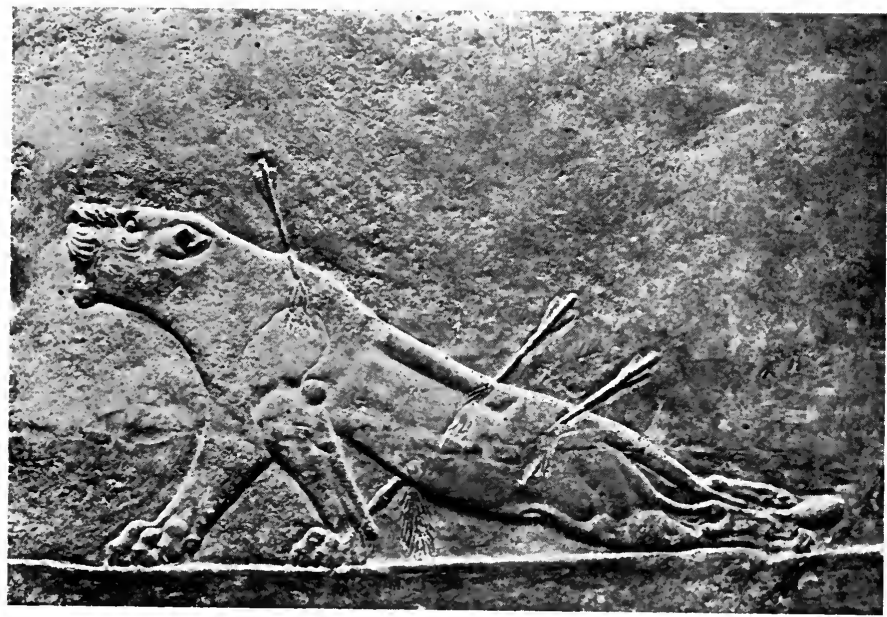

157. Assyrian Lioness. From Palace at Nineveh. British Museum, London.

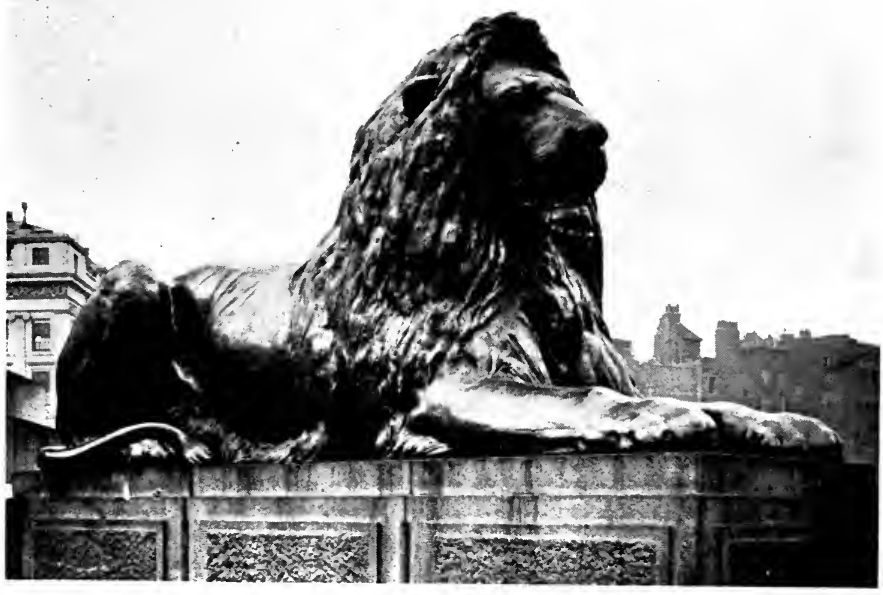

158. Lion. By Landseer. Trafalgar Square, London. 


\section{INDEX}

A

Achilles, 91, 192

Actæon, 152

Agasias, 149

Agrippa, 54, 69

Agrippina, 69

Aigina Marbles, 124-127

Alcamenes, I38, I49, I 54, I 55

Alcestas, $\mathbf{I} 78-\mathrm{r} 79$

Alexander, 39, 58, 74, 75, 91, 132, 1 50, 179, 195

Amaltha, 32

Amazon, 30-32, I40, 141, 189-191

Andromeda, 66, 67

Angelo, Michael, 21, 36, 50, 56, 62, 63, 77-80, 92, 94-99,

I01, 103, 104, 108, 160-162, 172

Antenor, 40

Antiope, 34, 35

Aphrodite, 22, 24-25, 42, 44, 45, 65-66, 70-71 , 74, 89, 90,

$$
\text { 138, 145, 147, 149, } 163
$$

Apollo, 42-44, 46, 82, 85, 87, 90, 102, I I8, I27, I47, I48,

$$
\text { I5 } 1,163,178
$$

Apollonius, 34, 50, 90

Arachne, 33-34

Ares, 73, 74, 75, 154-155

Argus, 27, I19

Ariadne, 54, 55 


\section{INDEX}

Aristogeiton, 38-4I

Artemis, 31, 43, 50, 85, I40, I 5 I, I 52, I78, I79

Artimisia, I88, I9I

Ashur-bani-pal, 204

Ashur-nasir-pal, 202-203

Atalanta, 50

Athena, 24, 25, 32-34, 47, 49, 57, 82, 93, 118, 125, 126,

I27, I 28, I39-140, I47, I48, I75, I80-186, I 87, 194 Attala, King, 30, 32, 73

\section{B}

Bacchus, see Dionysos

Baptistry Gates, I04-I I I

Bartolomé, Albert, 175

Barye, Antoine, 166-17I

Bellini, I20

Böethos, 58, 133

Bologna, Giovanni da, I04

Book of the Dead, 196

Botticelli, 7I, 95

Bronze Horses, II 5-I I6

Brunelleschi, 104, 105

Cæsar, 38, 60, I49, I62

Caligula, 38, 42, 69

Calliteles, I 26

Candlestick, Seven-branched, 80-8I

Canova, 6I, 163, I64

Caravaggio, 128

Carrey, 180, 184 


\section{INDEX}

Caryatid, 187-188

Cellini, 92, 103, 104

Centaur, 166, 167, 185-186, 191, 192

Cephissus, I 84

Ceres, see Demeter

Chapu, 164-165

Cicero, 53, 67, 68

Cleomenes, 90

Cnidus, 25, 44, 45, 47, 66, 89, 177, I78

Colleoni, I I 7-I I 8, I I9

Credi, I 14

Cretius, 40, 4I

Cronus, 48

Cupid, 22-24, 45, 46, 74, 82, I63, I64

D

Danæ, 93

Dante, 173

David, 94-96, 102, 103

Della Porta, 36, 68

Delphi, 43

Demeter, $177-178$, I 83

Demosthenes, 59-60

Diana, see Artemis

Dionysos, 29, 55, 67, 68, 69, 83, 98, 99, 130-131, 136-138,

$153,155-156$

Dirce, Queen, 34-35

Discord, 25

Discus Thrower, 52, $13 \mathrm{I}$

Donatello, 90, 94, 100-103, 107, I I I, I I 2, I62, I 7 I

Dubois, Paul, I7I

[209] 


\section{INDEX}

E

Echo, 28

Eirene, 129

Elgin, Lord, I8I, I84-I85

Endymion, 66

Erechtheum, I87-I88

Eros, see Cupid

Faun, 64-65, 132, 152

Flora, 25-26

Forum, 8I, 82

Foundling Hospital, I I2, I 13

G

Galatian, 43, 6I, 63-64, 72-73

Ganymede, 53-54

George, Saint, 100-103

Germanicus, 69

Ghiberti, I04-I Io

Giotto, I I I, I I 2

Glycon, 36

Goethe, 74

Gorgon, 42, 67, 126

$\mathrm{H}$

Harmodios, 38-4I

Harpies, 193

Hatshepset, 198-200

Hebe, 54 


\section{INDEX}

Helios, 44

Hellenistic Period, see Alexander

Hera, see Juno

Herculaneum, 21, 26, 29, 38

Hercules, 36, 37, 50, 51, 54

Hermes, 26, 27, 46, 47, 65, 68, 93, 104, I18, I19, 153 ,

$$
\text { 157-158, I 78, I79 }
$$

Herodotus, 179

Hipparchus, 40

Hippias, 40-4I

Hittites, 3 I, 199

Homer, 37-38, 54, 74, 142,187

Houdon, 166

Hugo, Victor, 174, 175

Io, 27

Joan of Arc, 164-166

Jonah, 204-205

Jove, see Zeus

Julius II., 77, 98

Juno, 24, 25, 27, 54, 74, 75, 156

Jupiter, see Zeus

J 


\section{INDEX}

Lapith, 166-167, 185-186, I91

Latona, 43, 85-87

Leochares, 53, 190

Leopardi, I 9

Lilith, 122

Loredano, 120

Lucian, 4I, 44, 48, 52, I 88

Lycurgus, 83

Lycus, 35

Lysippus, 26, 54, 74, I4I

\section{M}

Marceaux, Saint, 172

Marcus, Aurelius, 6I-62

Mars, see Ares

Marsyas, 82, 90, 9I, I3 I, I43, I50, I93, I94

Masaccio, 103

Mausolos, I88-I9I

Medici, 47, 87, 89, 90, 92, 96-98, 163, I75

Medusa, 32, 71-72, 92, 93, I26, I27-128, I48, I 53-1 54

Meleager, 49, 50

Mercury, see Hermes

Metis, 48

Midas, I30, 131

Minerva, see Athena

Moses, $77-78$

Myron, 52-53, 83, I31, I43, 194

$\mathrm{N}$

Napoleon, 38, I 16,163

Narcissus, 28, 127, 172 


\section{INDEX}

Neptune, 33, 34, 57, I80, 183

Nereid, 19I-192

Nero, 42, 76, 90, II 5

Nesiotes, 40, $4 \mathrm{I}$

Nicolo, 120

Nike, 144-145, I 53

Nile, $58,59,60,163$

Niobe, 49, 61, 85-89, 91, 127, I54

Notre Dame, $174^{-1} 75$

O

Onatas, 125, 126

$\mathbf{P}$

Pædagog, 88-89, 154

Pallas, see Athena

Paris, 25

Parthenon, 47, I39, I47, 158-1 59, 167, I77, I80-1 86, I 87

Pausanias, 30, 40, 4I, 47, 49, I29, I34, I38, I39, I80, I 84

Peleus, 25

Père-Lachaise, $175-176$

Pergamon, 21, 30, 31, 32, 63-64, 72, 73, 91, 134-140,

$$
142,149,150
$$

Pericles, 83,180

Perrot, 197

Persephone, 177-179, 183

Perseus, 66-67, 92, 93, 102, 163

Phidias, 4I, 47, 48, 52, 7 I, I30, I33, I38-140, I47, I48, $158,160,175,180-186$

Phryne, 45-47, 447

Pisano, I IO-III

Pisistratus, 40-4I 


\section{INDEX}

Plato, 29, 68

Pliny, 35, 4I, 46, 53, 56, 58, 66, 140, 190, 191, 194

Plutos, 129

Polycletos, 36, 59, I40, I4I

Pompeii, 21, 26

Poseidon, see Neptune

Praxiteles, 2I, 25, 39, 44-47, 49, 61, 64, 65, 66, 99, I02, I 29, I30, I33, I47, I 5 I, I 55-156

Psyche, 2I-24, I63, I64

$\mathrm{R}$

Rembrandt, 132

Rameses, 200-202

Remus, 67

Rhea, 48

Rizzo, Antonio, 122, 123

Robbia, Della, I I2, I 13

Rodin, Auguste, 21, I47, I66, I 72-173

Romulus, 67-68, 74

Rude, I64

S

Samothrace, I44-I45

Sansovino, I 18, 119

Satyr, see Faun

Scarab, 201

Scopas, 49, 61 , 66, 73, 85, 88, 190, I91

Selene, 66, 136, 182

Semele, 29

Silenos, 68-69, 130-131, I55-156

Socrates, 68

Sophocles, 83, 84, 154 


\section{INDEX}

$\mathrm{T}$

Thauricus, 34

Theseus, $55, \mathrm{I} 83$

Thetis, 25, 192

Thorwaldsen, 125, 127

Thothmes, 198-200

Tiberius, 54, 69

Titus, 55, 80-82

Torrigiani, 103

Trojan, 25, 54, 57, I25, I 55

Vasari, I05

Venus, see Aphrodite

Verrocchio, I13-I14, I17-118

Virgil, 67

Voltaire, 166

Volterra, 103

Vulcan, I8I

W

Winged Lion, 120, I2I

Wolf, 67

$\mathrm{X}$

Xerxes, 39, 40

\section{Z}

Zephyr, 22, 23

Zeus, 24, 27, 29, 32, 33, 34, 43, 47-49, 54, 71, 74, 75, 93, I34, I35, I8I, I92 
THIS BOOK IS DUE ON THE LAST DATE STAMPED BELOW

AN INITIAL FINE OF 25 CENTS WILL BE ASSESSED FOR FAILURE TO RETURN WIL BOOK ON THE DATE DUE. THE PENALTY WILL INCREASE TO 50 CENTS ON THE FOURTH DAY AND TO \$1.00 ON THE SEVENTH DAY
OVERDUE.

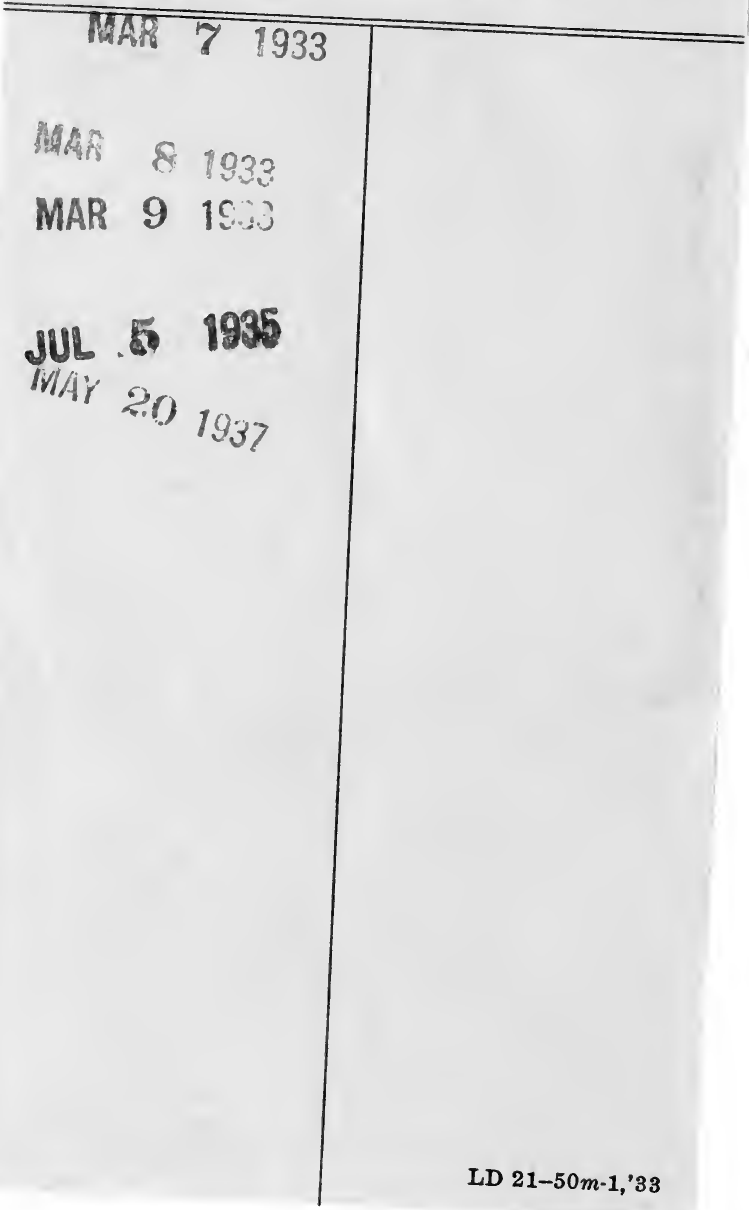


C116908

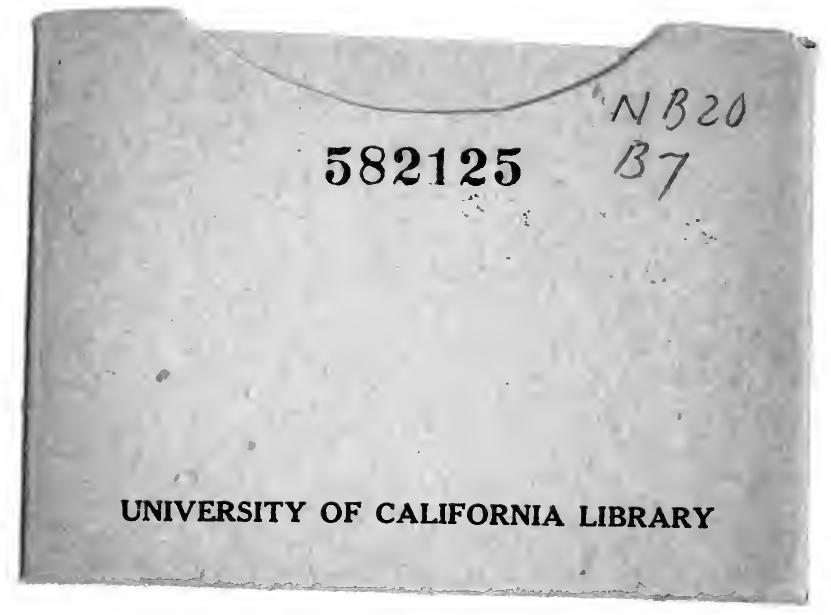


